Historic, Archive Document

Do not assume content reflects current scientific knowledge, policies, or practices. 


\section{Spring-Flowering Bulbs}

All bulbs, such as Hyacinths, Tnlips, Narcissus, Crocus, etc., shoull the beginners who often confuse the terms "Spring-Flowering," with "Spring-Planting, and order too late. How to Order Please use order sheets found in front part of every catalogue, earefully filling $\underline{\text { }}$ ont blank spaces at top for shipping direvtions. lie sure to sign your name and give postofice and state. To avoid mistakes do not write letters on sane sheet as orders.

Remittances shoull be male by P. O. or bxpress money order, bank draft or registered letter. Remitcances Remittances in any other way are entirely at sender's risk.

We Pay Postage Prices quoted in this Catalogue (except where noterl) are for goods leliverel

Express Preferable 11 e do not prepay express shipments, but reduce price of goods to customer
insteat. Where distance is not too great it is best to order by express; at your Post Office postpaid. stronger stork in better condition can be sent, and if goods are miscarried or damaged, they can be more casily traced and damage rectified.

Extras are always added in proportion to size of order; except on prices at dozen and hunilreil rates, We Guarantee that all Bulbs, Plants, Seeds and other gogds shall reach our customers safely ani states and territories to obtain choice bulbs and plants as if they could call at our nurseries in person.

\section{THE STORRS \& HARRISON CO., Painesville, Ohio.}

\section{BULBOUS PLANTS A FEW HINTS oN}

Treatment of Bulbs in Pots. For early flowers most bulbs should be potted in September, and for a succession of flowers, at intervals up to December. A very good soil for the growth of bulbs is composed of one-half decomposed turfy loam, and the remainder equal parts of well-rotted manure and leafmold well mixed together. The size of the pots used depends on size of bulbs and effects desired. For a single Hyacinth, a 5-inch pot should be used; for Tulips, a 4-inch pet would be large enough. Nareissus require about the same size pot as IIyacinth. In potting, fill the pots to the rim with soil, press the bulbs into it until they are covered, then press down the soil around the sides of the pot, give a good watering which will further settle the soil. The pots should now be placed in a cool, dark situation, so as to encourage a stroug growth of roots before the bulbs start at the top. A very good place is a cool cellar where the pots should be covered with 5 or 6 inches of sand, or a trench may be dug in the open ground, and the pots placed in it and covered with 6 or 8 inches of soil; then cover over that with sufficient leaves or coarse manure to keep out frost, so they may be removed when wanted. In six or eight weeks they will liave malle snfficient root to admit of their being brought to the light; as they begin to grow, water freely, so that the soil may be moistened to the bottom of the pots. By bringing in a few at intervals of eight or ten days, a succession of flowers may be had for months.

Hyacinths in Glasses. Grown in this way Hyacinths are fine oruaments for the sitting-room or parlor, and can be grown with very little trouble. Fill the glasses with water so that the base of the bulbs will just tonch it; set them away in a cool, dark cellar or closet until the roots have reached the bottom of the glasses, when they may be brought to the light. When brought into the house they should be kept near the light and at a temperature of between 50 and 60 degrees.

Out-Door Planting. May be done any time from the last of September to the first of January, where the ground remains unfrozen, but, if possible, should be lone in October or early November.

Soil. Any good, thoroughly drained soil will grow bulls well. If it should be a heavy elay it would he best to add sand and well-rotted manure to make it loose. The surface of beds slould be slightly raised at center so that water will run off quickly, as bulbs are liable to rot if water remains on them any length of time.

Winter Protection. After the ground is frozen, eover the beds with 4 or 6 inches of leaves, if they ean be had; if not, coarse manure will do nearly as well; if leaves are used, throw over a little brnsh or earth, to prevent blowing off. In the South, where the ground does not freeze more. than a slight erust, they will require no protection.

Care of Tulips and Hyacinths after Flowering. Nhont a month after they are through flowering, or when the tops appear yellow or decayed, they should be taken up and the tops eut off within an inch of the bulbs, but leave the roots on, spread them in dry, airy room for ten or twelve days to dry, after

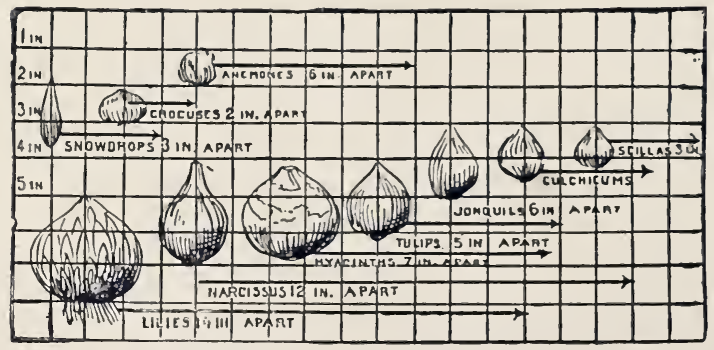
which wap them in paper, or pack them in perfectly dry sand, and store iu a dry, cool place until wanted for planting. If the beds in whicl they have been blooming are wanted for bediling plants, they may be taken up as soon as they are through flowering and leeled in the gromnd in some out-ofthe-way place with the tops on until they ripen, theu treat them the same way as if they had ripened in the bed.

Depths and Distances for Planting. The rows should be 6 to 12 inches aprart and the bulbs 4 to 8 , aecorling to size of bulb. See cut. 
PLEASE TAKE THIS OUT AND USE IN ORDERING. ADDRESS:

\section{The Storrs \& Harrison Company,}

PAINESVILLE, LAKE COUNTY, OHIO.

D. All remittances by Post-Office or Express Order, Bank Draft and Registered Letter are at our risk. Do not send Money in ordinary letters without registering; it is not safe; we will not be responsible for it; and if lost you must not expect us to make it up. But when sent as directed, an extra plant or bulb will be given to cover cost of $P$. O. Order or Registering, if order amounts to $\$ 1.00$ or more.

Your Name

Post-0ffice -

Express Office (if to be sent by Express)

County of

State of

Date.

Amount Enclosed, \$ 
Please write below the names and address of a tew buyers of Trees, Plants, etc. 


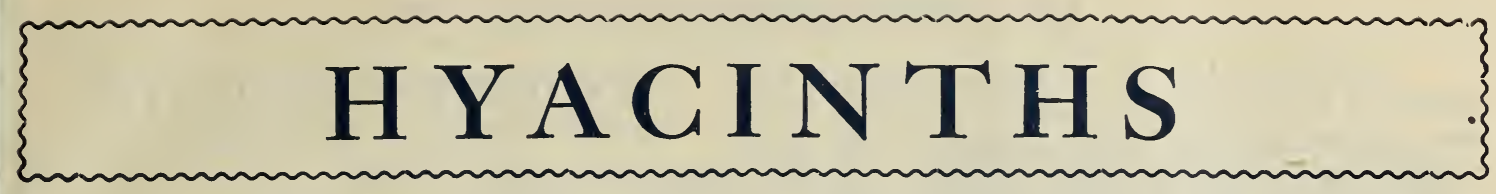

\section{CHOICE NAMED DUTCH HYACINTHS}

The large-flowered Dutch Hyacinths are indispensable for Winter forcing; their exquisite coloring and perfume commanding a degree of popular faror accredited to no other winter flowering bulb.

Started in pots or glasses and lept in the cool dark (see cultural directions inside front cover), they remain dormant indefinitely, but yield readily to forcing treatment; so that one may direct a succession of bloom, at will, throughout the season.

The named varieties as given below, while more expensive than the unnamed sorts, are larger and best adapted to this purpose, and come true to the color description you may select. A predominance of single varieties will prove most satisfactory.

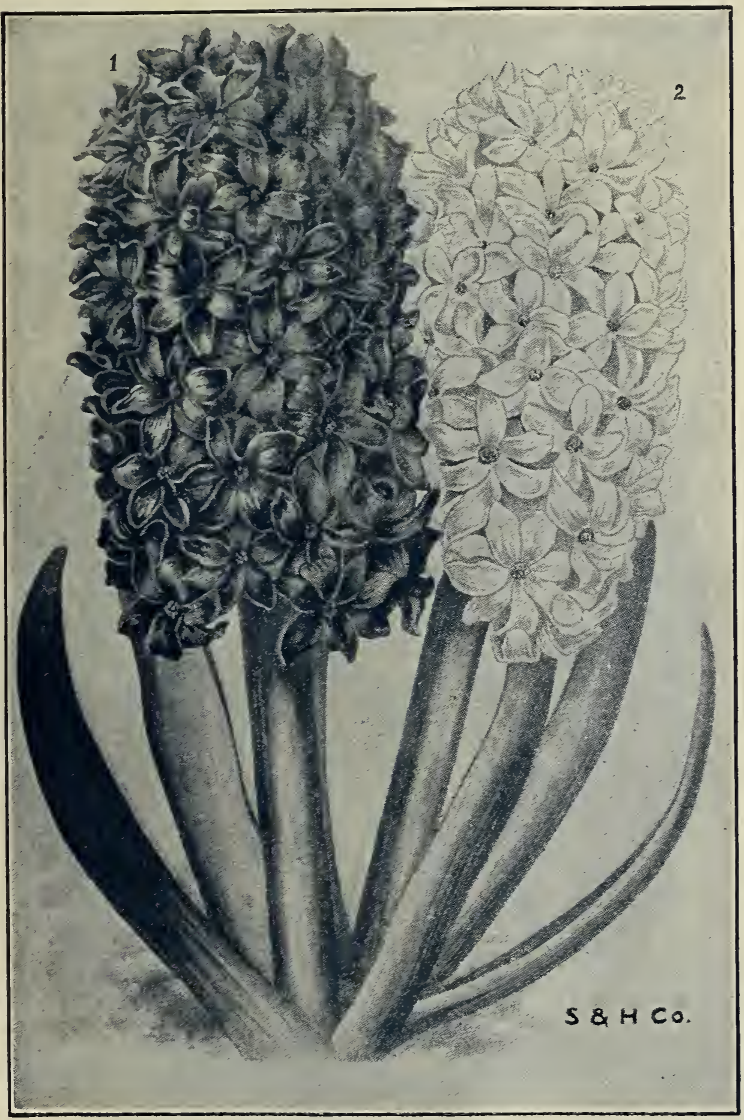

\section{SINGLE SINGLE RED AND ROSE.}

Each

Baron von Thuyll-Early, flesh pink.... 10c Cardinal Wiseman-Light rosy pink, large truss ................... 12c Fabiola-Pink, carmin€ striped, extra.... 10c Gen. Pelissier-Dark red, very early.... 10c Gertrude-Deep pink, fine large truss.... 10c Gigantea-Deep pink, large spikes...... 10c Incomparable-Scarlet, extra fine...... 12c Moreno-Bright pink .............. 10c Mr. Stanley-A splendid dark red...... 12c Prima Donna-Extra; dark red........ 15c Robert Steiger-Deep red ...........10c
Each Doz. Roi des Bélges-Fine, glossy dark red(No.1)10c 100 Rosea Maxima-Rose blush, broad spike,

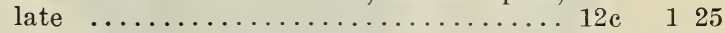
Veronica-Deep red ...............10c 100

SINGLE BLUE (of various shades).

Each Doz. pact spike .................. 10c \$1 00 Grand Maitre-Deep porcelain blue, large spike ....................... 10 100 Johan-New; light blue .............. 12c 125 King of the Blues-Dark, extra good....10c 100 La Peyrouse-Light blue, shaded lilac.... 10c 100 Pieneman-Pretty light blue..........10c 100

Prince of Wales-Dark blue shaded violet, white-eyed; distinct ................ 12c 125 Regulus-Light blue, large spike.......10c 100 William III-Very dark blue ........ 10c 100

SINGLE YELLOW (of various shades).

Each Doz.

Anna Carolina-Deep yellow .......... 10c $\$ 100$

Gen. Gordon-Pure yellow ........... 12c 125

Ida_Golden yellow, fine large spike.....10c 100

King of Yellows-Bright, extra large bell and spike (No. 2)............... 15c 150

Obelisque-Pure yellow, large truss...... 12e 125

SINGLE WHITE (of various shades).

Each Doz.

Baron von Thuyll-Pure white ........ 10c \$1 00

Blanchard-Pure white, very early ..... 10e 100

Blancheur a'Merveille-Broad truss, pure

white ....................... 12c 125

Grand Vedette-Snow white, very early.. 12c 125

La Franchise-Rosy white ...........10 100

La Grandesse-Pure white, very large spike $12 \mathrm{c} \quad 125$

L'Innocence-Pure waxy white, fine spike 12c 125

Mad. van der Hoop-Waxy white, fine truss 10c 100

If ordered by express, deduct 20c per dozen.

100 Lord Wellington-Pink, fine large bell .. 10e

\section{DOUBLE} DOUBLE RED AND ROSE.

Boquet Royal-Rosy salmon ............12e \$1 25 Boquet Tendre-Dark red, very early ... 10c 100 Czar Nicholas-Delicate rose, early ..... 10e 100 Grootvorst-Deep pink .............10e 100 100 
Each Doz. Nable Par Merite-Deep red, large flowers. 10e $\$ 100$ Pres. Roosevelt-Extra fine, deep rose... 12e Prince of Orange-Deep pink, large truss. 10c Princess Louise-Dark red ........... 12e Regina Victoria-Dark rose, early, very

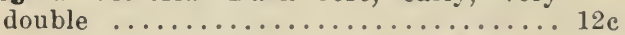

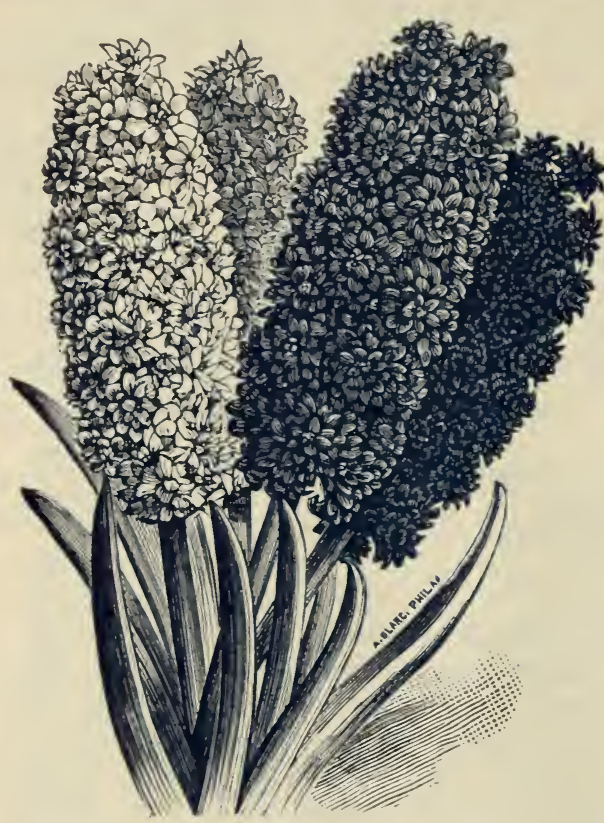

DOUBLE BLUE (of various shades).

Bloksberg-Porcelain, fine large truss... Each Garrick-Azure blue, large spike, early... 10c General Antinck - Violet blue, deeper center .......................

Prince of Saxen-Weimar - Dark, semidouble, long spike .............. 15c

Rembrandt-Large floret and spikes, rich deep blue ...................... 12c

Van Speyck-Deep blue, very large compact truss .................... 12

DOUBLE YELLOW (of various shades). Boquet $D$ 'Orange-Orange salmon ..... Each Gen. Gordon-Purest yellow ........ 12c Goethe-Light yellow ............ 10c Sunflower-Pure yellow ........... 12c

DOUBLE WHITE (of various shades).

Each

Duchess de Bedford-Pure white....... 10e Flevo-White, tinged yellow ......... 10 e Isabelle-Tinted white, full bells, large spike ...................... 12e

La Tour D'Auvergne - Pure white, very early .......................

La Virginite-Blush white, fine large bells. 10e Non Plus Ultra-Pure white, deep violet

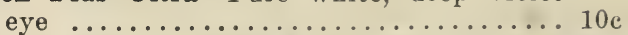
Prince of Waterloo-Pure white, very fine. 10e If ordered by express, deduct $20 \mathrm{c}$ per dozen.

Our choice of above named Double Hyacinths by express, $\$ 5.50$ per 100 .

100

125

Doz.

$\$ 100$

100

125

100

\section{EXHIBITION HYACINTHS}

(For Pots or Glasses.)

100 Baroness von Thuyll-White.

125 Chas. Dickens-Blue.

Gertrude-Pink.

125 Gigantea-Deep rose.

L'Innocence-Large white.

Robert Steiger-Red.

Johan-Light blue.

Rosea Maxima-Double pink.

La Grandesse-Pure white, double.

La Virginite-Blush white, double.

Prince of Orange-Doubie rose.

Bloksberg-Double, deep blue.

The set of 12 for $80 \mathrm{c}$; any 6 for $45 \mathrm{c}$.

\section{ROMAN HYACINTHS}

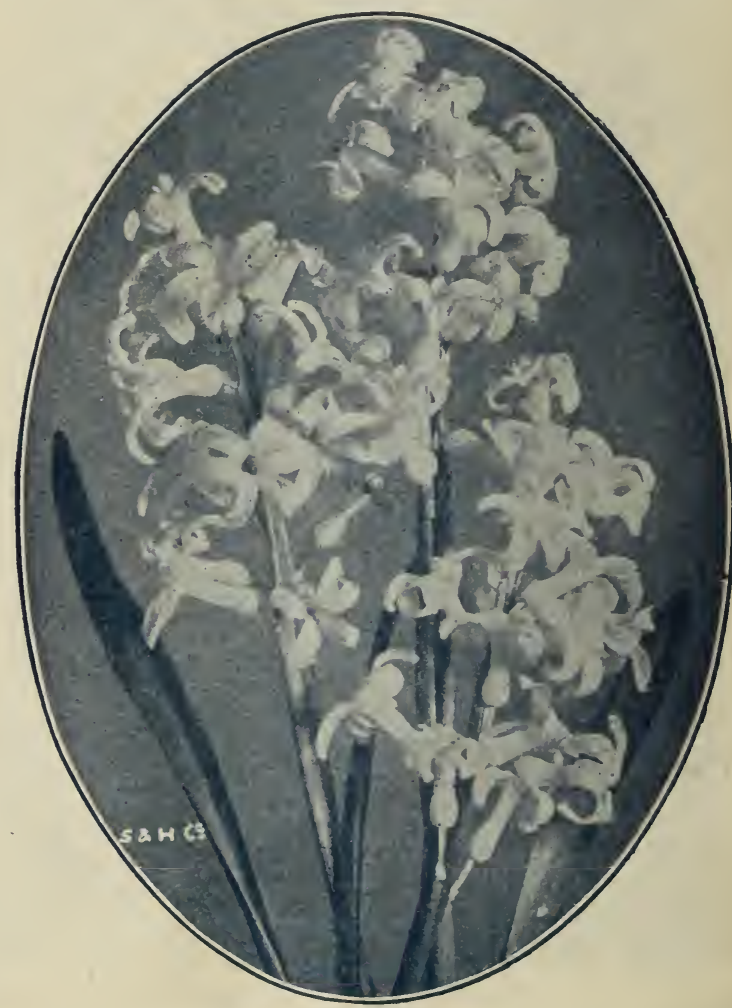

Early Roman White-5 cents each; 50 cents per dozen; $\$ 4.00$ per 100 ; by express, $\$ 3.50$ per 100 .

Single Blue Roman-5c each; 40 e per dozen.

Double Rose Roman-5c each; 40 c per dozen. 


\section{MINIATURE or DUTCH ROMAN HYACINTHS}

Beautiful, small sized replicas of the Dutch Hyacinths; especially suitable for pots, pans and boxes. They closely follow the French Romans in blooming season, comparing well in size and freedom, and thus making a good succession for that type. The following varieties are all single:

Baroness von Thuyll-Pure white.

Charles Dickens-Light blue.

Czar Feter-Finest light blue.

Gigantea-Blush pink.

Ia Grandesse-Best pure white.

L'Innocence-Pure white.

Ia Peyrouse-Clear porcelain blue.

4c each, 40c per dozen; by express, \$2.50 per 100.

\section{GRAPE HYACINTHS}

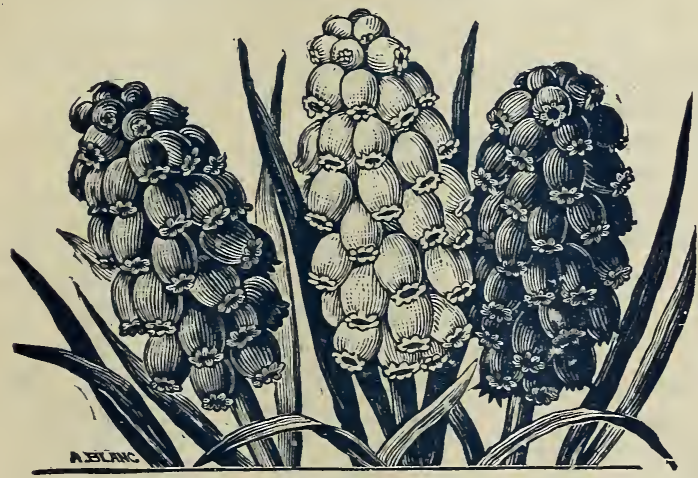

A beautiful class of hard $J$ bulbs, producing flower spikes about 6 inches high, with small round bells so arranged as to resemble a bunch of grapes. They are perfectly hardy and increase very rapidly, making excellent plants for permanent edgings or for groupings on the lawn, where they may remain many years without being disturbed.

Each Doz.

Blue Grape. ..................... 3c 15c

White Grape .................. $3 \mathrm{c} \quad 20 \mathrm{c}$

\section{FEATHERED HYACINTHS}

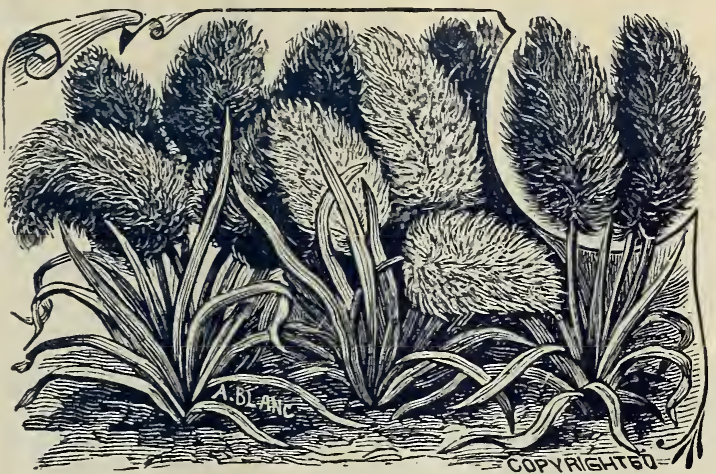

An interesting species, blooming in feathery plumes on long stalks. Perfectly hardy, particularly adapted for outdoor planting. Each, 3c; dozen, 25c.

\section{HYAGINTHS IN SEPARATE COLORS}

Anyone who has seen Hyacinths blooming in outdoor beds of generous proportions, can not fail to appreciate their value for putting color and fragrance into the spring lawn.

For large bedding plans, the cost of the named varieties might seem prohibitive; but the following offer of unnamed sorts separated accurately into seven distinct colors, provides a splendid assortment of large, free-blooming bulbs at special bedding prices:

Single.
Dark red.
Rose and pink.
Pure white.
Blush white.
Dark blue.
Light blue.
Yellow.

\section{Double.}

\section{Dark red.}

Rose and pink.

Pure white.

Blush white.

Dark blue.

Light blue.

Yellow.

Each, 5c; 50c per dozen.

Six sold at dozen rates; 25 at 100 rates. If ordered by express, 40c per dozen: $\$ 3.00$ per 100 .

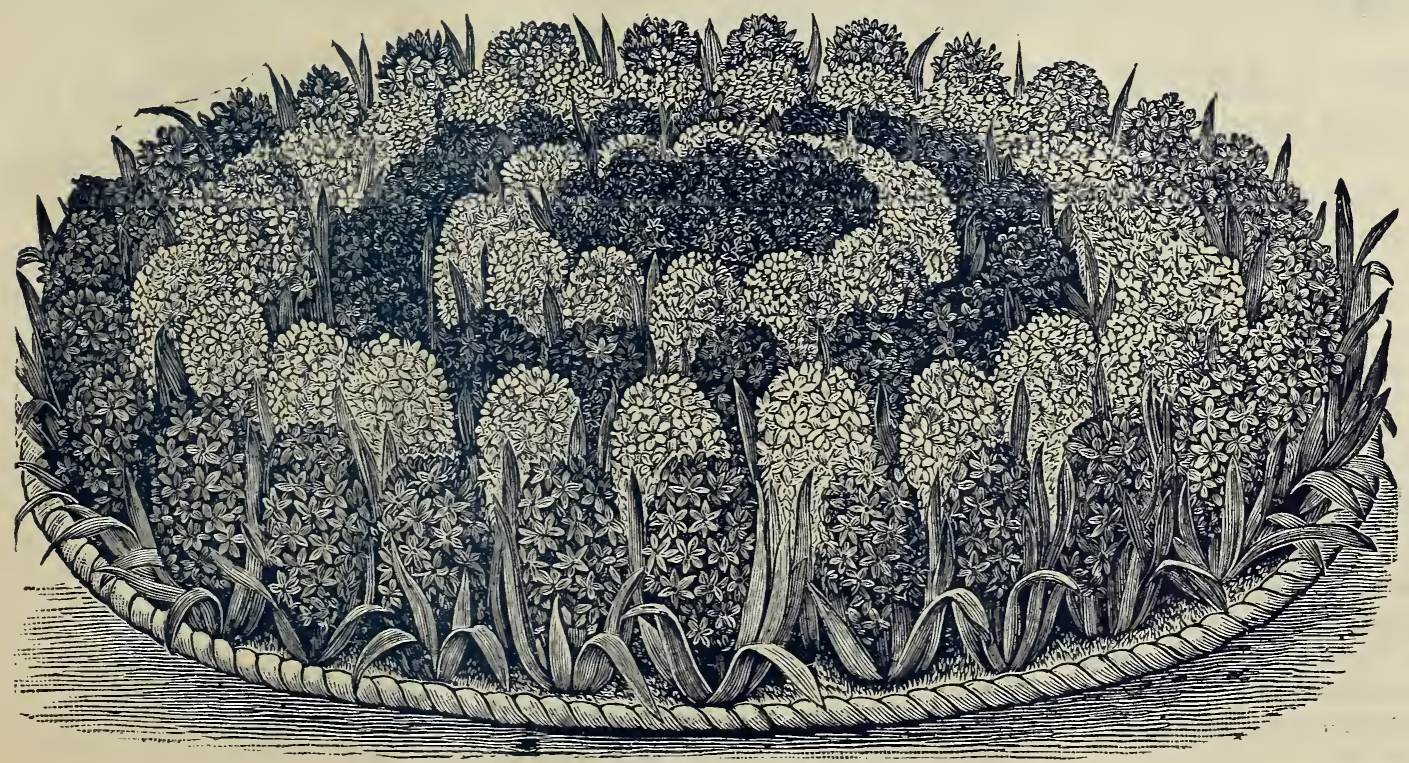




\section{T U L I P S}

Nothing that grows in the lawn or garden is eapable of such gorgeous color display as the spring flowering Tulips. Individually, their graceful contour is charming, and their varied shades and markings boldly handsome. P'otterl specimens of three or more to a pot make very striking house decorations and as such are largely used; but their brilliancy and splendor appear to fullest value when massed in generous beds or borders, and given the greensward of the outdoors for a setting.

For outside flowering the Tulip should be planted during Octoher or November. Plant three to four inches deep in rows six inches apart. Allow the ground to freeze before putting on their winter covering, which should be the same as that recommended for Hyacinths. They may remain in the berls for two or three years, when they should be taken lip and separated.

For pot culture give same treatment as Hyacinths.

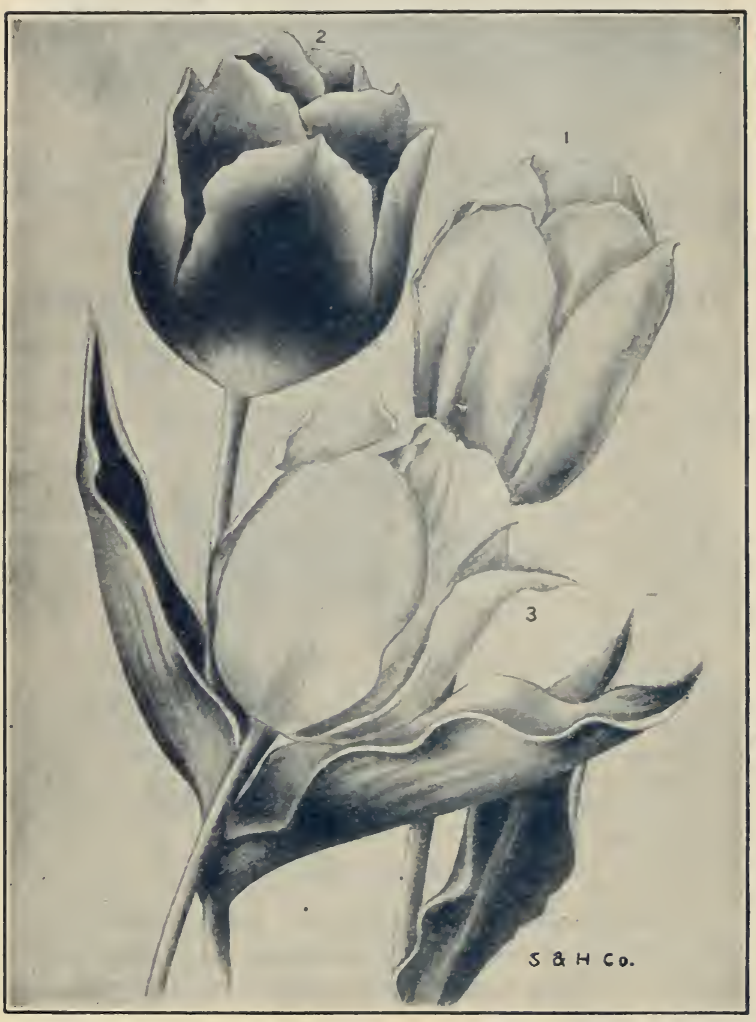

\section{BEST EARLY SINGLE TULIPS} FOR FORGING AND BEDDING

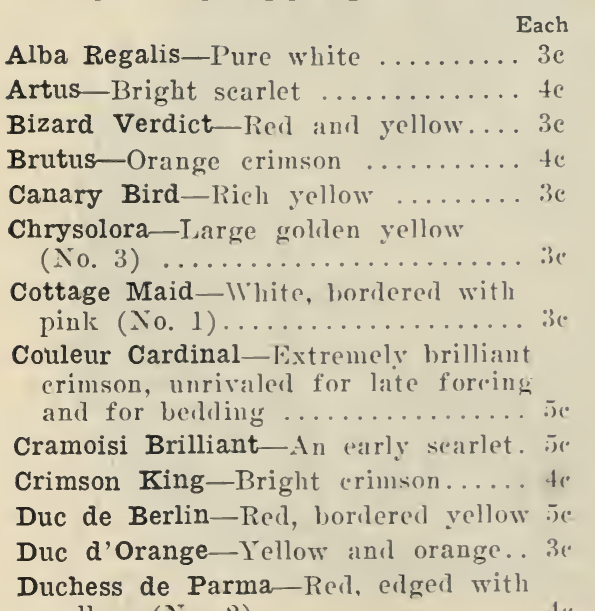

2.) $\$ 150$

$30 \mathrm{c} 200$

25e 150

$30 \mathrm{e} \quad 200$

$30 \mathrm{c} \quad 150$
Duc Von Tholl-Crimson

Each Doz. 100 Gold striped ........3c

Rose

Scarlet

Vermilion

White

Yellow

Joost van Vondel-Red and white... 4c

Kaiserkroon-Red and yellow....... te

La Belle Alliance-Scarlet ........ tc

La Reine-White, shaded rose...... 3e

L'Immaculee-White, extra fine.... . 3c

Mon. Tresor-Rich yellow, extra large $4 \mathrm{c}$

Pottebaker-White

Yellow, clear yellow.... te

Scarlet ............. je

Proserpine-Glossy crimson pinl.... jc

Purple Crown-Purplish red ...... 4c

Rachel Ruisch-Rosy pink........ 3e

Rosa Mundi-White, shaded and

edged deep rose ................ 3e $25 \mathrm{c} \quad 150$

Rose Gris de Lin-Rose, very fine... 4e 35 c 200

Rose Luisante-Very deep rose..... бе 45 с 300

Silver Standard-White, feathered

with erimson ................ 4c 35e 200

Van Gooyen-Rose ............ 4e 35e 200

White Hawk-One of the best whites. $5 \mathrm{c}$ 40e 275

White Swan-White ............ 3e 25e 150

Wouverman - Violet, extra large

flower ....................... 4e 40e 2 i.

Yellow Prince-Yellow, extra fine... 3e 25e 150

If ordered by express at 100 rates, deduct $25 \mathrm{c}$ per $100 ; 6$ at dozen rates; 25 at 100 rates.

\section{LATE or MAY-FLOWERING SINGLE TULIPS}

$2 . \bar{x} \quad 150$

$3010 \quad 1 \quad 50$

40 c. 250

40c 250

30 c 200

40. 250

3)e 150

175
An interesting group, distinct in many ways from the preceding list of early flowering Tulips, their blooming period commencing a week or two after the others cease. Bold, strong and hardy-they are naturally adapted to permanent outdoor plantings and, hesides making their brilliant field show from year to year, yield the finest cut flowers of any class. It is advisable to plant a trifle deeper than the earlier sorts. ground with erimson, red or white markings ................. $3 e$ 25e $\$ 150$ Bouton D'Or (Ida)-Very rich and deep golden yellow. One of the Byblooms-Mixed varieties. P'urple, lilac, or black markings on white ground .................... 3e 30 175
Bizarres-Mixed varieties. Yellow Each Doz. 100 finest late flowering Tulips........ te $30 \mathrm{c} \quad 175$ 
Gesneriana Macrospila-One of the Each 100 most distiuct and showy of the Gesneriana type. A bright glowing crimson, with deep zone of black and yellow. Delightfully fragrant. 3

Gesneriana Spathulata - Brightest scarlet, with purplish center. Like all of this class, flowers are large and stems extra long and strong.. $4 c$

Golden Crown-Golden yellow, edged

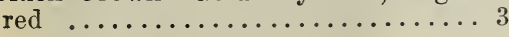

Isabella (Blushing Bride)-Carmine rose, shaded with eream and suffused silvery white and rose. Very beautiful ................ 4c

La Merveille - Scarlet, suffused orange ................4 4c 35e 200

Parisian White-Choice white .....5 5e 50c 250

Parisian Yellow - Very fine, pure yellow ................. 5c 50 2.50

Picotee (Maiden's Blush)-Rosy pink, shaded white ...............4 4c 35c 200 If ordered by express, deduct 25c per 100.

\section{DARWIN TULIPS}

This section of the May-flowering group is rapidly gaining prominence. They are very strong growers, attaining a height of 24 to 30 inches; with large globular flowers of perfect shape, heavy texture and rich coloring.

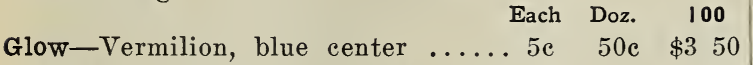

Gretchen-Extra fine; delicate blush with interior of soft rose ....... 5c

Kate Greenaway-White, tinged lilac. 5c

Painted Lady-Milk white; stems dark 5e

Pride of Haarlem-Enormous flowers of brilliant crimson............5c

Wedding Veil-Silvery white, shaded lilac ................... 5 c

Darwin Mixed - Including almost every conceivable color and shade from the most delicate blue to the darkest violet, from soft rose to the most brilliant red, and from light brown to deep black .......... 4c

\section{PARROT TULIPS}

These belong to the late or May flowering class, and are noted for their immense showy flowers, with beautifully fringed or cut petals of brilliant and varied colors.

Each Doz. 100

Coleur Cafe-Brown ............. 3e 30 200

Gloriosa-Striped $\ldots \ldots \ldots \ldots \ldots \ldots .3 \mathrm{c} \quad 30 \mathrm{c} \quad 200$

Perfecta-Yellow and scarlet ...... 3e 30e 200

Mixture of above sorts.......... 3 c 20c 125

\section{Single TUlips in SEPARATE Golors}

Our specially selected strain. Nothing could be more attractive than a bed all red, all rose, all pink, all white, etc.

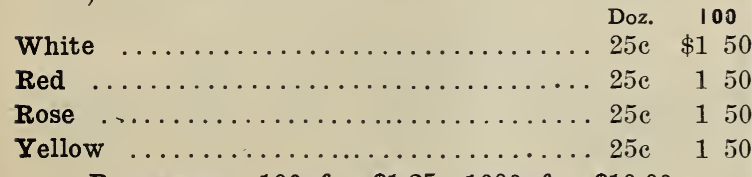

By express, 100 for $\$ 1.25 ; 1000$ for $\$ 10.00$.

50

50

\section{DOUBLE TULIPS}

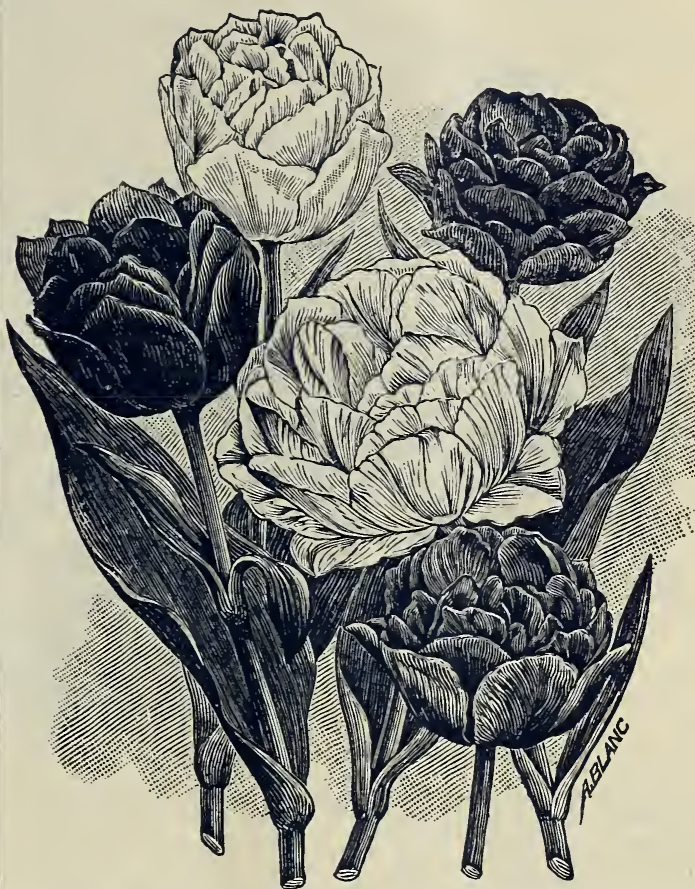

The double Tulips are outclassed by the single varieties in the matter of brilliancy, but their blooming season is longer and the flowers of greater substance. 00 The late sorts are very valuable for bedding, but are not adapted to forcing. EARLY Each Doz. . 100

Curonne d'Or-Golden yellow......

Crown of Roses - Rich rose, shaded

white ................. 7 c 60 400

Duke of York - Carmine, bordered white $\ldots \ldots \ldots \ldots \ldots \ldots \ldots \ldots 4$ e $30 \mathrm{e} \quad 175$

Gloria Solis - Bronze crimson, bor dered yellow .............4 4c 35e ${ }^{-2} 00$ Imperator Rubrorum-Scarlet .....5e $45 \mathrm{c} \quad 300$ Le Blason-Rose and white.......4c 35e 200 La Candeur-White; a fine bedder...4 4e $30 \mathrm{c} \quad 175$ Murillo-Favorite pink, extra .....4 4c $35 \mathrm{c} \quad 225$ Prince of Wales - Purplish scarlet, large and distinct ...........4 4e 40 275 Purple Crown-Very dark purple... 4c 35 c 225 Rex Rubrorum-Scarlet ........4 4c 35c 225 Rose Blanche-Pure white ....... 3e 30e 200 Rosine-Fine, dark rose-pink......4c 40 250 Rubra Maxima-Large scarlet ..... 4e 35e 250 Salvator Rosa - Deep rose, flamed 5 e $45 \mathrm{c} 300$ Titian-Reddish brown and yellow..4c 35e 225 Tournesoll-Red and yellow ......4 4c 35c 225 Tournesoll-Yellow ...........4e 35e 225

Blanc Bordre Poupre - Violet, bor-

dered white ..............4 4c 30 $\$ 200$ Blue Flag-Purplish violet .......5 5e 45c 300 Count of Leicester-Golden yellow...4c $30 \mathrm{c} \quad 200$ Yellow Rose-Pure yellow........ 3c 30 200 If ordered by express at 100 rates, deduct $25 \mathrm{c}$ per $100 ; 6$ at dozen rates; 25 at 100 rates. 


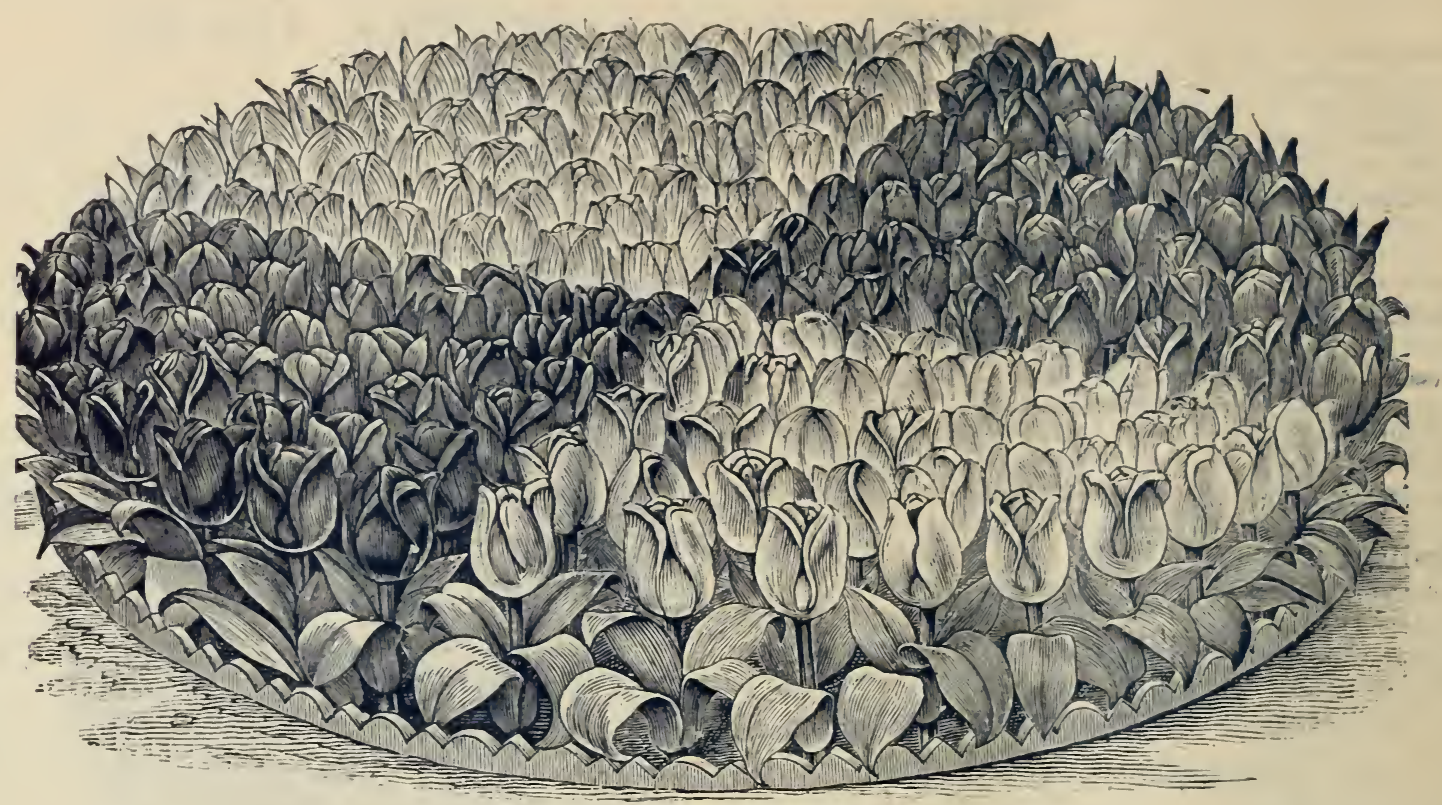

CIRCULAR BED SIX FEET IN DIAMETER, REQUIRING 200 BULBS.

DOUBLE TULIPS in SEPARATE COLORS

Very effective when bedded in solid colors. Specially selected for quality.

White

Red

Rose

Yellow

By express, 100 for $\$ 1.25 ; 1000$ for $\$ 11.00$.

\section{EXTRA CHOICE MIXED TULIPS}

These are superb qualities, mixture of the named sorts, and where it is not important to have the colors separate, will give the best of satisfaction.

Mixed Single, Early Varieties-20c per doz.; $\$ 1.25$ per 100 ; by express, $\$ 1.00$ per 100 ; per $1000, \$ 8.50$.

Mixed Single, Late Varieties-25c per doz.; \$1.75 per 100 ; by express, $\$ 1.50$ per 100 .

Mixed Double, Early Varieties-20e per doz.; $\$ 1.50$ per 100 ; by express, $\$ 1.25$ per 100 ; per $1000, \$ 9.50$.

Mixed Double, Late Varieties-25c per doz.; $\$ 1.50$ per 100 ; by express, $\$ 1.25$ per 100 .

\section{OUR PEERLESS COMBINATIONS FOR GIRGULAR BEDS}

Our Special Bedding Tulips, both in named varieties and named colors, are used in immense quantities in public parks and on private estates. The named colors, while not quite so effective as the more expensive named varieties, are nevertheless very showy, and cost but little more than the "cheap mixtures."

The following combinations are for a circular bed 6 feet in diameter, requiring 200 bulbs:

\section{Combination No. 1-Single Tulips} Section 1-50 La Belle Alliance-Scarlet. Section 2-50 Chrysolora-Golden yellow. Section 3-50 La Belle Alliance-Scarlet. Section 4-50 Chrysolora-Golden yellow.

The 200 by mail, $\$ 4.00$; by express, $\$ 3.50$.

\section{Combination No. 2-Single Tulips}

Section 1-50 L'Immaculee-White.

Section 2-50 La Belle Alliance-Scarlet.

Section 3-50 Chrysolora-Yellow.

Section 4-50 Cottage Maid-White and pink.

The 200 by mail, $\$ 3.40$; by express, $\$ 2.90$.

\section{Combination No. 3 -Single Tulips}

Section 1-50 L'Immaculee- White.

Section 2-50 Crimson King-Crimson.

Section 3-50 L'Immaculee-White.

Section 4-50 Crimson King-Crimson.

The 200 by mail, $\$ 3.25$; by express, $\$ 2.75$.

\section{Combination No. 4}

200 Unnamed Single Tulips, in any desired combination,-all one color or all colors, in white, pink, red and yellow.

By mail, $\$ 2.75$; by express, $\$ 2.25$.

\section{GIRCULAR BED OF DOUBLE TULIPS}

The following two combinations are peerless for bright showy beds, are simple in construction, and the cost is reasonable. 200 bulbs are required, making an attractive circle 6 feet in diameter.

\section{Combination No. 5-Double Tulips}

Section 1-50 La Candeur-White.

Section 2-50 Rex Rubrorum-Scarlet.

Section 3-50 La Candeur-White.

Section 4-50 Rex Rubrorum-Scarlet.

The 200 by mail, $\$ 3.75$; by express, $\$ 3.25$.

\section{Combination No. 6}

200 Unnamed Double Tulips, in any desired combina. tion,-all one color or all colors, in white, pink, red and yellow.

By mail, $\$ 2.75$; by express, $\$ 2.25$. 


\section{NARGISSUS or "DAFFODILS"}

Of all bulbous plants the Daffodils will stand more vicissitude of soil and climatic conditions than any other class. All they need is a good start to make themselves naturally and gloriously "at home", in any desired situation. Their delicate scented flowers are very welcome in the winter pots and boxes; but outof-doors in garden, lawn or wildwood, they find their greatest perfection.

Some of the Narcissi bloom as early as the Crocus, making the garden look very cheery and bright with their gold-color in spring. The flowers assume many forms and present many charming combinations of white, gold, primrose, orange, sulphur and pure yellow. Some are quite fragrant; all are very hardy, except the clustered Polyanthus varieties.

(100 rate by express only.)

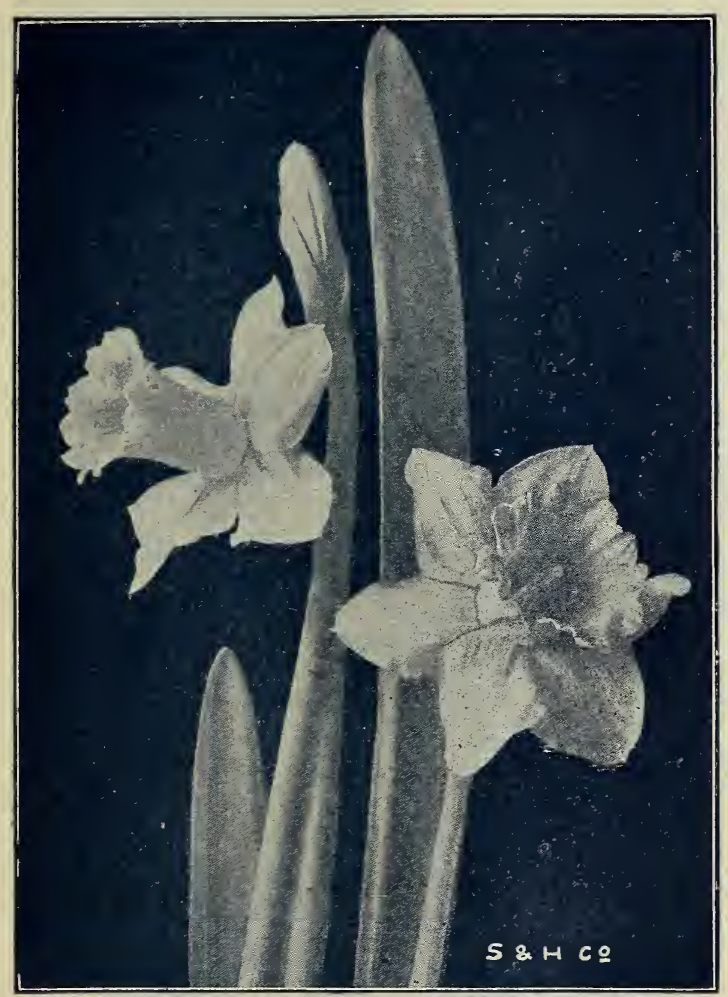

NARCISSUS TRUMPET MAJOR.

\section{SINGLE HARDY NARGISSUS}

\section{Large Trumpet Sorts.}

Bulbocodium "Hoop Petticoat" -Exceedingly pretty flowers, rich gold. en yellow ...................

Bulbocodium Citrinus - The large sulphur-colored "Hoop Petticoat".6c

Emperor - Magnificent, all yellow flowers with immense trumpet and over-lapping petals measuring 3 to $3 \frac{1}{2}$ inches across. One of the finest Daffodils for cutting (No. 4) ....6 6e

Empress-Large, bold and erect. Perianth white, trumpet rich yellow. An accredited leader among the bicolored trumpets ..........6c

Golden Spur-Extra large, bold, rich yellow flowers, early and extremely free flowering (No. 2).......... 5c

Princeps-Deep yellow trumpet, sulphur white outside, extra large.... 3e

Trumpet Major-A valuable early foreing variety, deep golden yellow $3 e$
Victoria-A new introduction in pure whites. Extra large flowers, fragrant-a winner (No. 3).......66 6e 60e 350 If ordered by express at dozen rates, deduct $10 \mathrm{c}$ per dozen.

\section{Medium Trumpet Sorts.}

Mrs. Langtry-A remarkably freeflowering variety with broad white perianth and large white cup, edged bright yellow ............... 3c 30 125

Sir Watkin-Perianth butter yellow, deep golden cup (No. 5).......5 5c 50 250

Stella-A beautiful white star-shaped flower with distinct yellow trumpet. $3 c \quad 30 \mathrm{c} \quad 125$

\section{Short Trumpet Sorts.}

Each Doz. 100

Biflorus (Two-flowered Poeticus) white, with yellow cup.......... 3c $30 \mathrm{c} \quad 125$

Jonquil Campernelles-Large, single light yellow, very fragrant.......3c 25c 125

Jonquil Rugulosus (The Giant Jonquil)-Large deep yellow flower with wrinkled cup............. 3c 25e 125

Jonquil Double Yellow ..........4c 35c 175

Jonquil Single Yellow ........... 2c 15c 100

Poeticus (Pheasant's Eye)-Fragrant pure white flower, with small yellow cup distinctly edged scarlet. $3 \mathrm{c} \quad 25 \mathrm{c} \quad 100$

Poeticus Ornatus-Large, beautifully formed, pure white flower, with saffron cup tinged with rosy scarlet. 3e $30 \mathrm{c} \quad 125$ If ordered by express at dozen rates, deduct $5 c$ per dozen.

\section{POL YANTHUS NARGISSUS}

Beautiful, free-flowering, deliciously sweet-scented flowers of easiest culture; suitable for forcing or for garden decoration. They bear tall spikes of bloom, with from 6 to 20 flowers each. Bulbs planted in the open border in October and November stand the winter with slight protection.

Each Doz. flowers, with primrose-colored cups..... 8c $70 \mathrm{c}$

Grand Monarque-Large white flowers with lemon-yellow eup ............... 8c 70c

Grand Primo-Pure white, eup eitron.....8 $8 \mathrm{c} \quad 70 \mathrm{c}$

$50 \mathrm{c} 300 \quad$ Grand Solie D'Or-Rich yellow with reddish orange cup ................... 8c $70 \mathrm{c}$

50c 300 Paper White, Large Flowered (Grandiflora) -A variety of strong growth, and an early bloomer; flowers and truss very large; pure white; can be had in bloom at Christmas. Per $100, \$ 1.50 \ldots \ldots \ldots \ldots \ldots \ldots \ldots \ldots \ldots .4 \mathrm{c} \quad 40 \mathrm{c}$ 


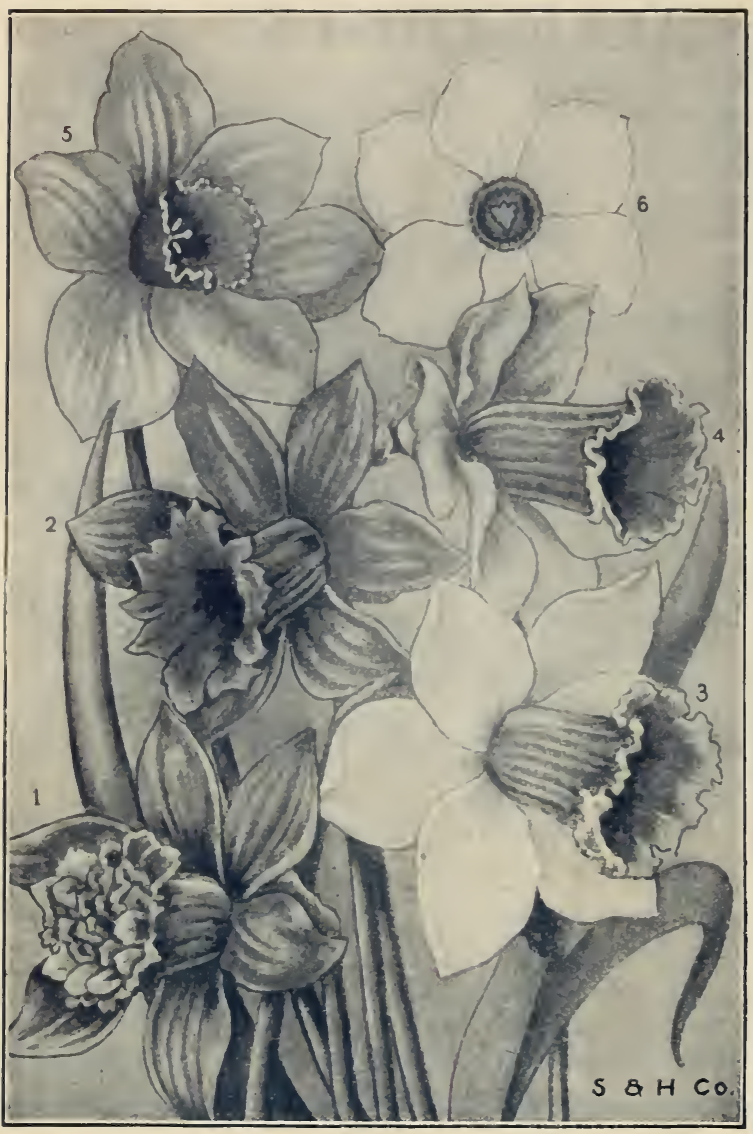

I. Double Von Sion.

2. Golden Spur.

5. Emperor.

6. Poeticus Ornatus.

\section{DOUBLE HARDY NARCISSUS}

Alba Plena Odorata - Snow-white, Each Doz, 100 Gardenia-like flowers; very sweet scented. "The double white Poet's Narcissus,

Incomparable "Butter and Eggs", Large double flowers, rich yellow, with orange center, fine for winter flowers .................... 4e 40

Orange Phoenix-Orange and lemon.. 4e 40e 200 Silver Phoenix-Creamy white and sulphur

Von Sion-The famous old Dutch Daffodil; a lovely shade of golden yellow; flowers large and of fine form (No. 1). 4e 3āe 175 If ordered by express at dozen rates, deduct $10 \mathrm{c}$ per dozen; 100 rate by express only.

\section{ChineSE NARCISSUS or SACRED LILY}

A variety of Polyanthus Nareissus, the flowers of which are beautiful waxy white, very fragrant, and appear in profusion in four to six weeks from time of potting. They do well if potted in soil, but make best ornaments when placed in shallow dishes of water, with enough gravel and fancy pebbles to keep from tipping over when in bloom. P'nt an inch or two of sand or fine gravel in the botton, on which place the bulb; place enough pebbles around the bulb to keep it in an upright position, then fill with water so that about one inch of bottom of bulb is covered. Set in a dark room for a few days until the roots start freely, then bring to the light and keep in any ordinary living room. A dozen bulbs liandled in this way, started at intervals, will give a succession of bloom throughout the winter.

$12 \mathrm{c}$ each; $\$ 1.25$ per dozen. If ordered by express, deduct $25 \mathrm{c}$ per dozen. Original baskets containing 3 ? bulbs, $\$ 2.00$, by express.

\section{SPECIAL COLLECTIONS OF BULBS}

\section{WINDOW COLLECTION}

We have taken pains to make up a collec. tion that would be within the reach of all and yet give variety and quantity enough to make a good show.

Price, Full Collection, by express, \$2.00; by mail, postage paid, $\$ 2.50$.

8 Hyacinths, 8 varieties, named.

6 Roman Hyacinths, assorted colors.

30 Tulips, early flowering, mixed colors.

10 Narcissus, named.

24 Crocus, 3 colors.

10 Freesias.

2 Calla Ethiopica.

2 Lily Harrisii (Easter Lily).

12 Snowdrops.

4 Scilla Siberica.

4 Tritelia Uniflora.

4 Glory of the Snow.

4 Allium Neapolitanum.

4 Oxalis.

10 Sparaxis, mixed.

10 Ixias, mixed.

One-half the above collection by express, $\$ 1.10$; by mail, postage paid, $\$ 1.30$.

\section{GARDEN COLLECTION}

A bargain collection of bulbs suitable for the hardy border, covering the best of the IIolland bulbs that may be used for outdoor planting, at prices which should cause a collection to follow this catalog into every home.

310 Beautiful Spring Flowering Bulbs, by express, for $\$ 3.00$; by mail, postage paid, $\$ 3.50$.

20 Hyacinths, single and double, assorted colors.

100 Tulips, single and double, mixed colors.

10 Parrot Tulips, mixed colors.

20 Nareissus, single and double.

100 Crocus.

10 Snowdrops.

10 .Jonquils.

10 Glory of Snow.

10 Scilla Siberica.

10 Tritelia Uniflora.

4 Grape Hyacinths.

4 Iris

2 Hardy Lilies.

One-half of the above collection by express, $\$ 1.50$; by mail, postage paid, $\$ 1.75$. 


\section{MISGELLANEOUS BULBS}

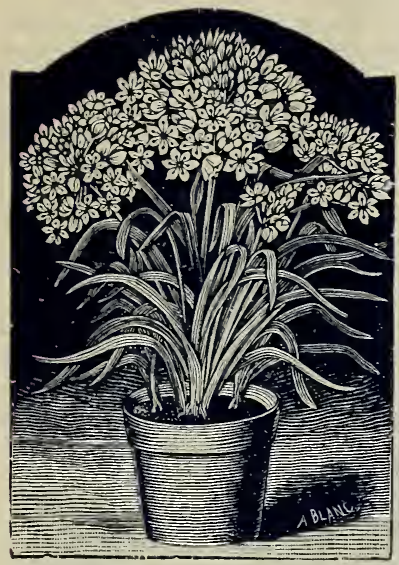

ANEMONES

Beautiful spring Poppy-like flowers of brilliant colors. They do well in light soil, well drained. Plant one inch deep, six inches apart, and cover with leaves during the winter, as they are not quite hardy in our northern climate. Four roots to a 5-inch pot, kept cool and secluded until growth appears, will produce handsome decorative specimens for winter use.

Single Scarlet

Each. Doz.

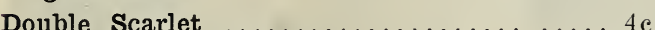

Single-All colors mixed ............ 3 e

Double-All colors mixed ............ 3e

$30 \mathrm{c}$

$20 \mathrm{c}$

$20 \mathrm{c}$

\section{GALLA LILIES}

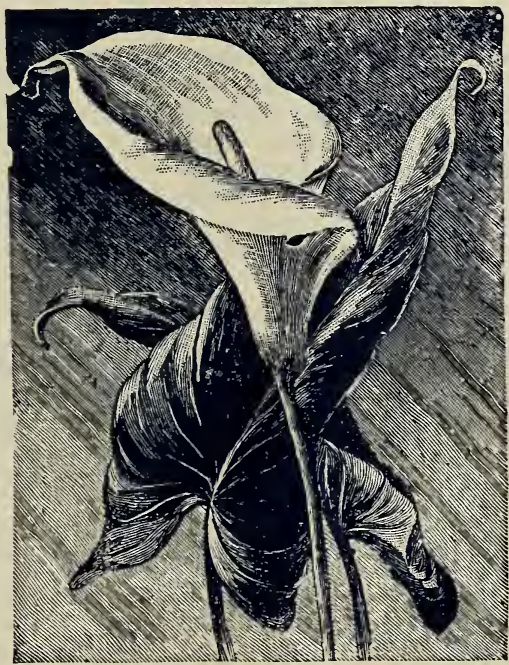

White Calla (Richardia Ethiopica)-The White Calla, or Lily of the Nile, is a well-known plant of easy culture, and in winter is one of our best window plants. To aid profuse blooming, keep them dormant from the middle of June to last of August, repot in good rich soil, using a 4 to 6 -inch pot, give water, light and heat in abundance, and the result will be most satisfactory. Strong flowering bulbs, $15 \mathrm{c} ; \$ 1.50$ per doz., by express. Extra large, 20c; $\$ 2.00$ per doz., by express.
Spotted Calla (Richardia Alba Maculata)-Always ornamental; its dark green leaves, beautifully spotted with white, making a fine shown even when not in bloom. Equally good as a pot plant or for summer garden. $10 \mathrm{c} ; \$ 1.00$ per doz.

\section{CHIONODOXIA}

\section{(Glory of the Snow.)}

Lovely and hardy spring flowering bulbous plants, and as edgings to beds or in clumps or masses; flowering very early in spring, with Snowdrops, and lasting a long time in perfection. They thrive in good garden soil, and are equally admirable for winter flowering in the house.

Gigantea-Extra large flowers, beautiful lilac blue with white center. 3 for $10 \mathrm{c} ; 20 \mathrm{c}$ per dozen.

Iucillae-Spikes of azure blue flowers, with pure white centers. 3 for $10 \mathrm{c}$; $20 \mathrm{c}$ per doz.

\section{CROCUS}

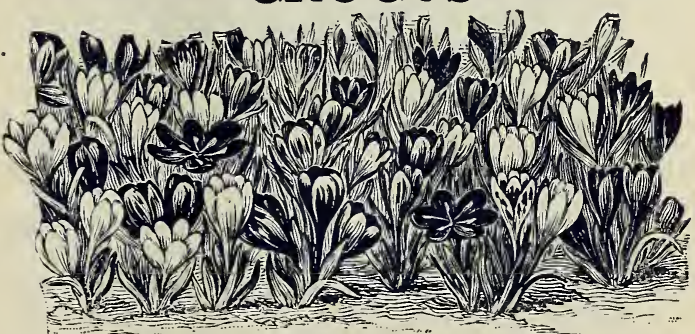

These dainty little flowers are among the first to break through the bands of winter and are cheerful heralds of approaching spring. No better show of delicate bloom at this transition point between bleak barrenness and reviving vegetation can be obtained at so trifling an expense as an assortment of Crocus planted the preceding autumn in the lawn or in rows along the edges of walks. Beds arranged in alternating rows of golden-yellow, striped purple and pure white, make a splendid show.

\section{CHOICE NAMED LARGE FLOWERED GROGUS} Baron Bruno-Deep blue $\ldots \ldots \ldots \ldots \ldots \ldots .12 \mathrm{c} \quad 75 \mathrm{c}$ Cloth of Gold-Yellow ............... $75 \mathrm{e}$ Grootvorst_White ................. $75 \mathrm{c}$ Giant Yellow-Extra large golden yellow...15e 85e Mont Blanc-Large white ............. $75 \mathrm{e}$ Prince Albert-Large brilliant purple.....12e 75e Sir Walter Scott-Striped blue and white...12e 75e Any of above in 1000 lots, $\$ 6.00$ per 1000 .

\section{MIXED GROGUS}

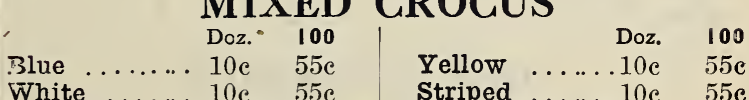
All colors $\$ 3.50$ per 1000 by express.

\section{IXIAS}

A beautiful little winter flowering bulb with slender, graceful spikes of bloom. Colors are varied and attractive; the center always differing in color from the rest of the flower. Half a dozen bulbs may be planted in a 5 -inch pot. For open ground culture give them winter protection with leaves or straw. Finest mixed, 2 for $5 \mathrm{c} ;$ per doz., $15 \mathrm{c}$. 


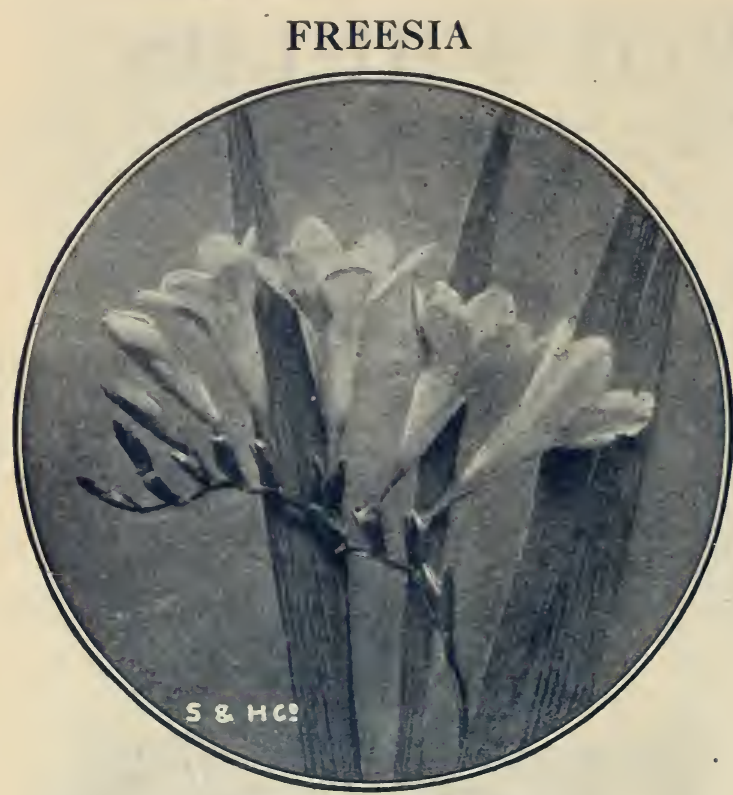

The beauty and freedom of their flowers, their exquisite perfume, lasting qualities, and the ease with which they may be forced, make this species of great importance among winter blooming bulbs.

A succession may be maintained from Christmas until June. Plant 6 or 8 bulbs in a 5 -inch pot and (contrary to usage with most bulbs) set directly into the light.

Refracta Alba-Blooms in long racemes of five to eight large, tubular florets, pure white. Cut flowers will expand and keep in water for two weeks, scenting the entire house. 2e each; 20c per dozen; \$1.25 per 100 . Mammoth Blubs, 3c each; 25c per dozen; $\$ 1.75$ per 100 .

\section{GLADIOLUS}

The following two varieties are very early flowering and liave come into general use for foreing. The flowers are quite large with long stems, and are borne freely. A six-inch pot will nicely care for six bulbs. If planted outdoors, they will need protection in winter.

Blushing Bride (Delicatissima)-Ivory white, with carmine bloteh on lower petals. 25e per dozen; $\$ 1.50$ per 100.

The Bride-Pure white. 20c per dozen; \$1.25 per 100.

\section{IRIS ANGLICA}

\section{(English Iris.)}

Large, handsome flowers, with rich purple, blue and lilac colors predominating. Grows 18 to 20 inches high; perfectly hardy.

Mixed Varieties, 3 for 10c; per doz., 25c; \$1.50 per 100.

\section{IRIS HISPANICA}

(Spanish Iris.)

For garden planting, bulbs should be set out early in the fall, 2 to 3 inches deep and 6 inches apart, preferably in beds of generous size. For winter use, pot and handle similarly to Hyacinths, bringing the pots up for blooming about March. The flowers of this lovely species are not large, but in shape and delicate tinting rival the choicest Orchids. They come in definite shades of violet, yellow, blue and white.

Mixed Varieties, 2 for 5c; 15 c per doz.; $\$ 1.00$ per 100 .

\section{IRIS KAEMPFERI}

(Japan Iris.)

Finest of all the Iris family. The flowers are of immense size, occasionally 10 and 12 inches in diameter, and of the most beautiful and delicate shades. They are perfectly hardy, and flower in great profusion during June and July. A well-established plant gives a dozen or more flower stalks two to three feet high, each stalk producing two to four enormous blooms.

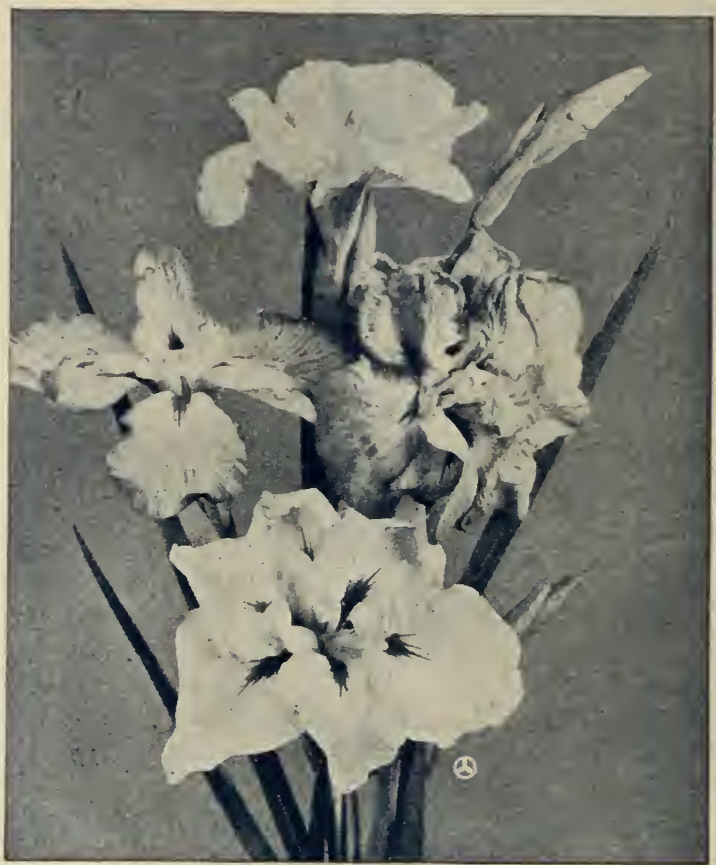

The following varieties are numbered and arranged according to their relative blooming season; the entire collection providing a 1ong succession.

Gekka-no-nami (Waves under Moonlight) (1)-Earliest to bloom, and the choicest white; very free. Glistening white with creamy white stigmas.

Momiji-no-taki (Maple Waterfall) (2)-A choice, double variegated variety; bright crimson purple, beautifully feathered in white. Petaloid-stigmas white, purple crested.

Purple and Gold (3)-Enormous double flowers often ten inches across, early and free blooming; one of the very best varieties. Color, rich violet-purple with white petaloids tipped violet. The conspicuous golden throat extending outward in sharp bluisl white rays, strongly suggests a bearded wheat head.

Gold Bound (4) - A fine double pure white, with gold banded center.

Hana-no-Nishiki (Flower Embroidery) (5)-Six to eight petals in conical arrangement, with well developed petaloids, make this sort the most fully double in the collection. Color a distinct claret-pink, with fine white veins. $25 \mathrm{c}$.

Eclipse (6)-Velvety claret-red shaded violet, with prominent throat markings in pure gold. Flowers extremely large; with six wide petals, and petaloidstigmas so fully developed as to make an extra row at the center. Special. 25c.

Mahogany (7)-Large double flowers, the latest to bloom. Purpled mahogany-red; the erect petaloids prettily crested.

Unless noted, 20c each; $\$ 2.00$ per dozen; set of 7 for $\$ 1.25$. By express, $\$ 1.50$ per dozen; $\$ 10.00$ per 100 . 


\section{IRIS GERMANIGA}

(German Iris.)

Familiar and well beloved flowers of spring. The purity of their beauty, and their haunting fragrance, are decidedly refreshing. They are perfectly hardy, thrive anywhere, grow and bloom luxuriantly, particularly if plentifully supplied with water or if planted in moist situations, as on banks of ponds, etc. Plants well established produce from 50 to 100 spikes of bloom.

Canary Bird-Falls creamy white, uppers light canary yellow; medium sized flower.

Celeste-Falls bright blue, uppers delicate grayish blue; all having a lavender effect. $15 \mathrm{c} ; \$ 1.50$ per doz.

Conspicua-Falls deep maroon, uppers buff and yellow; large flowered.

Cubero-Rich orange yellow, lower petals streaked maroon.

Florentina Alba-Sweet scented, free flowering white.

Fulda-Satiny white; lower petals lilac, feathered yellow.

Her Majesty-Falls crimson over white, giving flower a slightly striped effect; uppers bright lavender rose. A fine large flower.

Mad. Chereau-Very delicate and distinct; white, edged blue. $15 \mathrm{c} ; \$ 1.50$ per doz.

Mrs. H. Darwin-Falls satiny white, veined crimson; uppers white with slight crimson penciling at base. $15 \mathrm{c} ; \$ 1.50$ per doz.

Parisensis-Large, showy deep purple, delicately penciled white.

Unless noted, 10c each; $\$ 1.00$ per dozen; $\$ 6.50$ per 100

\section{MISCELLANEOUS IRIS}

Iris Pallida Dalmatica-Of the Germanica type, growing 3 to 4 feet high, strong, vigorous and free blooming. Flowers large and fragrant, lavender shaded blue in the falls. Delicately beautiful and exceptionally valuable for massing. $25 \mathrm{c} ; \$ 2.50$ per dozen. .

Iris Sibirica-A useful cutting sort, bearing quantities of purplish blue flowers on slender scapes 3 feet high. $15 \mathrm{c} ; \$ 1.25$ per dozen.

\section{IXIAS}

A beautiful little winter flowering bulb with slender, graceful spikes of bloom. Colors are varied and attractive; the center always differing in color from the rest of the flower. Half a dozen bulbs may be planted in a 5-inch pot. For open ground culture give them winter protection with leaves or straw. Finest mixed, 2 for $5 c$; per doz., 15c.

\section{LILIES}

No garden collection can be complete without the Lily prominently established. With no extraordinary care, Lilies will thrive co-equal with the hardiest garden plants, and by arranging a judicious assortment of varieties a continuous succession of flowers may be had from May until November.

NOTICE.-Owing to the difference in time of maturing among the various Liliums and the delays of separate importations, we divide the sorts in this list according to the general time when we can fill orders. Please observe these dates carefully in ordering, to avoid disappointment and misunderstanding.

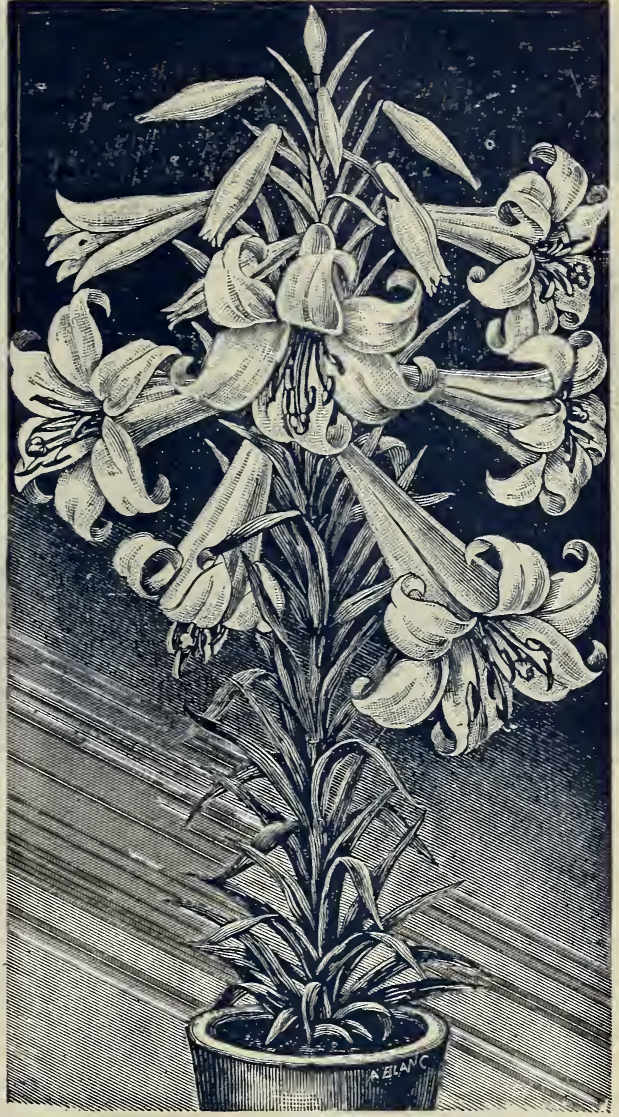

EASTER LILY.

Early Delvery in August and September.

Candidum-The old-fashioned, pure white garden Lily. Also known as Annunciation and Madonna Lily. One of the hardiest. A grand variety for winter flowering in pots. Very fragrant. 10c each; $\$ 1.00$ per doz.

Formosum-A fine form of the Longiflorum type, pure white. $15 \mathrm{c}$ each; $\$ 1.50$ per doz.

Harrisii (The Bermuda Easter Lily)-The grandest of all Lilies for winter flowering. The flowers are large trumpet-shaped, pure waxy white, gracefully formed and delightfully fragrant. The ease with which it can be forced into flower in winter has made it wonderfully popular as a winter flower. Tens of thousands of it are grown every year for church decorations at Easter. Each bulb will give from 5 to 20 flowers, according to size. First-class bulbs, 10c each; $\$ 1.00$ per doz. Extra bulbs, 20c each; $\$ 2.00$ per doz. Mammoth bulbs, 30c each; $\$ 3.25$ per doz.

\section{Delivery in October}

Elegans Robusta-Bright orange flowers of immense size, blooms in July. $10 \mathrm{c}$ each; $\$ 1.00$ per doz.

Tigrinum Splendens (Tiger Lily) - Single flowers of orange, spotted black. 2 to 5 feet. $10 \mathrm{c}$ each; $\$ 1.00$ per doz.

Tigrinum, fl. pl. (Double Tiger Lily)-Bright orange scarlet with dark spots, a strong growing, showy variety, and entirely hardy. Succeeds well everywhere. $10 \mathrm{c} ; \$ 1.00$ per doz.

Philadelphicum-A hardy native Lily, bright red spotted purple. $10 \mathrm{c}$ each; $\$ 1.00$ per doz. 


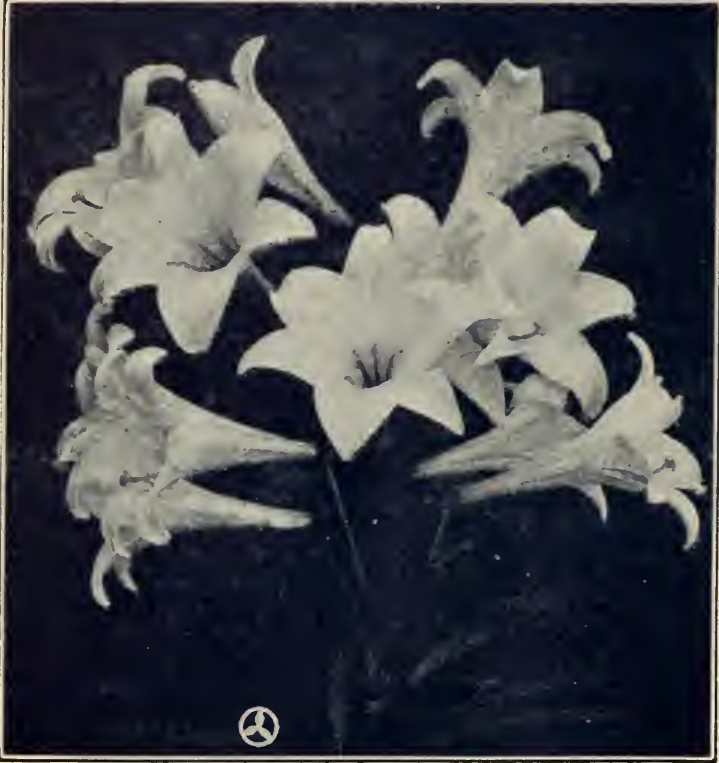

LILIUM LONGIFLORUM

Longiflorum-A well-known beautiful variety, with snow-white trumpet-shaped flowers that are rery fragrant. It is quite hardy and blooms freely in the open ground in June and July. Is also used largely for forcing for the Easter holidays; the flow. ers have more substance and last longer than the Bermuda Lily. First-class, 10e each; $\$ 1.00$ per doz. Extra size, 15e each; $\$ 1.50$ per doz.

\section{Late Delicery in Noicmber and December.}

It would be an advantage to lay out the proposed Lily-beds or borders to contain the following varieties, early in the autumn; covering ground with a litter of leaves or other substance to about 6 inches. This will insure a proper soil condition to receive the bulbs when they arrive, even in December.

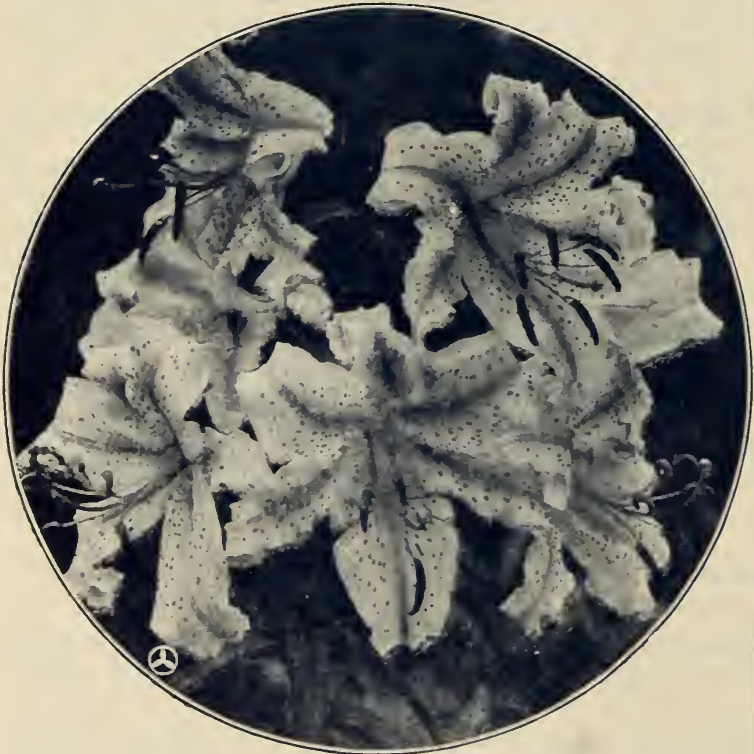

GOLD BANDED LILY-AURATUM.

Auratum (Fold-landed .Japan Lily) - Considered lw many the finest of all hardy Lilies. Flowers very large, made up of broad white petals, thickly stuilded crimson maroon and a bright golden hand through the renter of each petal. As the bulbs acquire age anl strength, the flowers attain their maximum size and number. Stalks from good-sized bulbs frequently have from 12 to 15 flowers. $15 \mathrm{e}$ each; $\$ 1.50$ per doz; extra large bulbs, 2.je each; $\$ 2.50$ per $10 \%$

Krameri-Large flowers from June in August; a beau-

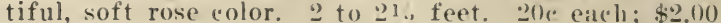
per $10 \%$.

Rubellum-Medium sized flowers of muspotted pink; very pretty. 20c; $\$ 2.00$ per $10 \%$

Speciosum Album-Very fragrant large flowers, pure white with a green band running through the center of each petal. One of the best. 15c each; $\$ 1.50$ per doz.

Speciosum Melpomene-Large deep crimson, heavily spotted. 20c each; $\$ 2.00$ per doz.

Speciosum Rubrum-White, beautifully spotterl red; flowers in August. $15 \mathrm{e}$ each; $\$ 1.50$ jer doz.

\section{LILY OF THE VALLEY}

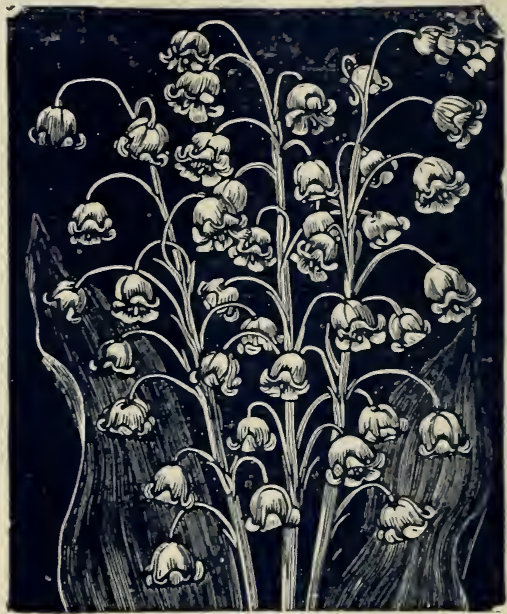

Forced in immense quantities for cut-flower work by florists, as they are useful in so many different combinations, but their main hold upon the affections of plant lovers is their hardiness and bumility. The Lily of the Valley will thrive in any kind of soil and throw up its beautiful, modest, fragrart white bells in the out-of-the-wuy nooks, the shady spots, the neglected corners, where bolder and more ambitious flowers would scorn to bloom. Will also adapt itself to pot culture in winter, its delicate, permeating fragrance making it especially desirable. Je each; 35. per do\%.; $\$ 2.25$ per 100 .

\section{OXALIS}

Should be potted as early as possible in goor light sandy loam and put away in dark for two or three weeks to allow good root growth, after which place in sumy window. The bulls are so small that for good effect they should he potted 4 to is in 5 -inch pot. Buttercup-Always a prime favorite; grows and flowers well everywhere. Flowers are of purest possible shade of buttereup yellow. 4e each; 3ise per doz.

Grand Duchesse-Beautiful California Oxalis, with large double flowers well displaved above the foliage, growth dwarf and stmily. Your choice of four varieties:

\footnotetext{
- White-4c each; 3is jer 11 $1 \%$

Pink-oc each; .joe per doz.

Lavender - 3e each; 2.) per lo\%.

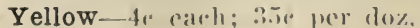




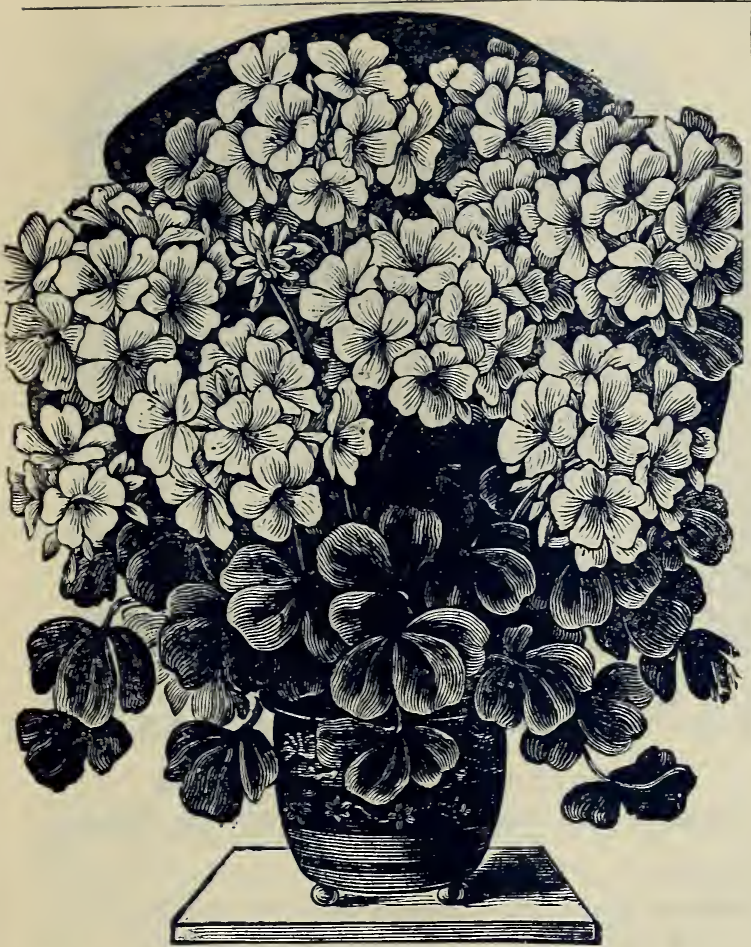

Oxalis Bowei-Bright rose. 3 for $10 \mathrm{c}$; per doz., $25 \mathrm{c}$.

\section{RANUNGULUS}

Among the smaller flowering spring plants these are without a peer in the richness of coloring and profusion of bloom. The flowers are beautifully shaped and range through all the most brilliant shades of white, crimson, yellow, purple and black, some being variegated. They should be planted from October to December in drills, in a moist soil. To protect from severe frosts, cover with leaves.

Double Persian Mixed-Rose-shaped flowers, very double. 3 for 10c; per doz., 20c.

Double French Mixed-Very large, gorgeously colored flowers. 3 for 10c; per doz., 20c.

\section{SCILLA SIBIRICA}

Early spring flowering bulbs, of dwarf habit, from six to eight inches in height, with drooping, bellshaped blossoms of bright blue. They are quite hardy, growing in any good, light soil. Very suitable for growing in pots. 3 for 10c; per doz., 20c; $\$ 1.25$ per j00.

\section{SNOWDROPS}

The earliest of spring flowering bulbs, universally admired for their snow-white, drooping blossoms. 'They succeed well in any soil, and should be planterl where they are to remain, as the bloom best when not disturbed.

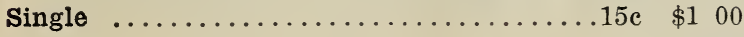

Double .....................25c 175

Elwesii (The Giant Snowdrop)-Flowers pure white,

frequently spotted gree.1 on inside. $15 \mathrm{c}$ doz.; $\$ 1.00$ per 100 .

\section{SPARAXIS}

A companion to the Ixia. The flowers are more trumpet-shaped and larger, and are of varied and striking colors, being blotched, striped and spotted in the most pleasing manner. 2 for $5 \mathrm{c}$; doz., 20c.

\section{SPIREA or ASTILBE}

(By Freight or Express Only.)

The Spireas furnish the largest flowers of any of the bulbous plants, rising well above the foliage in numerous pyramidal, feathery plumes. Most varieties are adapted to the hardy border, preferring moist locations, and cover themselves with fleecy bloom in June; they are mainly used, however, for indoor foreing. Any light soil will do, and any reasonable temperature, but at blooming time (10 to 14 weeks after potting) should be kept under 60 degrees. Liberal watering must not be neglected.

Japonica-The original; very hardy and productive. A splendid cut-flower source. Creamy white.

Florabunda-Pure white; very profuse bloom.

Blondine-An improved pure white, of dwarf, compact habit. 20c each; $\$ 1.75$ per doz.

Gladstone-Growth strong and bushy; plants often supporting 2.5 to 40 magnificent flower trusses of purest snow-white. 25c each; $\$ 2.00$ per doz.

Queen Alexandra (New)-Graceful pyramids of warm, glowing pink. 25c. each; $\$ 2.00$ per doz.

Superba-An improved form of the Florabunda type, having larger and more perfectly formed blooms. $20 \mathrm{c}$ each; $\$ 1.75$ per doz.

Unless noted, 15c each; $\$ 1.50$ per doz.

\section{TRITELIA UNIFLORA}

\section{(Spring Star-Flower.)}

A pretty little bulbous plant suitable either for outdoor culture or growing in pots. Flowers star-shaped, one inch in diameter; pure white, lined with delicate blue. 2 for $5 \mathrm{c}$; doz. $20 \mathrm{c}$.

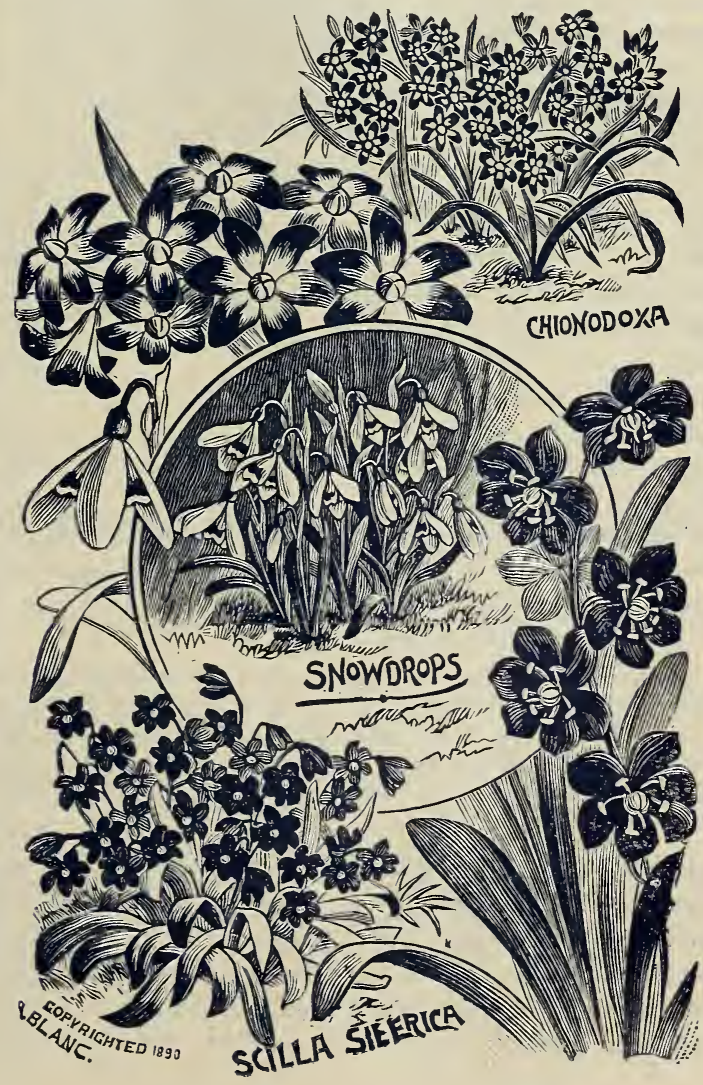




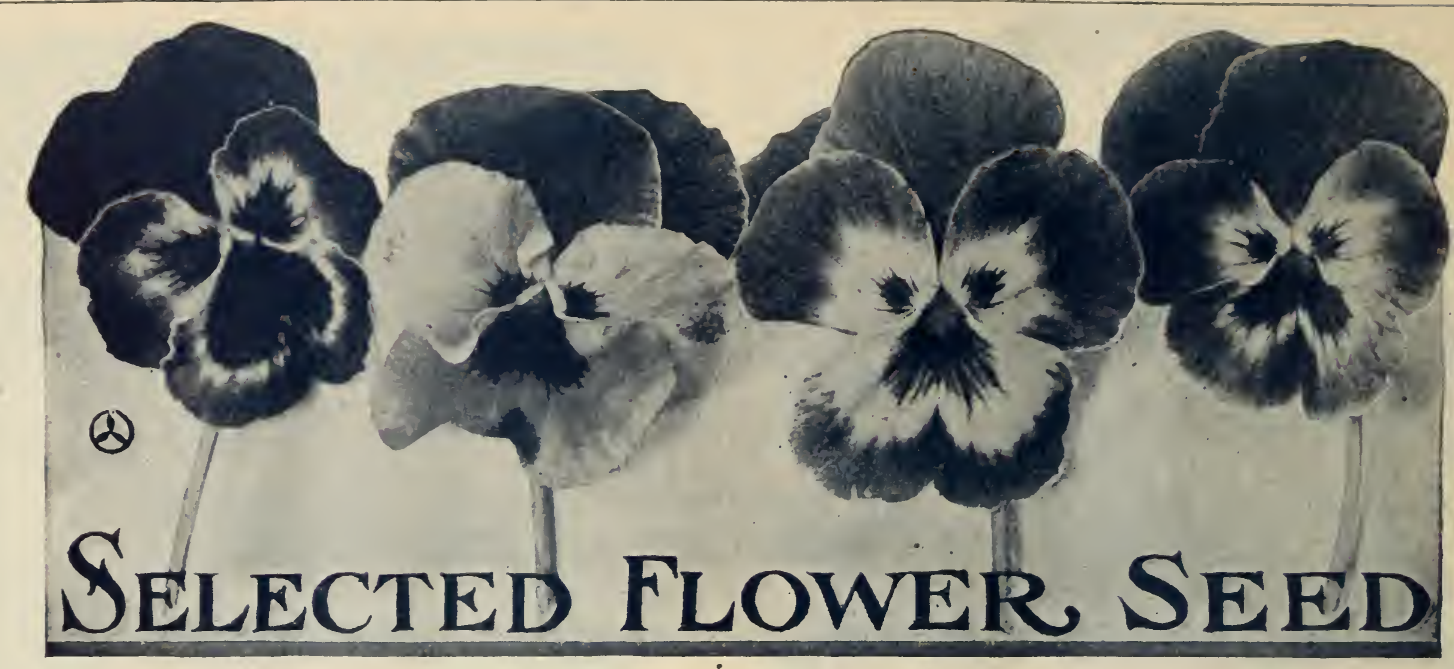

\section{FOR FALL AND WINTER SOWING}

\section{*PANSIES, Superb Giants}

Exceedingly rich color and form, as well as the largest sized flowers.

Masterpiece-Giant Curled

Andromeda-Lavender and pink

Adonis-Light blue, white center

Pres. Carnot-Violet, margined white

Pres. McKinley

Prince Henry-A fine large, deep clear blue; the best bluc variety yet introduced............10

Aureola_Deep red, upper petals light yellow with carmine zone

Orchideaeflora-New, very interesting type; flowers resemble an Orchid in their wonderful and quaint shape as well as in the charming shadings. Mixed colors

Mad. Perrett-Frilled edges

Ruby

Bridesmaid-Rosy white with dark blotches....

Lord Beaconsfield-Purple and lavender.

Black

Peacock-red, white and blue.

Yellow

White

Striped

One pkt. each of the above 15 Giant Pansies for $\$ 1.00$ One pkt. each of 7 distinct Giants, our choice, $50 \mathrm{c}$. Superb Giant-Mixed, of all the above, pkt., 10c; 3 pkt., 25c; 1/s oz., \$1.00.

Many of our hardy Annuals and Perennials may be sown in the fall. The Perennials should be planted early enough to make good strong plants before severe weather sets in, while the Annuals will do better if planted late enough to have the seed remain in the ground through the winter, coming up early in spring. Varieties marked with a * should be planted by middle of September. The others any time before winter. For full description of varieties see Catalogue No. 2 for 1911.

Alyssum-Sweet, oz., 25c; 1/4 oz., 10c Alyssum-Little Gem, 1/1 oz., 15c.

*Anemone Coronaria-Double mixed

*Antirrhinum-Pink-scarlet, each

*Antirrhinum-TVhite-yellow-mixed, each

*Aquilegia (Columbine)-Mixed double Double white
*PANSIES, Excelsior Strain (Smaller than Superb Giants, but fine for bedding.)

Cardinal-Brilliant red .............. Pkt.

Emperor Frederick-Flowers dark red shading into crimson; margined yellow ............... 5e

Emperor William-Large fine flower, ultra-marine blue, with purple violet eye............ 5e

Fairy Queen-The color is a pure delicate sky blue bordered with clear white .............. $5 c$

Havana Brown-Light brown ............ $5 \mathrm{c}$

King of the Blacks-Almost coal black....... $5 \mathrm{c}$ Lord Beaconsfield-Deep purple violet, shading to lavender and white .................... 5 c

Mahogany Colored-Very dark, glossy brown... 5c Quadri-Color-Reddish steel blue, with red and white edge ......................... 5 c Silver Edged-Maroon and purple, edged white.. 5e Snow Queen-A pure white flower of good form and size; some have purple centers......... 5c Striped and Mottled-An interesting class with flowers of various shades and stripes......... $5 \mathrm{c}$ Yellow-Pure golden yellow, some of the flowers have dark centers .................... One packet each of the above 14 Excelsior Pansies for $45 c$.

One packet each of seven distinct Excelsior Pansies, our choice, for $25 \mathrm{c}$.

Excelsior Mixed - This mixture is made up of the above named colors and other desirable mixtures. 6 pkts., 25c; 1/1 oz., \$1.00 ............. $5 \mathrm{c}$

\section{Pkt.} $5 c$ $5 c$ $5 \mathrm{c}$ $5 c$ je
*Aquilegia Chrysantha, canary yellow.......... Pkt. Cerulea, blue and white ........ Bachelor Button-Double-single, each ........ 5 c *ampanula (Canterbury Bell)-Double mixed .. 5e (Canterbury Bell)-Single mixed... 5c Carpatica-Mixed ............ 5e

Candytuft-Mixed ................ 5 c Little Prince, dwarf white ...... 5c 
Candytuft-Empress, white Perennial, Hardy evergreen, white.. *Coreopsis-Lanceolata Grandiflora .......... *Daisy-Double red

Double white

Double, mixed, choice

* 6

Shasta-Large, single, white flowers....

*Digitalis-Foxglove, mixed ............ 5 c

*Gaillardia-Grandiflora $\ldots \ldots \ldots \ldots \ldots \ldots \ldots .5 \mathrm{c}$

*Hibiscus-Crimson eye ............. 5c

*Hollyhock-New mammoth fringed, mixed..... 10c “ Double maroon-pink-red, each .. 10

" Double white-yellow, each ...... 10c

"، Double mixed ............... 5

*Larkspur Perennials-Formosum ......... 5c " " $"$ Coelestinum ......... 10 c " " Choice Hybrids, mixed ... 5c

*Lathyrus Latifolius-Mixed ............ 5c * "6 "6 Pink-red-white, each .. 5c Lobelia Cardinalis-Crimson scarlet ....... 10c Lobelia Syphilitica-Large light blue ...... 10 c *Lychnis Chalcedonica .............. $5 \mathrm{c}$ * Myosotis (Forget-me-not)-Palustris ....... 5c *Myosotis-Dissitiflora-Victoria, each ...... $5 \mathrm{c}$ *Phlox-Perennial choice mixed.......... 10 c *Pink (Double Japan)-Mixed .......... 5c " (Fireball)-Scarlet ............. $5 \mathrm{c}$ " (White Snow Queen) ............ 5c " (Chinensis)-Mixed .............. 5c " (Choice Mixture)-Annual varieties, $1 / 4$ oz.15c 5c “ (Hardy Perennial)-Plumarius fl. pl. mixed 10c “ (Hardy Perennial)-Plumarius single,mixed 10c Pyrethrum Roseum Hybridum-Single Pyrethrum Roseum Hybridum-Double ....... 25c Sweet William-Mixed Double-Single, each .... 5c Wild Cucumber-Oz., $15 \mathrm{c} \ldots \ldots \ldots \ldots \ldots \ldots \ldots \ldots$ c

\section{POPPY}

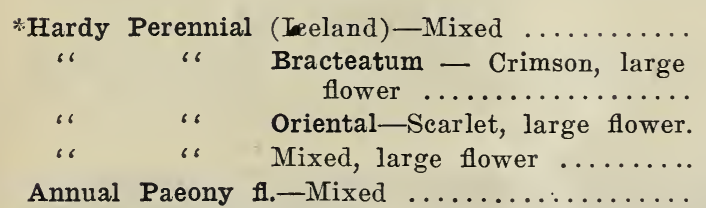
Carnation fl.-Mixed ............ $5 \mathrm{c}$

Double Mixed-Single Mixed, each.... 5c

\section{FOR THE HOUSE OR CONSERVATORY}

Abutilon (Flowering Maple)-Mixed.........10 c Browallia Speciosa Major.............. 10 c Canary Bird Flower-A pretty climber....... 5c Carnation-Extra choice, double mixed .......20

" Double mixed ...............10c

" Marguerite, mixed ......... 5c

“ Marguerite, pure white-pink, each.. 10c

" Marguerite, erimson-striped, each .. 10c Calceolaria-Finest mixed ............. $25 \mathrm{c}$ Cineraria-Finest mixed grandiflora $\ldots \ldots \ldots \ldots 35 \mathrm{c}$ Cineraria-Choice mixed .............. 15c Cyclamen Persicum

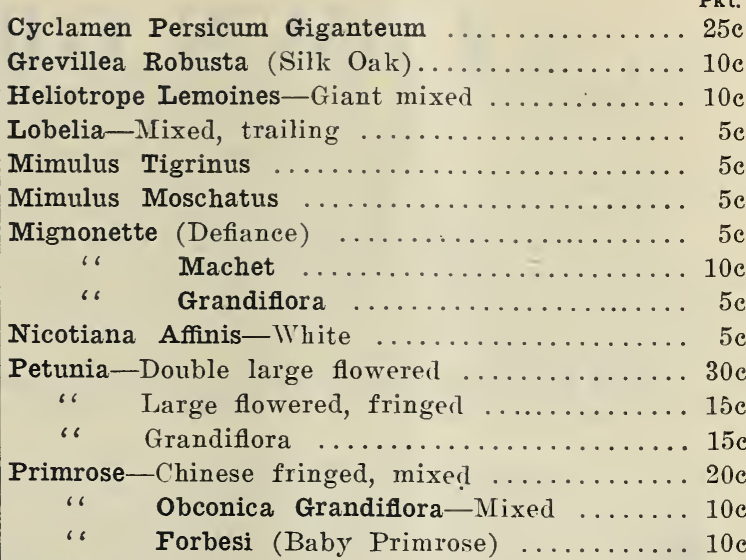

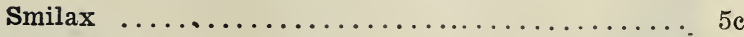

Thunbergia-Fine mixed $\ldots \ldots \ldots \ldots \ldots \ldots \ldots$

\section{SWEET PEAS}

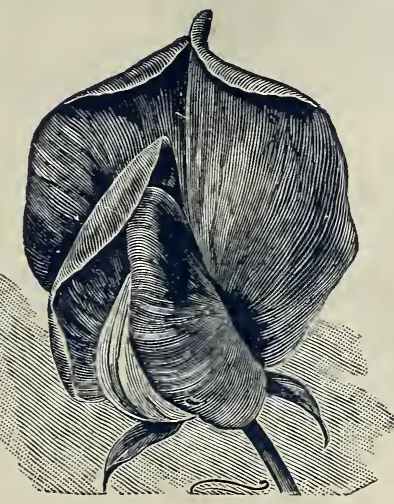

They may be planted about October 1st, and slightly protected during winter, although this is not absolutely necessary. IVill bloom early in spring.

New "Spencer"

Sweet Peas

Apple Blossom-Oz. $20 \mathrm{c}$, pkt. $10 \mathrm{c}$.

White Spencer-Oz. $15 \mathrm{c}$, pkt. $10 \mathrm{c}$. Aurora Spencer-Oz. $25 \mathrm{c}$, pkt. $10 \mathrm{c}$.

Asta Ohn Sper_cel-Uz. 25c, pkt. 10c.

Geo. Herbert Spencer-Oz. 15c, pkt. 10c.

King Edward VII Spencer-Oz. 25c, pkt. $10 \mathrm{c}$.

Paradise Spencer-Oz. 15c, pkt. 10c.

Primrose Spencer-Oz. 15c, pkt. 10c.

A Mixture of the Above-All varieties. Pkt. 10c, oz. $15 \mathrm{c}, 1 / 4$ lb. $40 \mathrm{c}, \mathrm{lb}$. $\$ 1.25$.

\section{General List of Eckford's Strain of Mammoth Flowered Sweet Peas}

Per Packet, $5 \mathrm{c}$.

Per $1 / 4$ lb. $25 \mathrm{c}$.

America.

Coccinea.

Dorothy Eckford.

Earliest of All.

Hon. Mrs. E. Kenyon.

Janet Scott.

Jessie Cuthbertson.

John Ingman.

Katherine Tracy.

King Edward VII.

Lord Nelson.
Per Ounce, 10c.

Per 1b. 60c.

Mrs. Walter Wright.

Mrs. Geo. Higginson, Jr.

Othello.

Queen Alexandra.

Salopian.

Senator.

White Wonder.

Eckford's Mammoth fl. mixed.

Cupid Mixed. 


\section{LAWN GRASS SEED}

In fitting the grouml for a lawn, eare should be taken to have the work properly done throughout, as in that condition it will last for years; but if slighted in the beginning it will be a constant source of annovance and expense. If there is grading to be done, the top soil to the depth of eight or ten inches should first be removed to one side and used in finishing the gratle.

The soil should be thoroughly harrowed, then raked to reluce to as fine a condition as possible, as well as to level it, as nothing detracts so much from the appearance of a law as an nneven surface. As a fertili\%er we would recommend pure bone moal as being lasting in its effects, and free from weel seeds. Apply at the rate of 600 to 1,000 pounds to the acre. After the seed has been sown it should be raked lightly so as to eover it. Sow the sesel in the fall before antmun rains have ceassol, the earlier the better, if the soil is in good condition.

Prices quoted by the pound and 3 pounds are postage paid by us; if ordered by express, deduct $8 \mathrm{c}$ per pound. Larger quantities are by express or freight, purchaser paying charges.

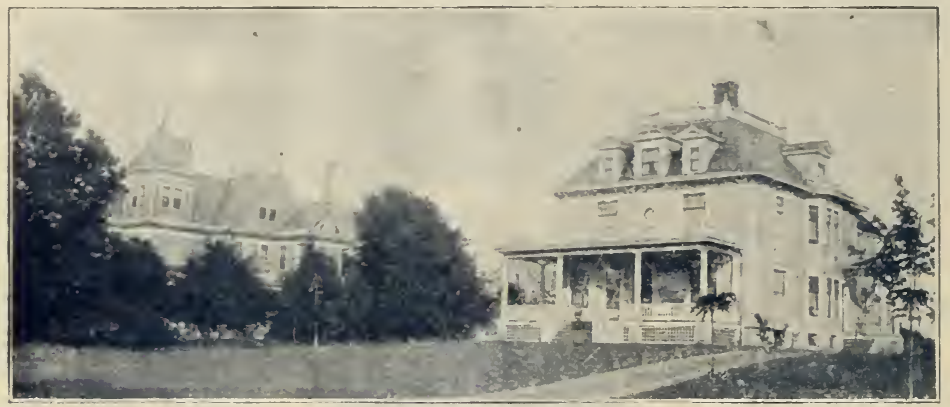

Velvet Sod Lawn Mixture

Velvet Sod Mixture-A mixture of fine dwarf, close growing grasses, that will produce a neat velvety lawn and permanent sod in a short time. Neiglit 20 pounds to the bushel. One pound will seed about 300 square feet; 80 pounds, or 4 busliels, are required for an acre. Lb., .j0c; 3 lbs., \$1.3.5; prostage paicl. By express, 5 llos. at $30 \mathrm{c}$; 20 lbs. at $25 \mathrm{c} \mathrm{lb.}$

Velvet Sod Mixture (for shaded places)-Lb., 5.5c; 3 lbs., \$1.50; .5 lbs., at 35c; 20 lbs. at 30e per lb.

Fancy or Double Extra Clean Blue Grass-Weighs 20 to 25 lls. to the linshel. I.1)., 4.5e; 3 lls., $\$ 1.20 ; 10$ liss. and over at 30 c.
Red Top Fancy-Re-cleaned seed. 32 lbs. per bushel. IAb., 35e; 3 lbs., $\$ 1.00 ; 10$ lhs. and over at $22 e$.

\section{VEGETABLE SEEDS FOR FALL SOWING}

If ordered by express in quantities of $1 \mathrm{lb}$. and upwards, $8 \mathrm{c}$ per lb. may be deducted.

CABBAGE

All Head Early-Plit., эr; 0z., 20e; 1/1 1h., (i0e; 11 ., $\$ 2.00$.

Charleston or Large Wakefien- $1 \%$., 5x; $0 \%, 20 c$; $1 / 1$ lb., 70c; 1b., \$2.25.

Danish Ball Head-Plkt., je; $0 \%, 830 ; 1 / 4$ 1b., $\$ 1.00$; lb., \$3.50.

Houser-Pkt., 5c; oz., 25e; 1/4 lb., 7.je; lb., \$2.50.

Selected Early Jersey Wakefield_P'lit.. г; o\%, 20e; 1/1 lb., 70c; lb., $\$ 2.2 .5$.

Selected Premium Flat Dutch--Plit., ie; $0 \%, 20 c$; 1/1 lb., 50c; lb., \$1.75.

Surehead-Pkt., 5c; oz., 20c; 1/4 11)., (ioc; lb., $\$ 2.00$.

Winningstadt-I'kt., 5('; 0\%, 15e; 1/4 11)., 4.je; 11., \$1.50.

\section{DANDELION}

Thick Leaved French-Plit., 5e; 0\%, 40\%

\section{ENDIVE}

Large Green Curled-Pkt., je; oz., 15x; 1/4 lb., 3.). White Curled-I'kt., כe; 0\%, 15(c; 1/1 11., 35e.

\section{KALE or BORECOLE}

l'kt., 5e; $07 ., 10 c ; 1 / 4$ lb., 30e.

\section{LETTUCE}

Big Boston-Pkt., je; n\%, 15e; 1/4 1b., 40e; 11)., \$1.25. Black Seeded Simpson-Pkt., 5̄e; oz., 15e; 1/1 lb., 3.̄e; lb., \$1.25.

Denver Market-P'kt., Бе; n\%, 15e; 1/1 lb., 35e: 1l., $\$ 1.00$

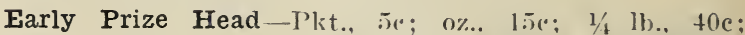
lb., \$1.25.

Grand Rapids-I'kt., 5e: $0 \%, 15(\cdot ; 1 / 4$ Ib., 4.)(*; 1!., \$1.25. Improved Hanson-Plkt., is.; o\%., 15e; 1/4 1b., 40e: lb., \$1.25.

Salamander-Plit., 5e; oz., 1.je; 1// lb., 40e; lb., \$1.25.

\section{MUSHROOM}

One pound will plant 8 to 10 square feet of bed. It is put $u p$ in bricks weighing about $1 \frac{1}{4}$ lbs. each. A leaflet giving full cultural directions will be sent with each orler.

Lambert's Pure Culture Spawn-This method insures the reproluction of a certain type, free from all inferior sorts, that will largely increase the yield and produce the very best Mushrooms. 35e per brick; 2 for 6.); by express, 5 briaks for $\$ 1.00$; 10 bricks or over at $18 \mathrm{c}$ per brick.

\section{ONIONS}

Yellow Globe Danvers-Extra selected. A choice home grown strain. Pkt., 5e; 0z., 25e; 1/4 lb., 65e; lb., $\$ 1.75$; by express, $5 \mathrm{lb}$. or more at $\$ 1.25$ per $1 \mathrm{l}$. Southport Red Gloke-Pkt., je; oz., 25e; 1/1 lb., 65e; lb., $\$ 2.00$.

Large Red Wethersfield-Pkt., 5c; oz., 20c; 1/4 lb., 65c; lb., $\$ 2.25$; by express, 5 lb. or more at $\$ 2.00$ per lb. Southport White Globe-Pkt., 5e; 0\%., 35e; 1/4 lh., \$1.00. 1h.. \$3.00.

\section{SPINACH}

Round Leaved-Plit., se; n\%., 10e; 1/4 lb., 1.te; lb., 30c.

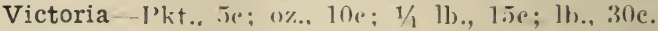




\section{WINTER Flowering and Ornamental PLANTS}

\section{FOR THE HOUSE AND CONSERVATORY}

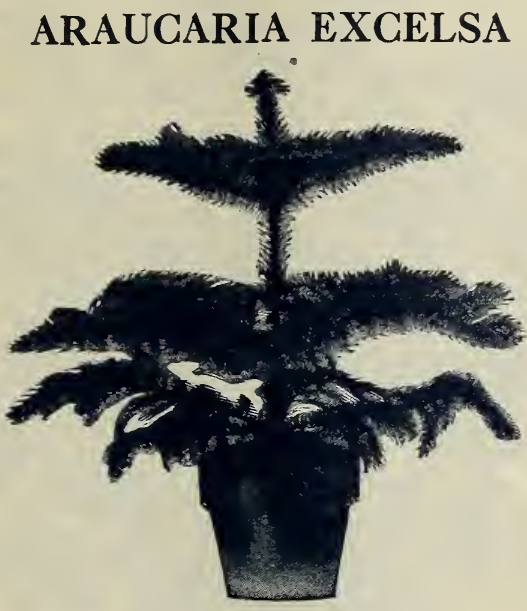

Frequently called "Norfolk Island Pine," or "Christmas Tree Palm.", With its deep green foliage arranged in symmetrical whorls, it makes one of the most handsome ornamental plants, and seems to flourish under all conditions.

5 -inch pots, 12 inches high............. 00 6 -inch pots, 12 to 15 inches high............ 150

\section{ASPARAGUS}

Brilliant, dark green foliage plants, unquestionably the most used of any indoor trailing plants for bracketed pots, window-boxes and hanging baskets.

Plumosus Nanus-The lace-like texture of its foliage outclasses Maiden Hair Fern for grace and daintiness; the long sprays being indispensable for floral decorations. Excellent alone or as center plant in jardinieres.

Sprengeri-Dense, gleaming trails, yards long. Very imposing, massed by itself in large cemetery urns. 10c each; 75c per doz.

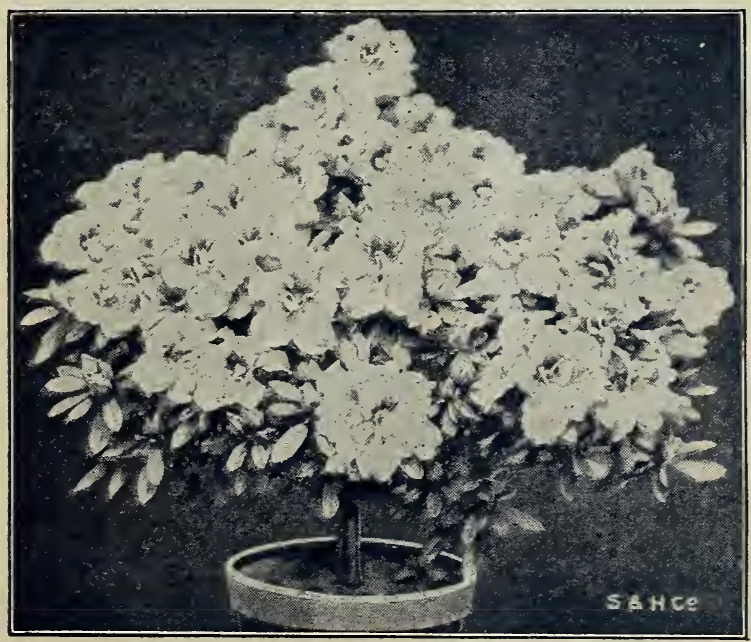

CHINESE AZALEA.

\section{CHINESE AZALEA}

We are large importers of these plants, and our collection is very complete, comprising the most distinct and best varieties in eultivation in all shades of crimson, pink, white, rose color and variegated. They arrive in October and may be had in bloom throughout the last of winter and early spring. Must be sent by express.

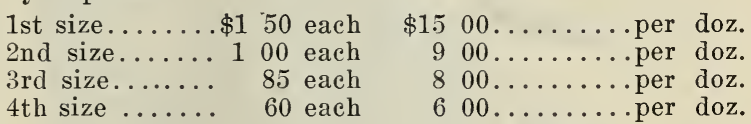

\section{BOXWOOD}

(Ready to Ship Last of November.)

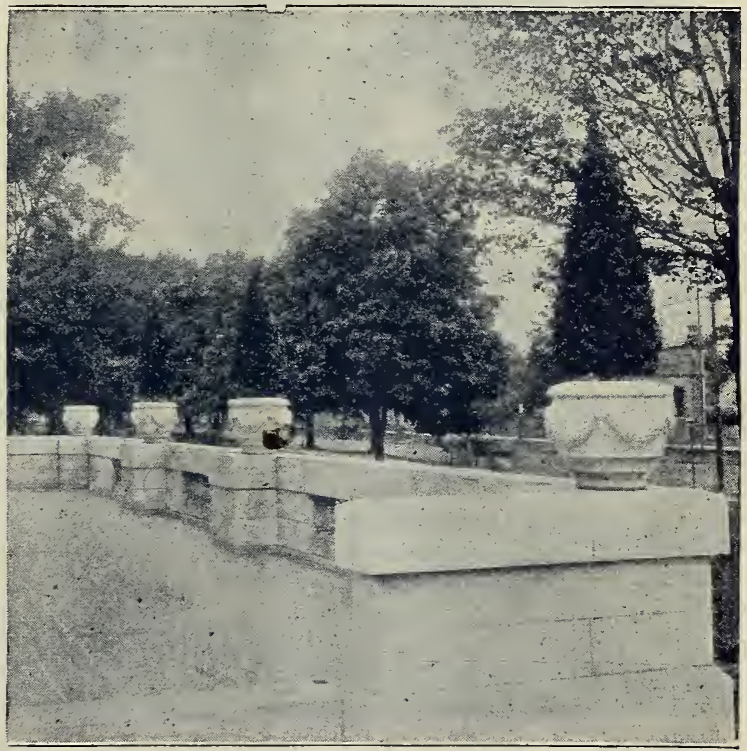

The increasing demand for Boxwood trees by people who appreciate their value in decorating halls, windowbays and conservatories in winter, or their verandas and lawns in summer, necessitate our importing them in great numbers. We offer a fine lot this year in graded sizes. Must be sent by freight or express.

Bush Shape-10 to 12 inches at $35 \mathrm{c} ; 12$ to 15 inches at $50 \mathrm{c} ; 15$ to 18 inches at $75 \mathrm{c} ; 24$ to 30 inches at $\$ 2.50$.

Pyramidal-3 feet at $\$ 2.50 ; 31 \frac{1}{2}$ feet at $\$ 3.50 ; 4$ feet at $\$ 5.00$.

\section{BEGONIAS FLOWERING VARIETIES}

Flowering Begonias seem to be especially suited to winter use; their clean, waxy foliage and bright flowers making a continuous show throughout the entire season, and assuming an importance and popularity unequalled by any other class of house plants.

Alba Picta-Leaves glossy green, thickly spotted with silvery white; flower white.

Argentea Guttata-Purple bronze leaves, oblong in shape with silvery markings, white flowers. 


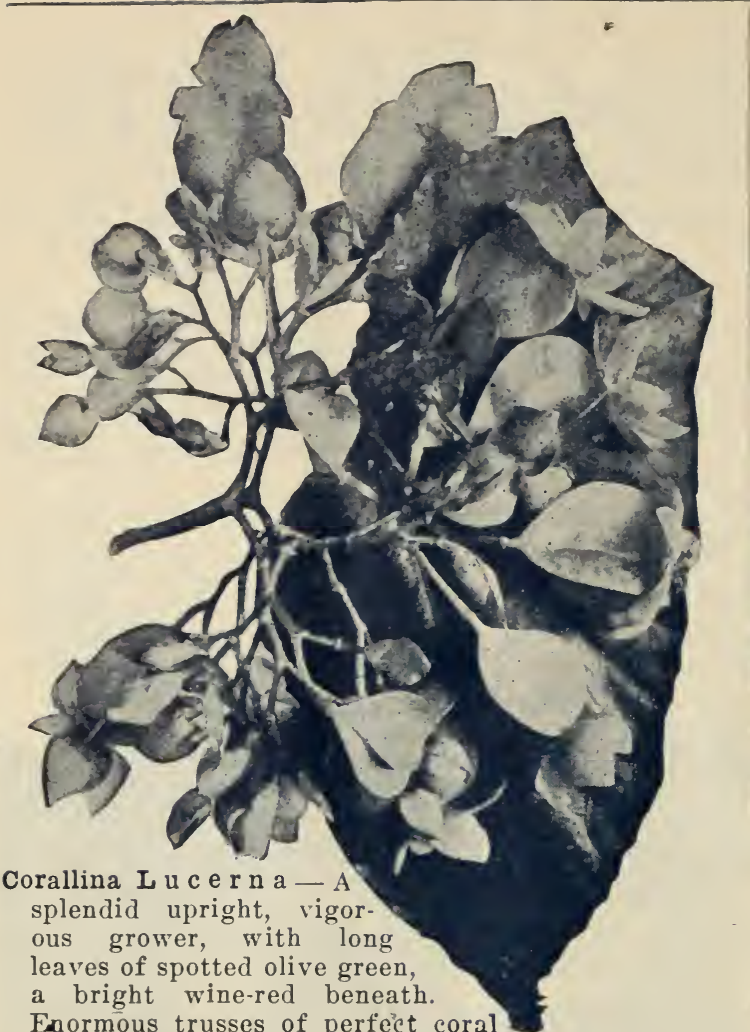

red flowers make this variety one of the showiest and most desirable kinds in cultivation. $25 \mathrm{c}$.

Erfordia-Grows in symmetrical, compact form, with shining green foliage, continually covered with clusters of rosy salmon flowers.

Glaucophylla Scandens (Trailing Begonia)-A vigorous growing variety, producing its beautiful clusters of rich salmon-colored flowers from the axil of each leaf. Its drooping habit makes it a very desirable plant for hanging baskets. $25 \mathrm{c}$.

Incarnata-One of the best for cutting. Light carmine flowers on long stems. A free winter bloomer, valuable for holiday decoration.

Mad. de Lesseps-A strong growing sort with large smooth leaves showing a satin finish, dark green above, red beneath; the ivory white flowers being borne in very large panicles.

Manicata Aurea-Large, glossy leaves, beautifully blotched with creamy white, with carmine etchings in the mature leaves. Flowers delicate blush white on long stems. $25 \mathrm{c}$.

Nitata-Blooms in good sized clusters of large flowers; white, delicately flushed rose.

President Carnot-A strong growing variety, of stiff, upright habit; foliage large, upper side deep green, under side purplish red; flowers beautiful coral red in large pendant panicles.

Purity-The finest pure white Begonia grown.

Rubra-The flowers are a rich coral red, hanging in large pendant clusters.

Thurstoni-Under side of leaves a rich, purplish red, veinings prominent, the upper side bronzy green, shaded with crimson and olive. Flowers rosy white in large clusters.

Warscewici-The old fashioned "beef-steak" Begonia. Thick, rounded leaves of deep green, with red on reverse side.

Unless noted, 15c each; our choice 16 for $\$ 1.00$.

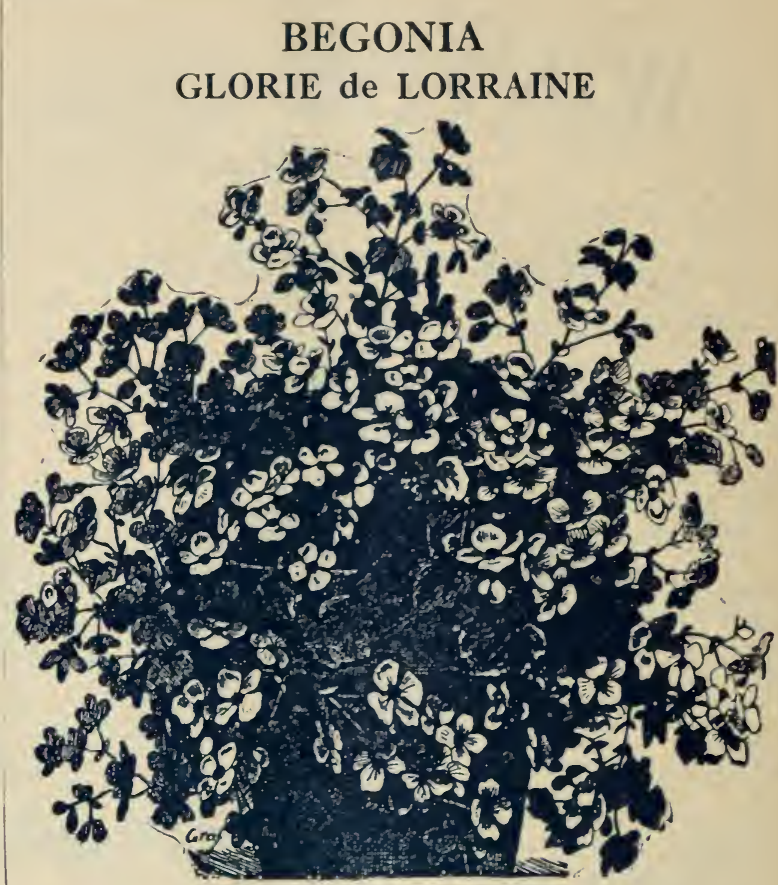

The most popular and one of the most beautiful Begonias for winter blooming; graceful, airy and fully flowered. Color bright pink. 4-inch pots, $50 \mathrm{c}$; 5 -inch pots, $\$ 1.00$.

\section{NEW BOUGAINVILLEA}

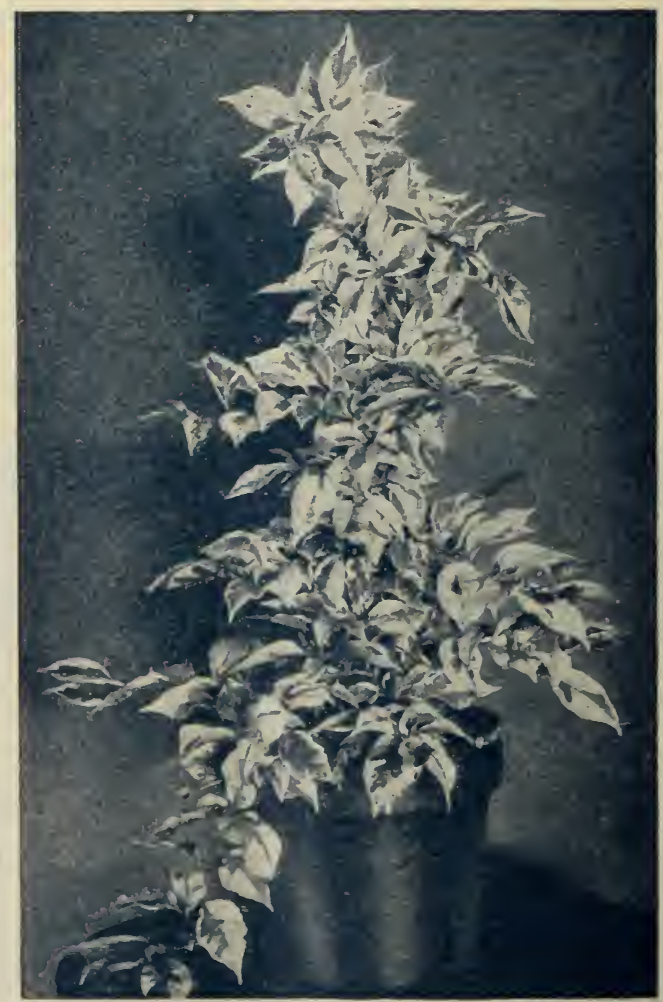

William K. Harris A handsome foliage variety; the clustered lanceolate leaves showing a sharply defined variegation of bright green and creamy white, in about equal proportions. Strong plants, 30c each. 


\section{CACTUS}

Epiphyllium Makoyianum (In bloom for Easter)-A beautiful variety of the Crab or Lobster Claw Cactus, with bright scarlet flowers of large size and unusually bright and showy. Must be sent by express; too large to mail. $50 \mathrm{c}$.

Epiphyllium Truncatum Violaceum (In bloom for Christmas) - An early flowering violet hued variety, with long drooping flowers. Blooms much earlier than Makoyianum and is, if possible, more beautiful. Must be sent by express. 50c.

\section{GARNATIONS}

We offer a select list of choice field grown plants, large enough for 5 and 6 -inch pots.

Enchantress-Delicate pink; one of the really grand Carnations. Long stems, large flowers and very prolific bloomer.

Rose Pink Enchantress-A true rose-pink shade of Enchantress. Practically identical in all other respects.

The Beacon-One of the finest scarlet Carnations; very large and free blooming.

Victory-A large flowered red; very showy.

White Perfection-A good free blooming white.

White Enchantress-One of the best whites yet produced, of pure quality, large size and immense production. Shape and habit closely follow the parent Enchantress.

By express, 20c each; $\$ 1.50$ per doz. (Cannot send by mail.)

\section{JERUSALEM CHERRY}

A bushy old fashioned plant whose chief attraction is the red or yellow, cherry-like fruit, which adorns it in great profusion for a long period during the winter. A favorite window plant. 4 and 5 -inch pot plants, 35 c each, by express.

\section{CHRISTMAS PEPPER}

Numerous conical peppers from 1 to $11 / 4$ inches long, colored in all shades and mixtures of purple, blue and red, make this a most attractive holiday decorative plant. By express, 4-inch pots, 35c each; 5-inch pots, $50 \mathrm{c}$.

\section{GLERODENDRON BALFOURI}

Should be trained to small trellis or staked up if grown as a pot plant in the house, when its branches will hang down, drooping gracefully with its bright flowers. A free bloomer, young plants a foot high often sending out several spikes of bloom. Flowers bright scarlet with calyx of creamy white. 4-inch pot plants, 25c.

\section{GROTONS}

Excellent decorative plants, gorgeously colored with different combinations of yellow, red, white and green. They are very easily grown and do well in any warm conservatory or window, and are particularly valuaible for bedding out in summer. $15 \mathrm{c}$ each; six distinct sorts for $75 \mathrm{c}$.

\section{GYPERUS ALTERNIFOLIUS}

\section{(Umbrella Plant.)}

A splendid aquatic plant, throwing up stems two to three feet high, surmounted at the top with a whorl of leaves. An excellent plant for growing in water or damp places, thriving in any good soil and always presenting a fresh, green, attractive appearance. $10 \mathrm{c}$ each; 4-inch pot plants, $25 \mathrm{c}$.

\section{DRACENA}

Godseffiana-A compact, shapely little plant with peculiarly marked foliage of a rich, dark green color thickly spotted with irregularly shaped dots of creamy white. $20 \mathrm{c}$.

Sanderiana-An upright, stocky variety that is very useful as a center plant in jardinieres, or to mix among the larger leaved foliage plants in the conservatory. Alternating lanceolate leaves of dark green prettily variegated with creamy white stripes. $25 \mathrm{c}$.

Terminalis-One of the most beautifully colored of all Dracenas. Leaves rather long and pointed, crimson, marked with pink and green and occasionally streaked with white. $35 \mathrm{c}$; larger by express, 50c.

\section{F E R N S}

There is no decorative plant more generally useful than a good Fern, in the brightening up of winterclosed rooms. It brings a grateful translation of sum. mer's verdure into our lives, and is thus as beautiful by suggestion, as in its own grace and color and exquisite symmetry. We offer a few of the latest and most popular varieties, any one of which is a gem in its class.

\section{BOSTON FERN}

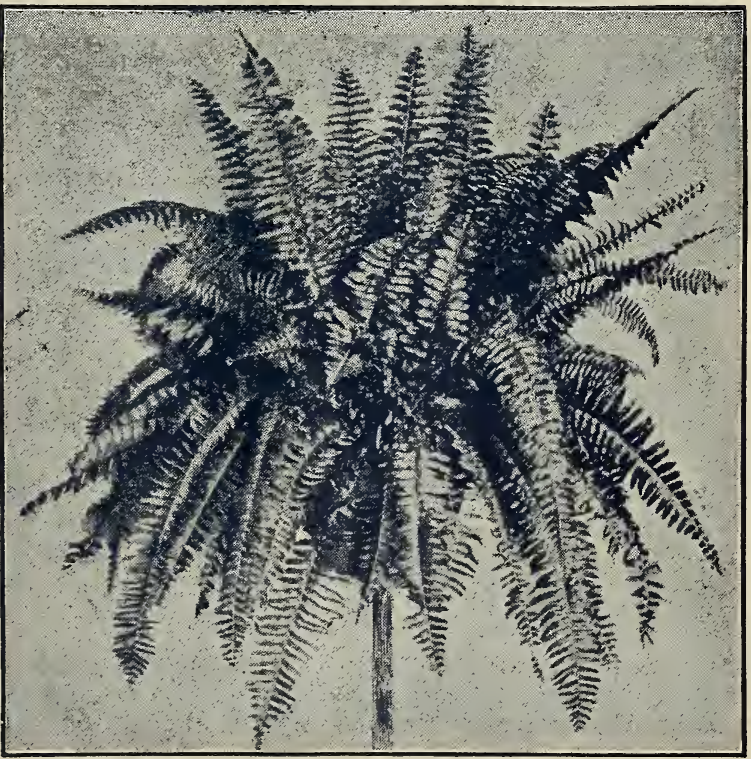

The original "Fountain Fern." Fully matured fronds often attain a length of four feet. $10 \mathrm{c}$ each. 4-inch pots..........30c 5 -inch pots..........50 7 -inch pots......\$1 00

\section{NEPHROLEPIS SCHOLZELI}

\section{(The Plumed Scott Fern.)}

A new sort representing the short, bushy, compact habit of N. Scotti, with foliage of the Ostrich Plume type. The smallest saleable plants perfectly express the type, and in every size are models of beauty for table decoration. 25c. By express, 4-inch pot plants, $50 \mathrm{c} ; 5$-inch pot plants, $75 \mathrm{c}$. 


\section{NEPHROLEPIS WHITMANII}

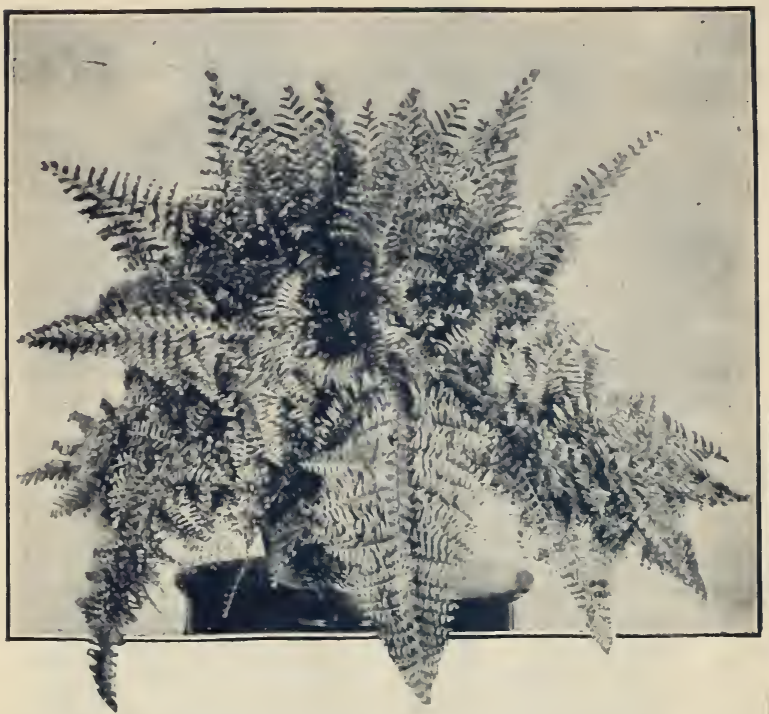

The graceful pluminess and charm of this new Nephrolepis, with its characteristic features of shape, size and growth, give it distinguishment and superior commercial value. Whitmanii is of dwarf growth and wide stocky shape. The fine cut fluffy fronds stand erect, and have proved little liable to revert to the original Boston type. 20c.

By express

4-inch pots. .

5 -inch pots.......50e

\section{NEPHROLEPIS SCOTTI}

(The New Dwarf Boston Fern.)

A compact dwarf form of the favorite Boston Fern, in general appearance very much like the original form, but more compact, making well finished, shapely specimens even in the smaller sizes. $21 / 2$-inch pot plants, 15e.

Larger by express:

4-ineh pots........50e

j)-inch pots........75e

\section{ADIANTUM GROWEANUM}

The new improved Maiden Hair Fern.

4-inch pot plants, by express.

6 -inch pots-beautiful specimens

\section{MOSS FERN}

(Selaginella or Lycopodium.)

Emiliana-A good substitute for Asparagus or Maiden IIair Fern in filling Fern dishes, or for table and house decorating in larger sized pots. $15 \mathrm{c} ; 2$ for 25 e.

\section{SMALL FERNS FOR DISHES}

Aspidium Tsussimense-A pretty dwarf species. 15e. Pteris Adiantoides-A strong growing variety with broad, glossy, deep green foliage.

Pteris Alexandraea-Nicely variegated green and white, each frond crested at the ends.

Pteris Argyrea-A very showy, strong growing Fern, variegated foliage; fronds large, light green, with a broad band of silvery white down the center of each; very distinct. $15 \mathrm{c}$.

Pteris Cretica Albo-Lineata-A handsome dwarf growing Fern; deep green, striped white.

Pteris Magnifica-Beautiful crested fronds.
Pteris Mayii-A dwarf variegated sort, with ends prettily erested.

Pteris Serrulata-A useful basket variety of graceful habit.

Pteris Tremula-One of the finest Ferns for house decoration, growing very rapidly and throwing up large, handsome fronds; makes magnificent specimens; easily grown and very popular.

Pteris Wimsetti-Artistically irregular fronds.

Unless noted, 10c each.

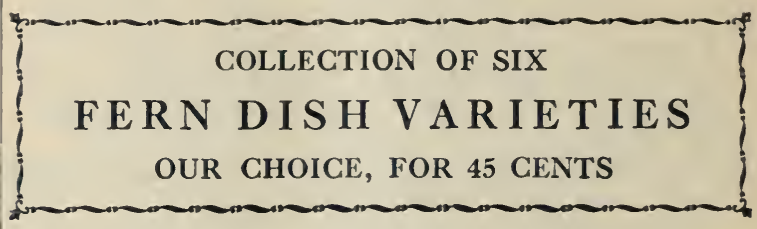

\section{FICUS}

(Rubber Plant.)

Elastica (India Rubber Tree)-Nothing better for table or house decoration. Its dark green, shiny foliage is always handsome, and its constitution is such that it is able to stand the excessive heat and dryness of the ordinary dwelling house without injury. $35 \mathrm{c}$.

Pandurata (Majestic Rubber Plan t)The odd construc. tion a nd mammoth leaves of this new decorative $\mathrm{pl}$ a $\mathrm{n} t$ make a very stril: ing aproarance. The leaves are guitars h a ped with the larger end out, stiffly uprising from the central stalk. They are very thick and rubbery, ten inches wide by fifteen in. ches 1 o n g; d a r k green, with creamy white veins, which on the underside are purple and boldly projecting. The sizes we offer are fine specimens, by express, 18 to 20 inches high, $\$ 1.00$ each; 24 to 30 inches high, $\$ 2.00$

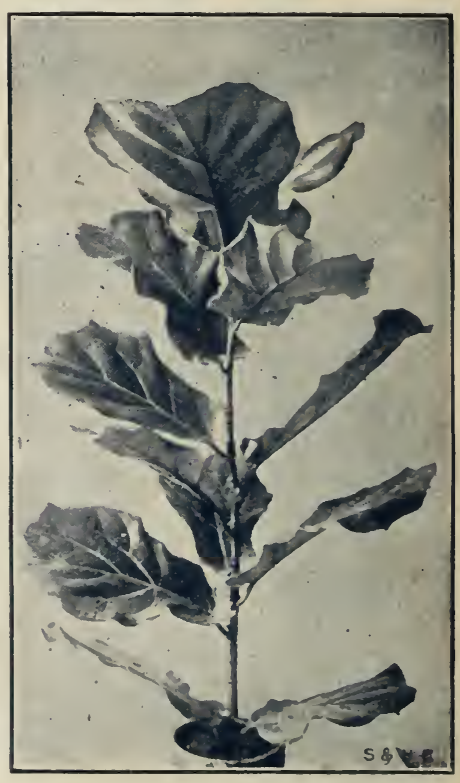

\section{GENISTA RACEMOSA}

A compact, fine leaved, shrubby plant, very useful for winter decoration; its profuse bloom making a rich show of golden yellow. 20e. Strong 4-inch pots, $35 \mathrm{e}$; 5-inch pots, $50 \mathrm{c}$.

\section{GREVILLEA ROBUSTA}

The "Silk Oak" is a stately decorative plant of great beauty and service. The foliage is bright green with silvery reverse, as finely eut and graceful as a Fern. 15c.

\section{ENGLISH or PARLOR IVY}

One of the very few good climbing vines for the

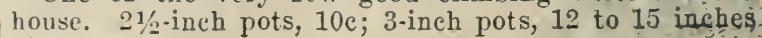
high, 25c. 


\section{LEMON “PONDEROSA"}

(or “'American Wonder.')

A fragrant breath of the South translated $\mathrm{i} \mathrm{n} \mathrm{t} \mathrm{o}$ $\mathrm{N}$ o $\mathrm{r}$ t h e r $\mathrm{n}$ homes. $\mathrm{T} h \mathrm{e}$ d a $\mathrm{r} k$ glossy foliage winters well and is always verdant, the attractive flowers of pure white with yello w stamens are refreshing in their waxen beauty a $n d$ subtle perfume, while $\mathrm{t} h$ e i $\mathrm{r}$ crowning glory is the fruit. $\mathrm{F}$ i $\mathrm{v}$ e or $\operatorname{six}$ times as large as the ordinary Lemon of commerce; of per-

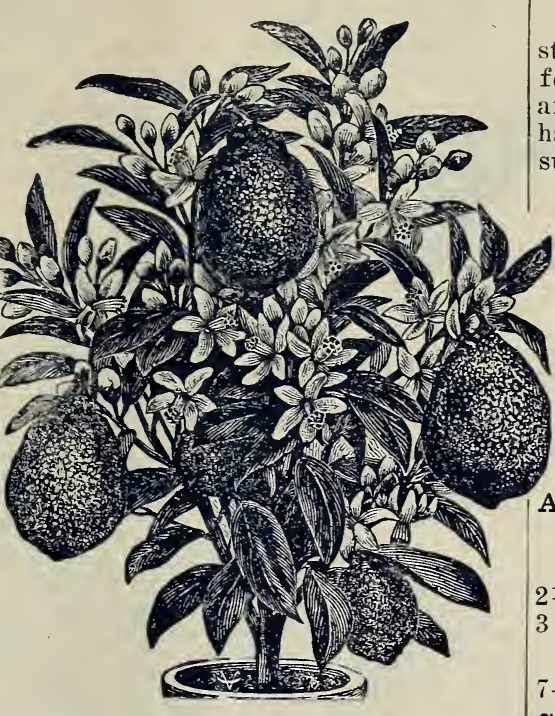

fect shape and even ripening-Ponderosa represents the highest quality as a fruit, while the combination of flower, fragrance, fruit and tree-like growth makes it one of the grandest and most satisfactory window and porch decorative plants in existence. 15c each. Larger plants by express, 15 to 18 inches high, 50c.

\section{OTAHEITE ORANGE}

The best Orange for pot culture. Plants dwarf and symmerical in form. Flowers freely with a delightful Orange fragrance. Fruit edible; about half the size of ordinary Oranges. A grand plant for winter culture; scarcely ever without some display of blossoms or fruit. $15 \mathrm{c}$ each, 4 for 50c. Larger specimens, by express, $35 \mathrm{c}$.

\section{MARANTA}

Bachemiana-Lance-shaped leaves of rich green, beautifully marbled silvery white. Stands well in warm rooms, retaining foliage and undiminished color indefinitely. 4-inch pots, $50 \mathrm{e}$ each.

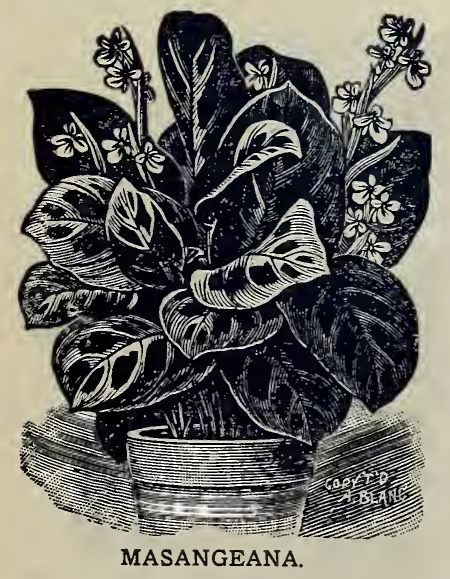

M a s a nge an aDwarf growing plant with light green foliage mottled maroon, always bright and attractive. Used extensively i $n$ filling $\quad \dot{\mathrm{F}}$ e $\mathrm{r}$ n dishes, and combines well with other plants in decorating. $20 \mathrm{c}$.

Rosea Lineata-A strong, upright growing p l a nt with leaves 6 to 10 inches long and 2 to 3 inches wide. The stems and under side of leaf are red, the upper leaf surface being beautirully lined with narrow stripes of white and delicate pink. Four-inch pot plants, 50e each.

\section{PARROT'S FEATHER}

(Myriophyllum Proserpinacoides.)

A novel aquatic hanging plant. Its long trailing stems are clothed with whorls of the most exquisite foliage, as finely cut as the leaves of the Cypress Vine, and much more delicate. Planted in a water-tight hanging-basket, so water ean be kept standing on the surface, it will trail finely. $10 \mathrm{e}$ each; $\$ 1.00$ per doz.

\section{PALMS}

We make a specialty of Palms, and have one of the largest and best stocks of them to be found anywhere.

NOTE-Where height of plant is given, it means height from top of pot.

ARECA LUTESCENS-Glossy green leaves gracefully curved on slender stems.

MAIL SIZE.

$21 / 2$ inch pots $\ldots \ldots \ldots \ldots \ldots \ldots . .$.
3
inch pots, 10 inches high. $15 \mathrm{c}$ LARGER SIZES BY EXPRESS.

7 -inch pots, 24 to 28 inches high.

COCOS WEDELLIANA-A strikingly handsome little plant used for small jardinieres and in fern dishes to a great extent. Six to seven inches high. 25c.

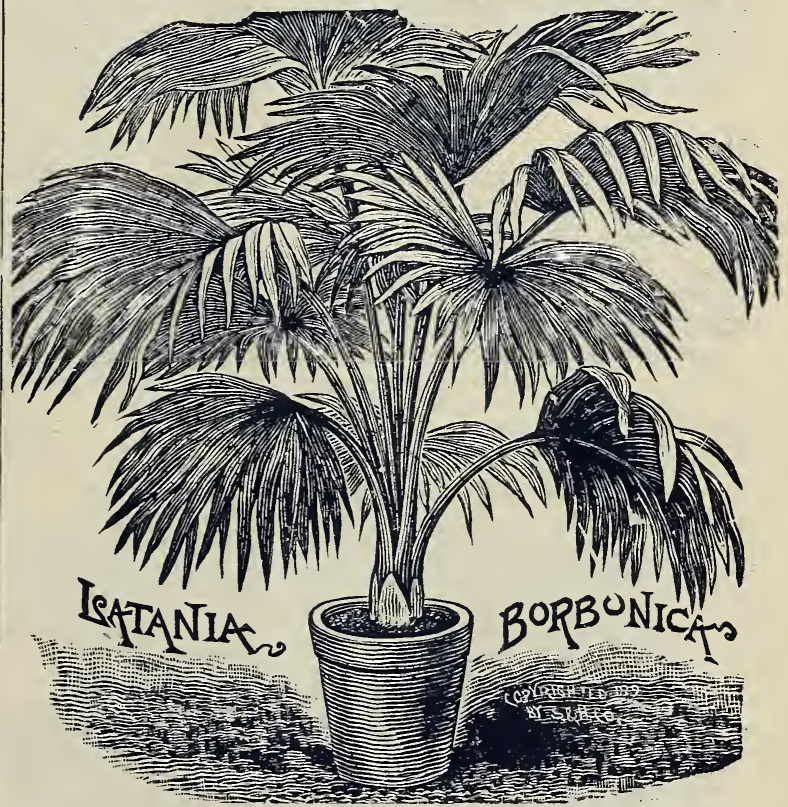

LATANIA BORBONICA (Fan Palm) - A beautiful Palm, with large, broad, deeply divided, fan-shaped leaves.

inch pots .........................

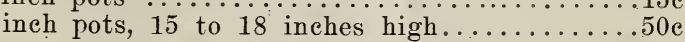

LARGER SIZES BY EXPRESS.

7 -inch pots, 20 inches high, strong.....\$1.50 each PHOENIX ROEBELENII-A very dainty Palm, as light and feathery as a Cocos, but as hardy as a Kentia. Will be found the correct thing for small jardiniere or fernery.

4-inch pot plants, 8 to 10 inches high.......75c each 5 -inch pot plants, 12 to 15 inches high.......\$1.25 8-inch pot plants, 15 to 18 inches high....... 2:50 


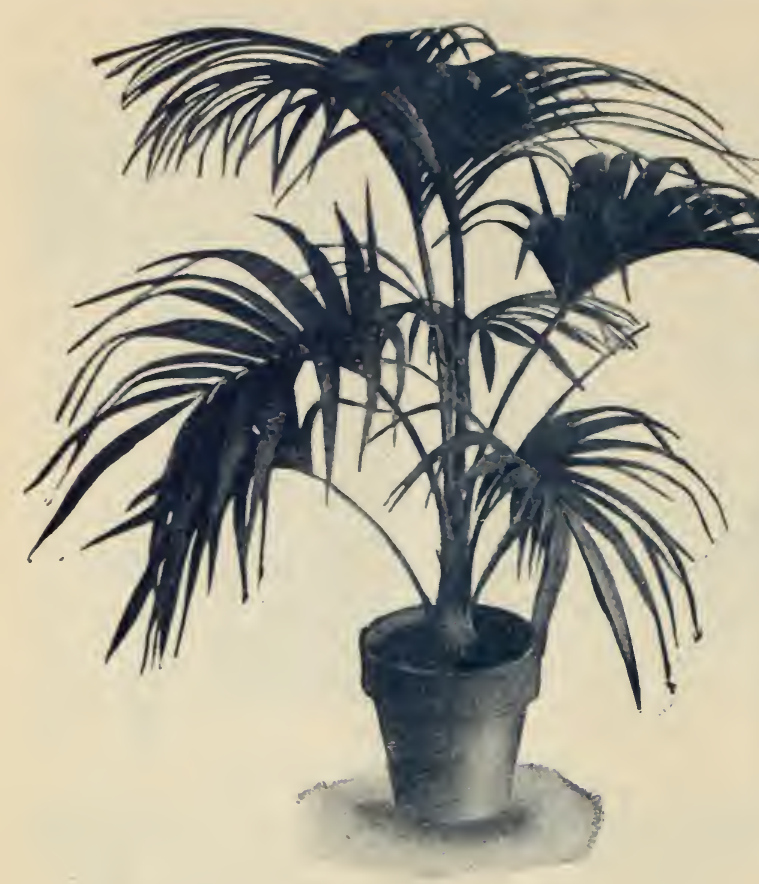

KENTIA BALMOREANA-This is, in our estimation, the very best Palm for house culture, as well as the most graceful and handsome. 'i here are few plants that give more satisfaction all the year round. MAIL SIZE.

$21 / 2$ inch pots

3 inch pots, 10 inches high. $.15 \mathrm{c}$ LARGER SIZES BY EXPRESS.

4-inch pots, 12 to 15 inches high........... .50 5 -inch pots, 15 to 20 inches high........... 1.00 7 -inch pots, 24 to 28 inches high.

KENTIA FORSTERIANA - Much like Balmoreana, but grows taller, with larger, heavier foliage.

MAIL SIZE.

$21 / 2$ inch pots

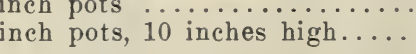

$.15 \mathrm{c}$

LARGER SIZES BY EXPRESS.

4-inch pots, 15 to 18 inches high.

5 -inch pots, 18 to 24 inches high.

6 -inch pots, 24 to 28 inches high.

7 -inch pots, 28 to 32 inches high.

8 -inch pots, 32 to 36 inches high.

\section{PANDANUS}

Veitchi - Gracefully curved foliage, light green striped with broad bands of pure white. An attractive decorative plant that stands ordinary house culture well and is always fresh and bright in appearance. Large plants from 5-inch pots, by express, $\$ 1.00$ each.

Utilis (Screw Pine)-A grand decorative plant. Its glossy dark green foliage, gracefully arranged, renders it particularly attractive; fine for centers of vases or baskets, or for growing as single specimens. Nice plants, $2 \frac{1}{2}$-inch pots, $20 \mathrm{c}$.

\section{PRIMULA-Primrose}

Chinensis (Chinese Primrose)-We have this in three separate colors, crimson, pink and white. By continued repotting into larger pots will make beautiful specimens in bloom. A handsome effect may be obtained by placing three or four in a six or eightinch pot. $10 \mathrm{c}$ each; 3 for $25 \mathrm{c}$; $75 \mathrm{c}$ per doz.
Forbesi-(Baby Primrose)-The smallest flowered of all Primroses, but one of the most striking little plants imaginable. Blooms practically all the year with good sized trusses of dainty little rosy lilac flowers. 10e each; 3 for $25 c$; 75 e per dozen.

Obconica Gigantea-Almost a perpetual bloomer. May be expected to give good show of bloom all winter. Separate colors, Crimson, pink and lilac. 10e each; $\$ 1.00$ per dozen.

\section{SANSEVERA ZEALANICA}

An ideal decorative plant; will stand more hardship and abuse than any other house plant of which we know. Leaves thick and of leathery texture, not affected by gas, dust or heat. Grows to a length of 3 to 4 feet, and is beautifully striped crosswise of leaves with broad white variegations on a dark green ground. $20 \mathrm{c}$.

\section{SMILAX}

A very graceful climber, possessing the rare qualities of delicate and dense foliage and rining habit, admirably adapting it to elimbing or drooping. It is fine as a parlor or window plant. $10 \mathrm{c}$.

\section{SWAINSONIA}

Galegifolia Alba-A popular ever-blooming house plant, blooming in sprays of 10 to 20 flowers shaped much like Sweet Peas. Its pure white flowers are used extensively in cut flower work. 15c.

\section{FIELD GROWN VIOLETS}

California-The plant is a robust grower with dense, heavy foliage, entirely free. from the disease that is so destructive to the other sorts. Flowers single, intensely fragrant. Color, a clear, violet purple that does not fade. The flowers are very large and borne on stems ten to twelve inches long, giving them unusual value for cut flowers. 15e.

Princess of Wales-Broad Pansy-like flowers of a beautiful violet purple shade, with lighter center. A vigorous growing plant with clean healthy foliage and stiff long stems. One of the most beautiful and free flowering violets. $15 \mathrm{c}$.

Swanly White-Flowers large, double, pure white. 15c.

By express, \$1.50 per doz.; \$10.00 per 100 .

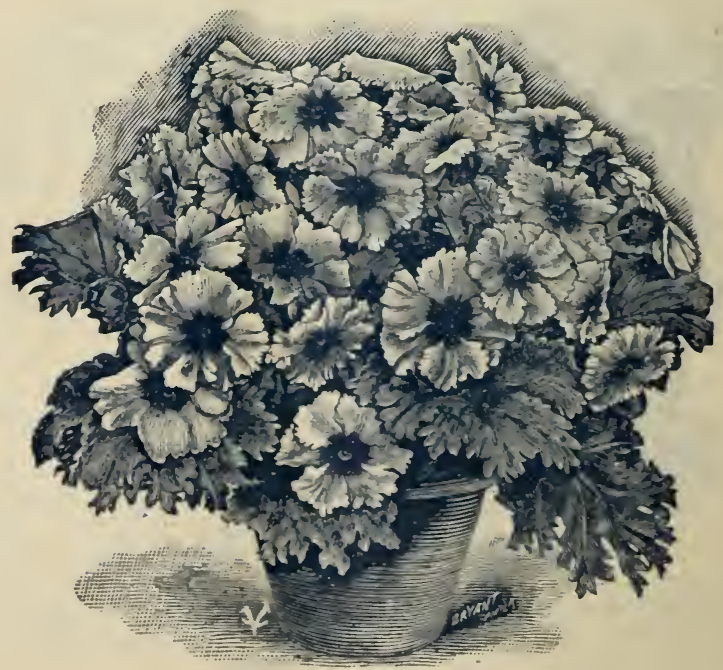

PRIMULA CHINENSIS. 


\section{6 $\mathrm{R} O \mathrm{OES}$}

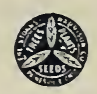

In preparing a Rose Bed, select a sunny location guarded from cold north winds, if possible. Dig out the beds to a depth of two or three feet and about three feet in width; then refill the trench with a mixture of soil (any good fertile soil will do) and well rotted cow manure, making provision for good drainage if location is not naturally drained. Time should be allowed for this filling to settle, the final top surface being an inch or two below the edges of the bed. Do not raise the surface of Rose beds above the surrounding surface. They suffer less from drought when left level with the turf.

Plant your roses in the center, being very particular to press and tamp the soil firmly around the roots; and soaking the bed thoroughly at the finish. The Everbloomers may be set 18 inches apart, the Hybrid Perpetuals about 2 feet. After the plants have been set out, keep the soil loose to the depth of an inch or two, by frequent stirrings. An occasional soaking with weak manure water is a great help to roses of all sorts.

Protect for the Winter by covering bed at least 6 inches with leaves or manure; a binding surface of dirt, cornstalks or boughs on top. A convenient method is to confine this dressing by an enclosure of 12 inch chicken wire.

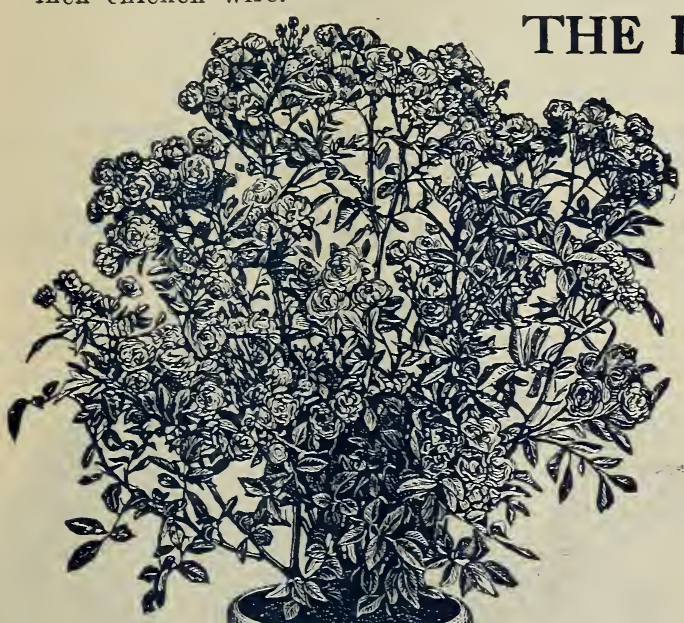
HYBRID POLYANTHAS $\underset{\text { RAMBLERS" }}{\text { Or }}$

This charming class of roses are the sensation of the last few years. They represent the triumph of productive effort among rose growers in bringing the vivid colors, prodigal freed om and beautiful clustering form of the grand outdoor Rambler roses into the house for winter decoration. Equally attractive for outdoor bedding.

Crimson Baby Rambler-The original of the group, dwarf, bushy, profusely blooming; its compact clusters of bright crimson flowers continuous indoors and out. $10 \mathrm{c} ; \$ 1.00$ per doz.; 2-year plants, 35c; $\$ 3.50$ per doz.

'Baby Dorothy', (Pink)-A true dwarf form of Dorothy Perkins, continuing the family virtues, and pink beauty. The prettiest pot rose on the market. $20 \mathrm{c} ; \$ 2.00$ per doz.; 2 -year plants. $50 \mathrm{c} ; \$ 5.00$ per doz.

White Baby Rambler-As delicately tinted and as full of clusters as any Polyantha Rose. Its pure white flowers are perfectly double, and bloom with the unceasing freedom of the reds and pinks of this class. $15 \mathrm{c} ; \$ 1.25$ per doz.; 2-year plants, $35 \mathrm{c} ; \$ 3.50$ per doz.

BABY RAMBLER.

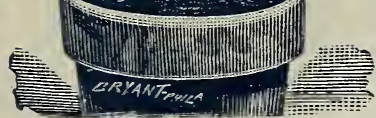
strong, two-year plants, $50 \mathrm{c} ; \$ 5.00$ per dozen.

One each of these 4 sorts, 1 year old plants, for 50c; 2-year plants, 1 each, for $\$ 1.30$.

\section{HARDY ROSES For Permanent}

\section{HYBRID PERPETUAL ROSES}

These are the "June Roses," so admirably suited for garden culture, the formation of Rosebeds, hedges, etc. In May and June, these lovely Roses are brilliant with large, perfumed flowers of richest colors, far exceeüing the Everblooming class in size and vivid effect. Some rarieties bloom late in summer and even into autumn.

They luxuriate in a deep rich soil, and are benefited by mulching with leaves or strawy manure in fall. Prune according to habit of growth, cutting back close all weak shoots and shortening the long canes to a convenient length.

Alfred Colomb-Bright carmine crimson; one of the very best dark colored sorts.

Anna de Diesbach-Brilliant rose color.

Baron de Bonnstetten-A splendid shade of dark red, changing to velvety maroon.

Clio-Color, delicate satin blush, with a light shading of rosy pink at the center.

Coquette des Alps-White, sometimes faintly tinged with pale blush.

Coquette des Blanches-Fine form, pure white.

Eugene Furst-A beautiful, velvety crimson, with distinct shading of crimson maroon.

Francois Levet-Large, bright clear rose color.

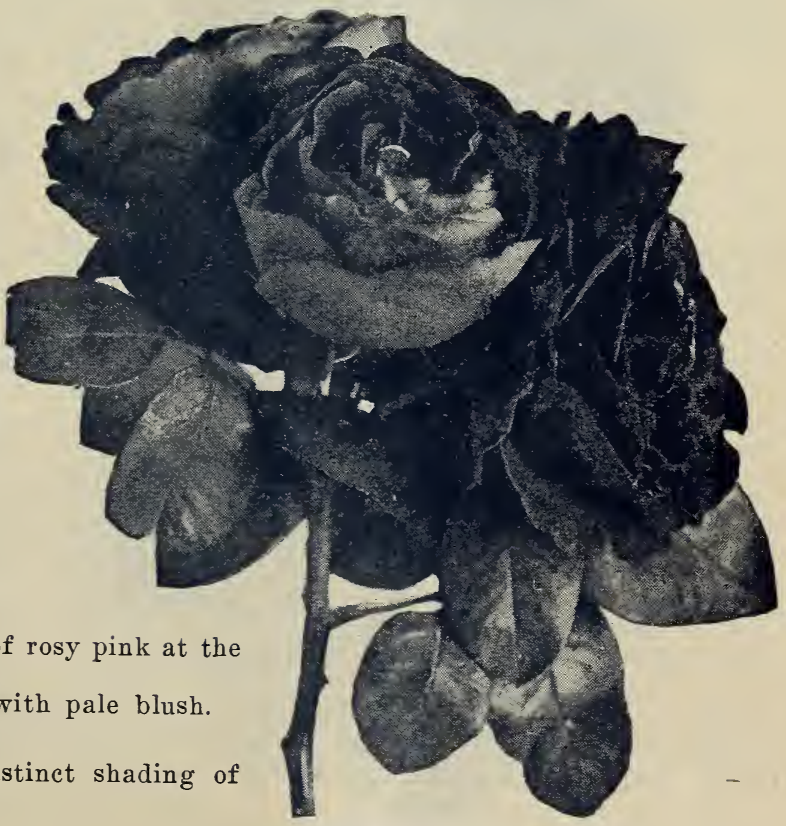

EUGENE FURST. 


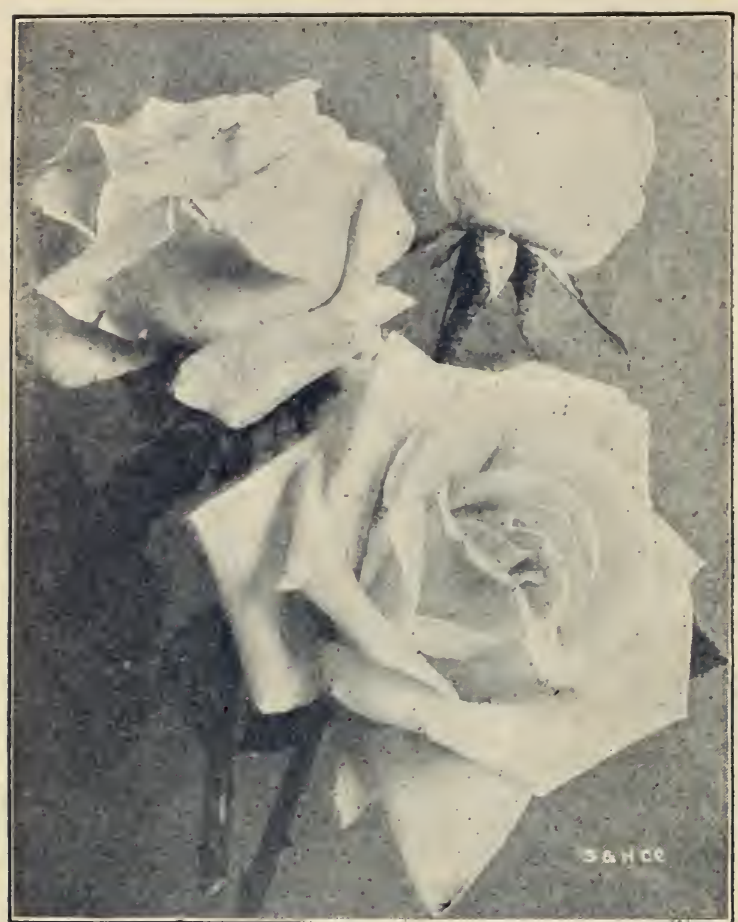

FRAU KARL DRUSCHKI.

Frau Karl Druschki-A pure paper-white, large sized and free flowering. The bloom is perfect in form on fine, long stems. 50c each.

General Jacqueminot-Holds first place among the dark red Roses. Rich crimson scarlet.

Glorie de Margottin-Dazzling crimson.

Hugh Dickson-Magnificent crimson, shaded scarlet. Large and double. $50 \mathrm{c}$ each.

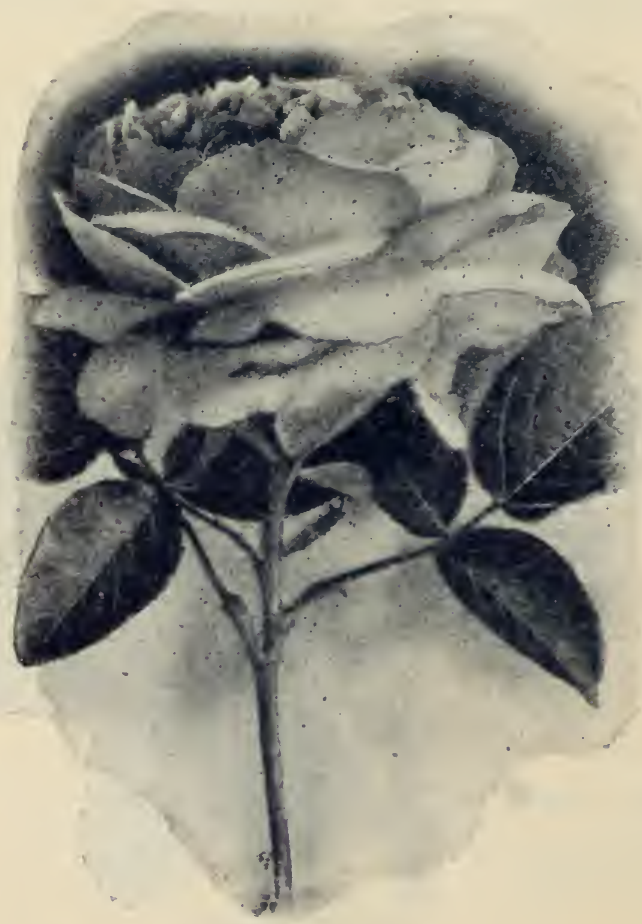

PAUL NEYRON.
John Hopper - A beautiful dark pink.

Jubilee-Pure red, shading to crimson and maroon at the base of petals.

Jules Margottin-Bright cherry-red.

Margaret Dickson-Large flowered and extra vigorous. Its large petals are thick and shell-shaped, of good substance; white tinted with flesh next the center. Foliage dark and rich, displaying to advantage the lovely blooms.

Marshall P. Wilder-Bright cherry carmine, very fragrant; one of the freest bloomers.

Mrs. J. H. Laing-A grand sort, with fine flowers of soft, delicate pink, with satin cast.

Paul Neyron-The largest flower of any Rose in cultivation, often 5 inches in. diameter; color, deep clear rose, very fresh and attractive.

Prince Camille de Rohan-Very dark velvety crimson, changing to intense maroon.

Ulrich Brunner-Cherry red.

Vick's Caprice-Soft pink, striped carmine.

Strong out-door grown dormant plants. Unless noted, 35c each; $\$ 3.50$ per dozen; by express, $\$ 20.00$ per 100 .

\section{HARDY CLIMBING ROSES}

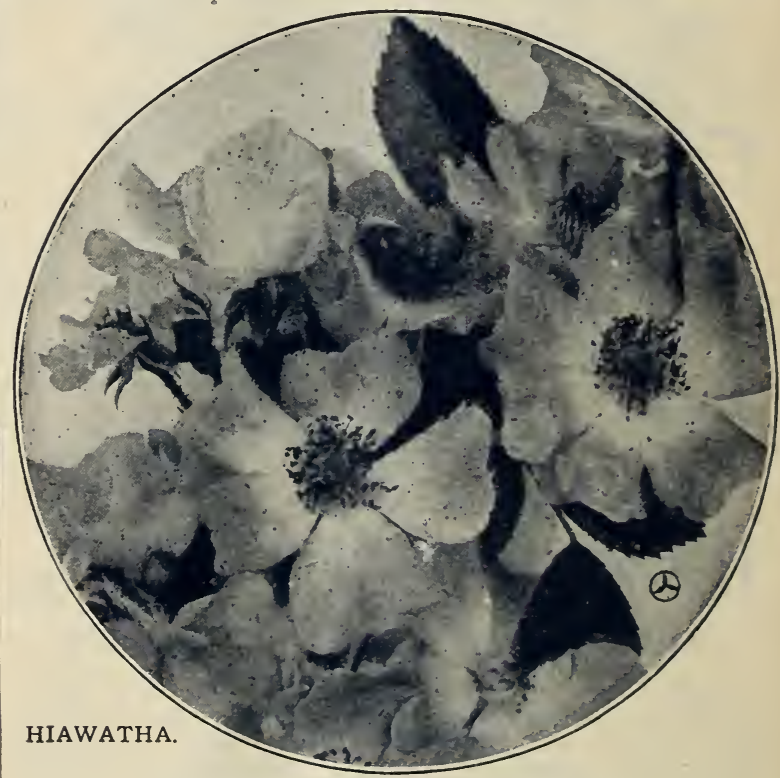

NEW HARDY CLIMBERS

Hiawatha-Distinctly different from other Ramblers. Its small flowers-(leep ruby crimson, accentuated by a white eye-are uniquely borne in long trails of 40 to 50 blooms.

Newport Fairy-Very pretty clusters of bright rose colored flowers; a good strong climber, with clean and brilliant foliage.

Tausendschon-A rapid growing, almost thornless climber, showing the blood of Rambler, Polyantha and Tea parentage. Its innumerable flower clusters make a pretty show through. June and July; at first, the soft pink of Clotilde Soupert and later, deepening to a bright carnine rose.

Trier-Semi-double, produced freely and continuously in large clusters of creamy white; the center being filled with bright yellow anthers so long and numerous that at a distance the Rose appears yellow.

Field grown plants, 50c each; $\$ 5.00$ per dozen. 


\section{CRIMSON RAMBLER.}

The famous crimson clustered climber, so extremely effective when grown on pillars and trellises. $10 \mathrm{c}$; 3 for 25c. Strong two-year, field grown plants, 30c each; $\$ 3.00$ per doz.

\section{DOROTHY PERKINS.}

A beautiful shell-pink; foliage finer, smoother and darker than Crimson Rambler. 15e; 3 for $30 \mathrm{c}$. Strong two-year, field grown plants, $35 \mathrm{c}$ each; $\$ 3.50$ per doz.

\section{LADY GAY.}

A splendid new variety of the Rambler type, hardy, healthy and free blooming in every climate. The buds are a bright cherry pink, the open flowers soft white, and the leaves a deep waxy green, making a very charming combination of colors. $21 / 2$-inch, $15 \mathrm{c}$ each; field grown, 35c each; $\$ 3.50$ per doz.

\section{GENERAL COLLECTION.}

Baltimore Belle-Very double blush white.

Empress of China-Bright pink flowers; practically everblcoming:

Leuchtstern-This variety resembles Crimson Rambler in foliage and habit, bearing large clusters of single flowers, bright rose with a distinct white eye.

Multiflora Japonica-Clusters of pure white.

Philadelphia-Perfectly double, of a pure deep rich crimson, by far the most intense of any Rambler Rose.

Pink Rambler-Often changing to creamy white.

Prairie Queen-Always popular. Bright rosy red.

Rubin-Surpasses Crimson Rambler in size of flowers and depth of coloring; Rubin being a dark red or ruby.

Ruby Queen-Deep ruby red, with shiny, leathery foliage.

Seven Sisters-Crimson, changing all shades to white. White Rambler (Thalia)-Constant white.

Yellow Rambler-Light canary shade; clusters smaller, individual flowers larger than Crimson Rambler.

Strong two-year, field grown plants, 25c; $\$ 2.50$ per dozen.

\section{MOSS ROSES}

The Moss Rose is as hardy as any rose can be, and an extra vigorous grower. They are much admired on account of their bright, healthy foliage and moss like covering of the buds. While they bloom but once a year, the flowers are large, beautiful and plentiful. Blanche Moreau-Pure white, large and full.

Countess of Murinais-Large pure white, beautifully mossed.

Henri Martin-Large, globular flowers, full and sweet; rich, glossy pink, tinged with crimson.

John Cranston-Deep crimson, very double.

Luxemburg-Bright erimson; beautifully mossed.

Princess Adelaide-Fine large flowered; very double and fragrant; color bright rosy pink.

Strong two-year plants, 35c; $\$ 3.50$ per doz.

\section{JAPANESE GREEPING ROSES}

Rosa Wichuriana (Memorial Rose)-Handsome for covering rockeries, mounds or embankments; especially valuable for cemetery planting. The pure white single flowers appear in greatest profusion during the month of July, while its almost evergreen foliage makes it very desirable at all seasons of the year.

Strong two-year old field grown plants, 25c each; $\$ 2.50$ per doz.

\section{HYBRID WICHURIANA ROSES}

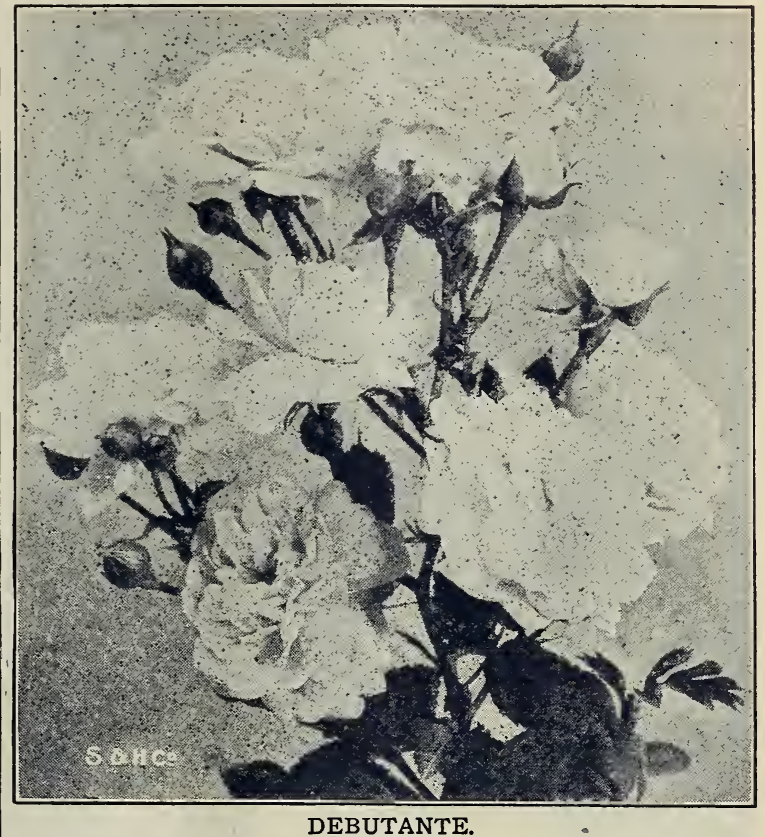

These Hybrids retain most characteristics of the old Wichuriana, but are much stronger growers and bloom more freely.

Debutante-White; Manda's Triumph-White; Pink Roamer-Pink; South Orange Perfection - Blush; Sweetheart-Pink; Universal Favorite-Rose. Strong two-year plants, 30c.

One each of six Hybrid Wichurianas, two-year-old, for $\$ 1.40$.

\section{ROSA RUGOSA and its Hybrids}

Rosa Rugosa Rubra-Foliage shiny bright green, flowers deep rose, produced in clusters. Beautiful red berries in autumn. 15c. Strong two-year plants, $35 \mathrm{c}$.

Rosa Rugosa Alba-Pure white. Field grown, 35c.

Agnes Emily Carman-Flowers large, semi-double, rich, deep crimson. Blooms long and profusely. $35 \mathrm{c}$. Field grown.

Belle Poitevine-Very free and branching, every tip laden with immense bouquets of large pink Roses. Buds very long; perfume exquisite. 35c. Field grown.

Blanc Double de Coubert-Purest paper white, blooming in clusters of from 5 to 10 flowers; double, very sweet. A strong, rampant grower, having the true Rugosa foliage. Flowers often measuring 5 inches in diameter. 35c. Field grown.

Conrad Ferd. Meyer-Flowers large, cup-shaped and double; of a delicate silvery pink. Strong twoyear, field grown, $50 \mathrm{c}$ each.

Mad. Georges Bruant-Semi-double pure white, produced freely in showy clusters, buds being long and pointed. Needs slight protection against zero weather. Field grown, 35c.

New Century-Flowers very large, full and double, borne in clusters; flesh-pink, with bright red center, all petals widely bordered with creamy white. Field grown, 35c.

Two-year-old field grown plants, set of eight for $\$ 2.50$. 


\section{HARDY PERENNIAL PLANTS}

For Permanent Planting in Borders or Beds

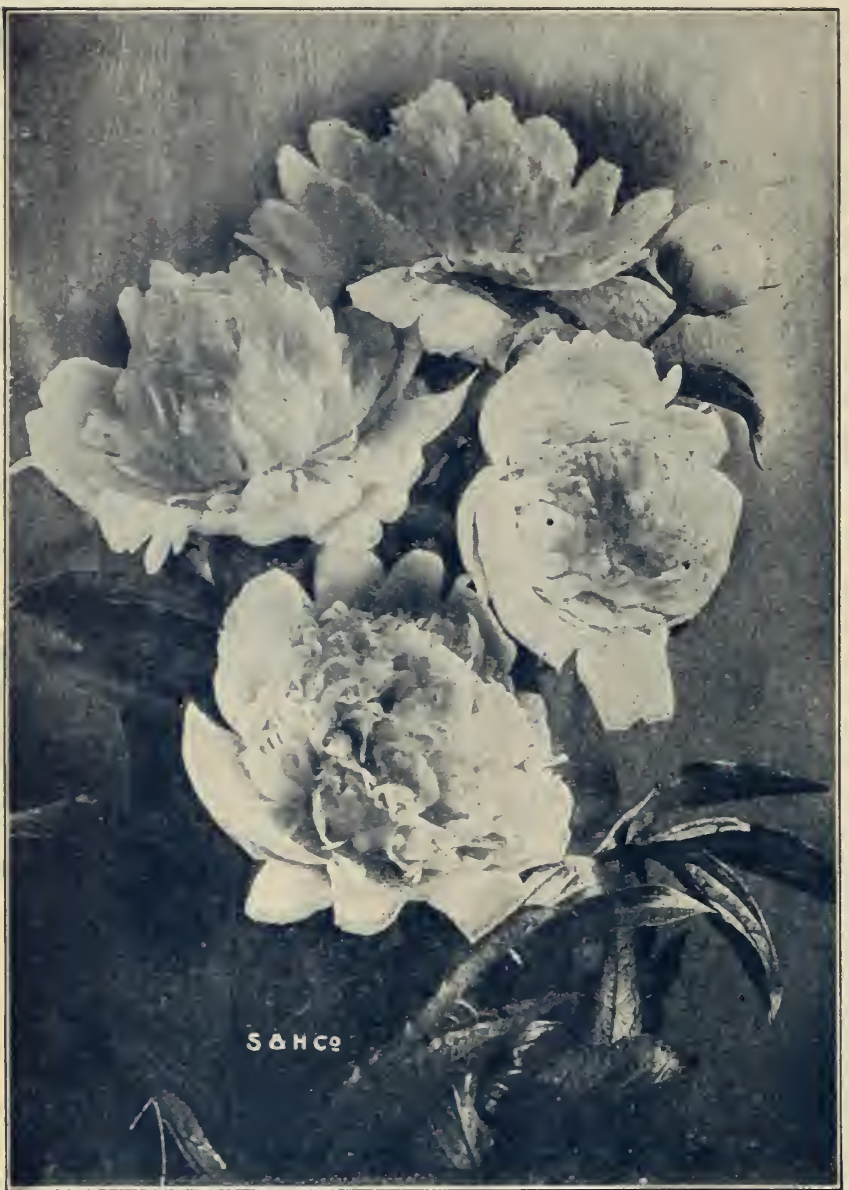

Berlioz (New)-Reverse of petals, and thus the buds, are dull rose color; but open up into broad, full flowers of the deepest crimson. Very free. 60e; $\$ 6.00$ per doz.

Canariensis-Flesh white, with rich eanary cen ter. $35 c ; \$ 3.50$ per doz.

Christophe Achord-Pale rose to ehamois to lilae center.

Couronne d'Or-Very late. Good sized flowers of creamy white, sometimes flaked carmine at center. $50 \mathrm{c} ; \$ 5.00$ per doz.

Delache-Tall; immense globular heads of crim. son-maroon.

Dorchester (Richardson) - Pink. One of the latest to bloom. Decidedly dwarf, compact grower; flower very full and double, in color about the shade of La France Rose. 50e; $\$ 4.50$ per doz.

Duchess de Nemours-Large and full; the most nearly pure white. $75 \mathrm{c}$.

Duchess de Orleans-Large, rose shaped flowers with spreading guards of rosy lake; incurving center of salmon, mottled rose.

Duke of Wellington-Large, creamy white.

Edulis Superba-Very large, round and fluffy flower, bright rose-pink. The silvery reflex and crinkled petals cause a charming mottled appearance. One of the earliest and best. $35 \mathrm{c} ; \$ 3.50$ per doz.

Edouard Andre-A magnificent dark bedding Peony. Very large globular flowers of highly varnished mahogany-red, ultimately opening out to Anemone shape and revealing a gorgeous collar of gold. $50 \mathrm{c} ; \$ 5.00$ per doz.

Felix Crousse-Late. Large, round heads perfectly double; deep crimson, marked with eardinal at base of petals. $\$ 1.00 ; \$ 10.00$ per doz.

\section{PEONIES}

Betwren the magnificent Rhododendron and the lovely June Rose, comes the Peony. It is used in the same way and in conjunction with its two stately rivals, to continue a bold color display from May to July. While in close harmony with the others, the Peony is more lavish in its bloon and makes the most pretentious show; besides which, it is luardier than either and more easily cultivated. Modern culture las developed many superb varieties, witl flowers beautifully moulded and expressing the most delicate tints as well as the most intense colors. Their cut blooms are very lasting, and in most cases are exquisitely scented. Plant in deep, rich, well-prepared soil, cover ing the buds but an inch or two. Do not expect too much of them the first year, as they are a little slow in establishing themselves.

Agida-Violet-red, semi-double.

Alba Sulphurea - Liglit sulphur-yellow, changing to white as flower becomes older. 35e; $\$ 3.50$ per doz. Anemoneflora-Large; pale rose with buff center. Anemoneflora Rubra-Very broad wide open flowers, bright crimson with thick center of yellow stamens.

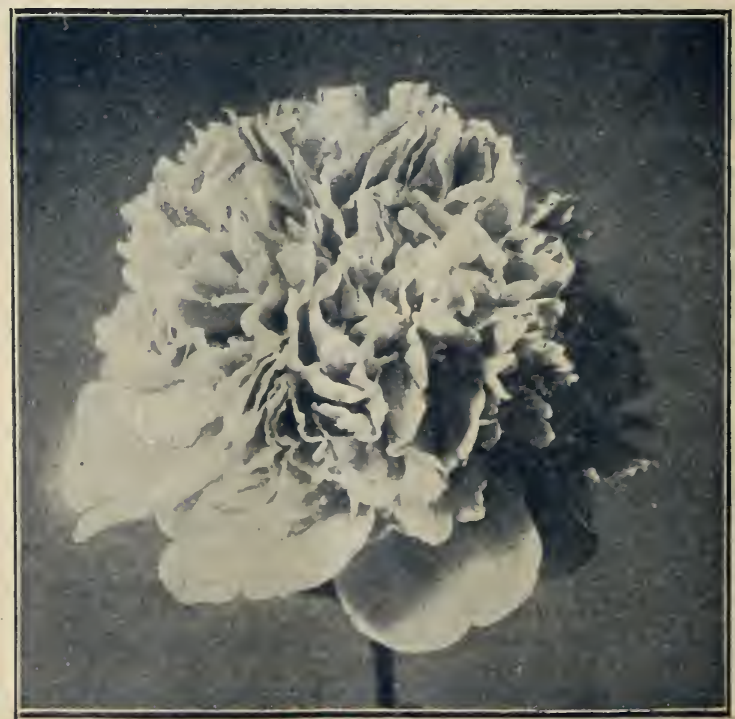

EDULIS SUPERBA. 


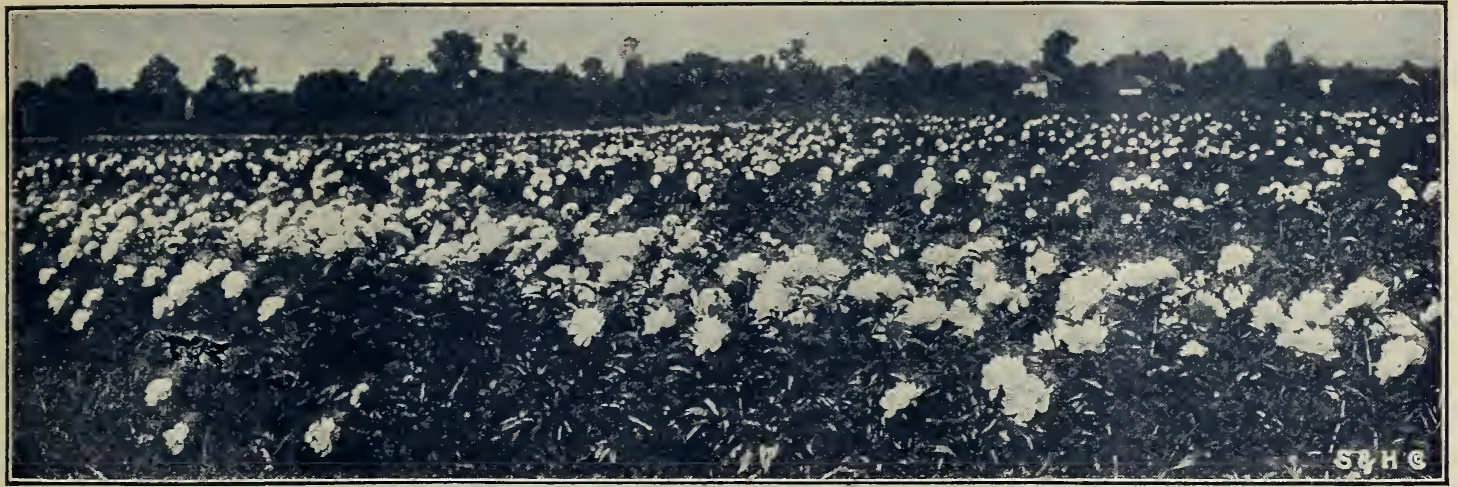

PEONY FESTIVA MAXIMA AT PAINESVILLE NURSERIES.

Festiva Alba-One of the best ordinary whites.

Festiva Maxima-About the largest and undoubtedly the most popular Peony of them all. High built flowers borne on long, stiff stems; the purest white, inner petals slightly tipped carmine. Early. 35c. each; $\$ 3.50$ per dozen.

Francois Ortegat-Tall growing, with long stems; flowers of good size and shape; deep claret maroon.

Henri Demay-Late; very large, full and fragrant. Violet purple.

Hercules-A magnificent bedder-foliage concealed by bloom. Loose globular heads open out to Anemone shape, 8 inches across. Variegated; from bright rose to blush white, with thick collar and center of deepest yellow. $35 \mathrm{c} ; \$ 3.50$ per dozen.

Humei-Pure, bright, deep rose; vigorous grower, one of the best late blooming varieties.

Isabelle Karlitzky-Delicate rose, very large, and full.

Jeanne d'Arc-A ehoice variety notable for its exquisite perfume and other good eutting qualities. Guards pale lilac-pink, with full tufted center of sulphur. $50 \mathrm{c} ; \$ 5.00$ per dozen.

Jules Calot_Bright pink fading to flesk.

Lady Leonora Bramwell-Silvery rose

L'Eclatant_Broad full flower, purplish-crimson; the best of its color.

L'Esperance-Deep rose with crinkly, white tips; extra large and fine; the earliest large pink.

Louis Van Houtte-Brilliant, velvety cerise-red.

Mad. Breon-Flowers, outside flesh, center lemon; occasionally carmine tipped, when first open; entire flower gradually changing to pure white.

Mad. Calot-Large, convex flowers, blush white with salmon shadings.

Mad. Lebon-Valuable late red. Flowers ball-shape, very rich cherry-rose. $50 \mathrm{c} ; \$ 5.00$ per dozen.

Magnifica-Magnificent rounded flowers of flesh white rising to cream: 35e; $\$ 3.50$ per dozen.

Marie Lemoine (Calot)-Dwarf, extra late, and very scarce. White, faintly tinged chamois. $\$ 1.00$ $\$ 10.00$ per dozen.

Mary Stuart-Blush, bleaching to pure white. $50 \mathrm{c}$; $\$ 5.00$ per dozen.

Meissonier-Deep velvety cardinal, violet tipped. Flowers large and high built, with twisted and imbricated petals. $75 \mathrm{c} ; \$ 7.00$ per dozen.

Modeste Guerin-Brilliant carmine-rose, with a high and stiff center full of rosy-pink petals. $35 \mathrm{c} ; \$ 3.50$ per dozen.

Mons. Jules Elie-The peerless pure pink. Broad reflexing guards with a high pyramidal body of semi-quilled petals converging to an apex. One of the largest, handsomest and most lasting cutting sorts in existence. $\$ 1.00$.
M. Thiers-Bright magenta, with full feathered center. Mont Blanc-A magnificent white, of large size, even compact shape, and delightful fragrance. Guards paper-white; body irory white, tinted cream at base of petals. Profuse and lasting bloom. 50c; $\$ 5.00$ per dozen.

Officinalis Rubra fl. pl.-Rich deep crimson; the great Decoration Day Peony.

Officinalis Rosea-Earliest pink. $35 \mathrm{c} ; \$ 3.50$ per dozen.

Prince de Galles-Cup-shaped; purplish crimson.

Princess Mathilde-Broad, full flower; delicate rose, flushed salmon.

Pulcherrima-Remarkably free bloom, habitually in close clusters. Guards blush, the creamy interior merging into a purple flaked center of rose. $35 \mathrm{c}$; $\$ 3.50$ per dozen.

Queen Victoria-The broad guard petals are a pretty blush-white; center slightly edged pink. Large.

Rosea Plenissima Superba-A superior double red sort, full centered and massive; bright crimson.

Rubra Superba-Very tall and strong, with long, stiff stems and elegant dark red flowers. 50c; $\$ 5.00$ per dozen.

Rubra Triumphans-Early. A satiny-finished, intensely rich crimson; sweetly fragrant.

Tenuifolia fl. pl.-Highly ornamental, feathery foliage entirelv distinct from any other sort, with handsome flowers of brilliant ${ }_{*}$ crimson. $35 \mathrm{c} ; \$ 3.50$ per dozen.

Triumphe de Grande-A low, bushy bedding sort, literally covered with broad clusters; the prevailing white prettily variegated with sulphur, pink and carmine. 35c; $\$ 3.50$ per dozen.

Triomphe de Paris-Outside white, center sulphuryellow.

Unless noted, 25c each; $\$ 2.50$ per dozen; $\$ 18.00$ per 100 .

\section{TREE PEONY}

Peony Moutan-A handsome flowering shrub, ultimately attaining a height of 4 to 5 feet. Flowers are very large and showy, displaying many striking shades of color. 50c each; $\$ 5.00$ per dozen.

\section{HARDY GARDEN PINKS}

Gertrude-White, variegated with maroon.

Her Majesty-Very large and purest white.

Homer-Rich rosy red with dark center.

Laura Wilmer-White, with purplish maroon center.

Mary Gray-Reddish purple, narrow white lacing.

White Reserve-Pure white, fringed.

Field grown plants $15 \mathrm{c}$ each; $\$ 1.50$ per dozen. 


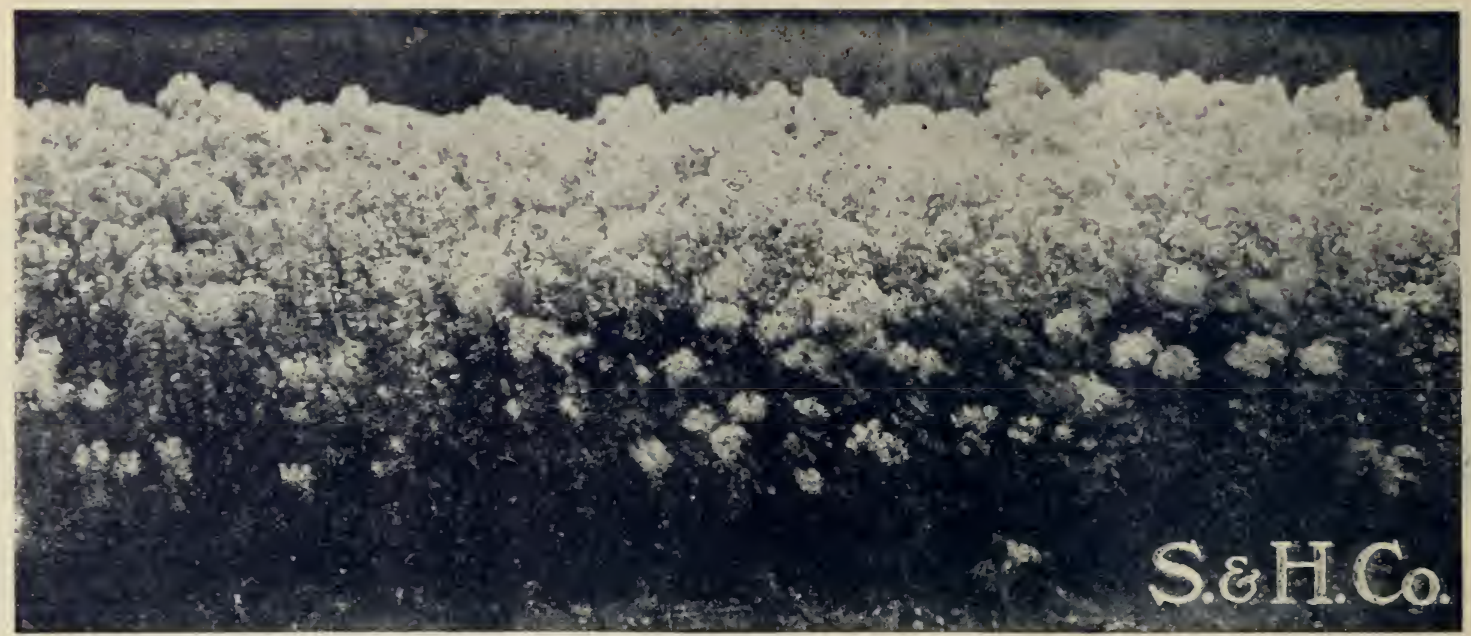

\section{HARDY PHLOX}

No class of hardy plants is more desirable than the Ierennial Phloxes. They will thrive in any position and can be used to advantage in the hardy border, in large groups on the lawn, or planted in front of belts of slirubbery, where, by judicious pinching back and removing faded flowers, a constant succession of bloom may be had until frost. Except the dwarf species, all Hardy Phloxes are admirably adapted to cutting. We offer a select list of strong field grown roots.

Cinnabar. A magnificent new red Phlox exhibiting the largest, most gracefully sym any variety ever offered. It blooms early and long with great freedom. Bright cherry-red toned lightly with salmon, and further softened by the deep crimson eve. 1-year field-grown plants, $75 \mathrm{c}$ each; $\$ 8.00$ per dozen.

\section{GENERAL COLLECTION}

(Strong field grown roots.)

Athis-Tall; dark stemmed. Light salmon, violet eye. B. Comte-Red or French purple. 20c.

Caran d'Ache-Geranium red, with old rose shadings and white eye.

Coquelicot-A glowing orange red with violet eye. $25 \mathrm{c}$. Eclaireur-Purple-crimson, light aureole.

Eiffel Tower-A strong growing, large trussed sort; flesh pink with red eye. 25e.

Etna-Large flowers, orange searlet with maroon eye.

Eugene Scott - Large flowers; white heavily suffused lilac, falling to porcelain blue; rarmine eye.

Eugene Danzenvillier-Iilac with white edges.

Fraulein G. Von Lassburg-Extremely large florets and fine trusses. P'nre white. A choice variety. 20c; $\$ 1.75$ per dozen.

Gen. von Heutsze-Salmon red tinged with rose; lighter at center.

Hofgartner Starke-Purple, with a dark red center.

Josephine Gerbeau-Fine large trusses of white, with a central blot(h of pale carmine.

Le Mahdi-Deep reddish violet. Farly. 20e.

Lumineaux-Bright rose pink.

Miss Iingard-Longest splies of any Phlox-blooms from the ground up. Waxy white, lavender eye.

Mme. P. Langier-A dazzling pure erimson; one of the choicest dark reds
Mr. Gladstone-Large flat flower, terder rose, witl light red eye.

Pantheon-I he peerless pink. Extra large, always flat flowers of salmon rose.

Pluton-Dwarf, late purple.

Princess Louise-Medium sized white flower, with a little rose eye. Very symmetrical and dainty.

Prof. Schlieman-Ornamental red-stemmed foliage; very brilliant with shapely panicles of rose-lilac flowers. Late.

Richard Wallace-Violet-eyed, white.

Snowflake-Good flower of snowy white.

The Pearl-A standard, pure white.

Virgo Marie-Unblemished white, rooty and vigorons.

Unless noted, $15 \mathrm{c}$ each; $\$ 1.50$ per dozen; by express, 10c each; $\$ 1.00$ per dozen.

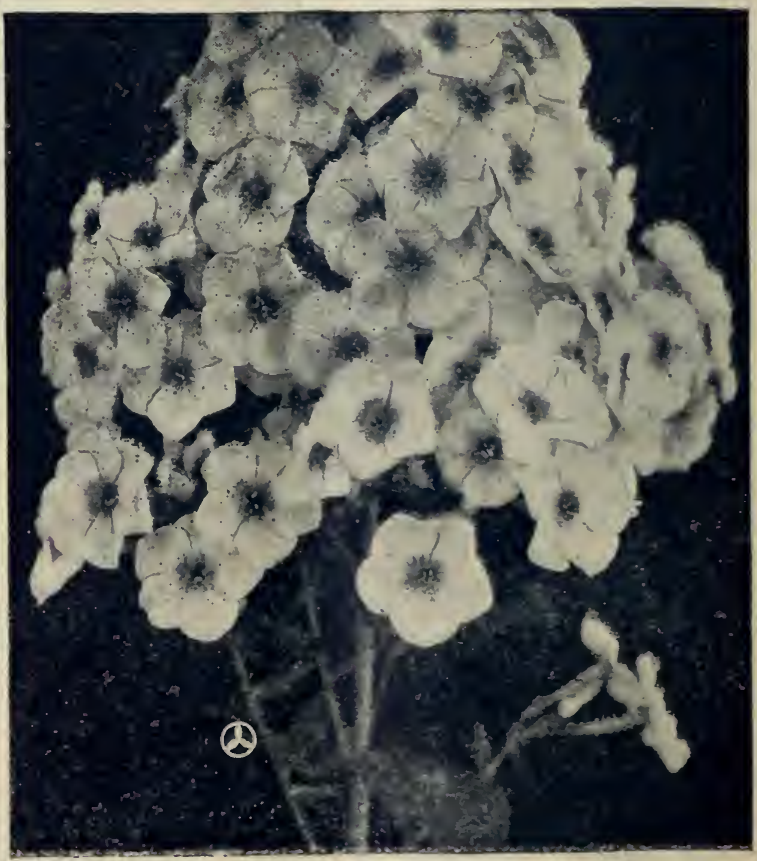

PHLOX JOSEPHINE GERBEAU. 


\section{General List of New and Old Hardy Perennial Plants}

\section{PRICE}

Unless noted, all items under this heading at the uniform price of 15 cts. each; $\$ 1.50$ per dozen.

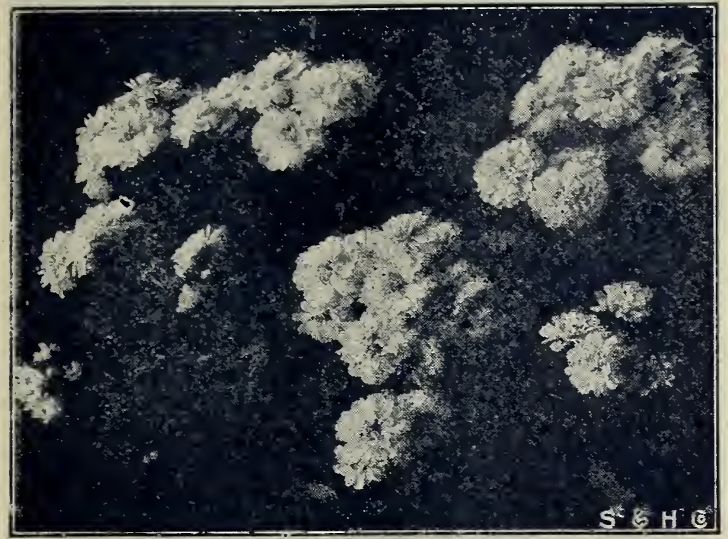

ACHILLEA, THE PEARL.

Achillea, The Pearl-One of the very best white flow ered border plants, resembling Pompon Chrysanthe mums.

- Millefolium Roseum-Finely cut foliage, flat flower heads, color magenta.

ÆEgopodium Variegatum (Gout Weed)-A rapid growing plant one foot high, with prettily variegated green and yellow foliage; valuable for edging.

Æthionema Persicum - Dense spikes of deep rosecolored flowers. Blooms all summer. 10 to 12 inches.

Agrostemma Coronaria-Flowers bright erimson, phloxshaped; with velvety silver foliage. $10 \mathrm{c} ; \$ 1.00$ per doz.

- Coronaria Alba-Pure white flowers. 10c; $\$ 1.00$ per doz.

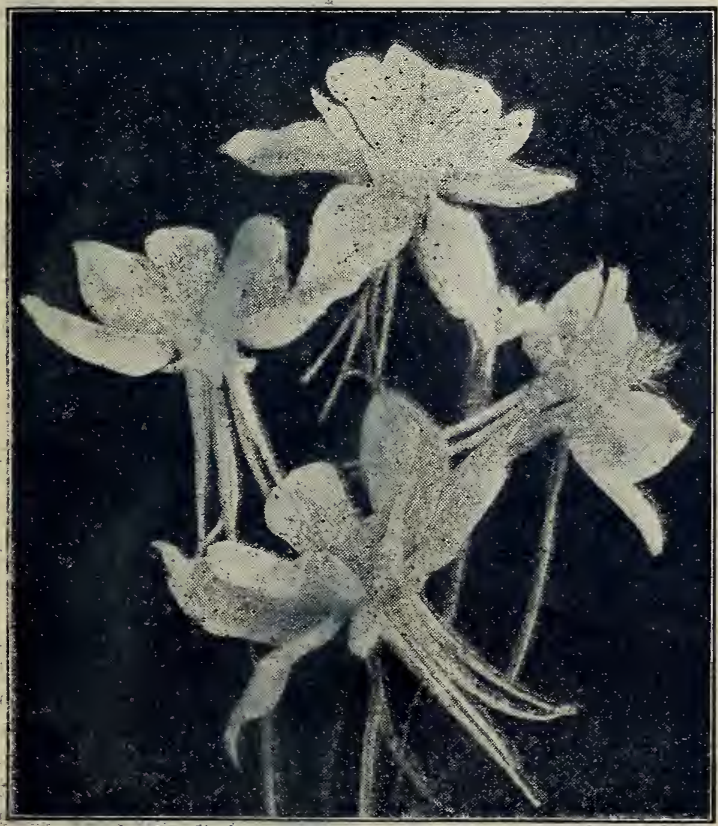

AQUILEGIA-Spring Columbine.

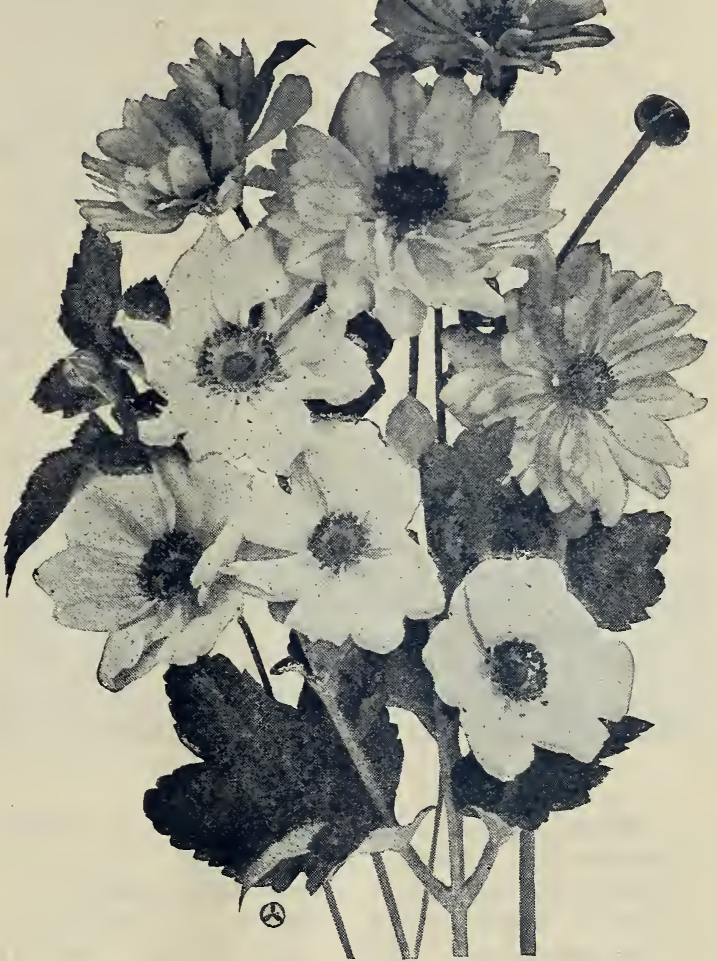

FALL BLOOMING "WIND FLOWERS."

Anemone Japonica-(Wind Flowers) - A most valuable class of hardy plants suitable for edging, massing or single specumens. They grow rapidly 2 to 3 feet and are profuse in bloom, gaining strength and beauty each year. The blooming period extends from August till mid-November, the large open Howers furnishing abundant cut-flowers and a brilliant field display.

Anemone Japonica Alba-Purest white, with yellow center. $10 \mathrm{c} ; \$ 1.00$ per doz.

- Queen Charlotte-Flowers semi-double, broad and perfectly formed, of that pleasing shade of pink found in La France Rose. 10e; $\$ 1.00$ per doz.

- Rosea Superba-Very free; delicate silvery rose. $15 \mathrm{c} ; \$ 1.50$ per doz.

- Rubra-Showy rose-color, yellow center. 10c; $\$ 1.00$ per doz.

- Whirlwind-Excellent double white flowers, $21 \%$ to 3 inches across. 10e; $\$ 1.00$ per doz.

Anthemis Tinctoria (Golden Margtierite)-Daisy-like flowers, clear yellow. 2 feet. $10 \mathrm{c} ; \$ 1.00$ per doz.

- - Pallida-Plant, completely hooded with ereamy white flowers. $10 \mathrm{c} ; \$ 1.00$ per doz.

Aquilegia (Columbine)-The distinct, clear-cut foliage and delicate arrangement of colors in the flowers of Columbine make it one of the showiest and most desirable of the hardy garden plants; especially suitable for rockwork, at the base of foundation walls and under trees.

- Chrysantha-The "Golden Spur', Columbine.

- Caerulea-The dainty "Rocky Mountain Columbine," blue and white.

- - Hybridum-Very large flowered Hybrids in varied shades of the mother colors.

- Truncata-Scarlet, with yellow tips. 
Anchusa Italica, Dropmore Variety - A vastly improved form of the Italian Alkanet, with 3 to 4 feet of coarse, leafy growth and a continuous show of deep blue clusters all summer. 25c; $\$ 2.50$ pel: doz.

Arabis (Rock ('ress)-The Arabis are low growing plants especially suited to rockwork, flowering in small terminal racemes. They commence to bloom in May and continue a long time.

- Albida-White.

- Alpina - White flowers, ${ }^{*}$ sualler than Albida.

- Grandiflora Superba-Largest flowers.

Armeria Maritima Splendens (Sea Thrift)-Dwarf compact growing plants, foliage evergreen; throwing up numberless spikes of rosy pink flowers fro:u spring till fall. (Old clumps resemble a round, relvety cushion.

- Formosa Alba-Slightly larger flowers, of creamy white.

Asclepias Tuberosa (Butterfly Flower)-Flowers brilliant orange red, on stems 2 feet high, each producing several heads. $10 \mathrm{c} ; \$ 1.00$ per do\%.

Asters (Michaelmas Daisies)-Bloom in great profusion, throughout the autumn.

- Laevis-A splendid light blue variety.

- Mme. Soyneuse-Pale lilac, free; dwarf.

- Novae Angliae-Its deep bluish purple flowers make a charming show after many fall plants have succumbed to the cold.

- Rosea-A companion to abore, in rosy crimson.

- Snowflake-18 inches; pure white.

- Tartarica-Tall, broad leaved; bright purple.

- Thos. S. Ware-Delicate blue, 3 to 4 feet.

- Trinervus-Deep violet-purple; in bloom during Oct. and Nov. $2 \frac{1}{2}$ feet.

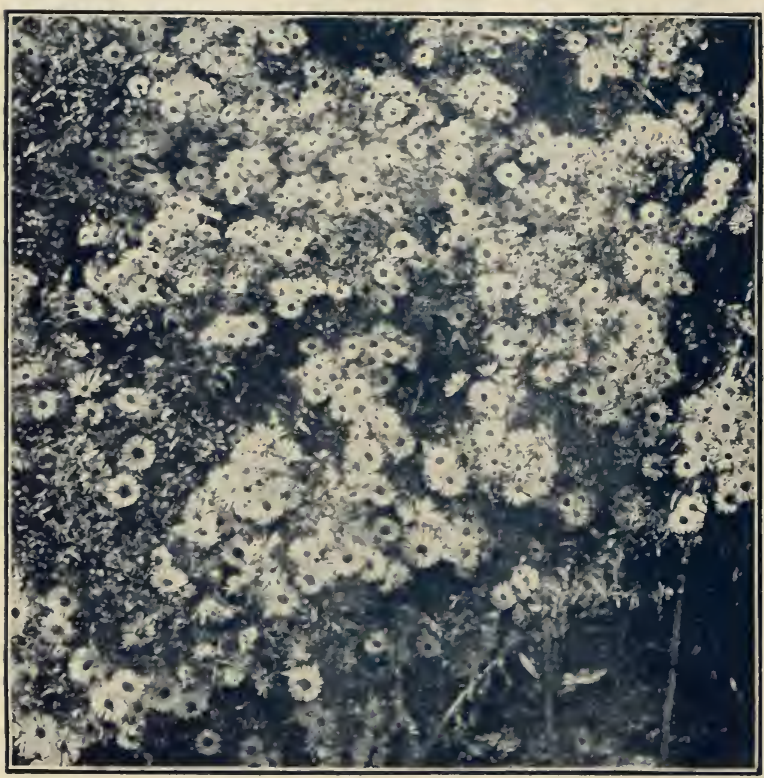

ASTERS- "Michaelmas Daisies."

Baptisia Australis (False Indigo)-Deep blue flowers in pretty racemes during June and July. 2 feet. $10 \mathrm{c}$.

Bocconia Cordata (Plume Poppy) - Six feet. Immense, flat, deeply indented leaves of silvery green on paler stalks. Flowers creamy white, produced in large panicles.

Boltonia Asteroides (False Chamomile)-Bushy plants 5 feet high, with Aster-like white flowers. 10c; $\$ 1.00$ per doz.
Callirhoe Involucrata (Polpy Mallow) - A handsome trailing plant with deeply cleft foliage and large saucer-shaped flowers of reddish purple. All summer.

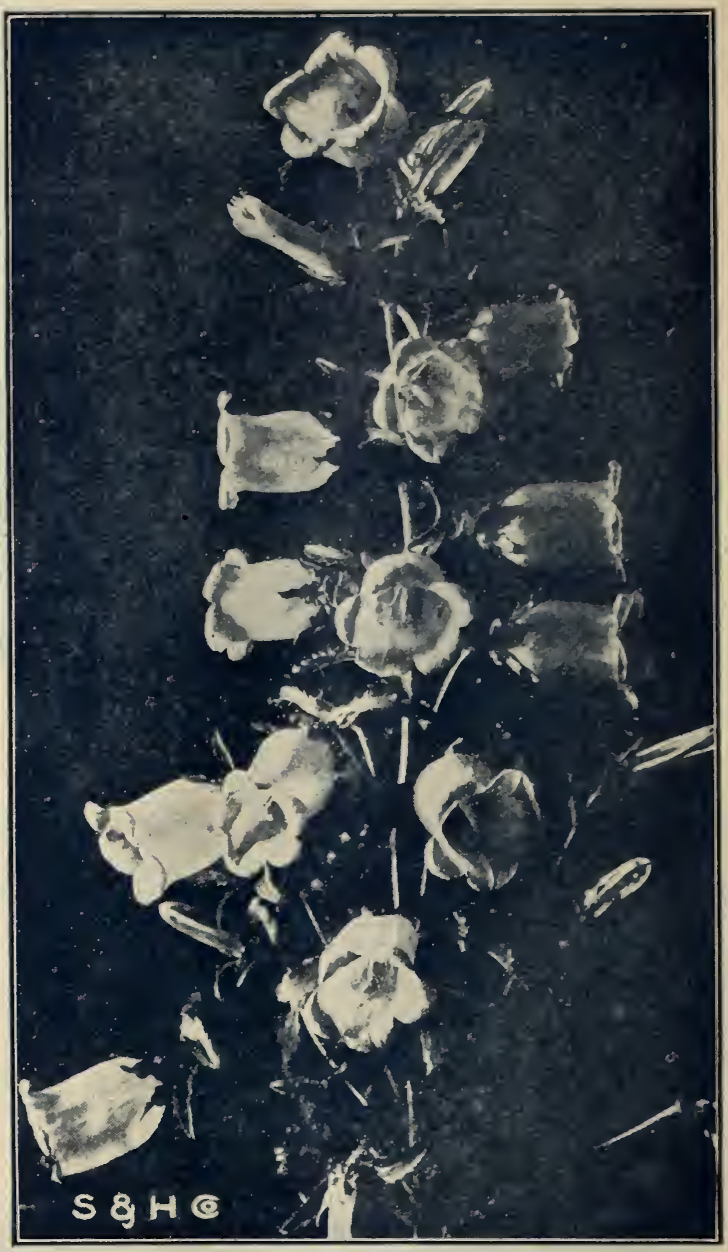

"CANTERBURY BELLS."

Campanula Media - The well known "Canterbury Bells.', Blooms in July, height 2 to 3 feet. Blue, Rose or White.

- Carpatica (Carpathian Hare-Bell) - A pretty compact species, not exceeding eight inches high, flowers clear blue, one inch in diameter.

- Carpatica Alba-White flowering.

- Persicifolia (Peach Bells) - 11/2 to 2 feet high, blue, salver-shaped flowers.

- - Alba-White flowered.

- Pyramidalis (Chimney Bell-flower)-Very conspieuous; 4 to 5 feet high. Salver shaped blue flowers borne profusely in September.

- - Alba-Corresponding white flower.

Cassia Marilandica (American Senna)-Blooms in large panicles of bright yellow, July to August. 3 to 4 feet.

Catananche Caerula (Cupid's Dart)-A pretty sum. mer-blooming perennial, bearing numerous peduncled flowers of light blue. Useful for cutting and often used as an everlasting flower. $10 \mathrm{c} ; \$ 1.00$ per doz.

Clematis Davidiana-A choice shrubby species attaining a height of 2 to 3 feet, in bloom during August and September. Flowers are tubular shaped; of a delicate lavender-blue, and very sweet scented. 
Clematis Tubulosa - A fine erect sort with bright green leaves and numerous corymbs of light blue, tubular flowers.

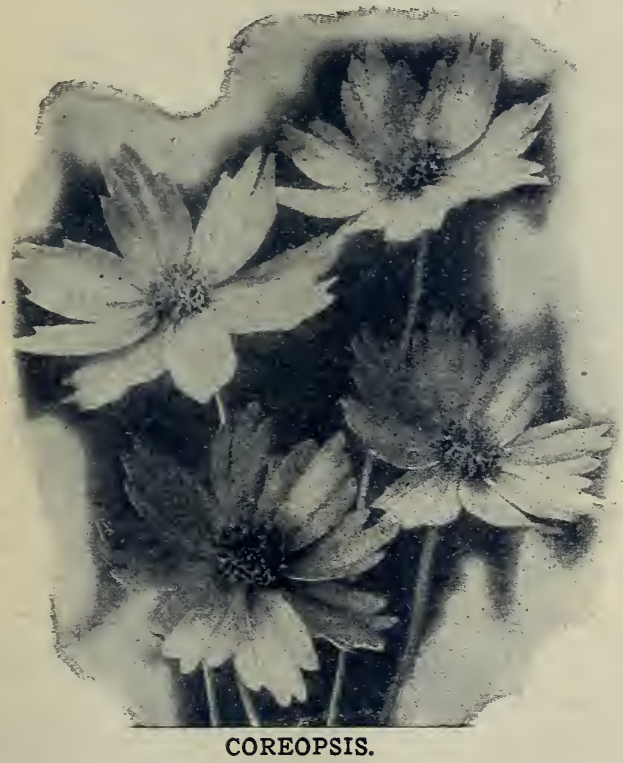

Coreopsis Lanceolata Grandiflora-The perfected strain of a long popular hardy plant. Flowers are rich golden yellow, borne in great profusion nearly the entire summer. $10 \mathrm{c} ; \$ 1.00$ per dozen.

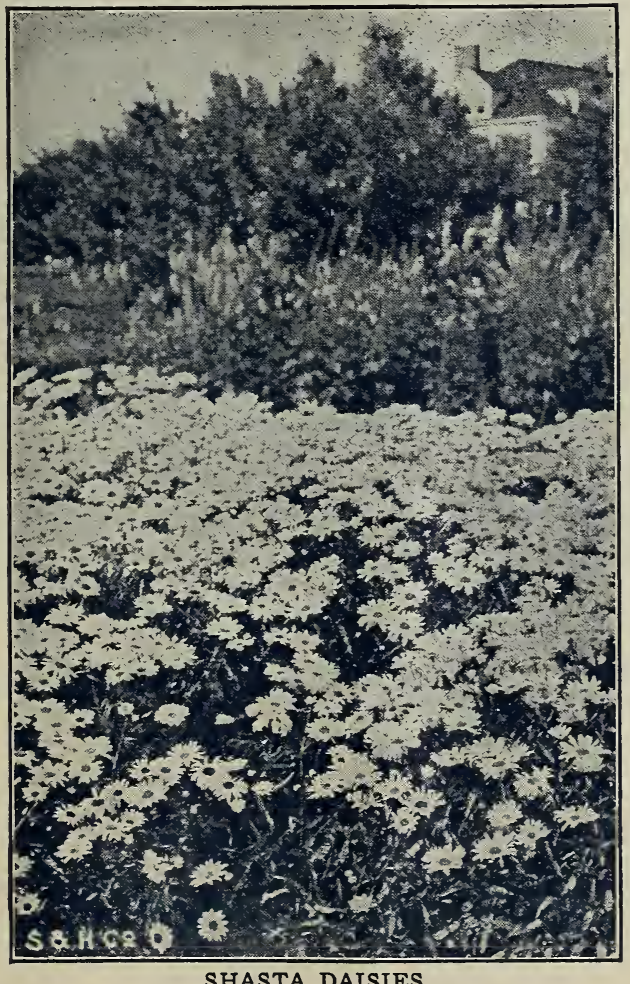

SHASTA DAISIES.

Shasta Daisy-A mixture of Burbank's new sorts,Alaska, California and Westralia.

Ranging in shape from fully double, to single; and in color, from pure white to pale lemon yellow; extremely productive. $10 \mathrm{c} ; \$ 1.00$ per dozen.

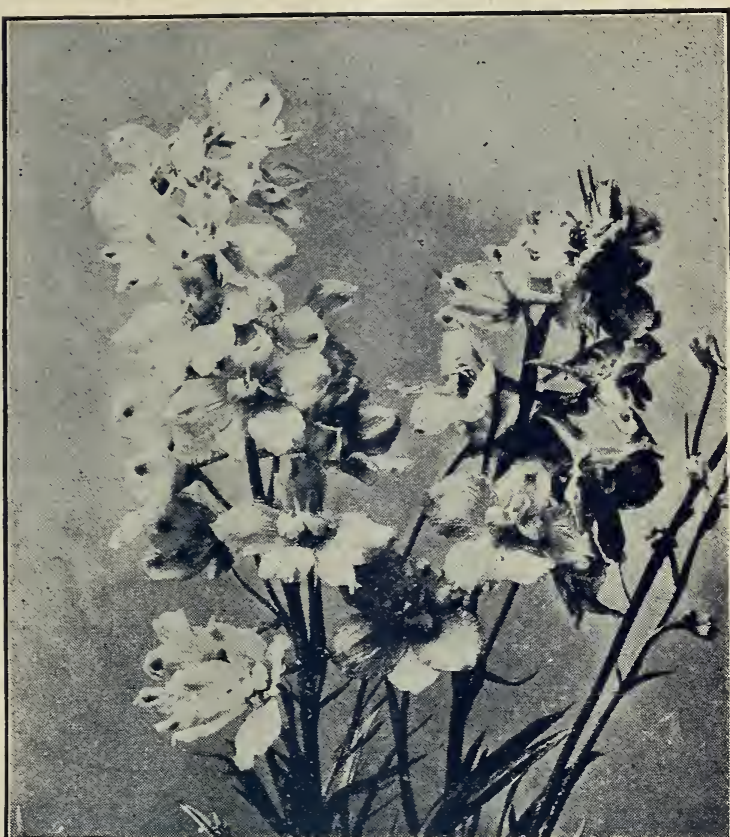

HYBRID LARKSPUR.

Delphinium (Perennial Larkspur)-Indispensable to the herbaceous garden. Their long, showy spikes of flowers pers. st from June till frost and furnish the most satisfactory blues to any color scheme.

- Belladonna-A magnificent new sort, unrivalled for continuance of bloom, with large spikes of the most delicate turquois-blue. July till frosts. 25c; $\$ 2.50$ per dozen.

-Chinensis-Fine stems and deeply cleft foliage; flowers showing all lighter shades of blue, $18 \mathrm{in}$. $10 \mathrm{c} ; \$ 1.00$ per dozen.

- Alba-Pure white flowers. 10c; $\$ 1.00$ per dozen. - Formosum-The old fashioned very dark blue variety. Three to four feet. $10 \mathrm{c} ; \$ 1.00$ per dozen.

- Coelestinum-Delicate blue $10 \mathrm{c} ; \$ 1.00$ per dozen.

- Hybridum-A choice strain of Hybrids embracing all shades of blue and purple. $10 \mathrm{c} ; \$ 1.00$ per dozen.

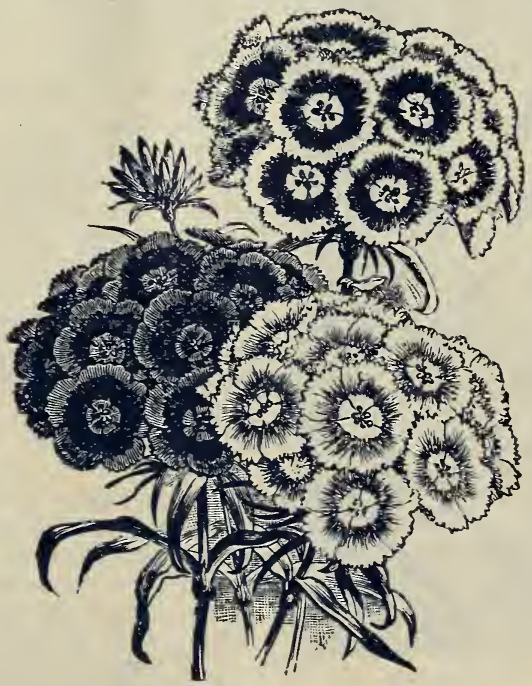

Dianthus Barbatus Mixed-The ever popular "Sweet William,' representing a great variety of colors and combinations. $10 \mathrm{c} ; \$ 1.00$ per dozen. 


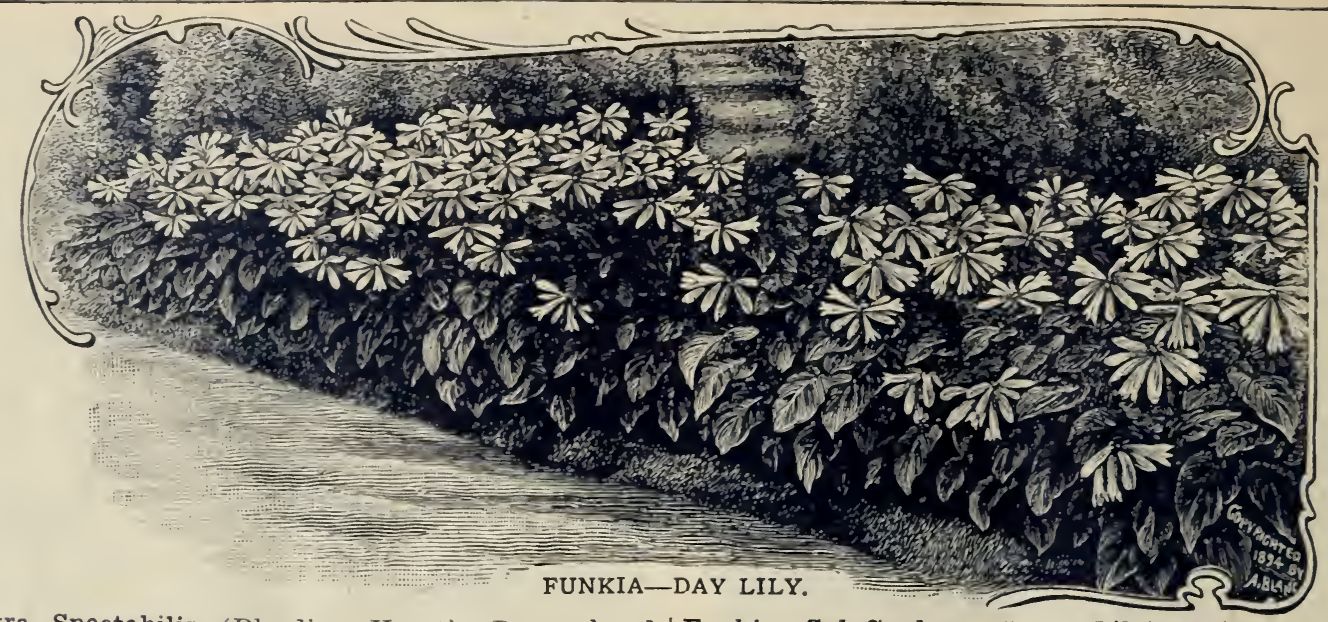

Dicentra spectabilis (Bleeding Heart)-Rose-colored, Funkia Sub-Cordata (Day Lily)-Wide circles of heart-shaped flowers in drooping racemes; early broad leaves. Flowers large, waxy white, borne in
spring. 2 feet.

Dictamnus Rubra (Gas Plant) - Fragrant foliage; spikes of curious red flowers. $10 \mathrm{c} ; 12$ for $\$ 1.00$.

- Alba_White flowered. 20c; $\$ 2.00$ per dozen.

Digitalis (Fox Glove)-An old fashioned plant that furnishes a grand display of thimble-shaped flowers in inmense spikes during July and August.

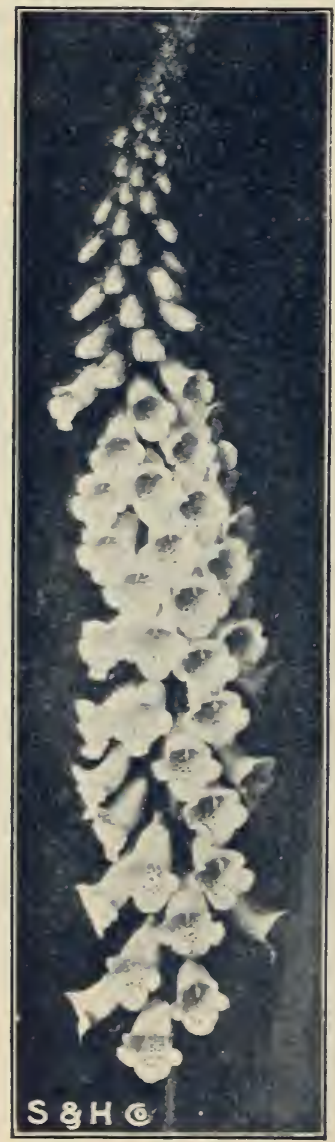

FOXGLOVE

- Gloxiniaeflora A 1 b a White. Fine for cutting. $10 \mathrm{c} ; \$ 1.00$ per dozen.

- Gloxiniaeflora Rosea Rose colored; bright and showy. $10 \mathrm{c} ; \$ 1.00$ per dozen.

Echinops Sphaerocephalus (Globe Thistle)-Grows 5 to 7 feet, with coarse prickly foliage and stems of silvery green. The pale blue, thistle-like flowers are very attractive and quite numerous. Planted in masses behind Eryngiums, or in front of B oc con i , Helianthus, etc., it is very striking.

Eryngium Amethystinum (Sea Holly) - A highly ornamental plant growing 2 to 3 feet high, with hard, angular stalks; fine cut, spiny foliage, and large thistle-like terminal flowers-all a glistening amethystine blue.

Eupatorium Ageratoides (IV h i t e Snakeroot) Dense terminal heads of minute white flowers. 3 feet.

- Purpureum (Joe Pye Weed)-When rig h t ly used in shrubbery borders, this variety is very effective. Grows 7 feet tall, with whorled leaves and large loose heads of rosy-purple flowers.

Funkia Undulata Variegata-Graceful, narrow leaves having a fluted white edge, and pale lilac flowers.

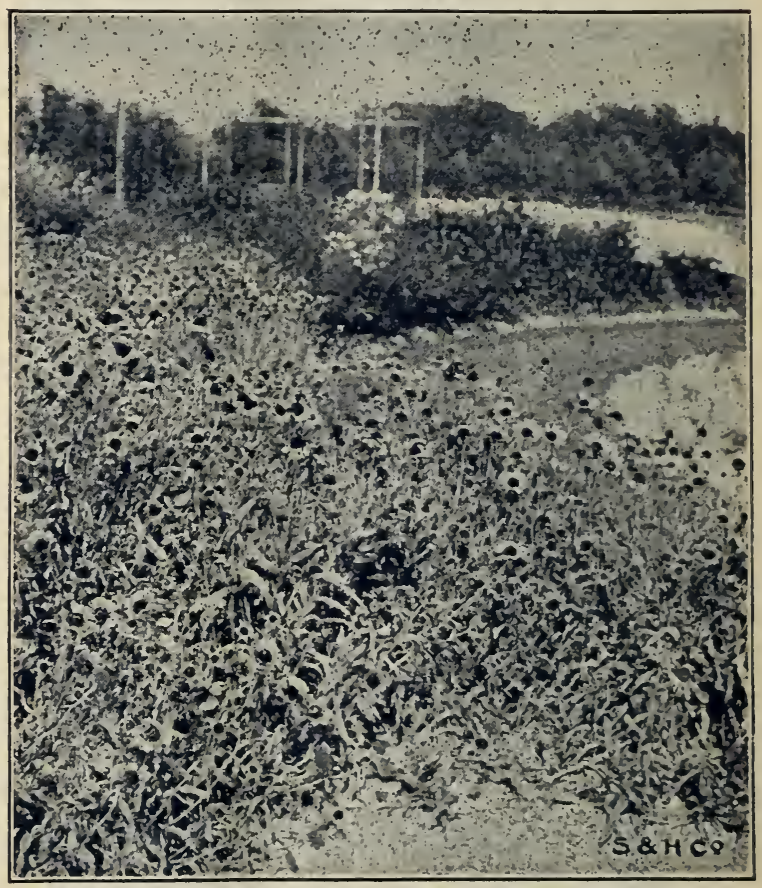

GAILLARDIA-"BLANKET FLOWER."

Gaillardia Grandiflora (Blanket Flower)-Makes one of the most gorgeous and prodigal displays of all perennials. Flowers often measure 3 inches in diameter, on clean 2 feet stems. A hard center of deep maroon is thickly bordered by petals of orange and yellow, strikingly ringed by circles of crimson, red and maroon. Poor soil will do, and a constant show is assured from .June till frost. $10 \mathrm{c} ; \$ 1.00$ per dozen.

Gypsophila P.ıniculata (Baby's Breath)-Good for cutting as well as for borders. Flowers are minute but myriad, pure white, produced in immense panicles. $10 \mathrm{c} ; \$ 1.00$. per dozen.

Hardy Ornamental Grasses-In the laying out of lawns and artistic gardens, a few of the many beautiful. hardy grasses should not be overlooked. Their stateliness, tropic luxuriance, and soft color harmoniously punctuate the prevailing green, while their graceful, sinuous yielding to every wind gives animation to gardened landscapes too apt to look "fixed.", 
Hardy Grass-Arundo Donax (Great Reed)-A dark green, broad-leaved reed, attaining sometimes 20 feet in height. 25c; $\$ 2.50$ per dozen.

- Erianthus Ravennae (Hardy Pampas)-Grows from 9 to 12 feet high, frequently throwing up from 30 to 50 flower spikes.

- Eulalia Gracillima Univittata (Japan Rush)-Narrow green leaves with a silvery white midrib, perfectly hardy.

- - Japonica Variegata-Long, narrow leaves, striped with green and white.

- Phalaris Arundinacea Variegata (Ribbon Grass)Green leaves, striped lengthwise with creamy white. $10 \mathrm{c} ; \$ 1.00$ per dozen.

- Uniola Iatifolia (Spike Grass)-Long flat leaves one inch broad; at maturity crowned by gracefully drooping panicles of long, thin spikelets.

Helianthus (Sunflowers)-Very profitable for summer cutting and massy display.

- Maximilliana-Immense single flowers, rich golden yellow, center reddish brown. 5 to 7 feet.

- Mollis Grandifiorus-Light lemon yellow, large single. Foliage quite hairy. 4 feet.

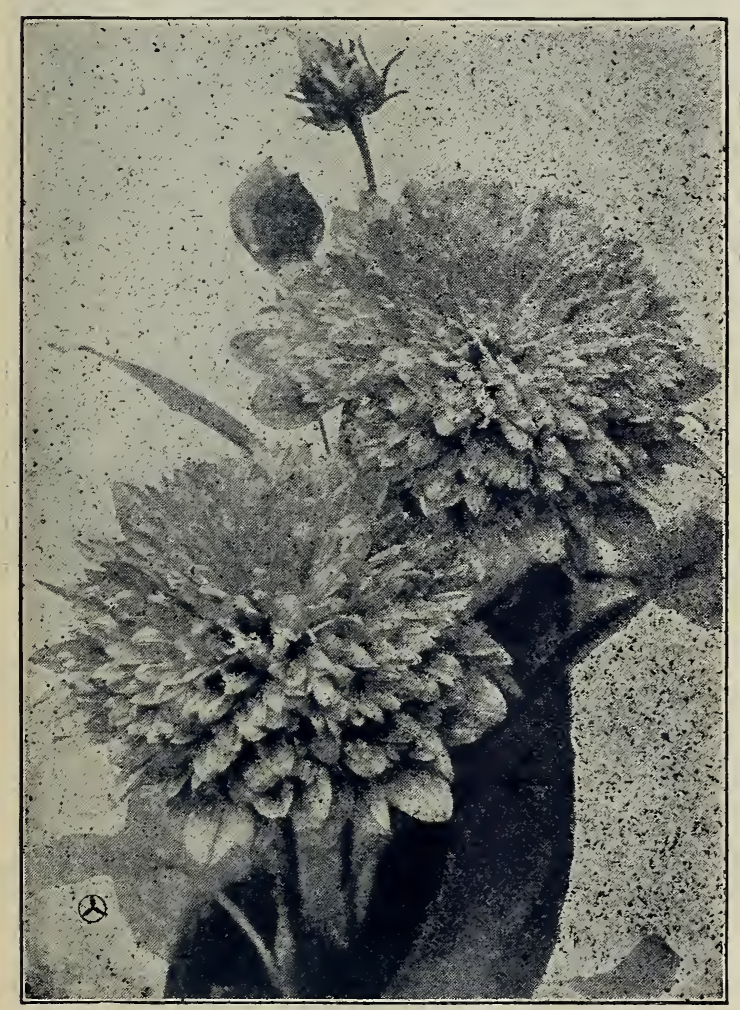

HELIANTHUS MULTIFLORUS PLENUS.

- Multifiorus Plenus-Large double yellow. 4 feet.

- Rigidus-Of fine upright habit of growth. Flowers light yellow with maroon center. 3 feet. $10 \mathrm{c} ; \$ 1.00$ per dozen.

Heliopsis Pitcheriana (Orange Sunflower) - Pretty Daisy-like flowers, orange yellow, with a pyramidal center of darker shade.

Hemerocallis (Day Lilies)-Very effective in clumps and masses. Numerous panicles of orange and yellow Lily-like flowers protruding high above the grass-like foliage.

-Dumortieri-Dwarf and compact; 2 feet; flowers orange. $10 \mathrm{c} ; 12$ for $\$ 1.00$.

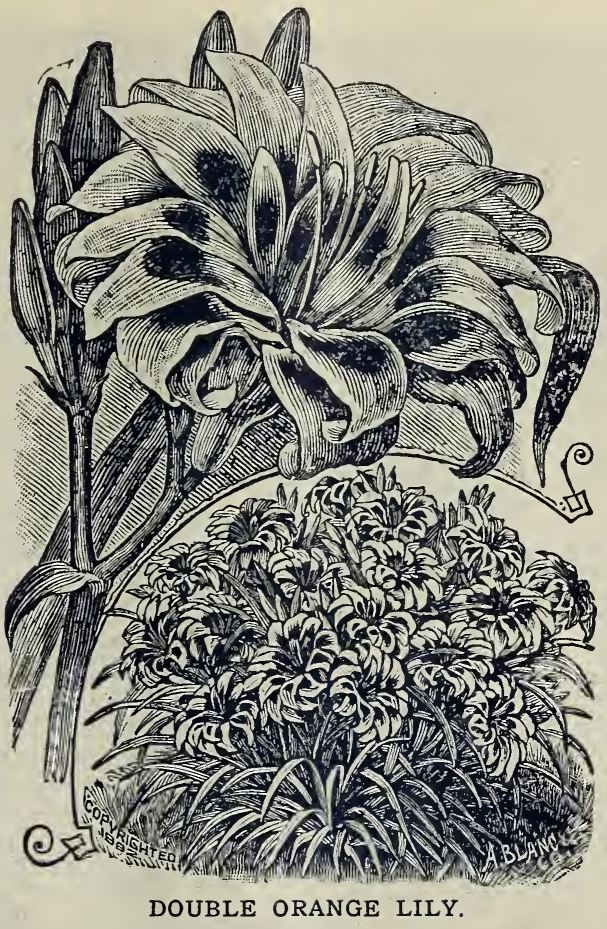

Hemerocallis-Kwamso fl. pl. (Double Orange Lily)Large, double, copper colored flowers.

- Flava (Lemon Lily)-Crowned by beautiful lemoncolored flowers 3 to 4 inches in diameter, and delightfully fragrant. 3 feet. $20 \mathrm{c} ; 12$ for $\$ 1.50$.

Hesperis Matronalis (Rocket)-Stout, bushy plants 3 to 4 feet high, with showy terminal spikes of pink flowers during June and July.

- - Alba_-White flowers.

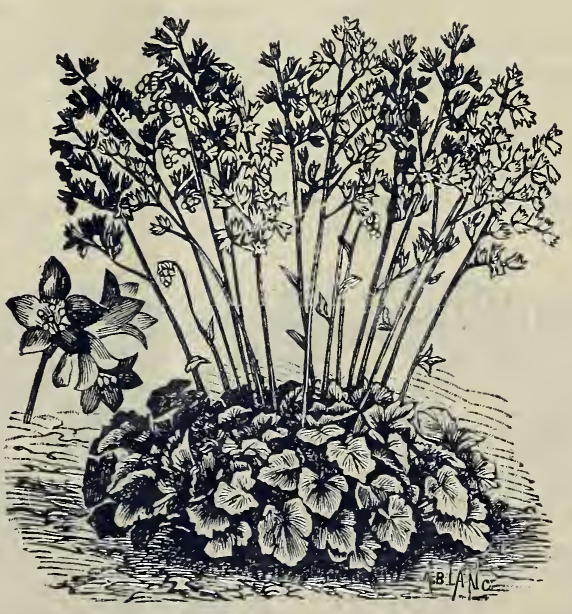

HEUCHERA SANGUINEA.

Heuchera Sanguinea (Alum Root)-A clump of this very desirable plant when in full bloom dazzles the eye with its brilliant crimson spikes. 2 feet.

Hibiscus Moscheutos-The fine old Swamp Rose Mallow. Large purplish pink flowers with large dark eye. Four to five feet. $10 \mathrm{c} ; \$ 1.00$ per dozen.

- Crimson Eye-Immense flowers of purest white, with large centers of velvety crimson. 10c; $\$ 1.00$ per dozen. 


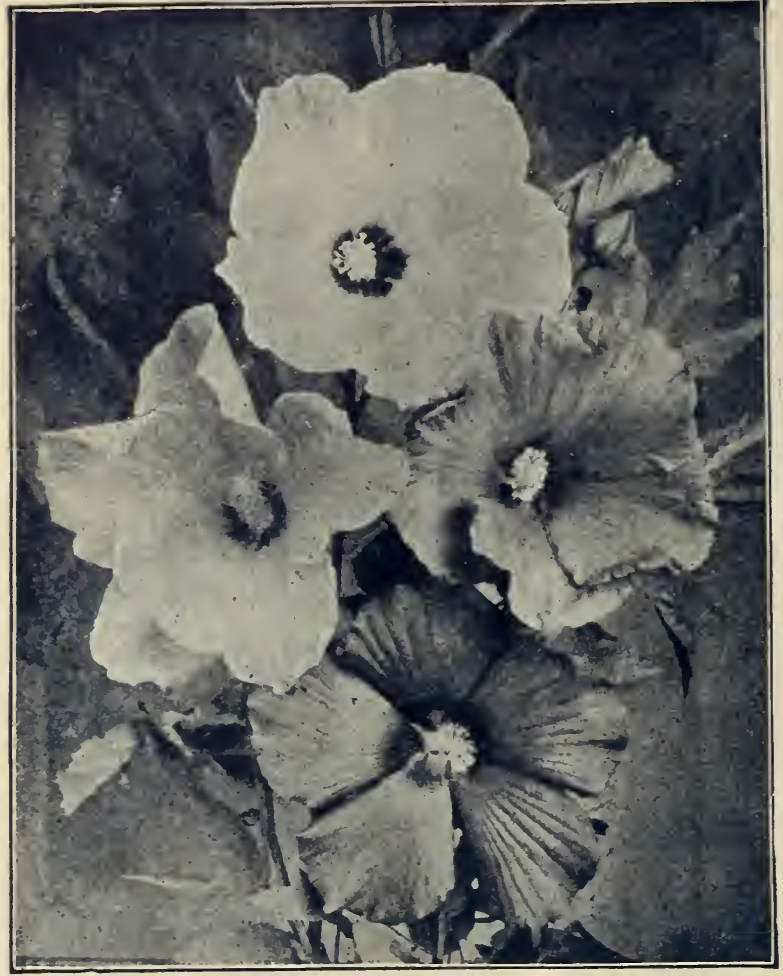

Hibiscus Militaris (Halbert Leaved Rose Mallow)Tall growing; delicate flesh pink, darker toward the center. $10 \mathrm{c} ; \$ 1.00$ per dozen.

Hibiscus “Meehan's Mallow Marvels"-A magnificent new strain of hardy Mallows, which for size and profusion of bloom and richness of coloring are among the most striking and beautiful perennials that grow. Flowers are from 8 to 10 inches in diameter and range in colors from fiery crimson, through various reds and pinks, to purest white. Mixed colors. 50c each; $\$ 4.00$ per dozen.

Hollyhocks-Crimson, Yellow, White, Pink. 10e each; $\$ 1.00$ per dozen.

- Mammoth Fringed-Extra large flowers, in mixed colors. Finely curled and fringed. $15 \mathrm{c} ; 8$ for $\$ 1.00$.

\section{HXXLNTHUS}

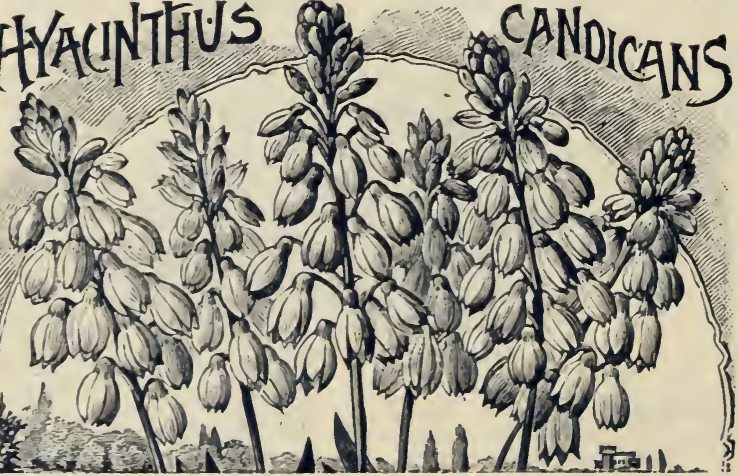

Hyacinthus Candicans - 20 to 30 white, pendant, bellshaped flowers on stalks 3 to 4 feet high. Bloonas early and till late fall. $5 \mathrm{c} ; 12$ for $50 \mathrm{c}$.

Hypericum Moserianum (Gold Flower)-Forms a bush 2 to $21 / 2$ feet high, of slender, well branched stems. Bright golden yellow flowers. $20 \mathrm{c}$.
Iberis Sempervirens-Hardy white Candytuft. 25c.

Iris (See Bulbs, page 10.)

Lathyrus Latifolius (Ilardy Climbing Pea)-Red, pink and white. 20c each.

Liatris Spicata (Blazing Star) -2 to 3 feet spikes of gay furple flowers in September; very conspicuous.

Lilies (See Bulbs, page 11.)

Lobelia Cardinalis (Cardinal Flower)-One of the showiest things in the garden. Intense cardinal-red flowers arranged in stocky spikes 15 to 18 inches long keep the plant aflame throughout August and September. $10 c ; \$ 1.00$ per dozen.

Lychnis Chalcedonica (Maltese Cross)-Heart-loberl stars of brightest vermilion, arranged in large flat panicles. $10 \mathrm{e} ; \$ 1.00$ per dozen.

- Alba-A beautiful white form.

- Alpina-Dwarf growing; rose-colored flowers.

- Sieboldi-Attractive white flowers. 20c.

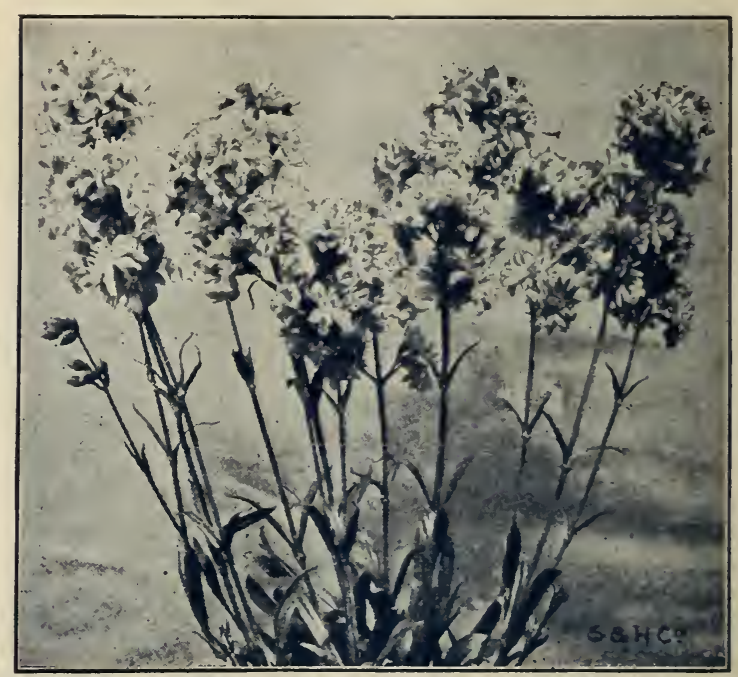

LYCHNIS VISCARIA FL. PL.

- Viscaria fl. pl. (Lamp Flower)-Almost ever-green foliage; in June and July fairly ablaze with close spikes of crimson flowers. The most vivid colored of any hardy perennial.

Lythum Roseum Superbum (Rose Loose strife)-Large compact spikes of rose colored flowers from June to September. 3 to 4 feet.

Monarda Didyma (Bergamot)-A busliy, coarse-leaved plant, growing about 2 feet high; covered with round, full heads of red flowers with a petalage similar to the Cactus Dahlias.

Enothera (Evening Primrose)-Dwarf, bushy plants, showy and valuable in borders.

- Fraserii-Stiffly branching stems crowned with one to two inch pure yellow flowers. 'Two to three feet.

- Missouriensis-A low, spreading plant of trailing habit-good for rockeries. Two to three inch golden-yellow flowers are thickly set among long, curly, silver-edged leaves. $1 \mathrm{ft}$.

- Youngi-Very branchy, with dense glaucous green foliage; flowers lemon-yellow, borne in elusters. Two feet.

Ononis Spinosa (Dove's Thorn)-Small-leaved, dense and thorny, growing about 1 foot high. The bush resembles Thunberg's Barberry, and blooms all summer with numerous small rose-colored terminal flowers. 


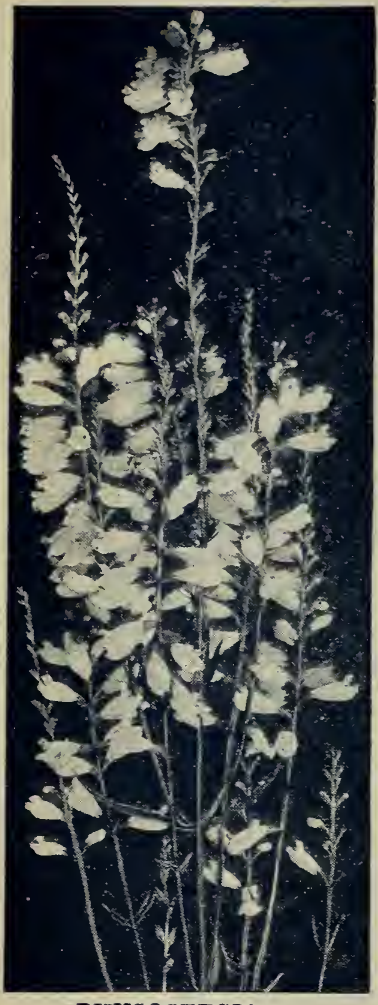

PHYSOSTEGIA

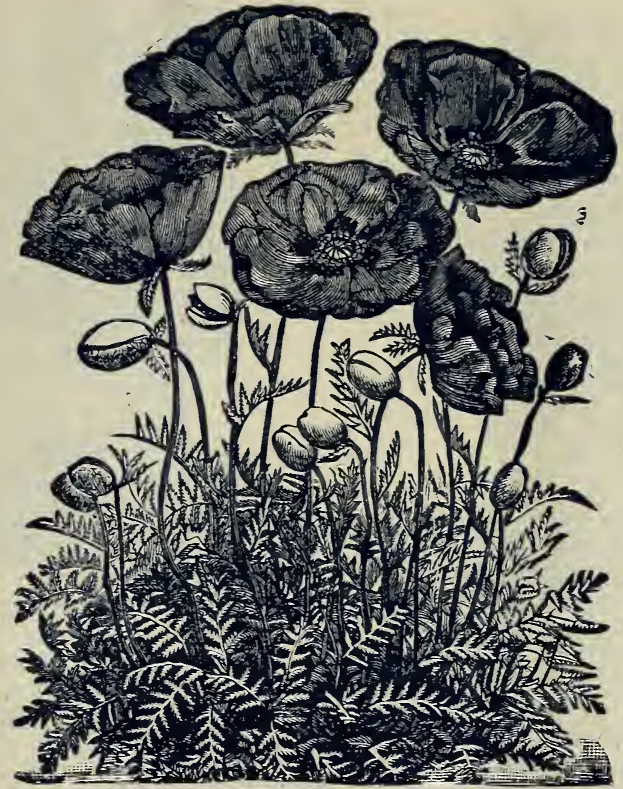

ORIENTAL POPPY.

Papaver Orientale-The brilliant "Oriental Poppy,' with large and flaming flowers of orange-scarlet.

- Bracteatum-A charming species, with immense deep blood-crimson flowers, having a black blotch at the base of each petal.

Papaver Nudicaule (Iceland Poppy)-Cup shaped; in separate colors, white, yellow and orange.

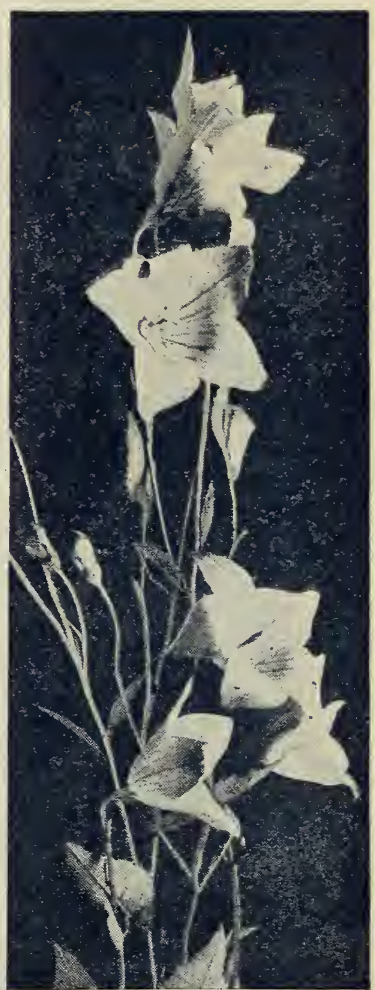

PLATYCODON.
Pardanthus Chinensis (Blackberry Lily)-Blooms from June to September, with Lily-like blossoms of range-red spotted brown. Large ornamental seeds, esembling blackberries, follow the flowers.

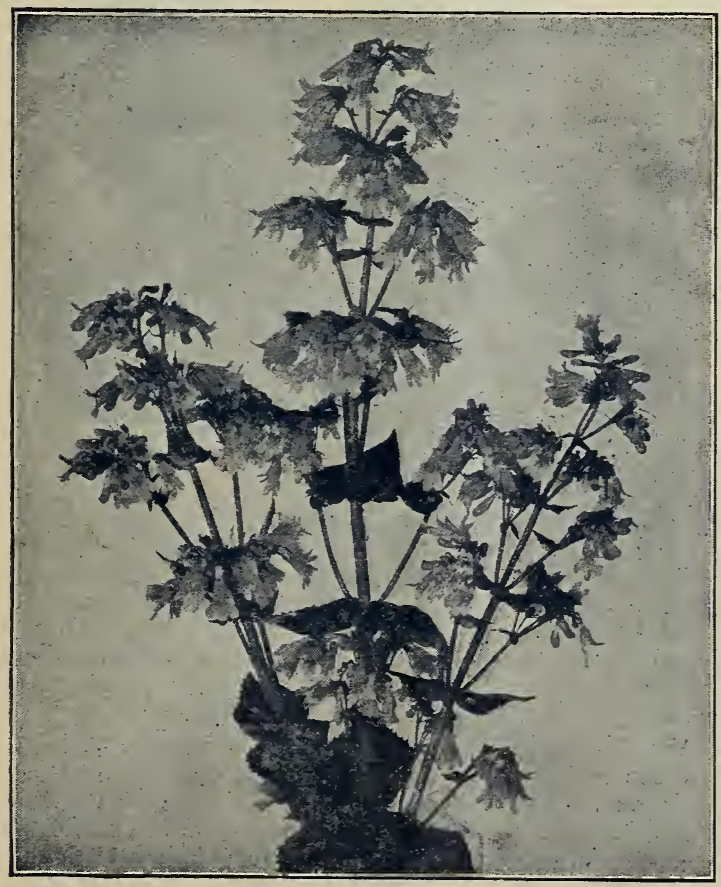

PENTSTEMON DIGITALIS.
Pentstemon Barbatus Torreyi (Scarlet Beard Tongue) -Close-set spikes of small brilliant scarlet flowers. 3 to 4 feet, July and August. $10 \mathrm{c} ; \$ 1.00$ per dozen. - Digitalis-A tall border plant, with showy white inflated blossoms on slender spikes.

Physostegia (False Dragon Head) - Handsome midsummer flowering plants, 3 to 4 feet high; bearing broad, dense spikes of tubular flowers of delicate, but conspicuous beauty.

- Speciosa Alba-Pure white. 10c; $\$ 1.00$ per dozen.

- Virginica-Rosy purple. 10c; $\$ 1.00$ per dozen.

Phlox Subulata (Moss Pink)-Low spreading stems and moss-like leaves. Flowers purplish pink.

- Subulata Alba-Flowers white.

Platycodon Grandiflorum (Balloon Flower)-Blooms constantly from July until late in September; flowers large, bell-shaped, of a deep shade of blue. An extremely rapid grower, doing well in any ordinary soil. Perfectly hardy, making a dense branching bush 2 to 3 feet high. 10c; $\$ 1.00$ per dozen.

_- Album-Pure white flowers, $10 \mathrm{c} ; \$ 1.00$ per dozen.

- Mariesi-Identical with Grandiflorum except that this is a dwarf growing sort, and blooms earlier. $10 \mathrm{c} ; \$ 1.00$ per dozen.

Plumbago Larpentae (Leadwort) - An attractive edging plant of an evenly rounded and dense growth, about 12 inches high. The tiny leaves of apple green are a rich setting for spikey red buds and clusters of cobalt blue flowers. August till frost.

Polemonium Caeruleum-The fine old "Jacob's Ladder,' which takes its name from the regular arrange. ment of pinnate leaflets upon the stem. Even without the large, bell-shaped flowers of pale blue, the plant would be worth growing for its leaves alone. - Alba-A handsome white Howered form. 


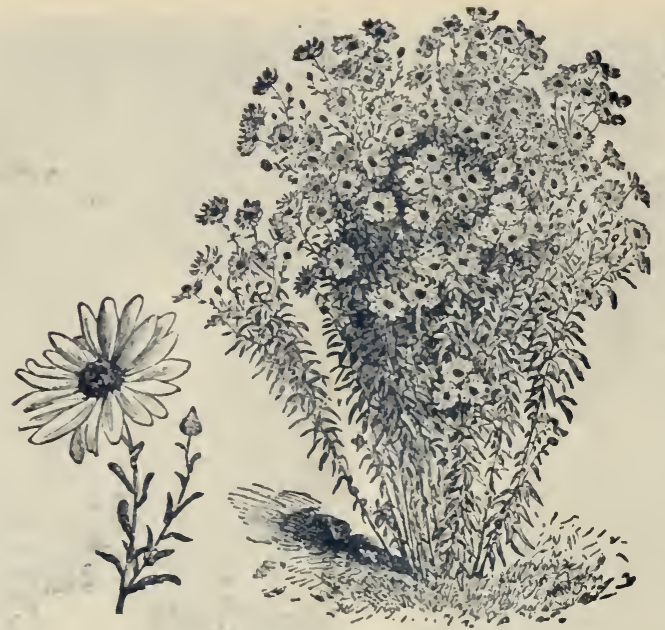

Pyrethrum Roseum-Foliage fine-cut and attractive; flowers borne profusely on long straight stems, colored in all slades of rose. A splendid cut flower and conspicuous in the garden.

Ranunculus Repens fl. p. (Crowfoot or Buttereup)-A trailing plant, useful as a grouml covering. Grows in thick mats with spreading rumers, bearing mas ses of yellow double flowers luring May and June.

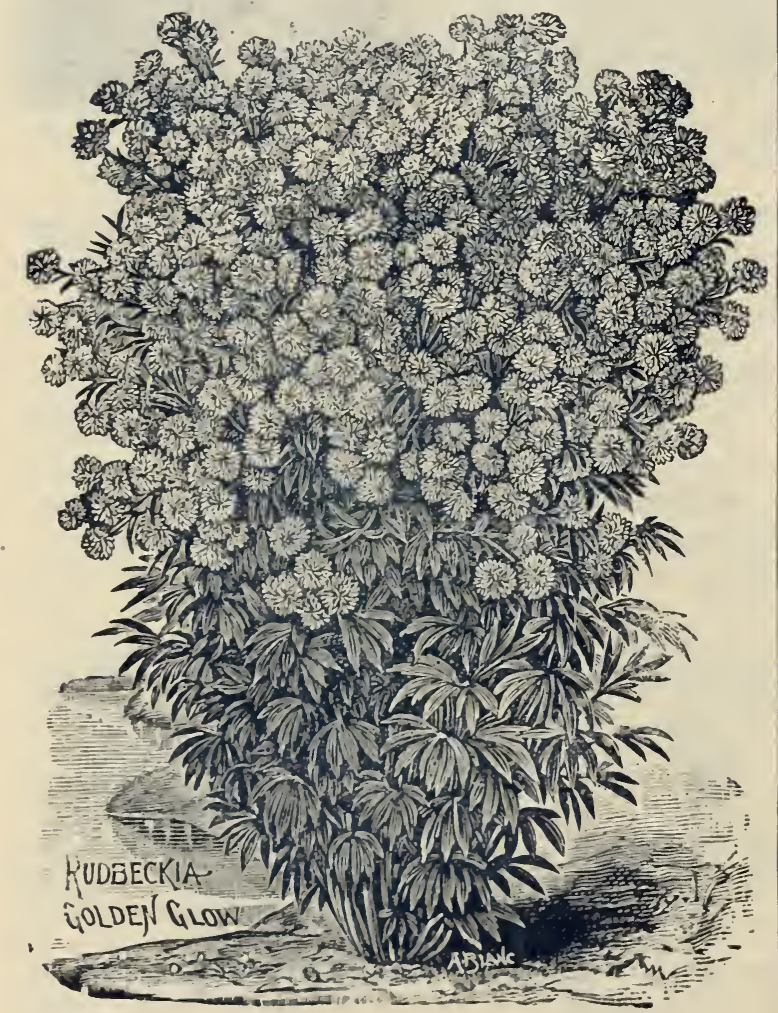

Rudbeckia "Golden Glow" - The most prolific and satisfactory hardy perennial of all yellow flowering sorts. Grows ij to 7 feet and blooms from early summer until frost. Flowers are produced on long stems in enormons quantities, and resemble goldenyellow Cactus Dahlias. 10e; 7.je jer dozen.

- Newmani-Crows 11/2 to 2 feet: plentifully supplied with broad single flowers of ormingevellow, with a prominent brown cone.

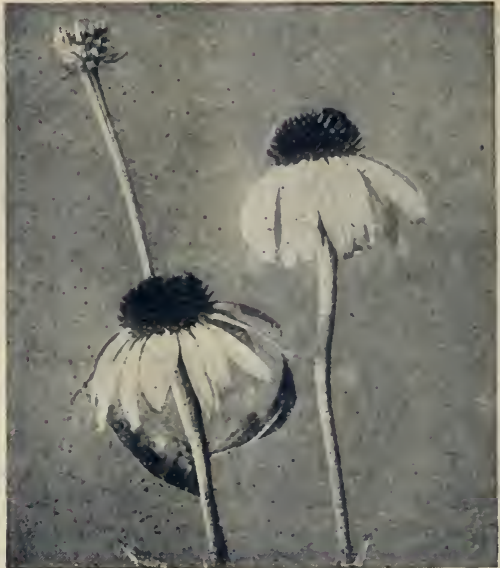

Rudbeckia Purpurea (Purple Coneflower) - Large drooping petals colored reddish-purple, with a remarkably large cone-shaped center of brown, thickly set with golden tips in spiral lines. 2 to 3 feet.

Salvia Azurea Grandiflora (Meadow Sage)-A Rocky Mountain species of Salvia, very pretty in August and September with its profusion of sky-blue flow. ers. Two to three feet.

Sedum Spectabilis (Stone Crop)-Of upright growth, 15 to 18 inches high. Foliage rounded, thick and rubbery, crowned with massive flat eymes of light rose-colored flowers.

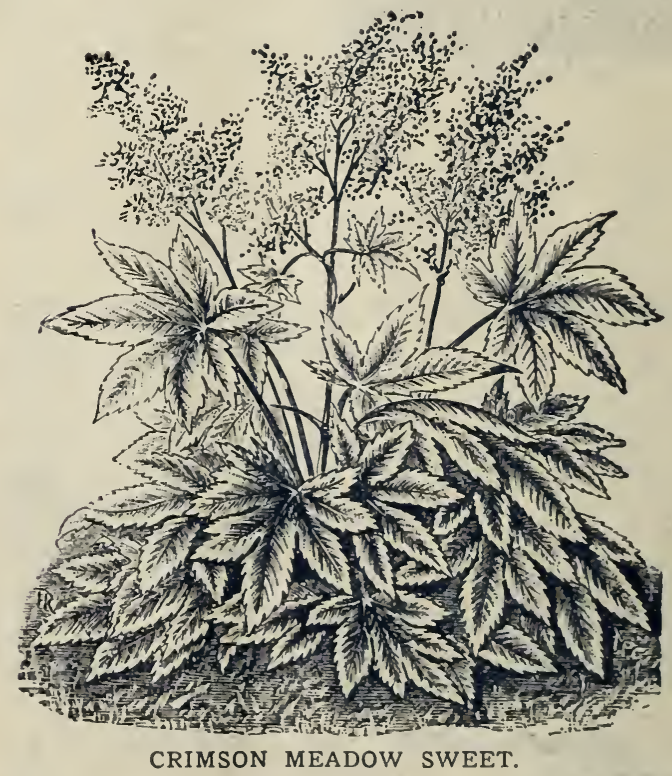

Spirea Palmata (C'rimson Meadow Sweet)-Stems and branches purple red. Flowers erimson.

Stachys Lanata (Woundwort) - A splendid edging plant for situations requiring strong foliage contrasts: the dense leafage of this variety being a sheeney silver white, with the wooly-surface and substance of felt. - Small spikes of light purple flowers appear in July and August. One foot.

Statice Latifolia (Sea Lavender) - Grows 15 to 18 inches high with tufts or clumps of thick, leathery folinge and immense panieles of delicate blue flowers. Individual flowers very minute, similar in form to the Forget-me-not, but marle into heads 18 inches or more across. Will last for months as house decoration if earefully dried. 


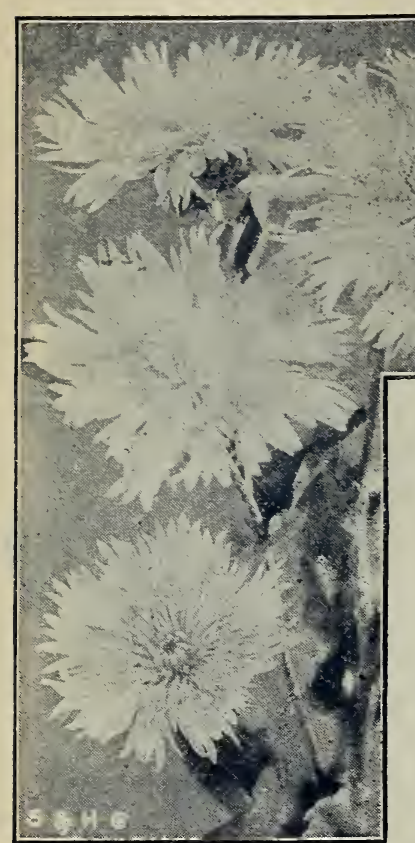

STOKESIA ALBA.
Stokesia Cyane a (Stoke's Aster)-One of the most charming hardy plants, freely blooming from July to October. Flowers of C e $\mathrm{n}$ t a u r e a shape, often measure 4 to 5 inches across, making a rich show of lavender-blue. $11 / 2$ to 2 feet.

- Alba-Equally attractive as above, with a broad show of pure white. 20c; $\$ 2.00$ per dozen.

Tradescantia (Spiderwort)-Bright and pretty plants about 2 feet tall, with richly green foliage and clustered blossoms an inch wide; in bloom all summer.

- Virginica-Deep violet-blue.

- - Alba_White.

Trillium Grandiflorum (Wake Robin) - Early spring flowering, suitable for shaded borders or sub-aquatic situations; pure white. $10 \mathrm{c} ; 75 \mathrm{c}$ per dozen.

Tritoma (Flame Flower)-The flowers of these plants combine finished elegance with an aggressive conspicuity; their size, pecular form and high coloring commanding attention from every viewpoint, while close inspection admits their refined beauty and utility-as cutflowers - for interior decoration. Rush-like foliage sup p orts smooth, thick flower stalks a yard long with a single fiery cone at the top.

U varia GrandifloraVivid orange-scarlet with orange basec o m mon ly called "Red-hot P o k e r', plant. $10 \mathrm{c}$ each; $\$ 1.00$ per dozen.

Pfitzeri - An improved type of more perfect. form, and showing a marked predominance of scarlet-the opened lower petals, merely, being rimmed $w$ i t $h$ orange.

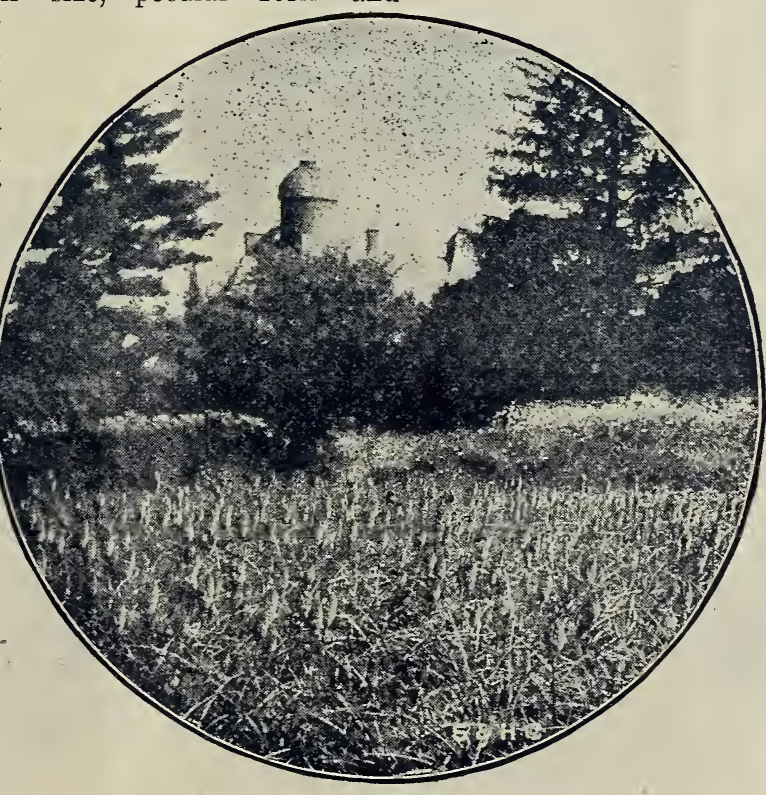

A BED OF TRITOMA PFITZERI.
Veronica (Speedwell)-An admirable species of border plants with various forms of growth, but alike in gorgeous showiness of bloom. Flowers are borne in long compact spikes of some shade of blue or white. Abundant during July and August.

- Incana-Silvery foliage; flowers amethyst blue. One foot.

- Longifolia Subsessilis - Deep blue. 3 feet. 20c; $\$ 2.00$ per dozen.

- Maritima_Long blue spikes. 2 feet.

- Spicata-Bright blue. $1 \frac{1}{2}$ feet.

- Virginica-Tall growing, with grand spikes of pure white. 3 to 5 feet.

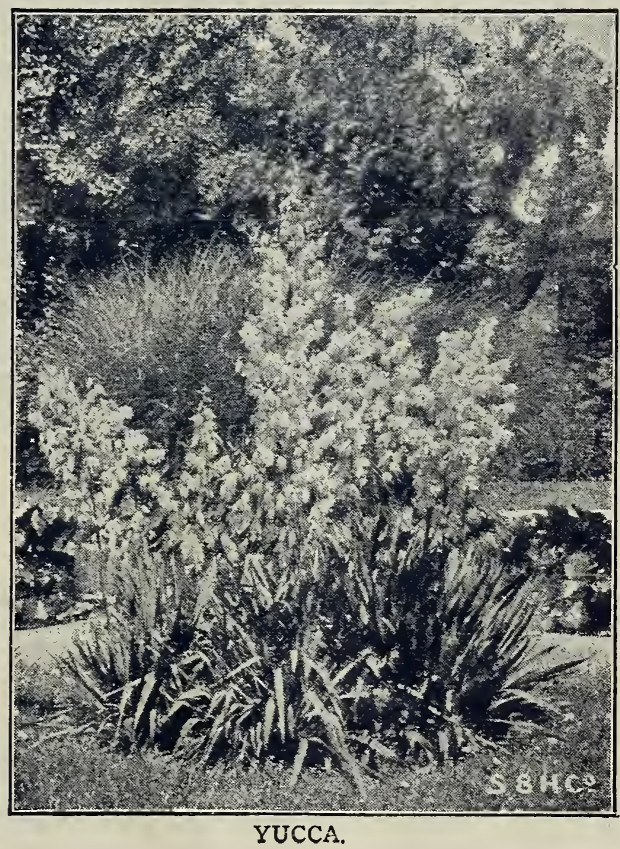

Yucca Filamentosa(Adam's Needle or Spanish Bayonet)-A stately foliage and flowering plant equally imposing in solitary or group plantings, always conspicuous. The broad sword-like foliage is evergreen; while midsummer shows great erect branching stems bearing a showy dis p lay of pendant, creamy-white bells. 10c; $\$ 1.00$ per dozen. Strong 3-year, by express, 25c; $\$ 2.50$ per dozen.

To save space, a uniform price of $15 \mathrm{c}$ each, or $\$ 1.50$ per dozen, is implied for all Hardy Perennials in preceding list, except where noted. 


\section{HARDY ORNAMENTAL SHRUBS}

Prices attached to descriptions are for one year plants, except where special mention is made. For prices of Large-sized Shrubs, see Price List in Back Part of Catalogue. 2 and 3 year Plants Must be Sent by Express or Freight.

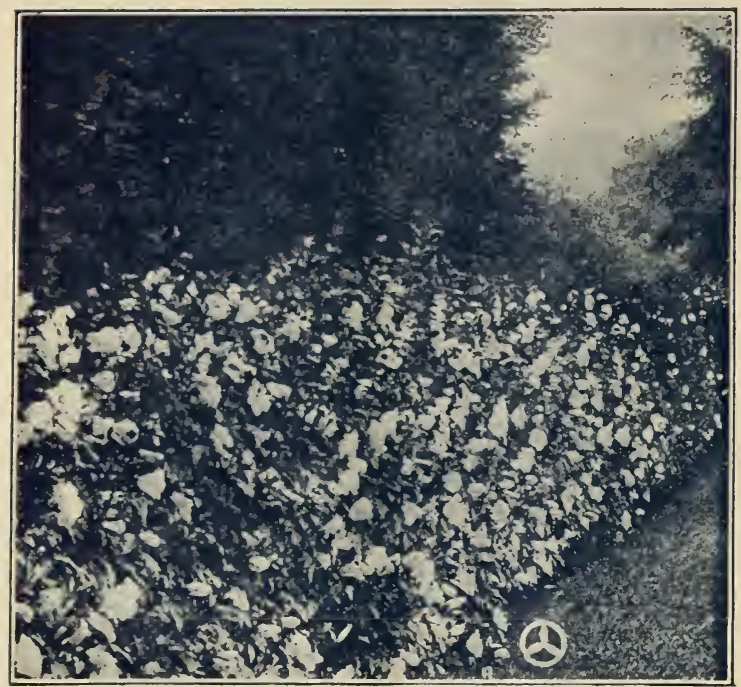

HARDY ALTHEAS IN HEDGE FORMATION.

Althea (Rose of Sharon)-Bloom late in August and September, at a time when there are so few field flowers. Flowers are large and brightly colored, much like the Hibiscus in form.

- Double Rose, Double White, and Double Purple.

- Double Variegated-Pink and white.

- Jeanne d'Arc-Double white.

- Variegated Leaved.

- 15c each; strong two-year plants, 35c.

Azalea Mollis-The most gorgeous of all hardy shrubs. The prevailing colors are orange, yellow, buff and pinkish red. Fine bushy pants, 50c; $\$ 5.00$ per 10 . By Express or Freight only.

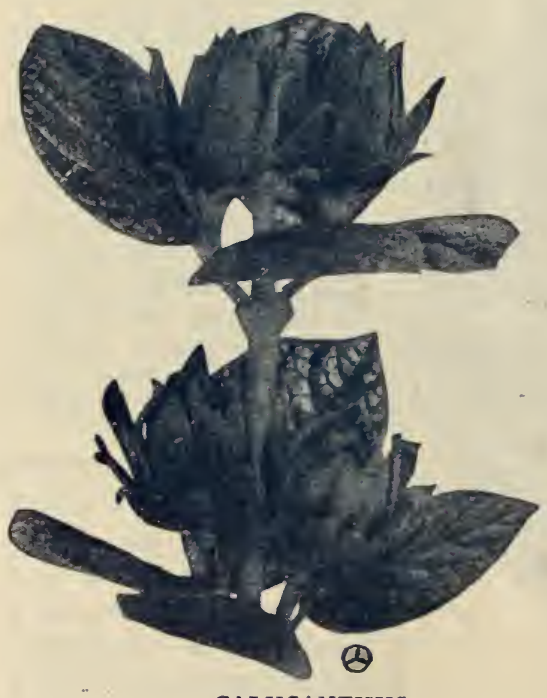

CALYCANTHUS.
Calycanthus (Carolina All. spice)-A unique shrub of quick growth, blossoming oddly at the leaf axils in double, spicily fragrant flowers of chocolate red. $10 \mathrm{c}$ each; strong 2 and 3 . year plants, $25 \mathrm{c}$ each.

Chionanthus Virginica (White Fringe)-A very showy shrub, growing to large size; with large, leathery shiny leaves, and lace-like white flowers borne in gracefully droop. ing panicles, 20c. Strong two and three-year-old plants, $40 \mathrm{c}$ each.

Cormus $\mathrm{S}$ a $\mathrm{ng}$ u in e a $-\mathrm{A}$ strong growing shrub with clusters of fine white flowers, succeeded by a fall crop of ornamental berries; the stem and branches turning to bloodred in winter. $15 \mathrm{c}$ each. Strong 2 and 3-year-old plants, 25c each.

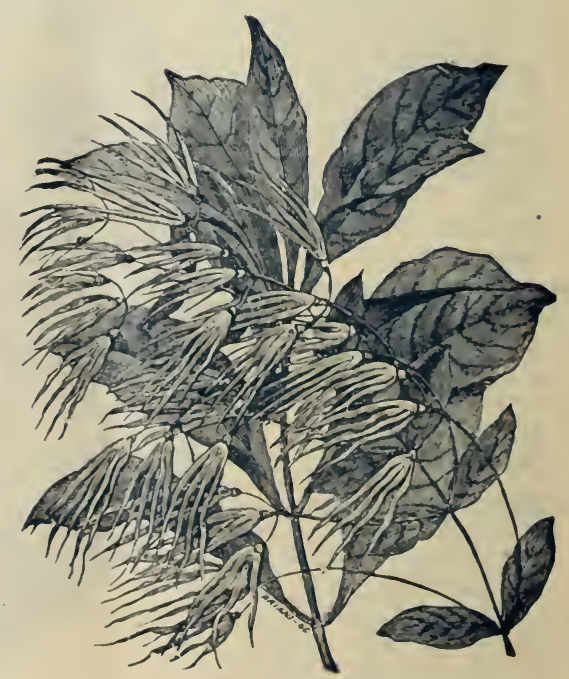

WHITE FRINGE. 


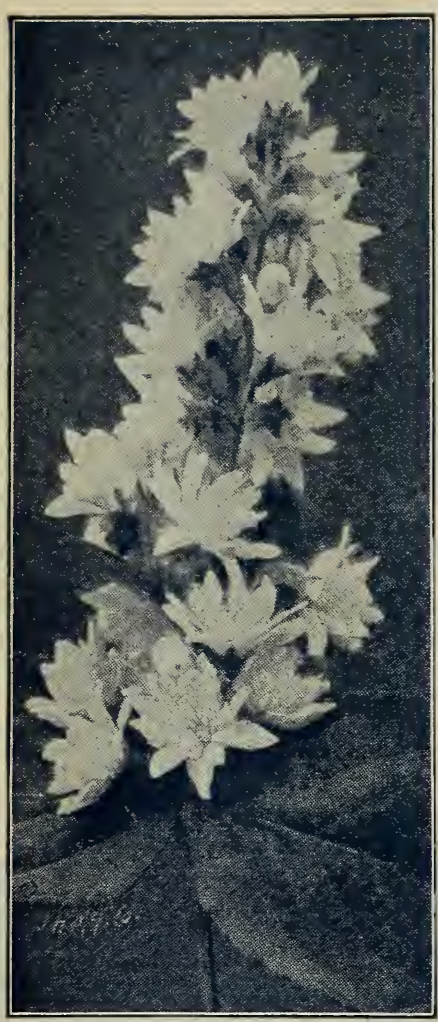

DEUTZIA CRENATA FL. PL.

Cydonia Japonica (Japan Quince)-Very early in spring this fine old shrub is completely covered with dazzling scarlet flowers; followed by small, quinceshaped fruits which are quite fragrant. Growth bushy and dense, with protecting thorns. $15 \mathrm{c} ; \$ 1.50$ per doz.

Deutzias-Valuable, self-sustaining shrubs which vary considerably in height and habit, but bloom alike in dainty bell or tassel-shaped flowers borne thickly in wreaths along their branches, in June. The taller sorts are useful for specimens, groups, and the background of shrubberies; the dwarfer for borders or for planting near the house.

- Boule de Niege-Pure white double flowers. Very dwarf. 20c. 2 and 3year-old plants, 35c.

-Candidissima-Double pure white. 15c. - Crenata - Distinct from all others; white. 15c.

- Crenata, fi. pl.-Double white tinged pi.ak. $15 \mathrm{c}$.

- Gracilis (Slender Branched) - Dwarf growing, valuable for winter blooming in pots. $15 \mathrm{c}$.

- Watereri-Probably the most popular Deutzia. Flowers pure white. 15c.

- Unless noted, strong 2 and 3-year-old plants, 25c.

Eleagnus Longipes (Japan Oleaster)-A showy shrub of strong, bushy growth, with silver variegation in the lining of its leaves, which are dark green above.

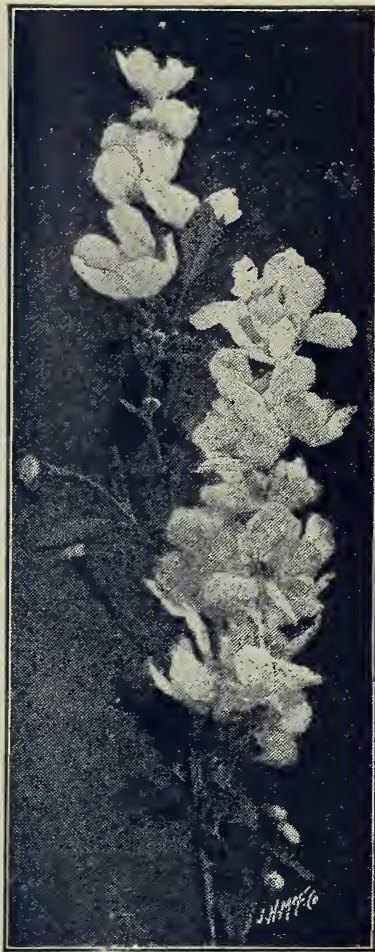

EXOCHORDA.

Its fragrant, creamy white blossoms open in April or May; the scarlet, edible fruits hang thickly aleig its branches and are ripe in July. They make delicious sauces. 15c. Strong 2-year-old plants, 35c.

Exochorda Grandiflora (Pearl Bush)-One of the most disctinctively ornamental shrubs in cultivation and a leader in its season. It grows vigorously to a height of 6 to 10 feet, and can be trimmed to any desirable shape. The early buds look like pearls strung on slender threads, May opening them up to long, gleaming sprays of pure white. 15c. Strong 2 and 3 -year-old plants, $30 \mathrm{c}$.

Forsythia (Golden Bell)-These splendid old shrubs, growing 8 to 10 feet tall eventually, light up the garden with glinting masses of yellow, very eariy in spring before the leaves appear. Their bright golden flowers, often appearing before the snow is gone, vie with the Crocus as harbingers of spring.

Forsythia Virdissima-Twisted flowers, deepest yellow, with rich, shiny green foliage. $15 \mathrm{c}$.

- Suspensa-Very long, curving branches, superbly adapted to covering arches and trellises. $15 \mathrm{c}$.

- Fortunei-Similar to the above, but of more upright growth. $15 \mathrm{c}$.

- Two and three-year-old plants, 35c each, by express.

HYDRANGEA. Paniculata Grandiflora - Too well known to require description. $15 \mathrm{c}$ each, $\$ 1.25$ per 10. Larger plants, $25 \mathrm{c} ; \$ 2.00$ per 10 . Extra large by express, 35c; $\$ 3.00$ rer 10 .

- - Tree-Shaped-Fine specimen plants four and five years old, trained to tree shape with about three feet of straight stem and nicely shaped heads. By express or freight, $60 \mathrm{c}$ each; $\$ 5.00$ per 10.

- Arborescens Grandifiora-A grand addition to the summer flowering hardy shrubs; dwarfing the show of other sorts in July and August by the magnitude and profusion of its flower-heads. The flowers are, in a large way, similar to the familiar "Snowball", in appearance, and are so conspicuously white and imposing that whether as single specimens, as cut flowers, or in groupings, their presence is predominant. 20c; $\$ 1.75$ per 10 . By express, strong, fieldgrown plants, 40e each; $\$ 3.50$ per 10 .

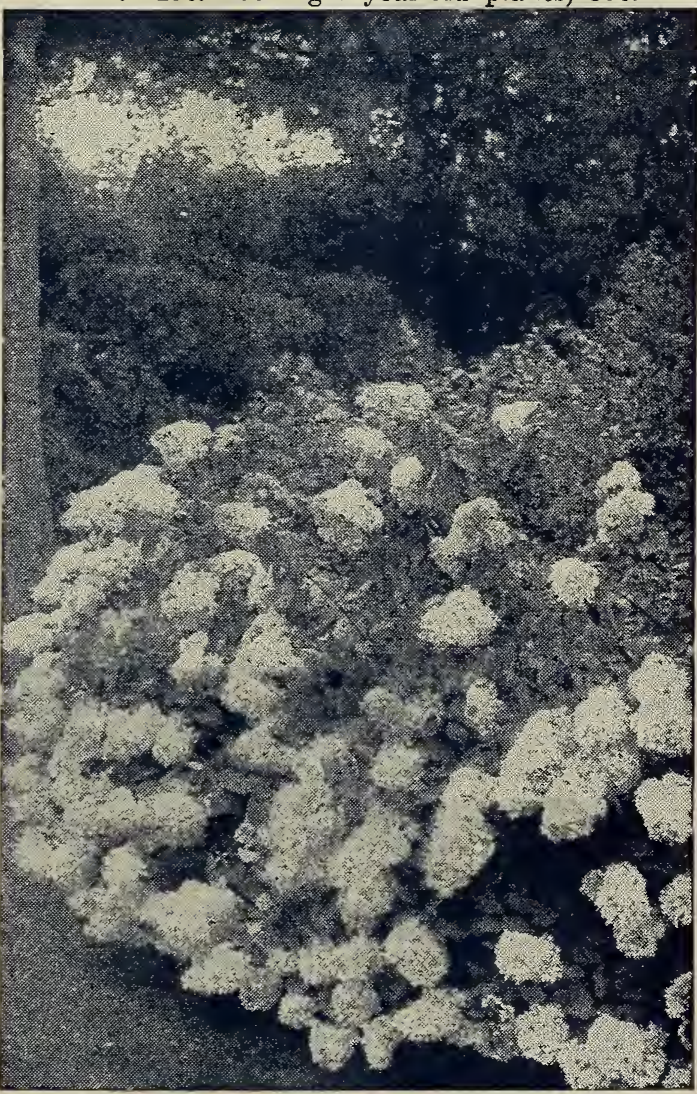

HYDRANGEA PANICULATA GRANDIFLORA 


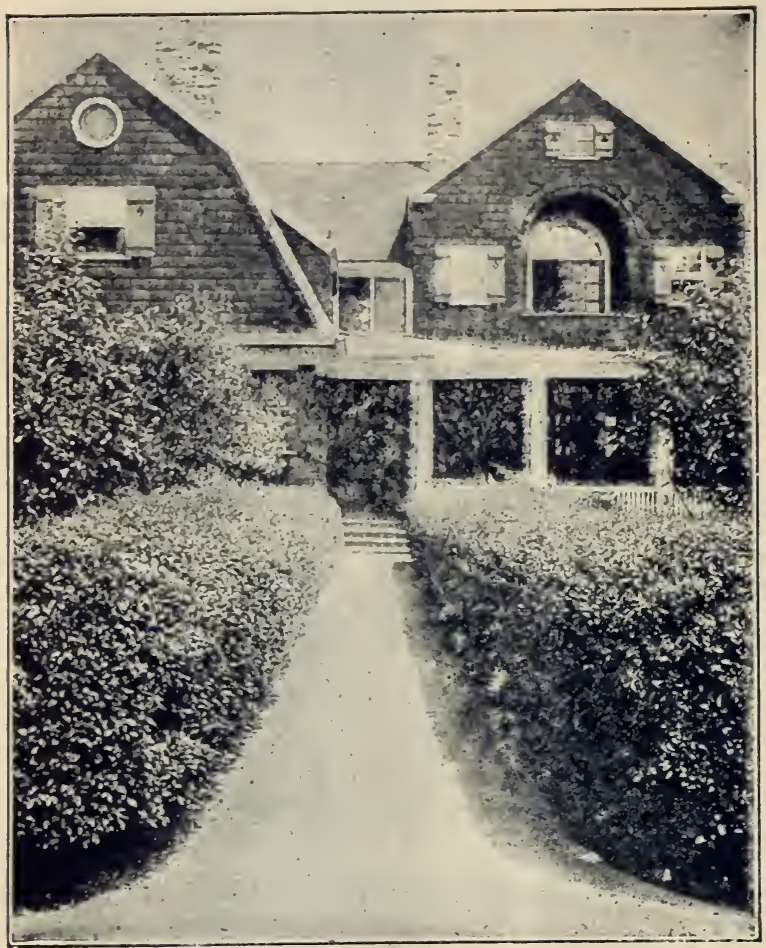

A UNIQUE USAGE FOR CALIFORNIA PRIVET.

Kerria Japonica (Japan Corcorus)-Graceful, slender; growing 4 to 5 feet; double yellow flowers. $15 \mathrm{c}$.

- Variegata-A pretty dwarf variety with small, green foliage, edged with white. $15 \mathrm{c}$.

- Strong 2 and 3-year-old plants, 25c each.

Ligustrum (Privet)-Curving branches and grayish green leaves. Their pure white flowers appear in June to be followed later by bluish black seeds.

- Amurense (Amoor Privet)-Retains its color remarkably well in the winter. Is quite hardy and makes a fine hedge. By express only. 15 to 18 inches, $15 \mathrm{c} ; \$ 1.00$ per $10 ; \$ 8.00$ per 100 .

- Ovalifolium (California Privet) - A species of unusual beauty that has become the most popular of all hedge plants. For groups and specimens it is equally pretty, and its shining leaves give it value for porch and terrace decoration when grown in standard form. Can be sheared to any desirable shape. 10e each; \$1.00 per dozen; $\$ 5.00$ per 100 .

- Regelianum (Regel's Privet)-A dense shrub with stiff, twiggy, horizontal spreading branches drooping at the ends. By express only, 18 to 24 inches, 20c each; $\$ 1.50$ per $10 ; \$ 13.00$ per 100 .

- Vulgaris (Common Privet)-The familiar slırub of old gardens, with leaves of grayish green, white flowers and shining black berries. $10 \mathrm{c}$ each; $\$ 5.00$ per 100 .

- See price list in back for prices of larger sizes and quantities.

Ionicera (Bush Honeysuckle)-The upright Honeysuckles have bright and pretty fragrant flowers, followed by showy berries that last through the fall. Make very desirable and attractive hedges.

- Bella Albida-A handsome new hybrid of strong growth. Flowers white, followed by attractive red berries. 20c; $\$ 2.00$ per dozen.
Lonicera Morrowi (Japanese Bush Hskle.)-White. 15e - Tartarica (Tartarian Red Hskl.)-Pink. $15 \mathrm{c}$.

- Alba (Tartarian White IIskl.) - C'reamy-white. $15 \mathrm{c}$.

- Grandiflora-Clear rose; frugrant. 15e.

- - Virginalis Alba-Snow white. 15c

- Strong 2 and 3-year-old plants, 25c each.

Philadelphus (Syringa or Mock Orange)-Undoubtedly one of the best and most popular shrubs. They are usually tall, vigorous growers, with large foliage and flowers, and so are valuable for backgrounds, screens, grouping and specimens. Their flowers are very sweet-scented, milk-white in most cases, and beautiful for cutting.

Philadelphus Coronarius (Garland Syringa) - A fine old form, 8 to 10 feet tall, that blooins among the earliest of the family, in very graceful sprays. Its large white flowers are delightfully scented. May. $10 \mathrm{c}$.

- - Aureus-A striking shrub of medium size, witl golden yellow leaves that remain bright through the season. Valuable for contrastive grouping. 15c.

- Grandiflorus - The most vigorous species of the group. Its long, irregular branches are clustered with snow white flowers in June. 10c.

- Gordonianus-Strong growing, large flowered white; valuable for its late blooming season in July. $10 \mathrm{c}$.

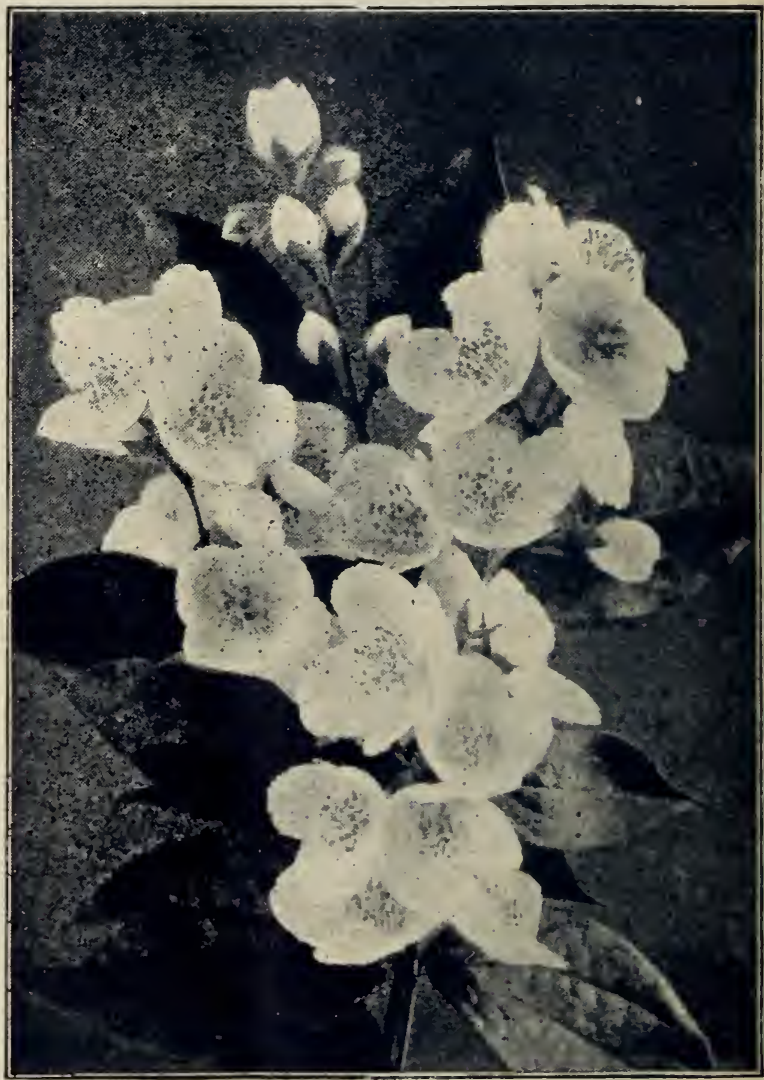

PHILADELPHUS GRANDIFLORUS.

Prunus Triloba (Double Flowered Plum)-A charming shrub of vigorous growth. Very early in spring, before its leaves appear, the whole tree is decked in a fleecy cloud of very double light pink blossoms. Its effect on a still leafless landscape is very bright. $25 \mathrm{c}$ each. 


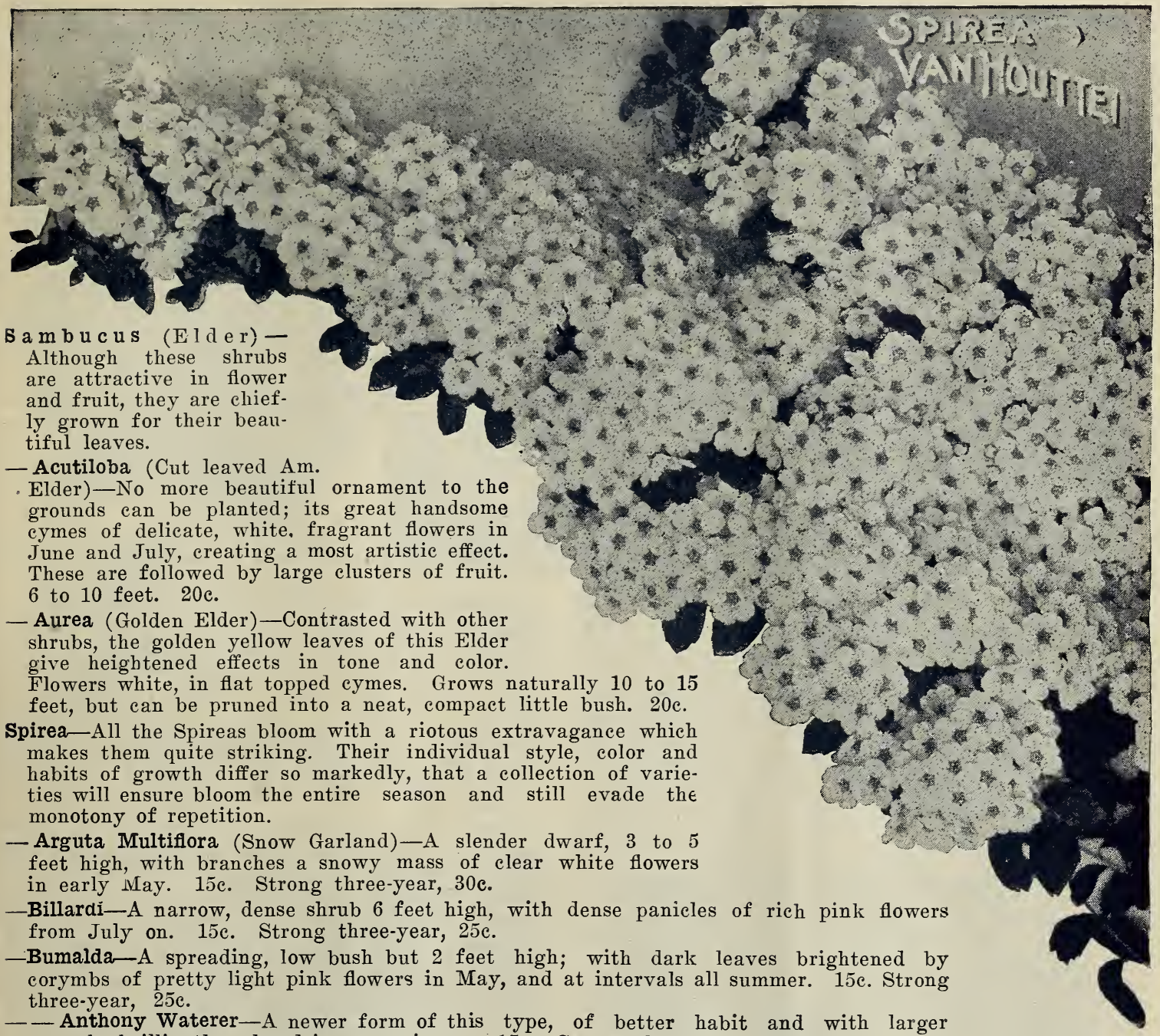

- Anthony Waterer-A newer form of this type, of better habit and with larger corymbs brilliantly colored in rosy crimson. 15c. Strong three-year, 30c.

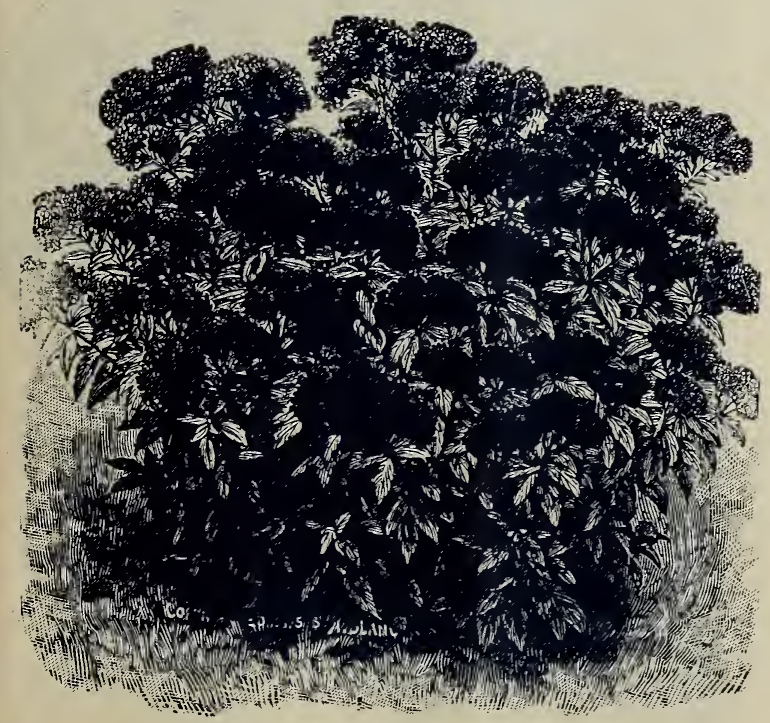

SPIREA ANTHONY WATERER
- Fortunei-Compact upright growth, 4 feet higl, with bluish green foliage, and an all summer's profusion of flat clusters; bright rose. $15 \mathrm{c}$.

- Prunifolia fi. pl. (Bridal Wreath)-Plum leaved folliage, tall growing. Blooms early, and is very effective with its long, gracefully curving branches covered thickly their whole length with small double white flowers. 25c. Strong, three-year, 35c.

- Thunbergi-Forms a dense feathery bush, 3 to 5 feet high, the foliage in autumn changing to bright red and orange. Flowers pure white, borne in feathery masses in early spring. 15c. Strong two-year, $25 \mathrm{c}$.

- Van Houtte-The grandest of all the Spireas, and one of the very best of all shrubs; a complete fountain of pure white bloom in May and June. Very popular for ornamental hedges. 15c. Strong twoyear, 25c.

- See back part of catalogue for larger sizes.

Symphoricarpus-Highly valued for ure in densely shaded situations where little else will grow and for the striking beauty of their bright, persistent fruits. $\therefore$ to 5 feet. 


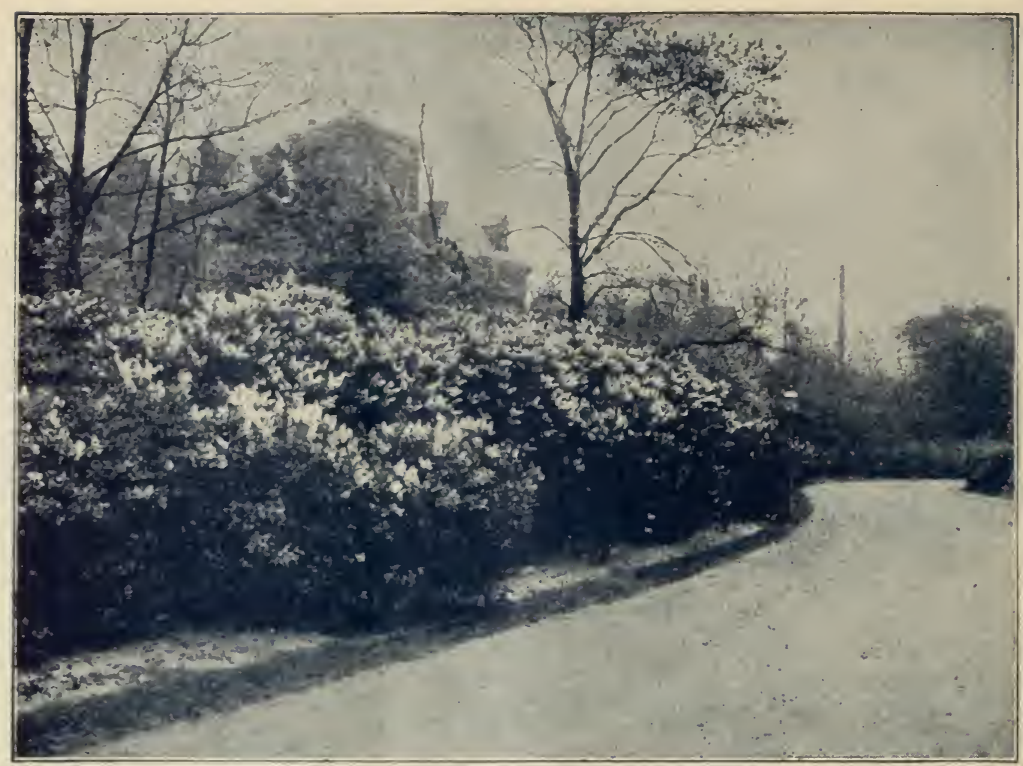

- Alba-Persion, white. 25c.

- Rothomagensis (Rouen Lilac) -Reddish purple panicles of great size and beauty. 15c.

New Double Named Lilacs-IVe offer only large sized plants. Eight distinct varieties, by express, $60 \mathrm{c}$ each; 10 for $\$ 5.00$.

Tamarix - Tall growing shrub with fine feathery foliage like that of the Juniper; small pink flowers in April or May.

- Africana_slender panicles of bright pink; reddish bark. 15x.

- Gallica-Delicate pink, nearly white flowers; leaves bluish green. 15c.

- Odessana (Caspian Tamarix) (iracefully bending, silve r. green foliage; with loose racemes of pink flowers, 4 to 6 feet. The latest to bloom. 20e. 2 year, joc.

Viburnum Lantana (Wayfaring Tree)-White flowers in large dense cymes; fruits bright red,

- Racemosus (Snowberry)-Inconspicuous, rose colored flowers in June and July; followed by large, clustered, milk white fruits which remain far into the winter. 15c. Strong two-year, 25c.

- Vulgaris (Indian Currant)-Simliar to the Snowberry except that its fruits are red, and that the smaller red berries cluster in thick ropes about the weighed-down stems. 15c. Strong two-year, 25c.

Syringa-Vulgaris (Common Lilac)-Purple. 15c. - Alba-Common white Lilac. 15c.

- Persica (Persian Lilac)-Purple. 25c.

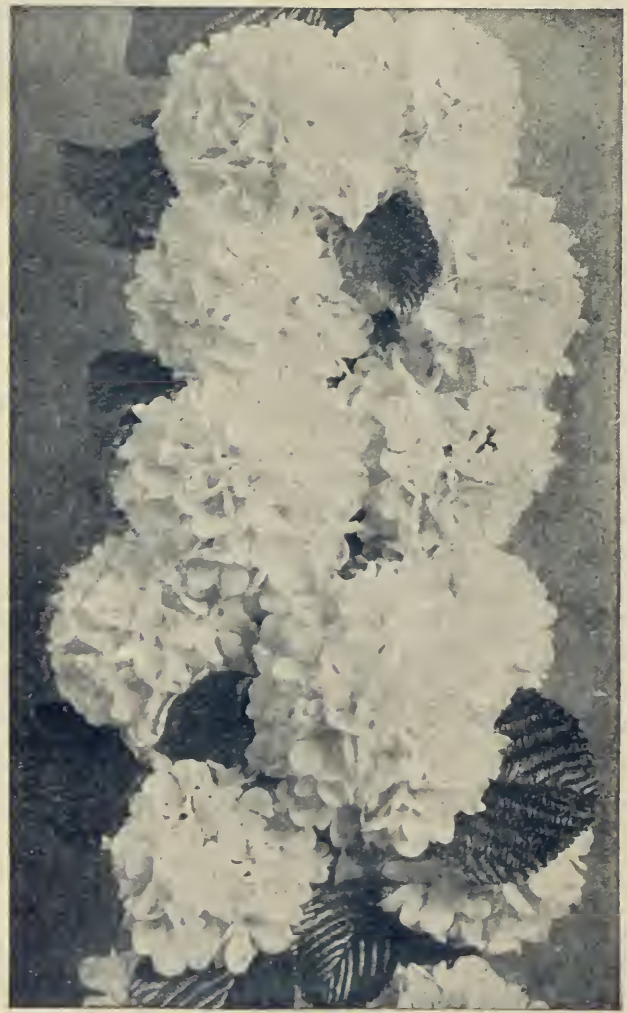

JAPAN SNOWBALL. changing to a much darker shade with age. $20 \mathrm{c}$.

- Opulus (High Bush Cranberry)-Handsome and dense foliage; flowers white in drooping flat cymes, followed by brilliant scarlet fruit in showy penclulous bunches that remain on the plant all winter. $15 \mathrm{c}$.

- Plicatum (Japan Snowball)-An erect, compact shrub, growing 6 to 8 feet. Blooms in June, and is a solid mass of white. 18 to 24 inches high, by express, $35 \mathrm{c}$.

- Sterilis (Common Snowball)-Used extensively for decorating. Flowers pure white, large balls frequently borne in clusters of five or six. 10 to 12 feet. May. 15c.

Weigela-Beautiful shrubs that bloom in May, June and July. The flowers are produced in so great profusion as almost entirely to hide the foliage. They are very desirable for the border or for grouping, and as specimen plants for the lawn.

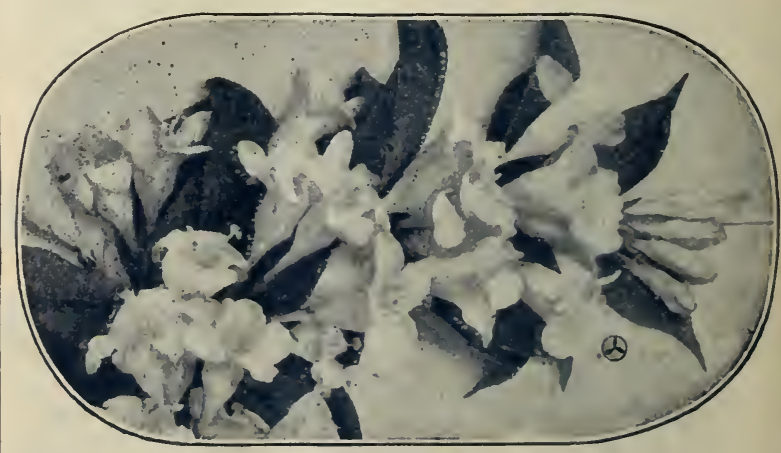

WEIGELA.

- Desbois-One of the largest. Flowers bell-shaped, pink, with orange markings in throat. $15 \mathrm{c}$.

- Eva Rathke-Flowers of dark carmine red. 35e.

- Hendersoni-A standard variety; deep rose. 15c.

- Rosea-Early flowering. Rose colored. 15c.

- Rosea Nana Variegata-Leaves margined creamy white; flowers pink. Dwarf. 15c.

- Van Houtte-Flowers broad and flat, deep rosy red with orange markings in throat. 15c.

- See price list in back of catalogue for larger sizes. 


\section{HARDY ORNAMENTAL CLIMBING VINES}

The hardy vines are a great boon to home-makers because the rapidity of their growth will in one season
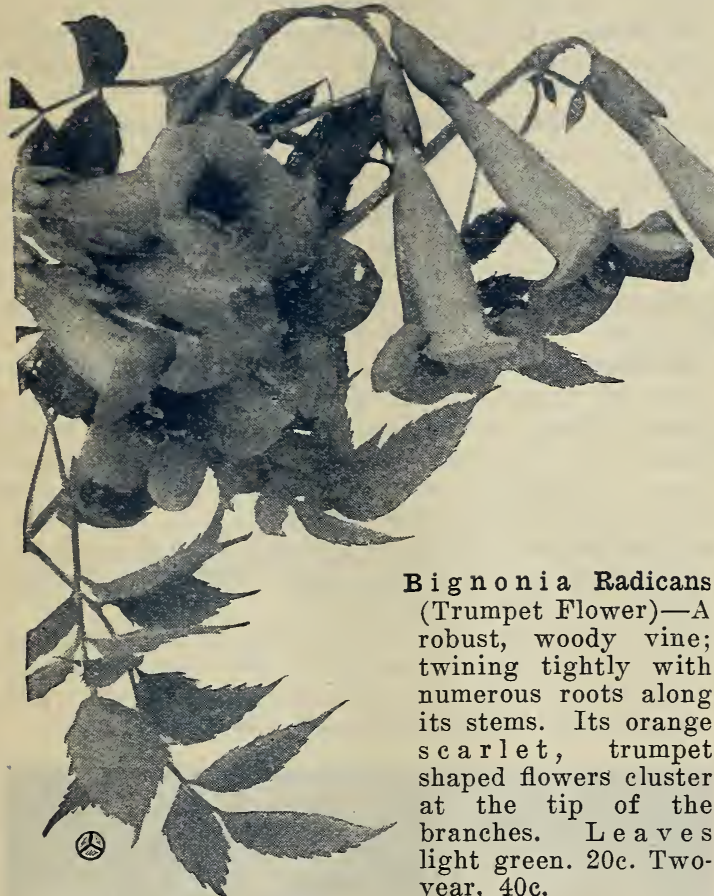

"TRUMPET FLOWER."
B ig nonia Radicans (Trumpet Flower) -A robust, woody vine; twining tightly with numerous roots along its stems. Its orange s c a r let, trumpet shaped flowers cluster at the tip of the branches. Le a ve s light green. 20c. Twoyear, $40 \mathrm{c}$.

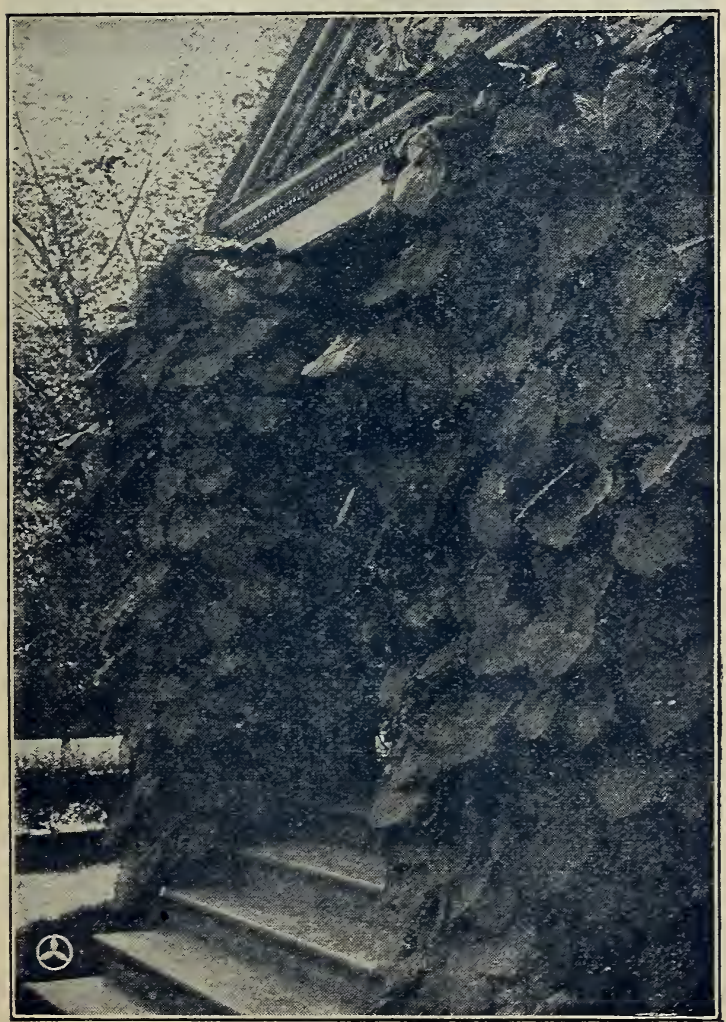

ARISTOLOCHIA SIPHO ("Dutchman's Pipe.") do much to overcome that appearance of "newness" so painfully evident in a newly built settlement; and long before trees and shrubs have become well established, will transform the general effect into one of homely comfort and affectionate care.

Akebia Quinata-A perfectly hardy, fast growing Japan vine, with magnificent foliage, producing flowers in large clusters, of chocolate purple color, possessing a most delicious perfume; unsurpassed for covering trellises and verandas, the foliage never being attacked by insects. $15 \mathrm{c}$.

Aristolochia Sipho (Dutchman's Pipe)Brownish flowers, resembling a miniature pipe; splendid for archways or verandas. Strong, one year, by express, 35e each.

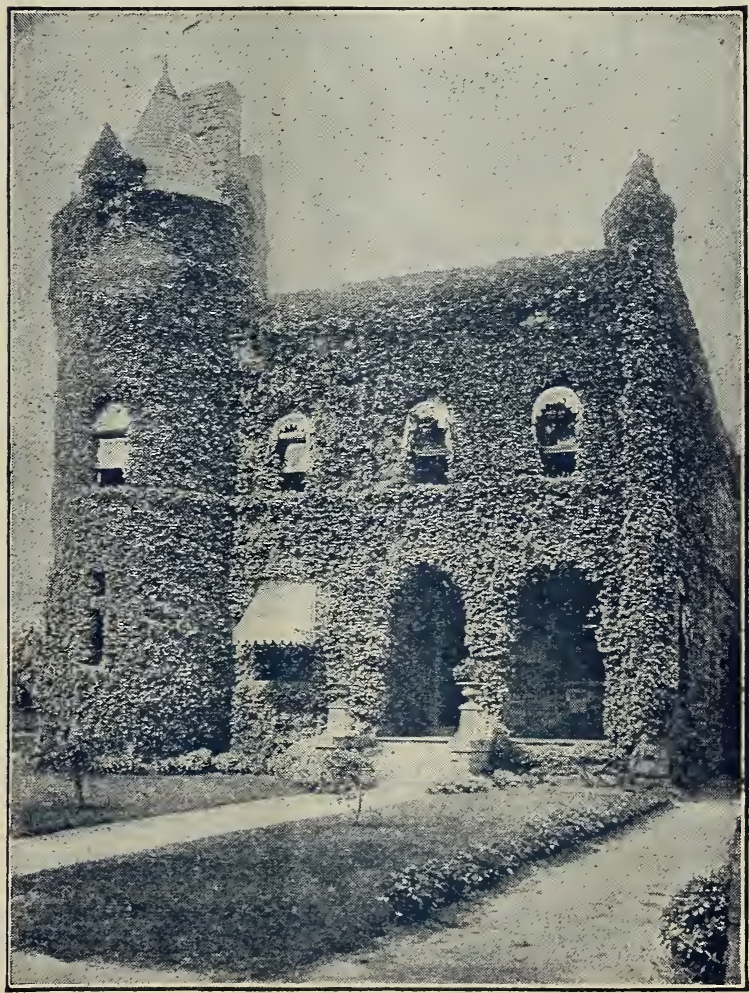

“BOSTON IVY.”

Ampelopsis Veitchi (Boston Ivy)-This is one of the finest climbers we have for covering walls, as it clings firmly to the smoothest surface, covering it closely with over-lapping foliage, giving it the appearance of being shingled with green leaves. The color is a fresh deep green in summer, changing to the brightest shades of crimson and yellow in autumn. It is hardy, and becomes more popular every year. Strong plants, $15 \mathrm{c}$ each; $\$ 1.25$ per 10 ; larger plants, 25c each; $\$ 2.00$ per 10 .

- Engelmani-Resembles Quinquefolia, but is much more dense. $25 \mathrm{c}$.

- Quinquefolia (Virginia Creeper)-15c.

Bignonia Grandiflora - Flowers two to three times larger than Radicans, with less orange color. $35 \mathrm{c}$. 


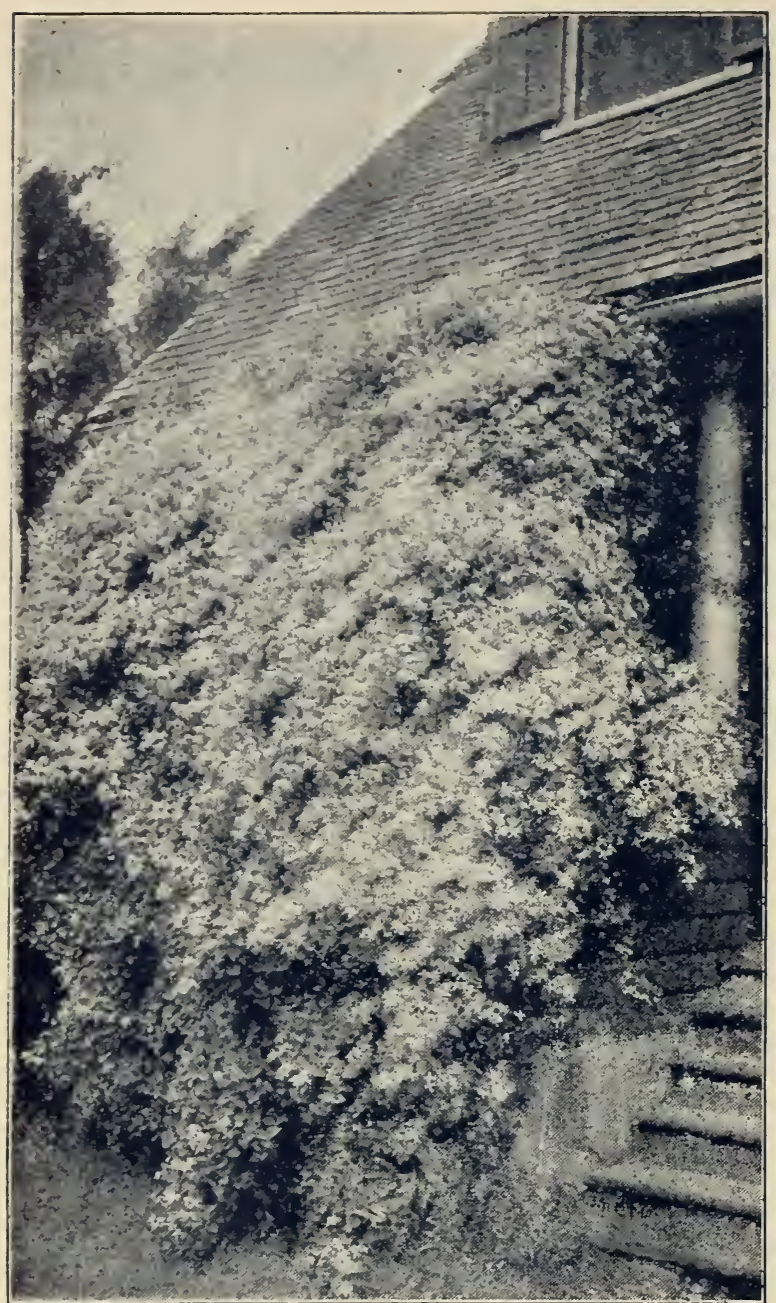

CLEMATIS PANICULATA.

Celastrus Scandens (Bittersweet)-Handsome, glossy foliage and large clusters of beautiful, orange crimson fruits retained all winter. Its graceful sprays of berries.make charning winter house decorations. $15 \mathrm{c} ; 2$-year, 35e.

Clematis-In this superb family of hardy climbers, many of the varieties have flowers 5 to 7 inches in diameter. They are grand for pillars and trellises, pegged down for bedding, and for running over rockwork, old trees and stumjs. They delight in rich soil, and a sumny situation.

- Henryi-Large ereamy white flowers

- Jackmanii-Velvety, violet purple, veined.

- Mad. Ed. Andre-A distinct crimson red.

- Ramona-Very large; color, a deep sky blue. $50 \mathrm{c}$ each; the four for $\$ 1.50$.

- Coccinea-A very handsome hardy climber, bearing thick, bell-sliaped flowers of bright coral-red. Blooms with wonderful profusion from June until frost. 25e.

- Paniculata (Sweet-scented Japan Clematis) - Of very rapid growth, quickly covering trellises and arbors with handsome, clean, glossy foliage. The flowers are of medium size, fragrant, pure white, borne in immense sheets in September, when very few other vines are in bloom.

1-year plants, $15 \mathrm{c}$ each; $\$ 1.25$ per ten.

Strong 2-year, 25e each; $\$ 2.00$ per ten.
Euonymus Radicans - One of the finest evergreen vines, with small rich green foliage, and pink fruits in cells which separate and expose the searlet arils. For covering rocky banks, rough walls, tree-trunks, ete, also for vises, baskets and borders of beds. 2-year plants, 2je each; $\$ 2.00$ per 10 . - Radicans Variegata - Foliage elged with creamy white, which takes on a finkish tinge in winter. 2 -year plants, 30c; $\$ 2.50$ per 10 .

Lonicera Aurea Reticulata (Golden-leaverl lloneysuckle)-Flowers yellow and fragrant. 10e.

- Belgica (Monthly Fragrant) - Flowers large and very fragrant; color red and yellow. 20e.

- Halleana-Color, white, changing to yellow. Fxtremely fragrant and most satisfactory. 10e.

- Japonica (Chinese Twining)-Flowers nearly white, distinet. 10c.

- Sempervirens (Scarlet Trumpet Honeysuckle) Trumpet-shaped flowers of bright searlet. 20c.

Lycium Chinense (Chinese Matrimony Vine)-Every new shoot produces handsome purple flowers and, later, a prodigions erop of scarlet berries nearly an inch long. $15 \mathrm{c} ; \$ 1.50$ per dozen.

Periploca Graeca (Silk Tine)-A rapid growing, beautiful climber, with glossy green, lanceolate foliage. Fine for arbors or trellises. 15c.

Puereria Thunbergiana (Kudzu Yine)-Large foliage and dense shade, growing 50 feet in one season. Flowers plentiful in August; rosy-purple, peashaped-in small racemes. $25 \mathrm{c} ; \$ 2.00$ per ten.

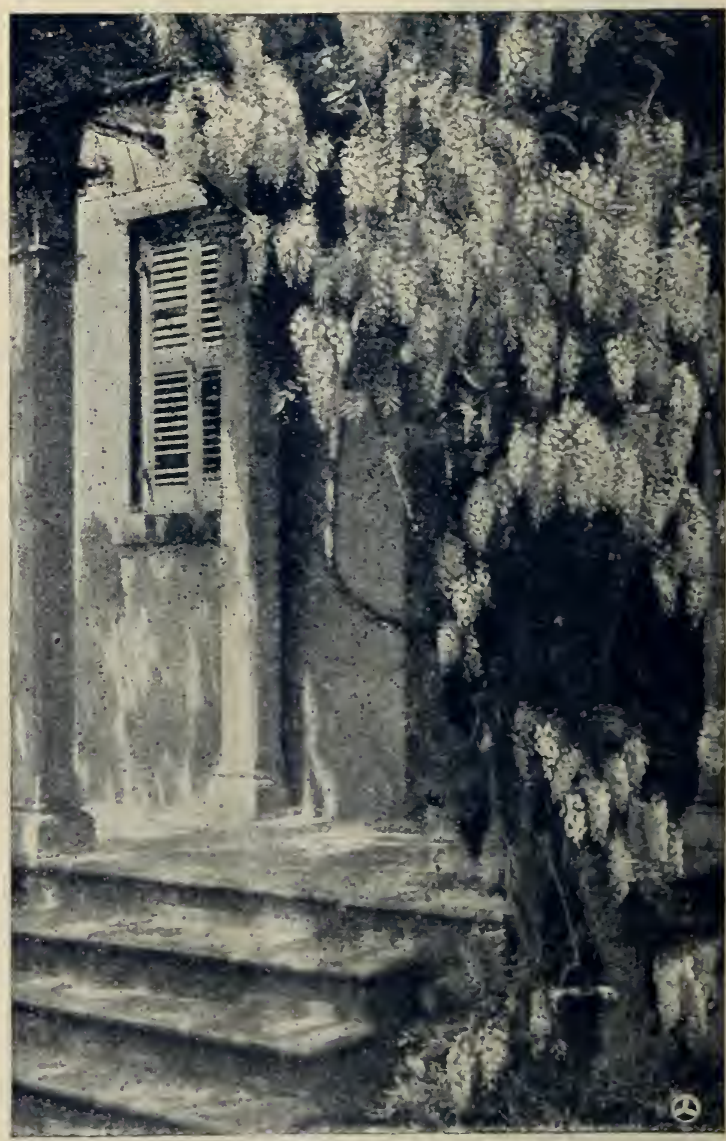

CHINESE WISTARIA.

Wistaria Magnifica - Flowers in dense, drooping racemes, of a pale lavender color. 25 c. 


\section{FRUIT TREES, GRAPE VINES, SMALL FRUITS, Etc. TERMS NET CASH}

\section{Please Note that all Stock offered in this Department is small One-Year Mail Size. For Larger Sizes see Price List by Express or Freight.}

Fall Shipping of Trees, etc.-Hardy trees, shrubs, vines, etc., cannot be safely transplanted before the first of October; are better if not dug before the last of that month or until fully matured.

All one year trees and vines, finely rooted, cut back suitable for mailing, guaranteed to reach you in good condition, with proper treatment are almost certain to live and do well. Those wishing to plant small lots, to make small investments, to save freight or express charges on long distance shipments, to plant young thrifty stock and train according to their own requirements, will find this size admirably suited to their needs.

If ordered sent by mail, postage paid by us; if by express or freight, charges paid by purchaser, but larger one year stock will be supplied. If out of varieties ordered, others of equal merit will be sent when it can be done, unless "No Substitution", is written on order.

OUR GUARANTEE-All goods are guaranteed to reach you in good condition; mistakes, if made, will be promptly rectified; examine and count on receipt and notify us at once should there be any errors or damaged stock. This guarantee will not hold good unless above requirements are complied with.

From the immense stocks stóred in our frost-proof cellars, shipments can be made at any time to suit the planting requirements of customers in any locality.

Certificate of Inspection, showing freedom of our stock from San Jose Scale and other injurious insects and disease, will be attached to all freight and express shipments.

PRICE LIST of larger $\Gamma$ zuit and Ornamental Trees, Shrubs, Small Fruits, Grapevines, etc., delivered at Freight or Express Office hc e, will be found on pages 61 to 64 . One of the largest stocks in the country of Trees for Orchard, Garden, Street, Lawn, Park or Cemetery planting in large assortment of sizes and varities. Pleased to quote pric s on receipt of list stating plainly sizes, varieties and number of each wanted.

DESCRIPTIVE CATALOGUE No. 1. A complete new, edition of one of the most comprehensive nursery catalogues published, profusely illustrated with half tone euts made from photographs of desirable specimens, containing 112 pages, giving full description of Fruit and Ornamental Trees, Small Fruits, Grapevines, Shrubs, Roses, etc., directions for planting, etc., will be mailed on receipt of 10 cents.

\section{APPLES}

Those starred $\left(^{*}\right)$ are the Russian and hardier kinds.

\section{SUMMER.}

Benoni-Yellow, nearly covered with red; juicy. Aug. Early Harvest-Medium, pale yellow, tender, juicy. Golden Sweet-Large, pale yellow, very sweet.

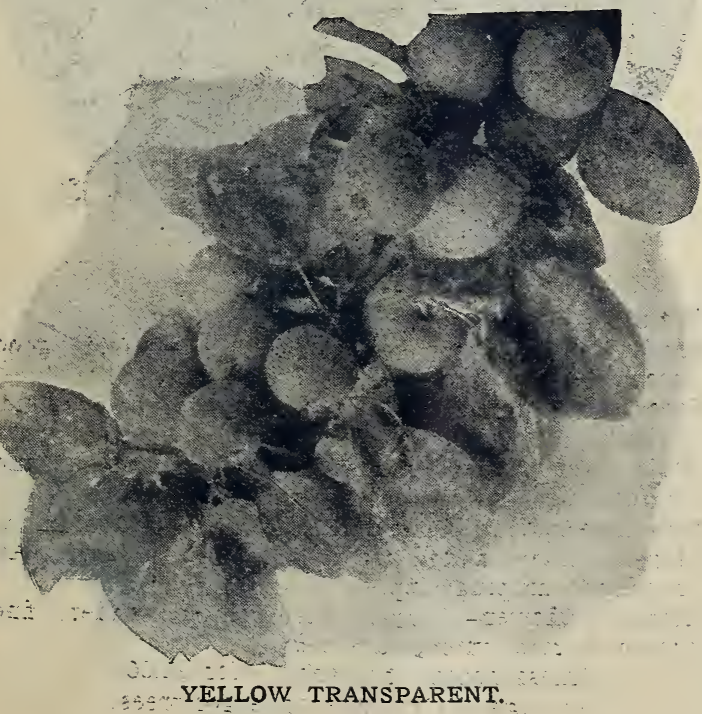

Maxson's Early-Strong grower with healthy foliage, hardy, excellent bearer. The best early summer cooking apple. In shape and appearance fruit is like Sweet Bough, but the flesh is tart, acid, good flavor and cooks perfectly tender. 20c; 6 for $\$ 1.00$.

* Red Astrachan-Large, beautiful deep crimson.

Sweet Bough-Large, pale yellow, tender, sweet.

*Tetofsky-Medium, yellow, striped red, acid.

*Yellow Transparent-Earliest and best; white, tender, juicy, sprightly, sub-acid.

\section{AUTUMN.}

Autumn Strawberry-Tender, juicy, productive.

*Duchess of Oldenburg-Good size, yellow, streaked red, juicy, rich, sub-acid, productive.

Fall Pippin-Large, yellow, rich, aromatic.

Gravenstein-Large, striped, fine quality; one of the best fall sorts.

*Haas (Fall Queen)-Large, striped, vigorous and productive.

Maiden's Blush-Large, beautiful, blush cheek.

Munson's Sweet-Good size, yellow, red cheek.

Pumpkin Sweet-Large, yellowish russet, rich.

Rambo-Medium, yellow, streaked red.

*Red Bietigheimer-Large yellow, shacied red; flesh white, juicy, with a brisk sub-acid flavor. Sept.

Western Beauty-Large, shaded bright red on pale yellow; crisp, tender, mild, sub-acid. 


\section{WINTER.}

*B a b bitt (Western Baldwin) - L a r g e, roundish, deep red, fine grained, juicy, crisp, rich fine acid.

Baldwin-Large, bright red, crisp, juicy, rich.

Banana-Fine, vigorous grower, large healthy foliage, early bearer. Fruit medium to large, smooth and handsome, golden yellow usually shaded bright crimson; flesh fine grainet, rich, s u b-a c i d, aromatic, highest quality. Onc of the best dessert apples, easily grown, a good shipper. 20c; 6 for $\$ 1.00$.

* Baxter-A strong, vig. orous grower, immense. ly productive, very hardy. Fruit uniformly large, handsome, showy red, mild acid, fine quality. 20c; 6 for $\$ 1.00$.

Belle de BoskoopLarge, yellow, shaded red, crisp, tender, juicy. Vigorous grower, pro. lific.

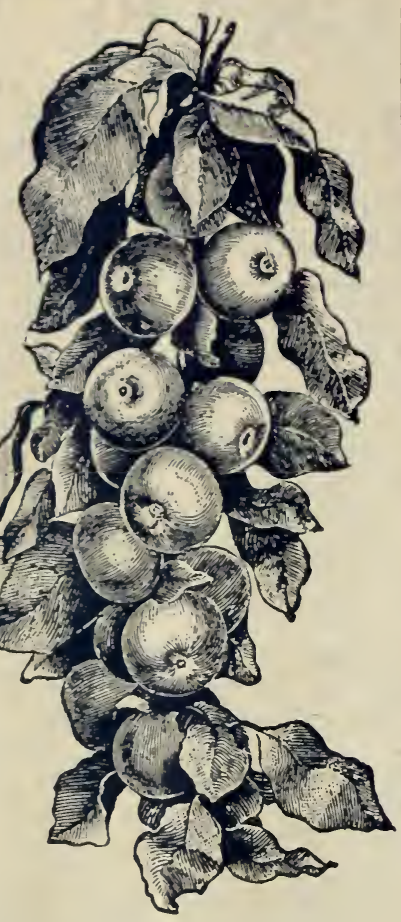

BANANA.
B e n Davis - Large, handsome, striped, valuable. *Boiken-Annual bearer, perfect foliage, vigorous grower. Fair size, yellow, tart acid, long keeper; at its best in spring when it is unexcelled for cooking.

Dominie (Winter Rambo)-Large, greenish yellow, striped red; flesh white, tender and juicy.

Danver's Sweet-Medium, yellow, good quality.

Fallawater-Large, yellowish green, productive.

*Fameuse (Snow)-Medium, deep crimson, flesh white, of best quality. 20c; 6 for $\$ 1.00$.

*Gano-An improved Ben Davis, nearly covered with deep, dark red.

*Gideon-Vigorous, early and prolific bearer. Medium golden yellow; fine, juicy sub-acid.

Golden Russet-Medium, dull russet, crisp, juicy.

*Greenville-Seedling of Maiden Blush, which it resembles, but is a late winter variety.

*Grimes' Golden-Good size, yellow, of highest quality, very productive.

Hubbardston-Large, red, striped, tender, juicy.

Jonathan-Medium, red, extra quality.

King-Large, striped, productive.

*McIntosh Red-Medium, deep crimson, highest quality, juicy, sub-acid. 20c; 6 for $\$ 1.00$.

Mammoth Black Twig-Large, dark red, hardy and productive, vigorous grower.

Mann-Medium to large, yellow, mild sub-acid.

Northern Spy-Large, striped, mild sub-acid and tender, with a rich, delicious flavor.

*Northwestern Greening-Hardy, yellow; rich, of good size, extra long keeper.

* Ontario-Large, yellow, nearly covered with bright red; juicy, sub-acid, fine.
Opalescent-Probably the handsomest apple ever put on the market. Color light, shading to very dark crimson with many yellow dots; flesh yellowish, tender, juicy and good. It is not only a beauty but all right for size, quality and productiveness, qualities rarely combined in one variety. Dec. to March. 20c; 6 for $\$ 1.00$.

Paradise Winter Sweet-Large, excellent.

Peck's Pleasant-Large, mild, rich, sub-acid.

*Peter-Resembles Wealthy in size and color, 4 to 6 weeks later. Perfectly hardy.

*Pewaukee-Medium size, bright yellow, splashed red; sub-acid, with rich, aromatic flavor.

Rhode Island Greening-Large, greenish yellow, tender, juicy, rich acid.

*Rolfe-Vigorous grower, annual bearer; handsome, red on yellow ground. Flesh yellowish, crisp, juicy,

Rome Beauty-Large, yellow, shaded red; tender, juicy, sub-acid. Popular for market in many sections.

*Salome-Long keeper, annual bearer, medium and uniform size; good quality.

*Scott Winter-Hardy and vigorous; bright red; crisp, spicy, and of a brisk acidity; long keeper.

Stark-Large, striped light and red, juicy, mild subacid. An early and abundant bearer.

Stayman's Winesap-Larger and more prolific than Winesap.

Sutton Beauty-Handsome, yellow, striped crimson, flesh tender, juicy, sub-acid, good quality, keeps well. Tree a free grower and productive.

Tolman Sweet-Medium, yellow and red, rich.

Wagener-Good size, deep red in the sun; flesh firm, sub-acid, excellent.

*Walbridge-Medium, handsome, striped red.

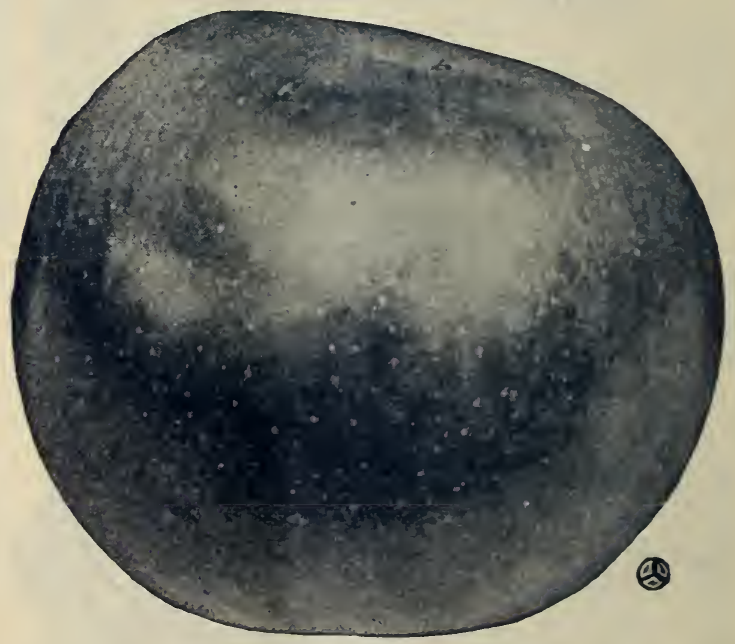

WEALTHY.

*Wearthy-Large, red, sub-acid, productive.

White Pippin-Large, yellow, tender, sub-acid; good grower and keeper.

Winesap-Medium, deep red; firm, crisp, rich, sub-acid. Widely cultivated.

*Wolf River-Large, handsome; yellow shaded, and striped red, juicy, pleasant spicy flavor.

York Imperial (Johnson's Fine Winter)-Medium to large; yellow, shaded red; firm, juicy, sub-acid. An excellent shipping apple.

Yellow Bellflower-Large, pale yellow, tender, fine grained, crisp, juicy, sub-acid.

Unless noted, 15c each; 8 for $\$ 1.00$.

See page 61 for price of larger trees. 


\section{APPLES-Crab}

Perfectly hardy, succeed everywhere, early and annual bearers, productive and ornamental.

Hyslop-Large; deep crimson; one of the most beautiful of Crabs; very popular. Oct. to Jan.

Martha-Beautiful, glossy yellow, shaded bright red, good size, mild, clear, tart. Oct.

Montreal Beauty-Large, bright yellow, shaded rich red, firm, acid; very good. Oct. to Nov.

Transcendent-Immensely productive, bright red, one of the most popular. Sept. and Oct.

Whitney-One of the largest, glossy green, splashed carmine, firm, juicy, pleasant, great bearer; excellent for cider. Aug.

Yellow siberian-Large, beautiful, golden yellow. Sept. and Oct.

$15 \mathrm{c}$ each; 8 for $\$ 1.00$.

\section{DWARF APPLES}

Very productive, usually commence bearing the second year after planting. Excellently adapted to yard and small gardens. Can furnish the following varieties: Bismarck, Baldwin, Duchesse, King, Maiden's Blush; Rambo, Red Astrachan, Wealthy and Yellow Transparent.

Too heavy to mail, must be sent by Express or Freight. $50 \mathrm{c}$ each; $\$ 4.00$ per 10 .

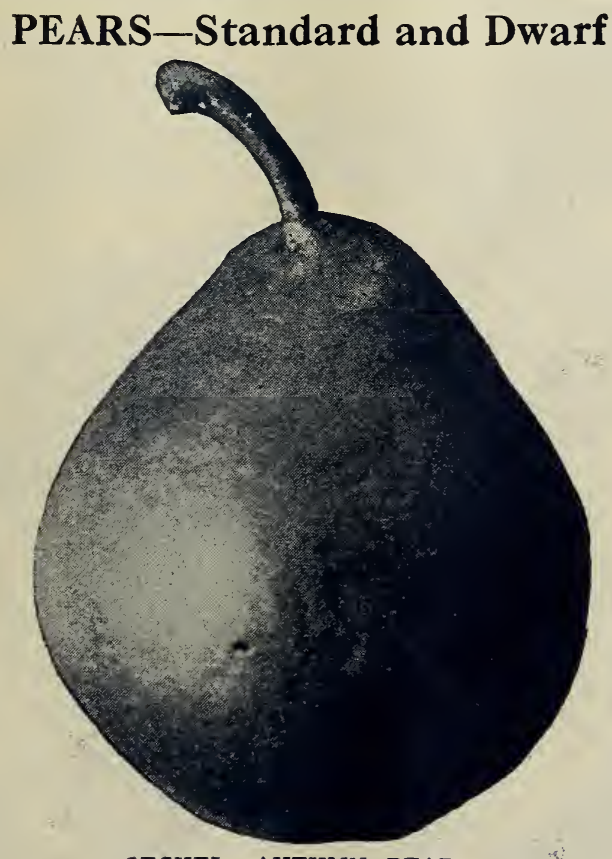

SECKEL-AUTUMN PEAR.

All can be supplied as standards, and all starred (*) can also be supplied as dwarf at same price as standards.

SUMMER.

*Bartlett-Large, buttery, juicy, high flavored, great bearer; very popular. Aug. and Sept.

*Clapp's Favorite-Very large, yellow and dull red, with russet specks, melting, rich. Aug.

Doyenne d'vte-A beautiful small pear, of delicious flavor, hardy and productive. Early Aug.

Early Harvest-Good size and color, fair quality. The best early variety in the south. July.

* Koonce-Medium, yellow with carmine cheek. A profitable early market variety. July.
Margaret-Medium, greenish yellow, with red cheek, melting, juicy, vinous, best quality. Aug.

*Tyson-Medium, melting, juicy, good. Aug.

*Wilder-Small to medium, yellow, shaded carmine, fine grained, tender, sub-acid. Vigorous grower, early and annual bearer, very productive, good quality. Early Aug.

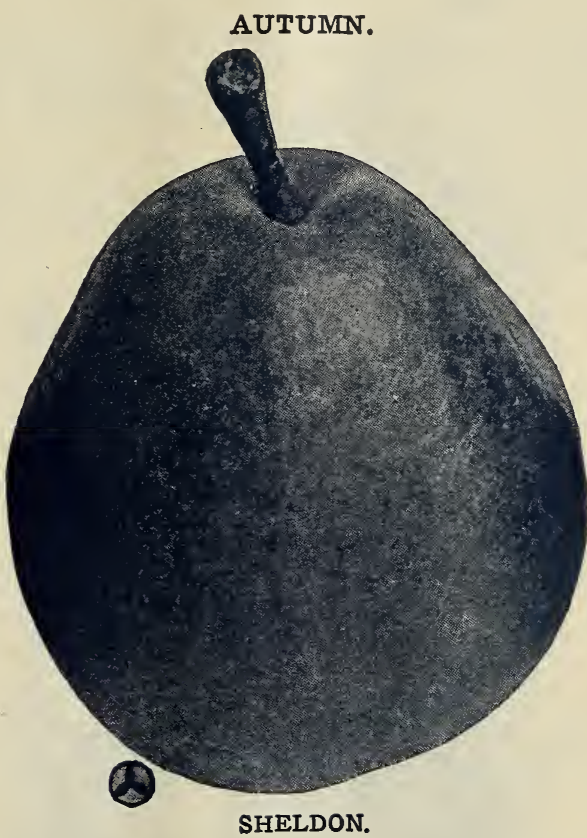

*Angouleme (Duchess) - Very large, buttery, rich, juicy, excellent. It succeeds to perfection and is the most popular market variety as a dwarf. Oct. and Nov.

*Anjou-Large, buttery, melting, rich, vinous. The best late fall and early winter variety. Oct. to Jan.

Belle Lucrative-Fine large fruit, melting, and delicious; productive. Sept. and Oct.

Clairgeau-Its large size, early bearing, productiveness and great beauty make this one of the most valuable market sorts. Oct. and Nov.

Columbia (Bartlett-Seckel)-Tree vigorous, hardy and productive. Fruit good size, rich quality, high color, handsome and good. Sept. and Oct.

Flemish Beauty-Large, juicy, rich; one of the hardiest and most popular. Sept. and Oct.

Garber-One of the Japan Hybrids; earlier and larger than Kieffer; hardy, productive, early bearer, excellent for canning. Sept. and Oct.

*Howell-Large, yellow, with red cheek, rich, sweet, melting, early bearer, productive. Sept. and Oct.

* Kieffer-Its large size, handsome appearance, and remarkable keeping and shipping qualities make it exceedingly profitable for market. Oct. and Nov.

*Louise Bonne-Good size, greenish yellow, with a bright red cheek. Sept. and Oct.

Onondaga (Swan's Orange)-Vigorous and productive. Large, rich, yellow, buttery, melting, juicy. Oct. and Nov.

*Seckel-Small, skin rich yellowish brown, when fully ripe, with deep brownish red cheek; flesh very fine grained, sweet, exceedingly juicy, melting, buttery; one of the richest and highest flavored pears known. Tree a moderate grower. Sept. and Oct. 
Rossney-Ripens about two weeks after Bartlett, averages larger, excellent keeper and shipper, uniform size, shine and color, one of the handsomest; creamy skin with erimson blush; flesh melting, juicy, sweet and tender, of superior flavor. A vigorous grower, hardy both in wood and fruit bud, and very productive. Combines excellent quality with large size, fine form and superior shipping qualities. 35c; 3 for $\$ 1.00$.

Sheldon-Medium size; yellow, witl a richly shaded cheek; flesh a little coarse, melting, juicy, with a very brisk, vinous, lighly perfumed flavor; of first quality. Tree vigorous, erect and handsome, hardy and productive. Oct.

*Vermont Beauty-Tree liardy and vigorous, early and abundant bearer. Fruit medium yellow with red cheek; rich, juicy, best quality. Oct.

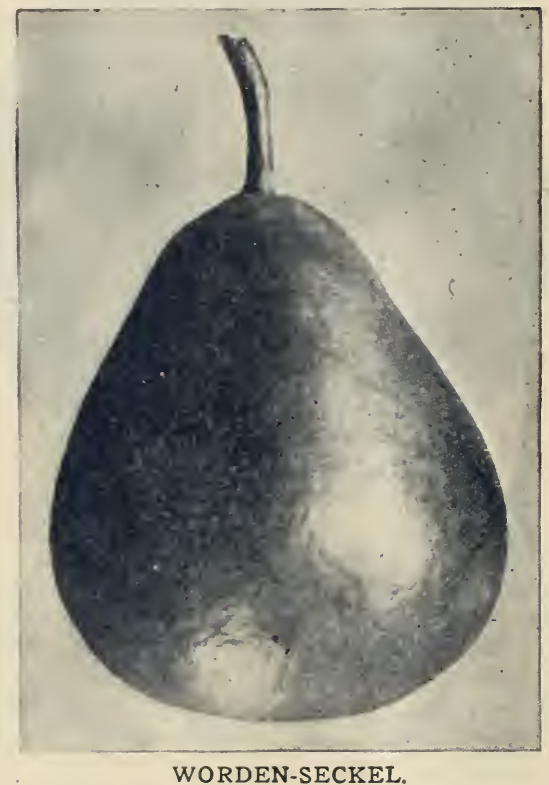

*Worden-Seckel-A seedling of the Seckel. Equal in quality to its famous parent which it much resembles: in flavor, while in size, color, form and appearance it is decidedly superior. In color, when well-ripened, it closely resembles Clapp's Favorite. Tree a more upright and rapid grower than Seckel; hardy and an enormous bearer; fruit keeps well; retaining its quality to the last. Oet. $35 \mathrm{e} ; 3$ for $\$ 1.00$.

\section{WINTER PEARS}

Bordeaux-Large, size; long keeper; melting, juicy, rich. Dec. to March.

Easter-Large, yellow with red cheek; fine quality. Dec. to Feb.

*Lawrence-Medium, vellow, with brown dots, melting, pleasint and aromatic. Nov. and Dec.

*Pres. Drouard - Large, melting, juiey, with delicato perfume. Tree hardy and vigorous. Feb. to Mareh.

Unless noted, 30c each; 4 for $\$ 1.00$.

See page 61 for price of larger trees.

\section{CHERRIES}

We know of nothing in the fruit line that has been giving or promises to give in the future larger returns than a cherry orchard. Few markets are ever over supplied.

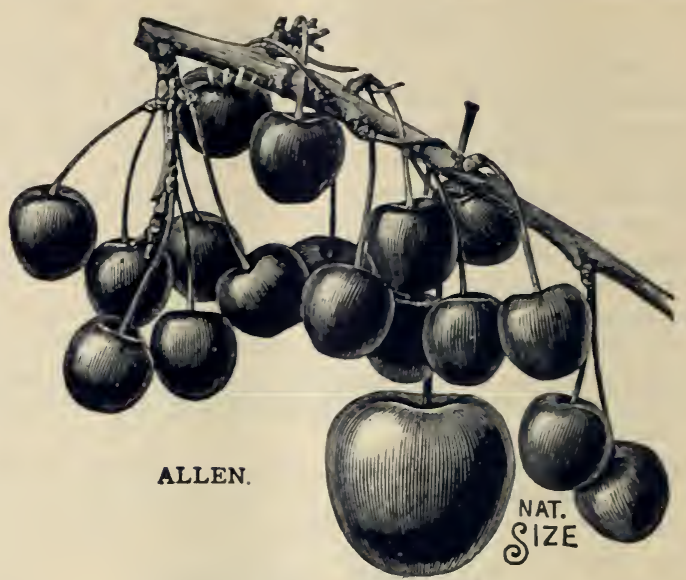

Sweet varieties are starred *.

*Allen-Of excellent quality; large size, nearly heart shape, shining and smooth; color when ripe nearly black, very meaty and firm; so far free from all rot and disease; ripens late. July.

Baldwin-Large, round, slightly sub-acid, sweetest and richest of the Morello type. A fine upright grower, remarkable for earliness, hardiness and productiveness. June.

*Bing-Very large, dark brown-almost black; flesh firm, sweet, rich and delicious. On the Pacific coast where this variety originated it is considered one of the most profitable sorts. July. $35 \mathrm{c} ; 3$ for $\$ 1.00$.

*Black Eagle-Large, tender, juicy, rich. July.

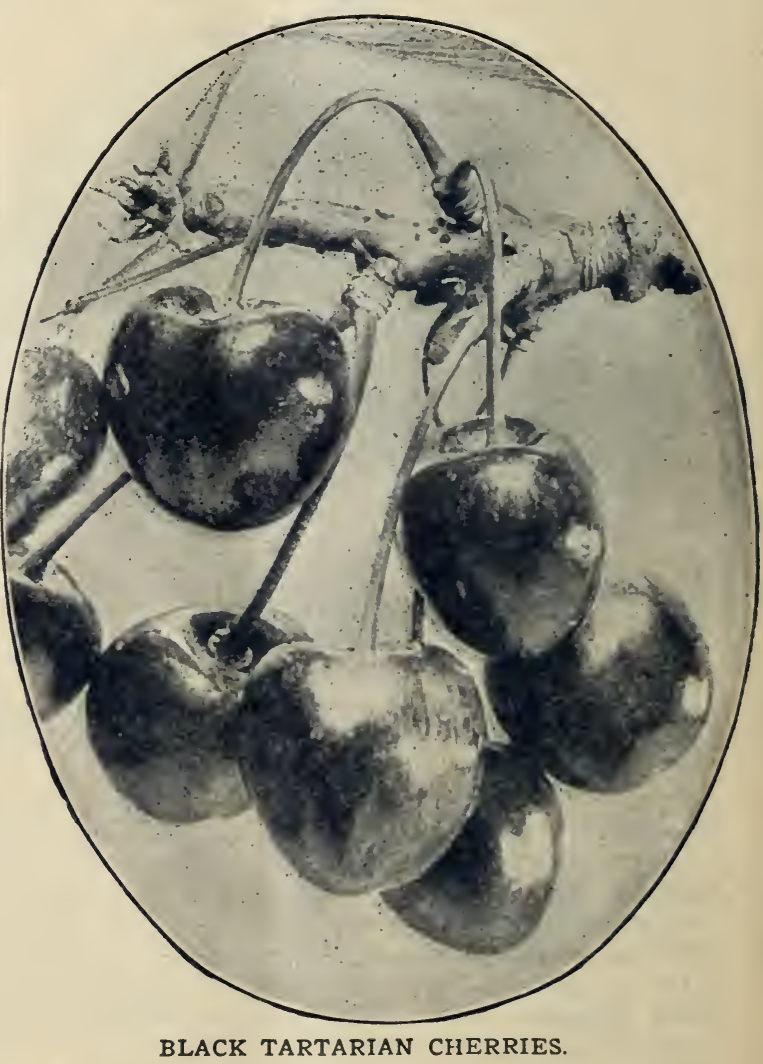

Black Tartarian-Very large, black, juicy, rich, excellent, productive. Last June. 
*Dikeman-From Northern Micl. The original tree is still producing immense crops; fruit large, black, firm, of excellent quality; fine keeper and shipper; probably the latest of all Sweet Cherries,

Dyehouse-A very early and sure bearer; ripens a week before Early Richmond. June.

* Early Lamourie-Earliest of all; good size, dark pur ple, juicy, rich, excellent. June.

Early Richmond-Medium, dark, red, melting, juicy, sprightly, rich, acid, best. June.

*Elton-Large, pale yellow, fine flavor. June.

Empress Eugenie-Large, dark red, juicy, rich. robust and productive. July.

English Morello-Fair size, blackish red, rich acid, juicy, good. Aug.

*Gov. Wood-Large, light red, juicy, rich, delicious. Tree healthy and productive. June.

* Lambert-One of the largest of all; heart shaped, dark purplish red, turning to almost jet black when fully ripe. Flesh firm, solid, rich and juicy, with sprightly flavor; seed very small for so large a fruit. Tree rugged, strong grower, hardy, enormous bearer. Late July. 35c; 3 for $\$ 1.00$.

Large Montmorency-Large, red, productive, ten days later than Early Richmond. Late June.

Late Duke-Large, light red, late. July.

Louis Phillipe - Large, dark red, almost black, sprightly, mild acid; stone small. July.

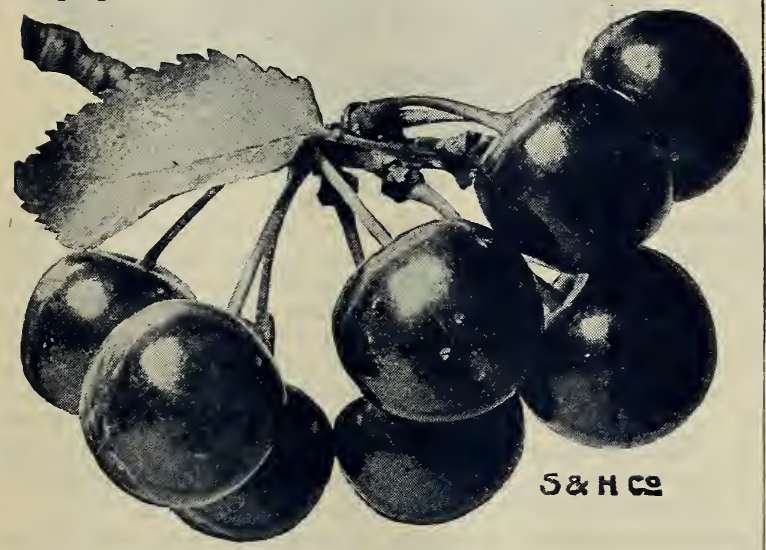

MAY DUKE.

May Duke-Large, red, juicy, rich. June.

Montmorency Ordinaire-Large, red, acid, exceedingly productive. Late June.

* Napoleon-Large, pale yellow or red; firm, juicy sweet and productive. July.

Ostheimer-A perfectly hardy, late blooming, immensely productive variety. Large, heart-shaped, nearly black when ripe; juicy and rich. Aug.

Reine Hortense-Large, bright red, juicy. July.

*Rockport-Large, pale amber, light red in sun, sweet, good. Tree erect; beautiful. June.

*Schmidt-Immense size, deep black, flesh dark, tender, very juicy, fine flavor; productive. July.

Vladimir-A Russian sort, very hardy; strong grower, wonderfully prolific. Fruit about size of Early Richmond; mild, sub-acid, juicy. Middle July.

*Windsor-Fruit large, liver-colored, distinct, flesh remarkably firm and of fine quality. Tree hardy and prolific. A valuable late variety. July.

Wragg-Very hardy, vigorous and productive, medium, dark purple, fine quality. Aug.

*Yellow Spanish-Large, yellow and red. June. Unless noted, 30c; 4 for $\$ 1.00$.

\section{PLUMS}

Archduke-Large, black, prolifie, valuable addition to late varieties for lome use or market. Early Oct.

Bradshaw-Large, dark red, flesh green, juicy, productive, fine for market. Aug.

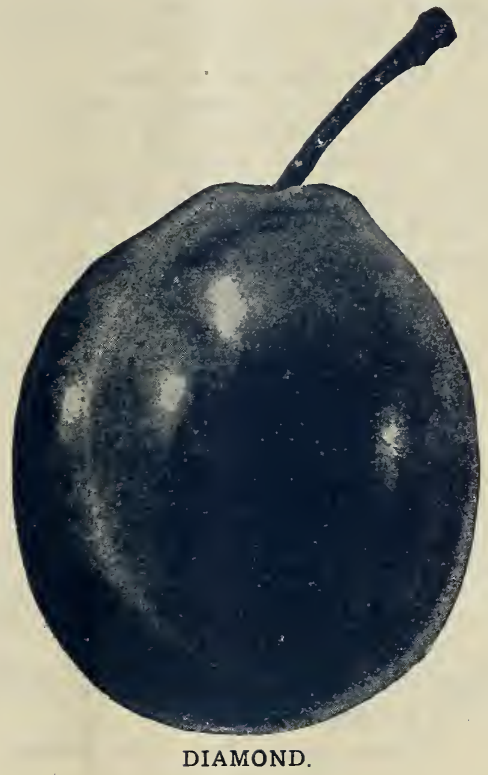

Diamond-A large, magnificent plum, one of the most attractive, enormous size, dark purple with a beautiful bloom. Tree very vigorous, productive and hardy. Sept.

Gen. Hand-Large, yellow, sweet and juicy. Sept.

German Prune-Large, dark purple, good. Sept.

Grand Duke-Color of Bradshaw; fruit very large, of fine quality, free from rot; very productive. Tree moderate grower. Late Sept. 35c; 3 for $\$ 1.00$.

Gueii-Large, bluish purple, flesh yellowish green, rather coarse; sweet, pleasant. One of the best market varieties. Sept.

Imperial Gage-Large, pale green, juicy, sweet, rich and excellent. Aug.

Italian Prune-Good size, purple, juicy, delicious, fine for drying. Sept.

Lombard-Medium, violet red, juicy, good, hardy and productive, the leading market variety. Aug.

Mary-Good size, yellow with delicate white bloom, highest quality; fine, sturdy, spreading grower; too delicate for long shipment; one of the very best for home use.

Monarch-One of the most valuable of the late introductions from England. Tree robust, dense foliage, an abundant bearer. Fruit very large, roundish, oval, dark purplish blue, perfect freestone. Follows Grand Duke in ripening. Oct.

Moore's Arctic_Small, purplish-black, juicy, sweet; immense bearer; one of the hardiest in bud and bloom. Sept. 35c; 3 for $\$ 1.00$.

Othello-A purple-leaved Burbank plum. A rare combination of the useful and the beautiful. A wonderful new fruit and ornamental tree; one of Luther Burbank's ereations. The tree is an upright grower, and a prolific bearer; fruit deep crimson, about one inch in diameter, ripening before the very earliest of ordinary plums. The foliage is of the most brilliant reddish purple, and holds its color throughout the season. $50 \mathrm{c}$ 
Pearl-A seedling of the French Prune, surpassing that variety in size; fruit is handsome, flattened, white, semi-transparent, with heavy white bloom. In honeyed sweetness combined with an attractive flavor and fragrance it excels all other prunes or plums. $50 \mathrm{c}$.

Peters' Yellow Gage-Large, oval, bright yellow; rich, juicy, fine quality. A good grower. Sept.

Pissardi or Purple Leaved-A small sized tree with very rich purple leaves, carrying their color through the season; the most desirable purple leaf tree or shrub for ornamental planting.

Pond-A magnificent plum, red, changing to violet, one of the most attractive. Sept.

Reine Claude (Bavay's Green Gage)-Very large, greenish, fine flavor. Sept.

Shipper's Pride-Large, dark purple; very showy, often measuring 2 inches in diameter; fine, juicy and sweet. Sept.

Shropshire Damson-Medium, dark purple, very productive; best for preserving. Oct.

Sugar Prune-A seedling of the French Prune grown by Luther Burbank. Tree is far superior to the French Prune, better in growth, foliage, form and productiveness. Fruit even in size, very large; flesh yellow, tender and very rich in sugar juice; color at maturity dark purple covered with a thick white bloom; ripens early. $40 \mathrm{c}$.

Yellow Egg-Very large, egg-shaped, productive, excellent for cooking. Aug.

Unless noted, 30c; 4 for $\$ 1.00$.

\section{JAPAN OR ORIENTAL PLUMS}

Varieties marked (H) are, or are supposed to be, hybrids. All these sorts are the productions of Luther Burbank, of California, who has produced thousands of crossbred seedlings, the ones offered being the best of all.

Abundance (Botan)-One of the oldest and best known Japanese varieties; hardy and productive. Fruit large, lemon yellow, with heavy bloom; good quality. Aug.

America (H) -Fruit 'much larger than the popular native sorts. Bright golden-yellow with pink blush, flesh yellow, moderately firm, good quality. In growth and appearance tree resembles our natives; productive, bears young, should prove hardy and succeed wherever plums can be grown. A good keeper, ripening before Robinson.

Burbank-The best and most profitable among growers for market; ripens 10 to 14 days after Abundance. Tree hardy, sprawling, vigorous grower, unequalled in productiveness; bears young. Fruit large, excellent quality; cherry red with lilac bloom. Aug.

Chabot-Medium to large; cherry red, flesh yellow, sweet, of excellent quality; very prolific; one of the best of Japan plums. Farly Sept.

Chalco (H)-An exceedingly strong grower, one of the most productive, hardy. Fruit almost stemless, surrounding the older branches like Simoni, tomato shape, large, flat, deep reddish-purple, flesh yellow, firm and meaty, sweet and fragrant, extra quality, none of the peculiar Simoni flavor. Ripens little before Burbank.

Climax (H)-Extremely vigorous, upright grower. Productive as Burbank, four times as large, two weeks earlier and higher color. Fruit large as an ordinary peach, deep dark red; skin firm; flesh yellow, sweet, rich, fruity of fine quality. One of the earliest to ripen. Mr. Burbank regards this as one of his most valuable productions. 35c; 3 for $\$ 1.00$.
First (H)-One of Mr. Burbank's productions, who says it is a combination eross between several native and Japan varieties; that it is the earliest of all plums, and the largest, handsomest and most productive of all my early plums. Color, pale yellow, slightly flushed red, with conspicuous light bloom, cling-stone, good texture, sweet, juicy and well flavored. July.

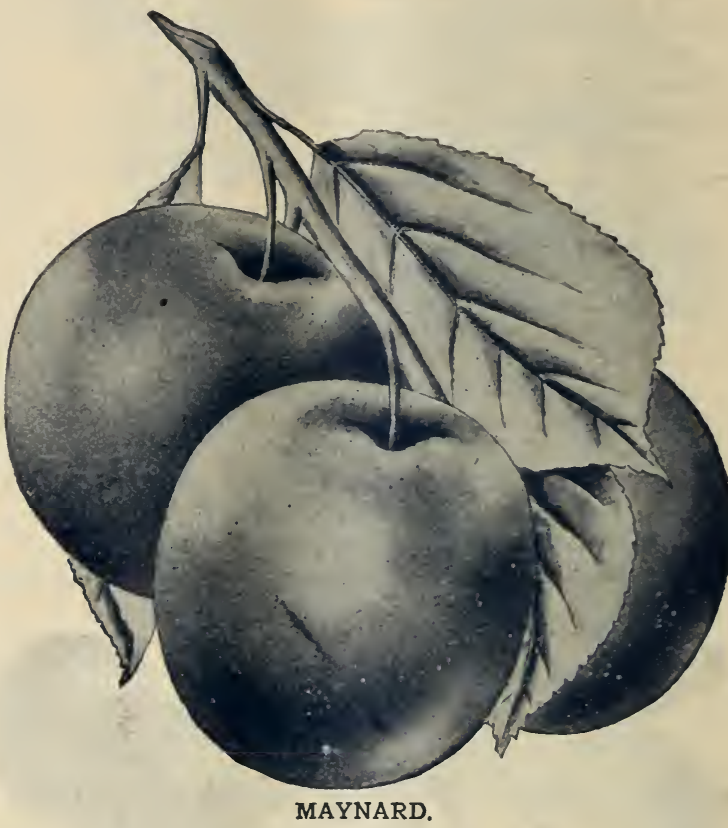

Maynard (H) - One of Luther Burbank's latest introductions, and said to be the nearest perfect of this class of plums. "A sturdy, strong and very rapid grower, with heavy luxuriant foliage. It fruits heavily every year, not over-hanging but yielding a full satisfactory crop, bearing its burden of fruit on the inside of the tree. Fruit is verv large, nearly round, color deep dull red, thin whitish bloom. Flesh firm, melting and juicy, rich and sweet, extra fine quality. Its shipping qualities are unsurpassed.", Follows Climax in ripening. 35c; 3 for $\$ 1.00$.

October Purple-A strong, vigorous grower, said to be one of the hardiest of the Japan varieties. Productive, of good quality, a large, round, late purple plum, especially recommended for late market.

Red June-Recommended as "by all odds the best Japanese plum, ripening before Abundance." One of the vigorous, upright growers; productive; fair size, vermilion red; pleasant quality. Ripens after Willard, a week before Abundance. Aug.

Satsuma (Blood)-Large, globular, with sharp point. Color, purple and red with blue bloom, flesh firm, juicy, dark red or blood color, fine quality; pit very small. Hardy and vigorous grower. Aug.

Shiro (H)-A strong grower, wood hardy and wiry, ripening early, should prove of great value in sections too cold for some of the best sorts. Fruit is produced in profusion, medium to large, clear light yellow with thin white bloom, so transparent the pit can be seen through the flesh, which is firm, juicy, rich, pleasant sub-acid; ripens two weeks before Burbank and nearly as productive.

Simoni (Apricot Plum)-Fruit bright red, flat; flesh yellow, firm, of little value only as a novelty. Sept.

Santa Rosa (H)-The latest and introduced as the best of Luther Burbank's plum productions. We quote from the introducer's description: "Tree a strong, vigorous, upright grower, resembles the 


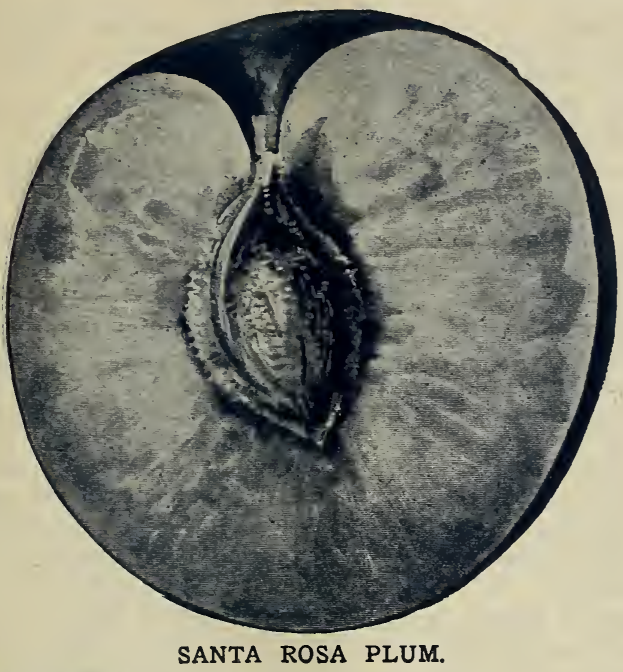

Santa Rosa-Continued.

Wickson in habit with larger and more abundant foliage. Fruit uniformly large, averaging six inches in circumference each way; as a shipper it is the peer of them all-'standing up' under the most trying conditions; color deep purplish crimson with blue bloom; flesh purple, shaded scarlet; pit small; the eating quality is unequaled, rich, fragrant, delicious; ripens with the earliest two weeks before Burbank." Awarded a gold medal at the Lewis and Clark World's Fair. Has been thoroughly tested in the west; we recommend it for trial in the east wherever Japan plums succeed. 35c; 3 for $\$ 1.00$.

Sultan (H)-Also known as Occident. A rapid compact grower, very productive, fruit falls like apples soon as ripe. Fruit large, spherical; dull red with blue bloom; delicious sub-acid, one of the best for cooking; fine keeper and shipper. Will attract attention anywhere by their unusual size and beauty of form and color. Ripens about a week before Burbank.

Wickson-Fruit remarkably handsome, very large, long, heart-shaped, color deep maroon red covered with white bloom; flesh firm. and meaty, yellow, rich and aromatic; cling; pit small. Tree an upright vigorous grower. Excellent keeper and shipper, is being planted largely for market. Early Sept.

Unless noted, 30c; 4 for $\$ 1.00$.

\section{IMPROVED NATIVE PLUMS}

De Soto-Very hardy, extremely productive; medium sized, bright red, good quality. Sept.

Forest Garden-Large, nearly round, purplish red, quality good. Tree vigorous and productive. A favorite variety for both home and market.

Hawkeye-Large, color light mottled red, superior quality, firm; carries well to market. Tree hardy, thrifty, annual bearer. Sept.

Milton-Rather large, dark red, thin skin, flesh firm, good quality. Ripens earlier than Wild Goose. Its large size, good quality and extreme earliness makes it very valuable. A strong grower, productive.

Pottawattamie-A strong, vigorous grower, hardy and an immense bearer; fruit large, yellow ground overspread with pink and white dots. Aug.

Robinson-One of the most profitable market varieties. Very vigorous and productive. Skin, yellow, nearly covered with light red, showy, ripens early.

Weaver-Large, purple, with a blue bloom, very prolific, a constant and regular bearer, and of good quality. Tree very hardy. Aug.
Wild Goose-Fruit medium, red with blue bloom, flesh juicy and sweet. July.

Wolf-Vigorous grower, hardy, very popular. Perfect freestone, immensely productive. Aug.

Wyant-One of the most popular native sorts. Large purplish-red, good quality. Tree a bushy grower, very productive.

$30 c ; 4$ for $\$ 1.00$.

\section{APRICOTS}

Farly Golden-Small, pale orange, juicy and sweet.

Large Early Montgamet-Fruit large, round, early, deep yellow with a fine blush; flesh yellow, firm, juicy and excellent. Tree hardy, a good grower.

Moorpark-Yellow with red cheek, juicy, sweet and rich, freestone, very productive.

Royal-Large, yellow, juicy, rich and delicious; a very fine variety.

$$
30 \mathrm{c} ; 4 \text { for } \$ 1.00 \text {. }
$$

\section{RUSSIAN APRICOTS}

These are quite distinct from the European varieties, hardier, and will produce fruit when other apricots fail. Recommended where peaches cannot be grown. They are all early bearers and productive.

Alexander, Alexis and J. L. Budd.

Superb-A hardy seedling from Kansas. The best flavored, most productive, hardy apricot yet produced. Quality is exquisite. Medium size, light salmon color.

\section{$30 \mathrm{c} ; 4$ for $\$ 1.00$.}

\section{NECTARINES}

Early Violet-Medium size; yellowish green, with a purple cheek; flesh pale green, melting, rich, and high flavored; freestone. Last of August.

Elruge-Medium size; greenish yellow, with a dark red cheek; flesh greenish white, juicy, and high flavored; excellent. Beginning of September.

\section{$30 \mathrm{c} ; 4$ for $\$ 1.00$.}

\section{PEACHES}

Our list comprises a careful selection of the best varieties, covering the whole season. For complete list and fuller description see Catalogue No. 1.

Admiral Dewey - Ripens with the Triumph; better form and color, hardy and productive; the earliest and best yellow freestone. July.

Alexander-Medium, greenish, white, nearly covered with rich red; melting, juicy, sweet. July.

Banner-Tree a good grower, exceedingly hardy in both wood and bud, bears young, is very productive. Fruit large, deep yellow with erimson cheek; flesh yellow, excellent quality, rich, firm; equal to any as a keeper and shipper. A profitable late market variety. Late Sept.

Barnards-Medium, yellow, juicy and rich. Hardy and productive. Early Sept.

Beers' Smock - A large, yellow flesh peach, an improvement on Smock's Free, which it resembles. Ripens a few days later and is a better annual bearer. One of the most desirable and profitable market sorts. Last of Sept.

Belle (Belle of Georgia)-Very large; skin white with red cheek; flesh white, firm and of excellent flavor. Tree a rapid grower, very prolific; fine shipper. Ripens with Crawford's Early.

Carman-Large, resembles Elberta in shape; color, creamy white or pale yellow with deep blush; skin very tough, flesh tender, fine flavor and quite juicy. Ripens wtih Early Rịvers. 
Captain Ede-A landsome, large vellow peach of excellent quality, said to be all improved Flberta, ripening 10 days earliel. A good shipper. Early September.

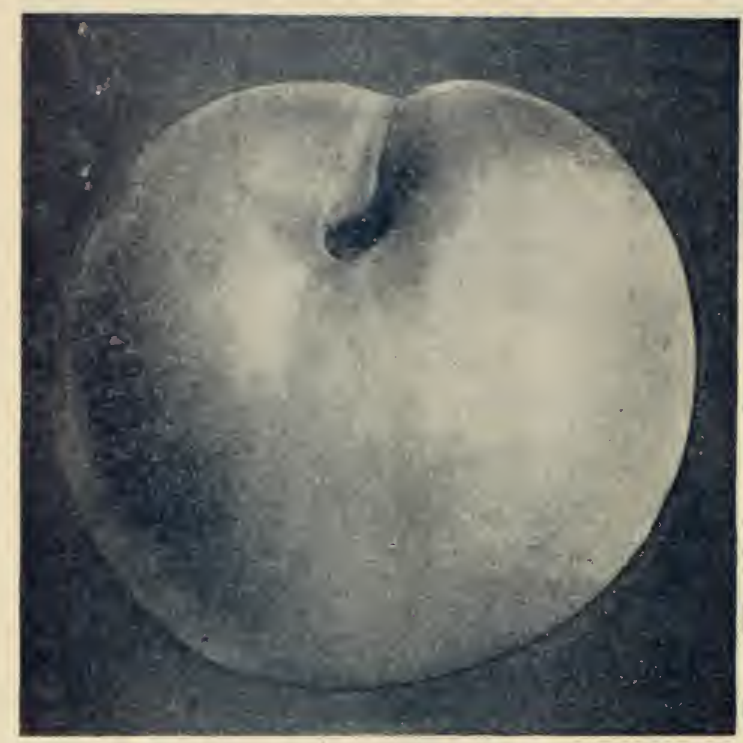

CHAMPION.

Champion-A large, handsome early variety, creamy white with red cheek, sweet, ricll and juicy. Hardy and prosluctive. Aug.

Chair's Choice-Deep yellow with red cheek; firm; few days carlier than Smock. Sept.

Chinese Cling-I - arge, white, shaded red, fine quality. A favorite variety in the south. Aug.

Crawford's Early-A magnificent large yellow peach of good quality. Early in Sept.

Crawford's Late-A superb, large yellow peach. One of the best. Late Sept.

Crosby-One of the hardiest, abundant bearer; medium size, bright yellow, fine quality. Niddle Sept.

Early Rivers-Large, creamy white, with pink eheek, juicy and melting. Aug.

Elberta-Large, yellow, with red cheek; flesh yellow. firm, juicy, of high quality. Exceedingly prolific, sure bearer and hardy. The leading market variety. Follows Early Crawford.

Engle's Mammoth - Large, yellow; resembles Late Crawford but more productive. Sept.

Fitzgerald-Fruit large; brilliant color, bright vellow, suffused with red; flesh deep yellow, best quality. Early Sept.

Foster-Large, deep orange red, flesh yellow; very riclı and juicy. Last of Aug.

Globe-Iarge, flesh firm, juicy, yellow; quality goorl, pleasant, rich, rinous and luscious. Oct.

Gold Drop-Medium size, harby, very proluctive, good quality, early bearer. Last Sept.

Greensboro-The largest and most beautifully colored of all the eally varieties. Double the size of Alexander, ripening at tho sann time. l'lesh white, juicy, and good. July.

Heath Cling-Tery large, flesh white, juicy and melt ing. Good keeper and shipper. Oct.

Hill's Chili-Medium, dull yellow. Extra hardy and productive. Iate Sept.

Horton's Rivers - A magnificent rariety resemlling Early Rivers in every way, but is a perfect free stone, ripens a few days later. Aug.
Kalamazoo-A leading market sort. Large, vellow, fine quality. Extra productive and profitable. Farly Sept.

Lemon Cling-Large, pale yellow, dark red cheek; hardy and productive. Sept.

Lemon Free-Iemon-shaped and color, large size, inmensely productive, excellent quality. Sept.

Lewis-Earliest white freestone. Remarkably harly and productive. August.

Marshall's-Large, yellow, immensely productive. Oct.

Matthew's Beauty-Skin golden yellow, streakerl witl red; flesh yellow, firm, of excellent quality, equal to Elberta in market qualities; ripens later.

Mayflower-Unlike Sneed and the other early varieties it is a RED peach, absolutely red all over, even before it gets ripe enough to ship. Carries to market in fine shape and sells well, as it is the only early peach that is well colored. A strong thrifty grower inclined to overbear, should always be thinned.

Mountain Rose-Large, red, flesh white, juicy, excellent, one of the best. Aug.

Niagara - A very large yellow peacl, originated in Western New York, where it has been well tested and said to be the best orchard variety for that section, surpassing both Elberta and Crawford in size, color, quality and vigor; ripens between Crawford and Elberta.

old Mixon Cling-Large, yellow with red cheek, juicy, high quality. Late Sept.

Old Mixon Free-Large, pale yellow, deep red cheek, white flesh, tender, rich, good. Sept.

Prolific - Large, attractive, firm; flesh yellow, fine flavor, hardy and productive. Sept.

Reeves-Large, yellow, with red cheek; juicr, melting. A good hardy sort. Sept.

Salway - Large, creamy yellow, crimson red cheek, flesh deep yellow, juicy, rich, sweet. Oct.

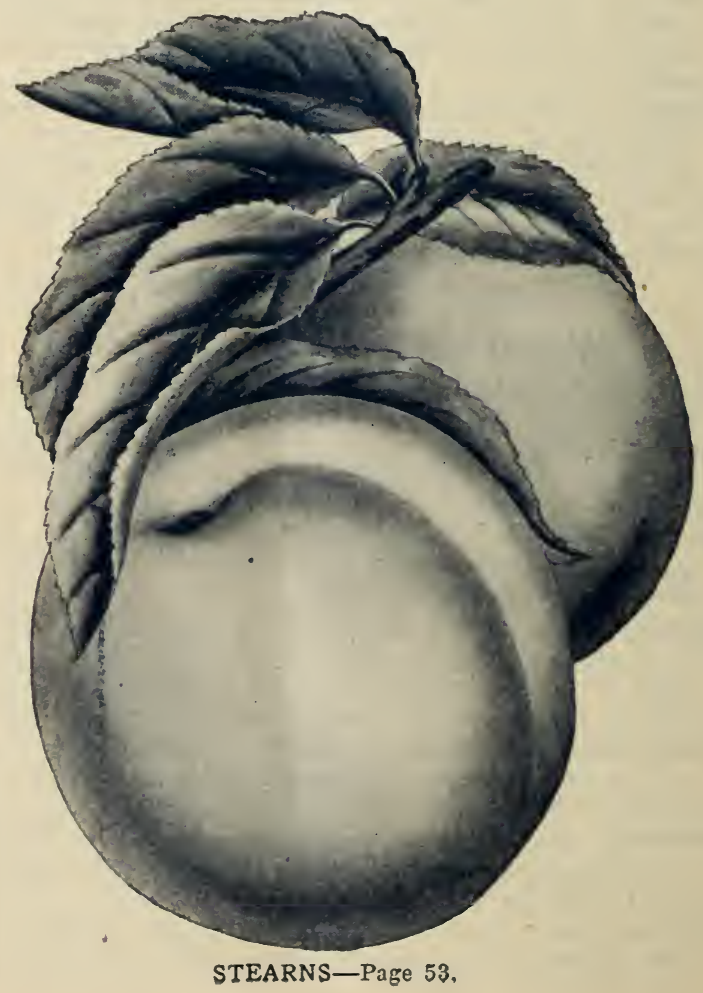


Smock Cling-Large, yellow, juicy, sub-acid. Sept.

Smock Free-Large, yellow and red, bright yellow flesh. Valuable for market. Late Sept.

Sneed-Medium, white, excellent quality, productive. The earliest variety after Mayflower. July.

Snow's Orange-Medium, yellow, melting and juicy. Hardy and productive. Sept.

Stearns-A new Michigan Peach which originated in South Haven, Michigan, and has been a most prolific grower. A perfect freestone, with yellow flesh and brilliant red skin. As a shipper it cannot be surpassed. Tree is a strong, upright grower, extremely hardy and free from disease. Considered by the introducer as the best market Peach grown. July.

Stephens-Resembles an enlarged, high colored old Mixon. Hardy, exceedingly productive. Late Sept.

Stump the World.-Very large white, with a bright red Cheek. End of Sept.

Triumph-Ripens with Alexander, blooms late, sure and abundant bearer; strong, vigorous grower. Fruit good size, yellow with red and crimson cheek.

Wager-Medium, yellow, good quality. Tree hardy, healthy, long-lived, productive. Early Sept.

Wheatland-Large, golden yellow; flesh yellow, juicy, sweet and of fine quality. Sept.

Williams' Favorite-Large, handsome, hardy, very productive. Excellent shipper. One of the most profitable clingstones. Middle Sept.

Wonderful-A fine late market variety similar to Beer's Smock. Late Sept.

Yellow St. John-Nearly as large as Crawford, fully equal in color. Fruit round, brilliant, showy; one of the earliest yellow peaches. Aug.

Unless noted, 15c each; 8 for $\$ 1.00$.

See Price List for larger trees by freight.

\section{MULBERRIES}

New American-Equal to Downing's in all respects and a much hardier tree. Vigorous grower, very productive; the best variety for fruit; ripe from middle June to middle September. 35c; 3 for $\$ 1.00$.

Black or English-Fruit one and one-half inches long, black, and of good flavor. $10 \mathrm{c} ; \$ 1.00$ for $25 \mathrm{c} ; \$ 2.50$ for 100 .

Downing Everbearing-Very large, black, handsome, sweet, rich and excellent. $35 \mathrm{c} ; 3$ for $\$ 1.00$.

Russian-Very harỏy, vigorous grower; valuable for feeding silk worms, etc. Fruit of small size, varies in color from white to black. $10 \mathrm{c} ; \$ 1.00$ for 25 ; $\$ 2.50$ for 100 .

White (Morus Alba)-The common variety. Talued for feeding silk worms. $10 \mathrm{c} ; \$ 1.00$ for $25 ; \$ 2.50$ for 100.

\section{QUINCES}

Angers-A free bearer of good sized fruit, which keeps well, but not equal in quality to the following sorts. 25 c; $\$ 1.00$ for 5 .

Bourgeat-A new golden prolific variety of the best quality. Tree a remarkably strong grower, surpassing all others, yielding immense crops, fruiting at 3 and 4 years in nursery rows. Fruit of largest size, round, rich golden color; smooth, very tender when cooked; has been kept until February in good condition, $30 \mathrm{c} ; 4$ for $\$ 1.00$.

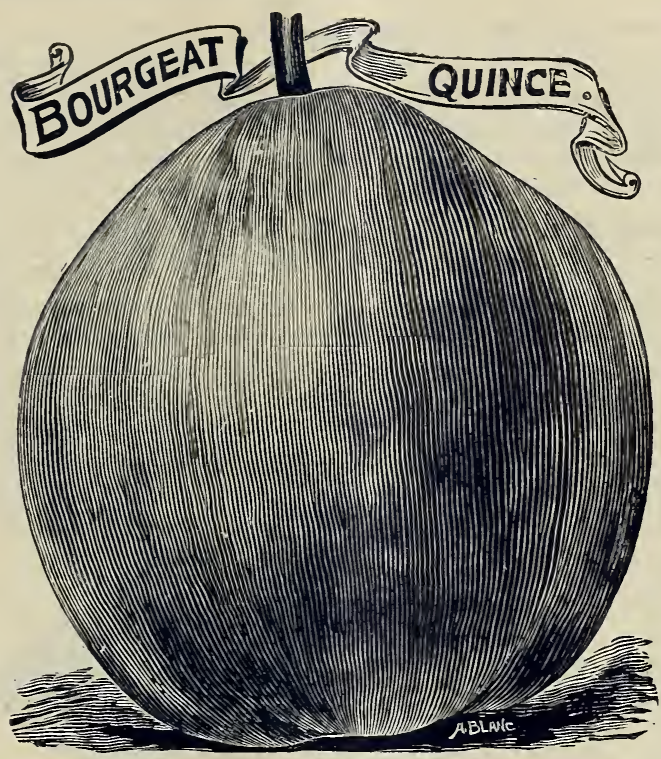

Champion-A prolific and constant bearer, fruit averaging larger than the Orange, more oval in shape, quality equally fine, and a long keeper; bears extremely young. Ripens late. $30 \mathrm{c} ; 4$ for $\$ 1.00$.

Meech-A vigorous grower and immensely productive. The fruit is large, lively orange yellow, of great beauty and delightful fragrance; its cooking qualities are unsurpassed. 35̄e; 3 for $\$ 1.00$.

Orange-Fruit large, bright yellow, of excellent flavor. $35 \mathrm{c} ; 3$ for $\$ 1.00$.

Rea-A seedling of the Orange, averaging much larger, of the same form and color; productive. $35 \mathrm{c} ; \$ 1.00$ for 3 .

\section{NUTS}

Almonds-Soft shell. 25̃e.

Butternut, or White Walnut-A fine native tree producing a large longish nut, which is prized for its sweet, oily, nutritious kernel. $15 \mathrm{c} ; \$ 1.00$ for 8 .

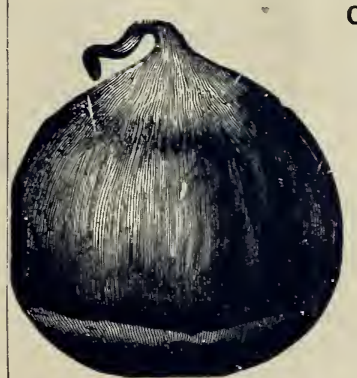

AMERICAN CHESTNUT.
Chestnut, American Sweet-A valuable native tree, both useful and ornamental; timber is very durable, and possesses a fine grain for oil finish. Nuts sweet, of delicate flavor, and are a valuable article of commerce. No farm should be without its grove of nutbearing trees, and the chestnut should be foremost wherever the soil is adapted to its growth. $10 \mathrm{c} ; 40 \mathrm{c}$ for $10 ; \$ 2.00$ for 100 .

Chestnut, Japan-Very distinct from all other chestnuts, dwarf grower, productive, usually producing nuts when two or three vears old. Nuts of immense size, far surpassing all other kinds; of fair quality when outside ski ${ }^{-}$is removed. 25c; 5 for $\$ 1.00$.

Chestnut, Spanish-A handsome round-headed tree producing abundantly very large nuts that find a ready market at good prices; $\$ 25.00$ have been realized at one fruiting from nuts of a single tree. Not as sweet as the American and tree not as hardy. 20c; 6 for $\$ 1.00$. 
Filbert, English-Of easiest culture, growing 6 to 8 feet high, entirely hardy, and one of the most profitable and satisfactory nuts to grow, succeeding on almost all soils, bearing early and abundantly nuts, nearly round, rich and of excellent flavor, admired by all for the dessert. 20e; 6 for $\$ 1.00$.

Filbert, Kentish $\mathrm{Cobb}$-One of the best; large size, oblong, of excellent quality. 25c; $\$ 1.00$ for 5 .

Hickory, Shell Bark-To our taste no other nut that grows, either foreign or native, is superior to this in quality; it possesses a peculiar, ricli nutty flaror excelled by none. The tree is of sturdy, lofty growth. The wood, on account of its great strength and elasticity, is highly prized for making agricultural implements, and is unsurpassed for fuel. 15c; $\$ 1.00$ for 8 .

Pecan-Not hardy in the North; one of the best and most profitable where it succeeds. Makes a very large, tall tree, producing its thin shelled delicious nuts in profusion. 20c; $\$ 1.00$ for 6 .

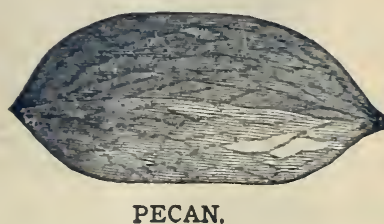

Walnut, French, English or Madeira Nut-A fine, lofty growing tree, with handsome spreading head. Where hardy it produces immense crops of thin-shelled delicious nuts, which are always in demand at good prices; fruit in green state is highly esteemed for pickling. In California and the South large orchards have been planted that are yielding immense profits. Not hardy enough for general culture in the North. $25 \mathrm{c} ; \$ 1.00$ for 5 .

Walnut, Black-A native tree of large size and majestic form, beautiful foliage. The most valuable of all trees for its timber, which enters largely into the manufacture of fine furniture and cabinet ware, and

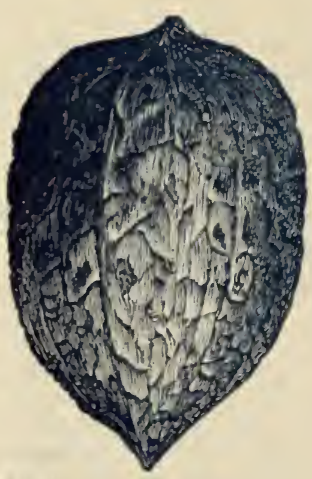
brings the highest price in market. Tree a rapid grower, producing a large round nut of excellent quality. $15 \mathrm{c} ; \$ 1.00$ for 10 .

Walnut, Japan Sieboldi-Perfectly hardy, rapid grower, handsome form, immense leaves; bears young and abundantly, one of the finest ornamental trees. Nuts produced in clusters; resembles Butternut in shape and quality; smaller with smooth and thinner shell. Worthy of extensive planting. 20c; 6 for $\$ 1.00$.

SIEBOLDI.

Walnut, Japan, Max Cor. diformis-Differs from Sieboldi in form of nuts, which are broadpointed, flattened, resembling so me what shell-bark Hickory. 20c; 6 for $\$ 1.00$.

\section{GRAPES}

There is scarcely a yard so small, either in country or city, that room for one to a dozen or more grapevines cannot be found. They do admirably trained up to the side of any building, or along the garden fences, occupying but little room and furnishing an abundance of the most healthful of fruit. Make the soil mellow, and plant the vines somewhat deeper than they stood in the nursery. Plant about eight feet apart, by the fence or building. For vineyard, make rows eight feet apart, six to ten feet in rows.

See price list for larger quantities by freight or express. A heavy stock of splendidly rooted, first-class vines on hand. Write for special prices on large lots.

\section{BLACK}

Campbell's Early-Strong grower, with large, healthy foliage; productive; its keeping and shipping qualities are equalled by no other early grape. Ripens with Moore's Early, but will keep in sound perfect condition long after that variety is gone. Bunch and berry large, glossy black, with blue bloom, sweet and juicy, seeds few and small, part readily from the pulp. Stands at the head of early black grapes for quality. 1-year, 20c; 6 for $\$ 1.00 ; 2$ years, $30 c ; 4$ for $\$ 1.00$.

Champion (Talman) - Very early. Bunch and berry medium, thick skin, poor quality.

Concord-The well known standard variety, succeeds wherever grapes will grow. 1 year, $10 \mathrm{c} ; 10$ for $75 \mathrm{c}$.

Ives-Bunch medium to large; compact; often shouldered, berries me. dium. $10 \mathrm{e} ; 10$ for $75 \mathrm{c}$.

King-Is as hardy and strong a grower as the Concord, and more prolific; ripening between Worden and Concord. The color is the same, grape and cluster larger and more compact. The pulp is more tender, flavor more sprightly, seeds fewer in number The leaves are large, thick and tough and wood very hard and short-jointed. A valuable acquisition and a worthy offspring of its parent, the Concord. 1 year, $50 \mathrm{c} ; 2$ years, $60 \mathrm{c}$.

Moore's Early - B u n e h large, berry large; round, with heavy blue bloom; hardy.

Worden-A splendid grape of the Concord type; larger, better quality and earlier. Vine vigorous; hardy and productive.

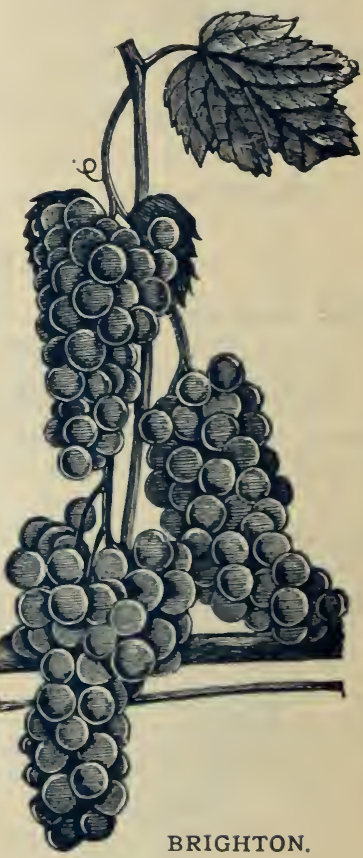

\section{RED OR AMBER}

Agawam (Roger's No. 15)-Berries very large, with thick skin; pulp soft, sweet and sprightly; very vigorous, ripens early.

Brighton-Bunch large, well formed; berries above medium to large; round; excellent flavor and quality; one of the earliest in ripening.

Catawba-Berries large, round; when fully ripe of a dark copper color, with sweet, rich, musky flavor. Requires a long season to arrive at full maturity. 
Delaware-Bunches small, compact, shouldered; berries rather small; round; skin thin. light red; flesh very juicy, sweet, spicy and delicious.

Lindley (Roger's No. 9)-Berries medium to large; flesh tender, sweet and aromatic; ripens early.

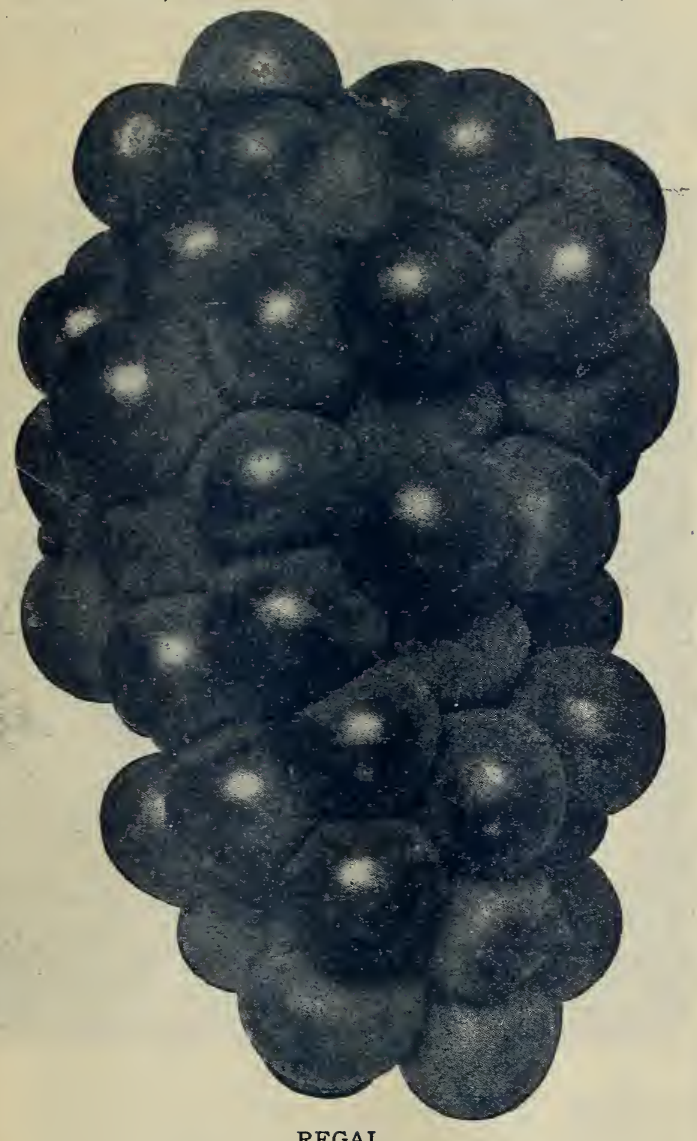

Regal-One of the hardiest red grapes known, it having endured $30^{\circ}$ below zero without injury. It is also one of the most productive and ripens a heavy load of fruit each year. The cluster is of a very desirable size-medium to large-cylindrical, very compact and handsome. Berries are large, persistent, translucent, dark red, juicy, with a skin thin but tough. The pulp tender-easily freeing its seeds. Te believe the Regal possesses a valuable combination of qualities that eminently fit it to take front rank for either home use or market. Strong one-year, 20c; 6 for $\$ 1.00 ; 2$-year, $30 \mathrm{c} ; 4$ for $\$ 1.00$.

Salem (Roger's No. 53) - A strong, vigorous vine; berries large, Catawaba color; thin skin, free from hard pulp; sweet and sprightly; ripens first of September.

Vergennes-Berries large, hold firmly to the stem; light amber; rich and delicious. Is an excellent late keeper.

Woodruff-A handsome, profitable market sort; vine vigorous, productive; iron-clad constitution. Bunch and berry large, attractive, ripens early; fair quality, long keeper, good shipper. In most sections the best red market grape for main crop.

Wyoming-One of the most beautiful of the red or amber grapes, brighter colored than Delaware, earlier, nearly twice as large; flesh tender, juicy, sweet, with a strong, native aroma. The vine is hardy and healthy, with thick, leathery foliage. The best of the red grapes for early market.

\section{WHITE}

Diamond - The leading early white grape, ripening before Moore's Early. White, with rich yellow tinge; juicy, few seeds, almost free from pulp. excellent quality; above medium size, adheres firmly to stem. Vine like Concord in growth, hardiness and foliage. Fine variety for both market and home garden.

Elvira - Vigorous, healthy grower, very productive; bunch and berries medium size. A good wine grape. Ripens with Catawba.

Green Mountain (Winchell)-An extra early variety from Vermont. Skin thin, pulp tender and sweet quality superb. Bunch and berry medium size. Vine hardy, vigorous and productive. 1 year, $25 \mathrm{c} ; 2$ years, $35 \mathrm{c}$.

Martha-Bunches and berries of medium size. greenish white, with a thin bloom; flesh tender, with very little pulp, juicy, sweet and rich, hardy and produetive. Ripens with Concord.

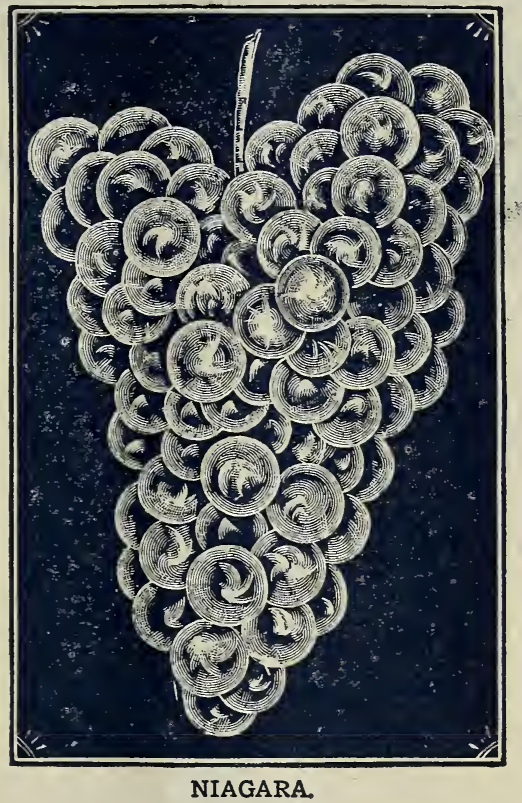

Niagara-Occupies the same position among the white varieties as Concord among the black; the leading profitable market sort. Bunch and berries large, greenish white, changing to pale yellow when fully ripe. Skin thin but tough; quality much like the Concord.

Pocklington-Bunch and berries large, when fully ripe a light golden yellow; juicy, tender, sweet, with little pulp. Vine thoroughly hardy, strong grower, free from mildew; productive. One of the most satisfac. tory white varieties.

Unless noted, 1 year vines, 15c each, or our choice, 10 vines, five sorts, $\$ 1.00$; two-year vines, $25 \mathrm{c}$ each, or our choice, 6 vines, three sorts, $\$ 1.00$.

\section{STRAWBERRIES}

Owing to the unusual and extreme dry weather which has afflicted our locality the past summer, we will not be able to offer Strawberry Plants for this fall's delivery. We expect, however, to have our usual complete assortment and superb stock listed for next spring's sales. 


\section{RASPBERRIES}

Will do well on any soil that will produce a good corn crop. Land should be thoroughly prepared and well enriched; ground bone is one of the best fertilizers. Keep well cultivated and free from weeds and suckers. As soon as they have done bearing, cut out the old wood to give more vigor to the young canes. Plant in rows 5 feet apart, 3 feet apart in rows.

\section{BLACK}

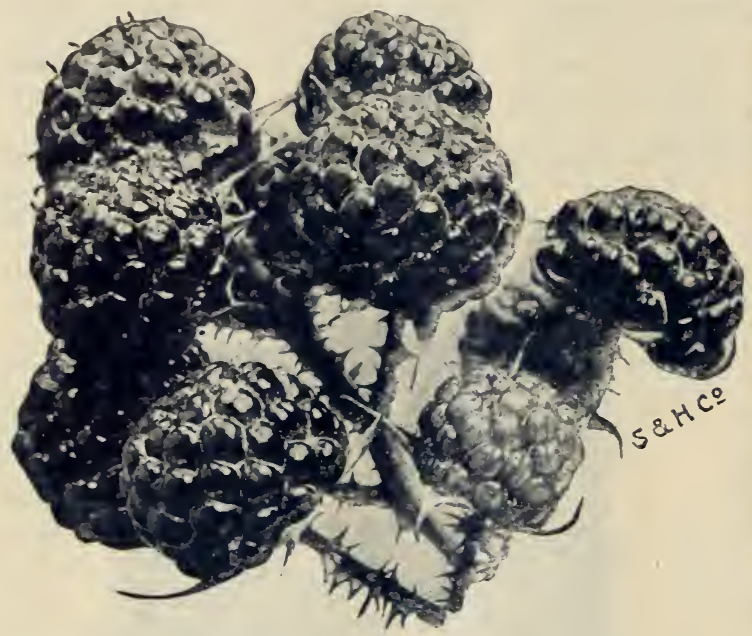

CUMBERLAND.

Cumberland-The largest of all Black-caps. A healthy, vigorous grower, throwing up stout, stocky, well branched canes that produce immense crops of berries. Fruit very large, firm, quality about the same as Gregg, keeps and ships as well as any of the blacks. The inost profitable market variety. Midseason.

Gregg - For many years the leading standard, best known market sort. Very productive, large size, firm, meaty berries, covered with heavy bloom.

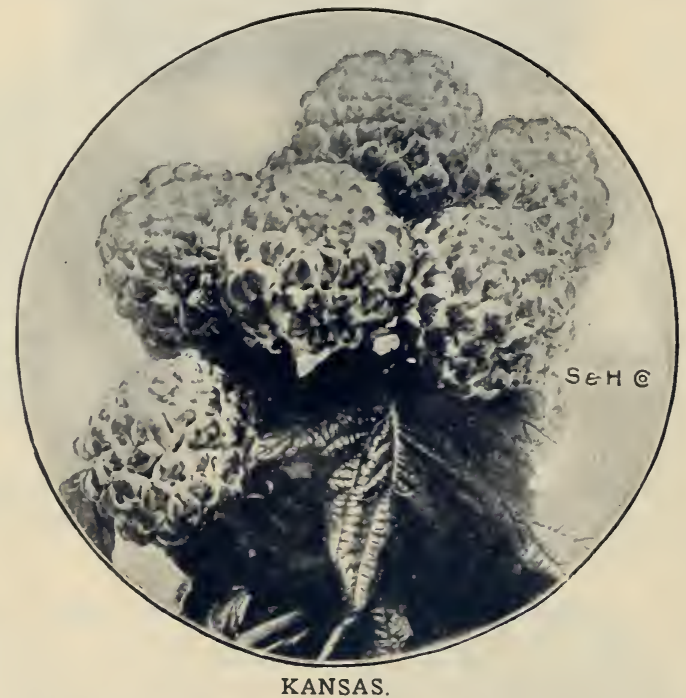

Kansas-Strong, vigorous grower, standing extremes of drought and cold, and bearing immense crops. Early, ripening just after Palmer. Berries size of Gregg, of better color; jet black and almost free from bloom; firm, of best quality; presents a handsome appearance and brings highest price in the market.

\section{YELLOW}

Golden Queen-A beautiful, large golden yellow berry, seedling of the Cuthbert and surpassing that variety in size, beauty, quality and adaptability. ('anes hardy, of strongest growth, productive. Should be in every home garden, its beauty and high quality placing it at the head for table use. 10 for $50 \mathrm{c}$; 100 for $\$ 2.25$.

\section{RED}

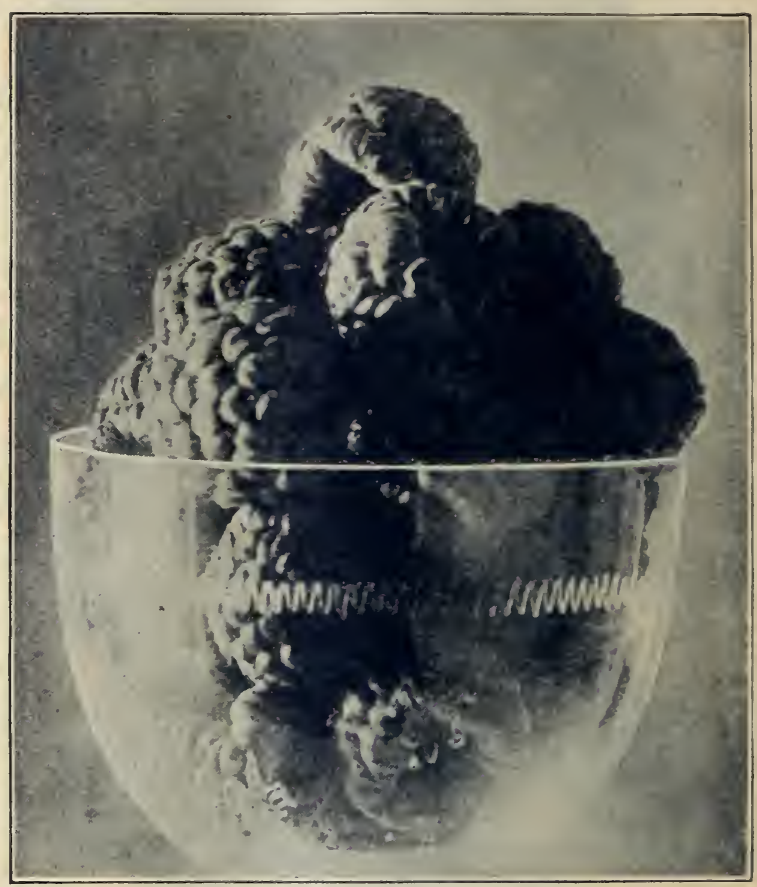

COLUMBIAN

Columbian-Fruit resembles Shaffer's, very large, pur. plish color, rather soft; rich, sprightly flavor, un rivalled for canning, making jam, jell, etc. Bush wonderful for vigor and productiveness, attaining a very large size and producing immense crops.

Cuthbert, or Queen of the Market - A remarkably strong, hardy variety; stands the northern winter and southern summers equal to any. Berries very large, measuring three inches around, conical, rich crimson, very handsome, and so firm they can be shipped hundreds of miles by rail in good condition; flavor is sweet, rich and luscious. The leading market variety for main erop.

Haymaker-An Ohio seedling of the Shaffer and Columbian type, fruit a little more acid, and is later than either, prolinging the season. An enormous producer, excelling the Columbian. Improbable as this may seem, the Haynaker has for several seasons in different localities under same conditions produced more fruit, and we offer it as the most producive raspberry on earth, equal to Columbian in all other respects. 10 for $60 \mathrm{e} ; 100$ for $\$ 2.50$.

King - Pronounced the best early red raspberry by many of the leading horticulturists. Plant a strong grower, very hardy and productive. Berry is firm, a good shipper; large size; beautiful bright scarlet color; ripens with the earliest. Prof. W. J. Green, of Ohio Exp. Station, says: "King has proved the best early red raspberry. It is large, bright red, quite firm, and of good quality." $10 \mathrm{e} ; 10$ for $50 \mathrm{c}$; 100 for $\$ 2.00$. 
Marlboro-Large size, light crimson color; good quality and firm. Vigorous and productive. The best, well tested, large early berry for the North.

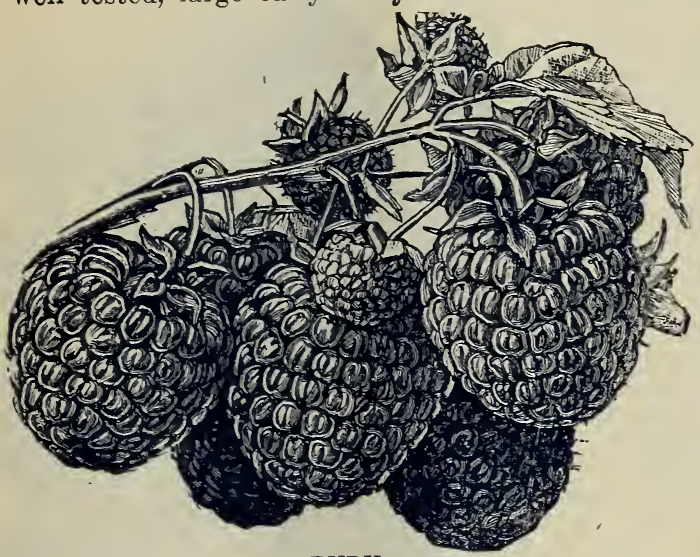

RUBY.

Ruby-Seedling of the Marlboro, originated at Marlboro, N. Y., has fruited for seven years, is shipped daily from there to the Boston market through the season. Ripens with the earliest, continues a long season. Fruit large, bright red, exceedingly firm, excellent quality. Strong grower, large, hardy canes. At Marlboro the most profitable early commercial sort among the bright reds, worthy of trial everywhere. $15 \mathrm{c} ; 10$ for $60 ; 100$ for $\$ 3.00$.

Unless noted, 10c; 10 for $40 \mathrm{c} ; 100$ for $\$ 1.75$.

For prices by freight or express see Price List.

\section{BLACKBERRIES}

Should be planted in rows six to seven feet apart three to five feet in the row. Keep the ground light and rich. Pinch the canes back when they have reached four feet in height.

Ancient Briton-One of the best of the hardy varieties. Very vigorous, healthy and hardy; fruit stems loaded with good-sized berries of tine quality, carry well to and fetch highest price in market. For general planting for homes or market in all section subject to severe winters, the Ancient Briton i recommended as a first-class variety. 10c; 10 for $50 \mathrm{c} ; 100$ for $\$ 3.00$.

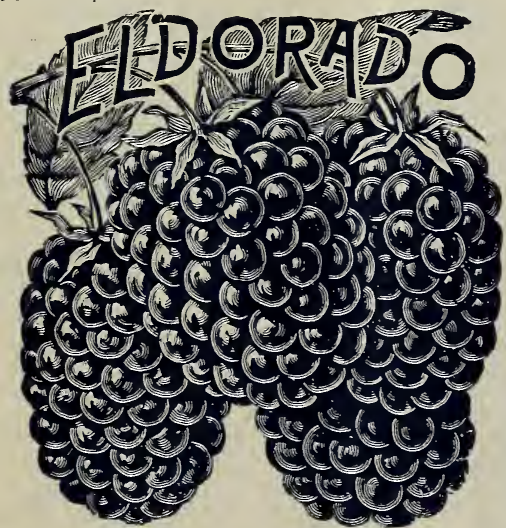

Eldorado-The vines are very vigorous and hardy, enduring the winters of the far northwest without injury, and their yield is enormous. Berries large, jet black; borne in large clusters, and ripen well together; they are very sweet, melting and pleasing to the taste, have no hard core, and keep eight or ten days after picking with quality unimpaired. $10 \mathrm{c} ; 10$ for $60 \mathrm{c} ; 100$ for $\$ 3.00$.

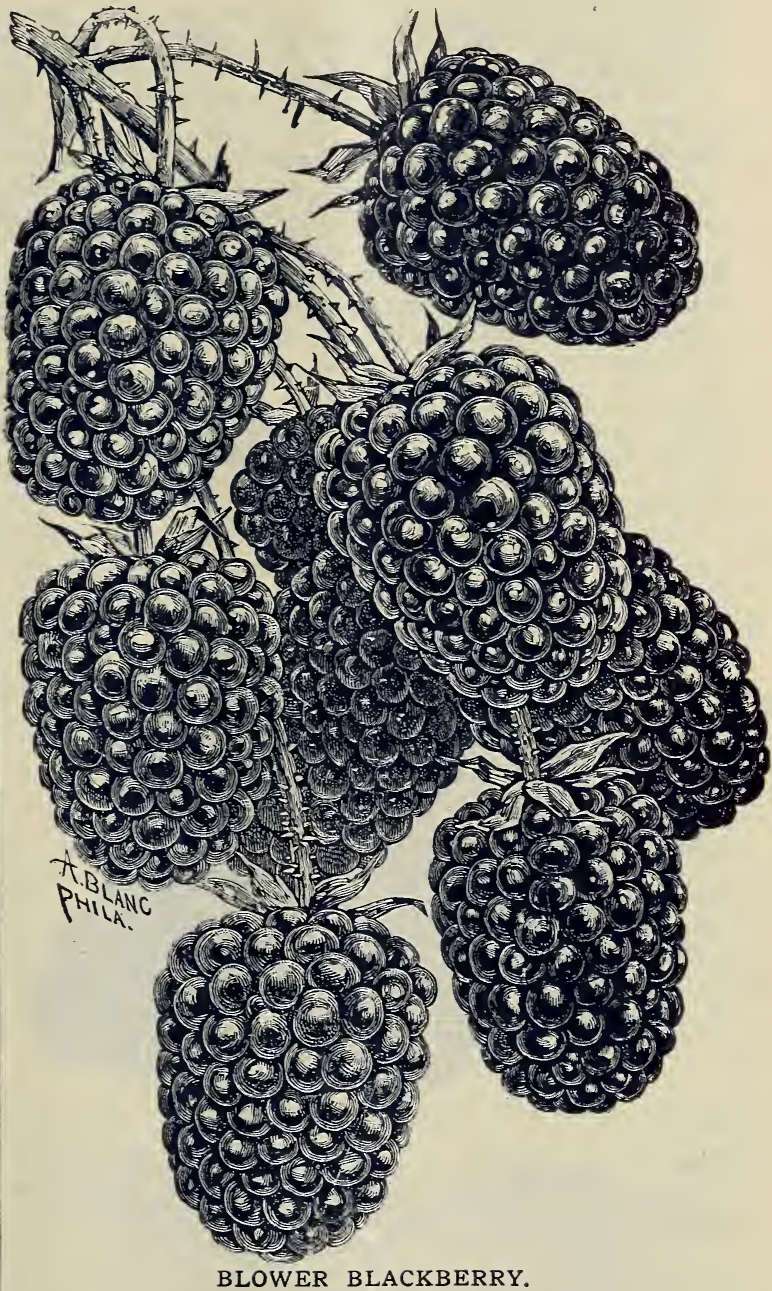

Blower-Originated in the celebrated small fruit belt of Chautauqua County, N. Y., where it has been thoroughly tested for several seasons. Claimed to be the hardiest, most productive, the finest quality, and to bring on the market the highest price of all blackberries. Has produced 2694 berries on one bush, 2720 quarts on 1-3 acre. Large size, jet black, good shipper, best quality, unexcelled productiveness are the main characteristics of this splendid new sort. $10 \mathrm{e} ; 15$ for $\$ 1.00 ; 100$ for $\$ 3.50$.

Early Harvest-Not entirely hardy in the north and needs winter protection. Its earliness, combined with good shippino qualities, make it rery profitable. Compact dwarf grower, enormous bearer. Fruit medium size, black, of excellent quality.

Kittatinny-One of the popular old varieties. Fruit of best quality, large, handsome, ripe as soon as black. Canes erect, strong and vigorous growers, very productive. One of the best for general planting in sections where it is not affected with rust. Midseason.

Mersereau-Remarkably strong grower, upright, producing stout, stocky canes. Claimed to be the hardiest blackberry, standing uninjured 20 degrees below zero without protection. An enormous producer of extra size berries which are brilliant black and retain their color under all conditions; extra quality; sweet, rich and melting, without core. Unsurpassed as a shipper and keeper. Ripens with Snyder. 10 for 50 c; 100 for $\$ 3.00$. 
Ohmer-Five points which recommend this berry: hardy, late, large, productive and of the finest flavor. As large as the largest, as hardy as any good berry; very productive, strong grower, finest quality and late.

Snyder-Extremely hardy, enormously productive, medium size, no hard, sour core; sweet and juicy. The leading variety where hardiness is the consideration. Ripens early.

Taylor-Berries of fine flavor, larger than Snyder. Canes of vigorous growth, iron-clad h rdiness and wonderfully prolific. Ripens late. A fine companion for Snyder in cold sections.

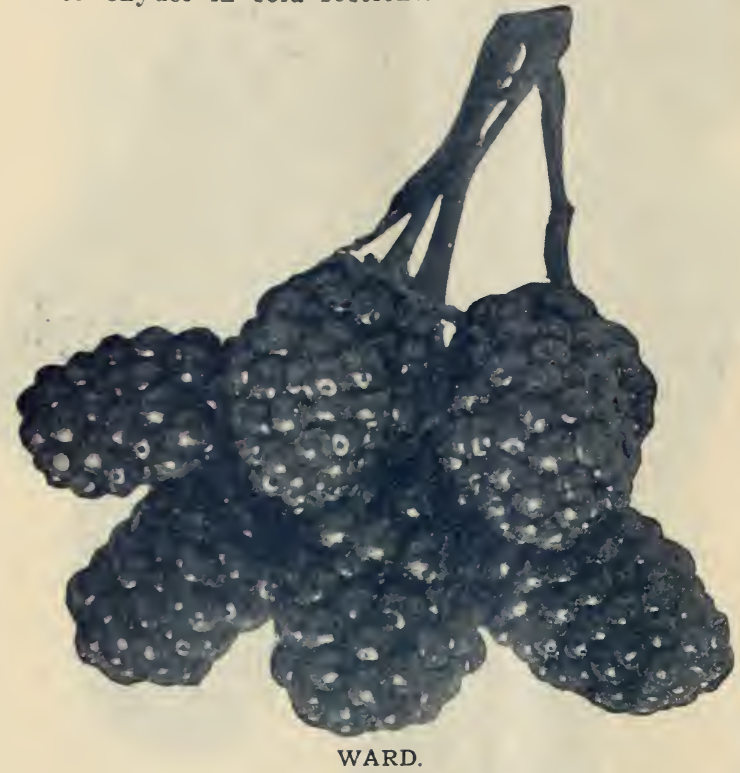

Ward-Undoubtedly a seedling of the Kittatinny, which it resembles, having all of its good qualities and none of its defects. A healthy, strong grower with sturdy canes producing fine large fruit, black throughout, without core, and of excellent quality. Has never suffered from winter injury in New Jersey. An exceedingly prolific sort, the bushes being covered with its fine fruit, producing as many bushels per acre as the Wilson in its prime. $10 \mathrm{c} ; 10$ for $60 \mathrm{c} ; 100$ for $\$ 3.00$.

Wilson-A magnificent, large, very early, beautiful berry of sweet, excellent flavor. Ripens evenly, holds its color well and brings highest market price. Strong grower, exceedingly productive.

Unless noted, $10 \mathrm{c}$ each; $50 \mathrm{c}$ for $10 ; \$ 1.00$ for 30 ; $\$ 2.50$ per 100 .

\section{DEWBERRY}

Lucretia-One of the low-growing trailing blackberries, in size and quality it equals any of the tallgrowing sorts. Perfectly hardy, healthy and remarkably productive, with large, showy flowers. The fruit, which ripens early, is often one and one-half inches long, by one inch in diameter; soft, sweet and luscious throughout, with no hard core; ripe before late raspberries are gone. Should be mulched to keep berries from ground. We can highly recommend this variety. $10 \mathrm{c} ; 25$ for $\$ 1.00 ; 100$ for $\$ 2.00$.

\section{CURRANTS}

Set four feet apart in rich ground; cultivate well or mulch heavily. If the currant worm appears, dust with hellebore; manure freely.

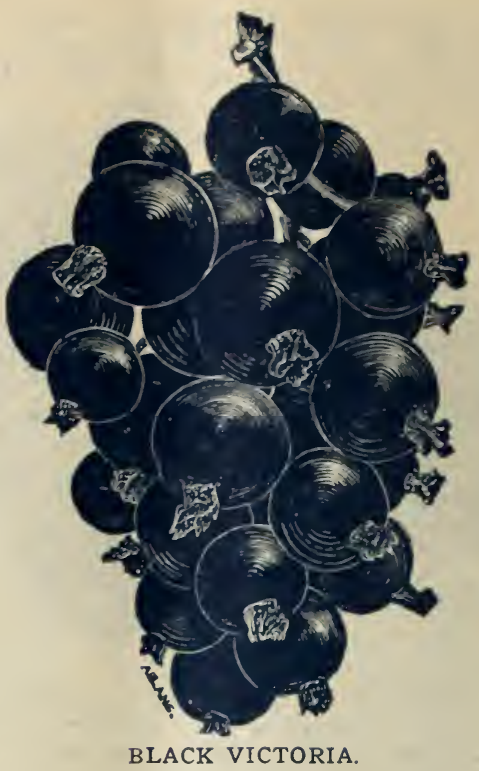

Black Champion-Very productive, large bunch and berry, excellent quality, strong grower.

Black Victoria-A strong, vigorous grower, making a neat bush of unfailing productiveness; fruit of fine flavor and enormous size, the largest black in cultivation.

Cherry-Berries sometimes more than half an inch in diameter, bunches short, vigorous and productive when grown on good soils and well cultivated.

Comet-The bunches are almost approaching grapes in size, being frequently eight inches in length, with from 20 to 26 berries of enormous size and of the most brilliant crimson color. It is likely to become a valuable fruit for dessert purposes, for the juice is particularly refreshing and soft to the palate, it being without acidity. The growth is abnormally vigorous. It will hang a long time in good condition. The first picking has been made as soon as the 10th of June and the last as late as the 22nd of August during three seasons from the same bushes. 15c; 8 for $\$ 1.00$.

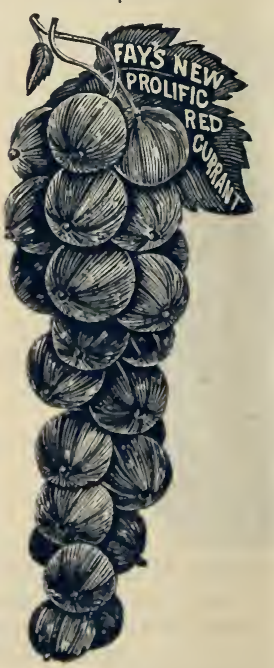

Fay's Prolific-The le a ding market variety. Extra large stems and berries, uniform in size, easily picked, exceedingly productive. No variety ever made as quick a jump into pop. ular favor, the demand most seasons being in excess of the supply.

La Versailles-Very large, red, bunch long, of great beauty and excellent quality; one of the finest and best, and should be in every collection.

London Market-For many years this variety has been fruiting in Michigan where it is now planted extensively and regarded as the best market variety of that great fruit state. Plant is extremely vigorous, with perfect foliage, which it retains through the season, an enormous cropper. Ripens with Victoria, is larger in both bunch and berry, a better bearer. For any use-home garden or market-one of the best. 


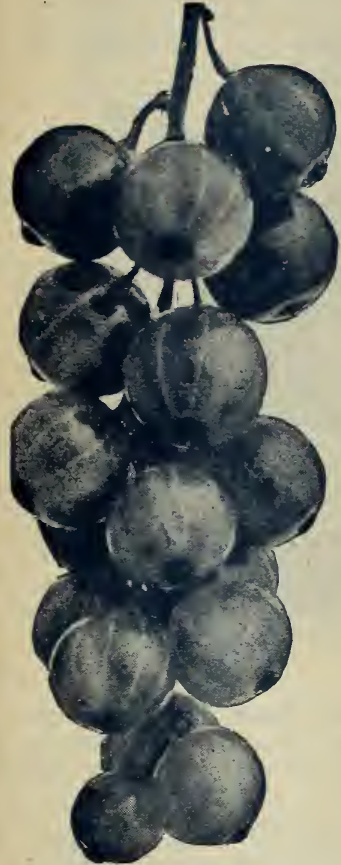

PERFECTION.
Perfection-The only small fruit ever awarded the Gold Medal of the West. ern New York Horticultural Society. A cross between Fay's and White Grape, retaining the valuable characteristics of both parents. Beautiful, bright red, as large or larger than Fay's, holding its size to end of bunch; easy to pick; a great bearer, superior to any other large sort; less acid and of better quality than any other large currant in cultivation. Large, healthy foliage, intermediate in growth between Fay's and White Grape. Kept well cultivated and fertilized they will regularly produce heavy crops of extra size fruit of the very best quality. $30 c ; 4$ for $\$ 1.00$.

Pomona - Medium size, clear bright red, ex cellent quality; hangs long time after ripe; holds up well on market; is one of the best for shipping; easily a $\mathrm{n} d$ cheaply picked. Holds an unparalleled record for actual acreage yield in ordinary field culture.

Red Dutch-An old well-known sort, good quality berry, medium, long bunch. Very productive.

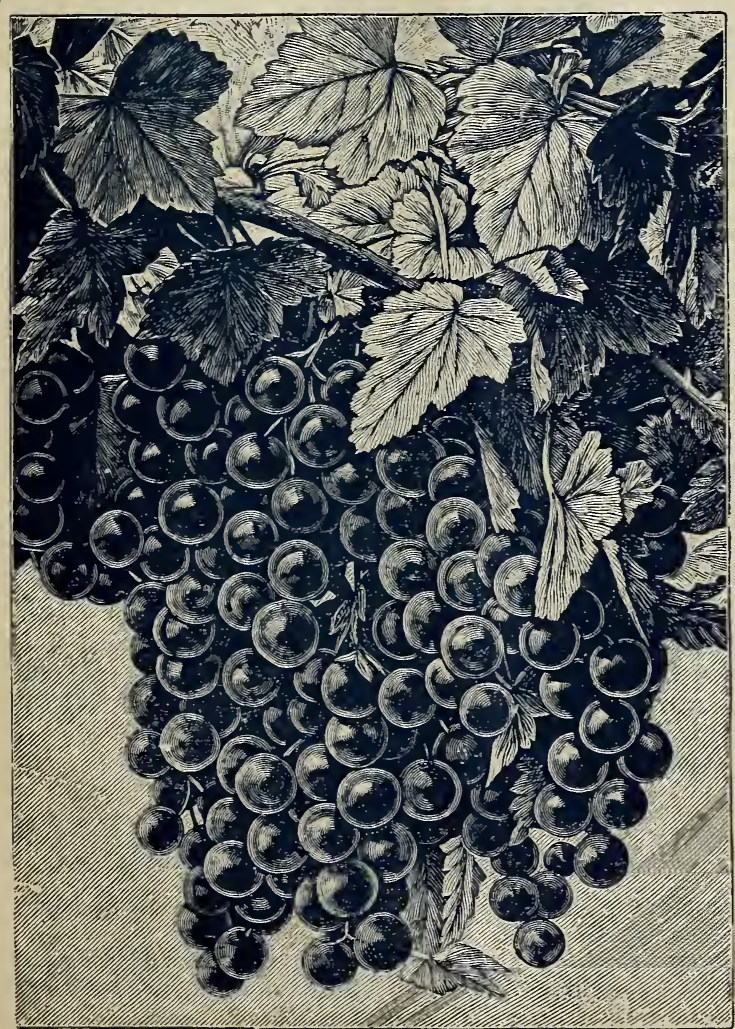

WILDER,
Victoria-Large, bright red; bunches extremely long; berries medium size, of excellent quality. Good erect grower, very productive. Ripens late, making it one of the most valuable sorts.

White Grape-Very large; yellowish white; sweet or very mild; acid, excellent quality and valuable for the table. Productive.

White Imperial - Vigorous grower, very productive. The sweetest and richest white currant extant. Fruit larger and stems longer than White Grape. The fruit sugar and acid are blended without excess of either. The best of all for a dessert fruit. $20 \mathrm{c}$; 6 for $\$ 1.00$.

Wilder-One of the strongest growers and most productive. Bunch and berries very large, bright, attractive red color, even when dead ripe; hangs on bushes in fine condition for handling as late as any known variety. Compared with the celebrated Fays, is equal in size, with longer bunch, better in quality, with much less acidity, ripens at same time, continues on bush much longer, fully as prolific, in some trials largely outyielding it.

Except as noted, one year, 10c each; $\$ 1.00$ for 15; $\$ 5.00$ for 100 .

For prices by freight or express, see Price List.

\section{GOOSEBERRIES}

Plant in good rich soil and give a liberal dressing of manure every season. Regular pruning every year is essential for the production of fine fruit. The English varieties especially do best in partial shade and should be heavily mulched. To prevent mildew spray bushes soon as leaves appear and several times during the summer with pottassium sulphide (liver of sulphur) one ounce to four gallons of water.

\section{ENGLISH VARIETIES}

Crown Bob-Large roundish oval; red, hairy, of first quality.

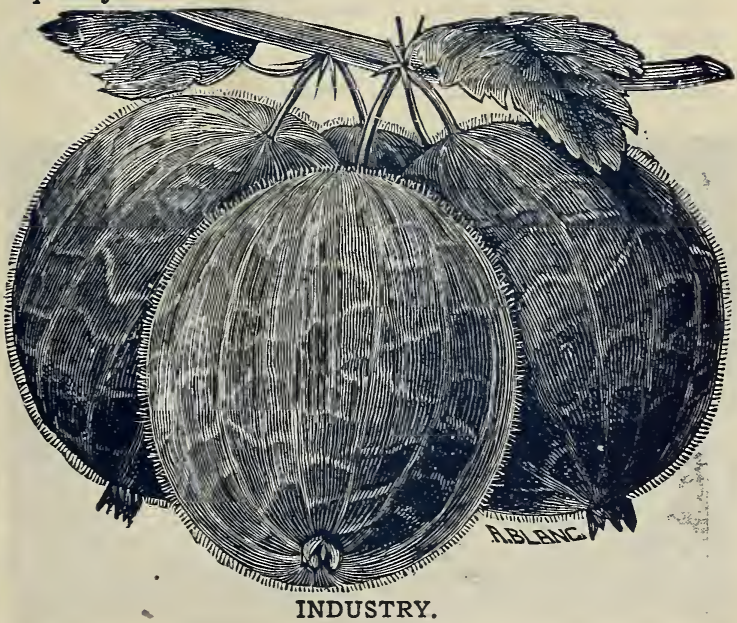

Industry - Berries of largest size, excellent flavor pleasant and rich, dark red color when fully ripe. Strong upright grower, an immense cropper; less, subject to mildew than most of the foreign varieties. the best known and most successful English sort.

Keepsake-Fruit rery large, straw-colored, of excellent flavor; carries well to market. Bloom is well protected by early foliage, making it one of the surest croppers. On our grounds this season, threeyear bushes of Keepsake were loaded with extra large, fine specimens of good quality. Believe it one of the best English sorts for our climate.

Strong plants, 25c each; $\$ 1.00$ for 5 . 


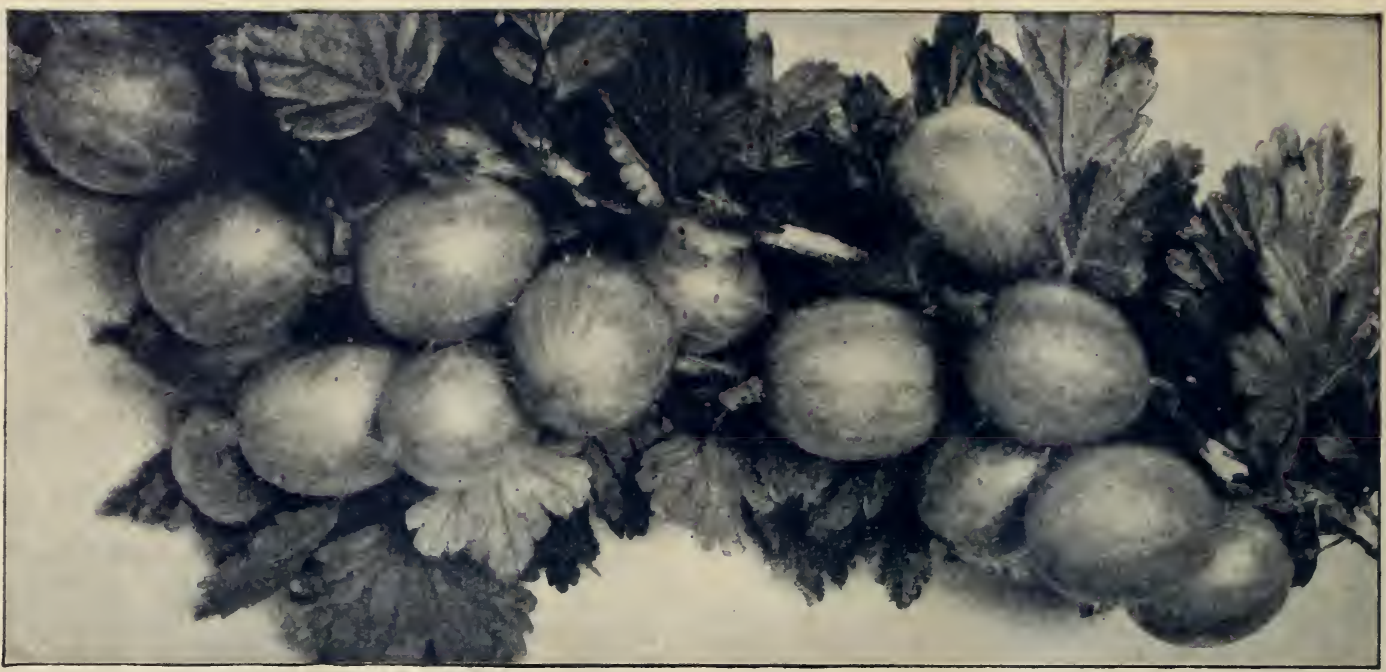

CARMAN GOOSEBERRIES.

\section{A MER I CAN VARIETIES Two Grand New Gooseberries}

CARMAN and PORTAGE

They are both good growers, making fine large plants, producing in profusion their extra large berries of the finest quality. Are similar in habit of growth and productiveness, the Carman averaging a little the largest, more of a golden vellow color when ripe and more oval in shape.

Carman-Our attention was first called to this by Mr. E. S. C'arman, former elitor of the Rural New Yorker, who had it under test in their trial grounds for several year's and who considered it as likely to revolutionize gooseberry culture in this country. Of large size and excellent quality; it sets fruit so closely as usually to require thinning of the berries and propling of the branches.

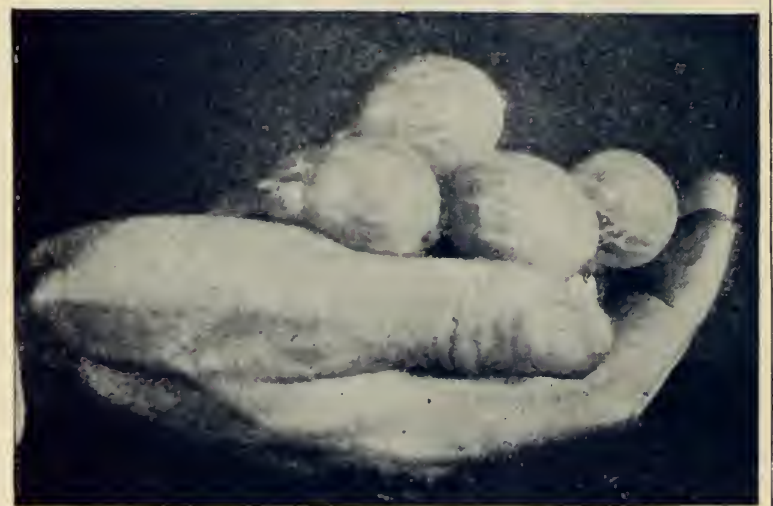

PORTAGE.

Portage-Originated in Ohio, we procuring nearly al the original stock after watehing it a few seasons on originator's grounds. Have tested it on our own grounds for ten years, and it has been grown by originator and friends for a longer period, growing in their favor, in test with many other sorts every season, as the best of all gooseberries.

From E. II. Riehl, the noted small fruit specialist of Illinois: "I'ortage gooseberry is simply marvelous, 'ndoubtedly the best gooseberry I have ever tried.'

Both varieties, $30 \mathrm{c}$ each; 4 for $\$ 1.00$.
Downing-Large, handsome, pale green, and of splendid quality for both cooking and table use; bush a vigorous grower, and usually free from millew. 15c each; $\$ 1.00$ for 8 .

Houghton's - Small to medium; roundish, oval, pale red, sweet, tender, very good; plants spreading; shoots slender, enormously productive. 12c; 10 for $\$ 1.00$.

Josselyn-Large, smooth, prolific and hardy, of best quality. Has been well tested over a wide extent of territory by the side of all the leading varieties, and so far the freest from mildew, both in leaf and fruit, of them all. A wonderful cropper, with bright, clean, healthy foliage. $20 \mathrm{c} ; 6$ for $\$ 1.00$.

Smith's - Large, pale greenish yellow, skin thin, of excellent quality, being unsurpassed by any other variety for table use or cooking; bush moderately vigorous and excessively productive. $15 \mathrm{c} ; \$ 1.00$ for 8 .

\section{ASPARAGUS}

Columbian Mammoth White - A distinct variety of strong, vigorous growth, producing very large, white shoots, that in favorable weather remain white until three or four inches high, or as long as fit for use. Market gardeners and those growing for canners will find this a very profitable variety. 50 for $75 \mathrm{c} ; 100$ for $\$ 1.25$.

Conover's Colossal-A standard variety of large size, tender and excellent quality. 50 for 65 (; 100 for $\$ 1.00$.

Giant Argenteuil-i Fench variety introluced sereral vears ago, is froving the finest and most profitable. Stalks mammotl size, bright attractive color, sweet and tender. It is an immense viclder and very early, makes heds strong enough for profitable cutting before any other variety. 50 for $\$ 1.00$; 100 for $\$ 1.50$.

Palmetto-A very early variety: even, regular si\%e, of excellent quality. 50 for $65 \mathrm{c}$; 100 for $\$ 1.00$.

\section{RHUBARB or PIE PLANT}

Linnaeus-Large, early, tender and fine. The very best of all. $15 \mathrm{c} ; \$ 1.00$ for 8 .

Queen-Strong, vigorous grower, producing extra large stocks of finest quality, of a decided pink color. For canning or cooking in any way its quality is unsurpassed, 15e: \$1.00 for $S$. 


\title{
FRUIT AND ORNAMENTAL TREES
}

\section{GRAPE VINES, SMALL FRUITS, Etc., FOR FALL OF 1911}

\author{
By Express or Freight, Purchaser Paying Charges
}

\section{TWELVE HUNDRED ACRES DEVOTED TO THE NURSERY BUSINESS}

In filling orders from this list we reserve the right, in case we are out of a variety, to substitute another of equal merit when it can be done (always labeling with correct name), unless the party ordering says "no substituting," in which case we will fill the order so far as we can and return the balance. All goods ordered from this list must be sent by express or freight, customers paying charges on receipt of goods. All heavy trees in large amounts should be sent by freight, as charges are so much less, and our perfect packing admits a long journey without injury to the trees. Always give full and explicit shipping directions, as our responsibility ends on delivery of trees in good condition to the freight or express office.

We will be pleased to quote prices to anyone desiring different sizes or stock in larger quantities than offered herein. sending list state definitely the number of each variety and size wanted.

For varieties and descriptions see preceding pages, or for more extended descriptions see Catalogue No. 1. which will be mailed on receipt of $10 \mathrm{cts}$. We guarantee all stock to be up to size and grade specified in list, to be in good condition and carefully packed; this guarantee holds good only when prompt notification on arrival of stock is sent us, stating plainly any errors or cause for complaint.

Our Nurseries have been thoroughly inspected and found free of San Jose scale and other injurious insects and diseases. A certificate of inspection will be attached to all shipments.

TER MS - Net cash with order. No discounts allowed. 5 at 10 rates, 50 at 100 rates; but if remittance amounts to $\$ 25$ and up, everything at lowest rate quoted in this Price List, both fruit and ornamental.

Remember that we employ no agents, are responsible only for orders sent to us through the mail or delivered in person. No charge for packing or delivery at express office or railway station here.

\section{FRUIT DEPARTMENT}

\begin{tabular}{|c|c|c|c|c|c|c|c|}
\hline & Each & Per 10 & Per 100 & & Each & Per 10 & Per 100 \\
\hline to 7 feet....... & $\$ 0 \begin{array}{l}\$ 50 \\
35\end{array}$ & $\begin{array}{rl}\$ 4 & 00 \\
3 & 00\end{array}$ & $\begin{array}{rl}\$ 35 & 00 \\
25 & 00\end{array}$ & 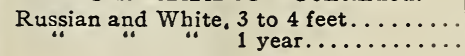 & $\$ \begin{array}{ll}\$ 0 & 20 \\
& 10\end{array}$ & $\$ 1 \begin{array}{l}50 \\
50\end{array}$ & $\$ 15$ \\
\hline $\begin{array}{l}3 \text { to } 4 \text { feet. ..... } \\
\text { Baldwin. Bismar }\end{array}$ & & 200 & 1600 & NUTS. & & & \\
\hline $\begin{array}{l}\text { ing, Staymans, Duchesse, Fameuse, } \\
\text { Jonathan, Maxson's Early, McIntosh, } \\
\text { Northern Spy, Opalescent and Yellow }\end{array}$ & & & & $\begin{array}{l}\text { Almond, soft shell, } 3 \text { to } 4 \text { feet. } \ldots \ldots \ldots \ldots \\
\text { Butternuts, } 4 \text { to } 6 \text { feet. } \ldots \ldots \ldots \ldots \ldots \ldots \ldots\end{array}$ & $\begin{array}{l}35 \\
50 \\
30 \\
50\end{array}$ & $\begin{array}{ll}3 & 00 \\
4 & 00 \\
2 & 50\end{array}$ & \\
\hline $\begin{array}{l}\text { Transparent, } 5 \\
\text { Above, } 4 t\end{array}$ & $\begin{array}{l}60 \\
40\end{array}$ & $\begin{array}{ll}5 & 60 \\
3 & 50\end{array}$ & $\begin{array}{ll}40 & 00 \\
30 & 00\end{array}$ & Chestnut, American Sweet, $5 \mathrm{t}$ & $\begin{array}{l}50 \\
30\end{array}$ & $\begin{array}{l}400 \\
250\end{array}$ & \\
\hline & & 2.50 & 2000 & 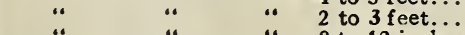 & 20 & 150 & \\
\hline Crab Apples, 5 to & 50 & 400 & 3500 & " $\quad 8$ to & 10 & 50 & \\
\hline pples............ & & $\begin{array}{ll}3 & 00 \\
3 & 50\end{array}$ & $\begin{array}{ll}25 & 00 \\
35 & 00\end{array}$ & Japan, 2 to 3 feet... & $\begin{array}{l}60 \\
50\end{array}$ & $\begin{array}{l}500 \\
40\end{array}$ & 然 \\
\hline PEARS. & & & & “. Spanish, 3 to $4 \mathrm{f}$ & 35 & $\begin{array}{ll}3 & 00 \\
2 & 00\end{array}$ & \\
\hline ard, 5 to $7 \mathrm{f}$ & $\begin{array}{l}50 \\
35\end{array}$ & 400 & 3500 & $\because \quad$ Numbo and Paragon, 2 to $3 \mathrm{ft}$. & 85 & & \\
\hline Seckel, 5 & & 500 & ..... & Ridgley, 2 to 3 feet. ......... & & & \\
\hline Dwarf Pears, 4 to $5 \mathrm{f}$ & $\begin{array}{l}25 \\
20\end{array}$ & $\begin{array}{ll}4 & 00 \\
2 & 00 \\
1 & 50\end{array}$ & $\begin{array}{l}1600 \\
1400\end{array}$ & Filberts, English, 2 to & $\begin{array}{l}99 \\
35 \\
50\end{array}$ & 300 & \\
\hline 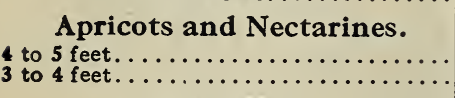 & $\begin{array}{l}40 \\
35\end{array}$ & $\begin{array}{ll}3 & 50 \\
3 & 00\end{array}$ & & $\begin{array}{l}\text { Hickory, } 1 \frac{1}{2} \text { to } 2 \\
\text { Pecans, } 11 / 2 \text { to } 2 \\
\text { Walnut, Black, } 4\end{array}$ & $\begin{array}{l}60 \\
85 \\
50 \\
35\end{array}$ & $\begin{array}{ll}5 & 00 \\
7 & 50 \\
4 & 00 \\
3 & 00\end{array}$ & \\
\hline PEACHES. & & & & ". $\quad$ " $32 t$ & $\begin{array}{l}30 \\
20\end{array}$ & $\begin{array}{l}250 \\
180\end{array}$ & $\begin{array}{l}2000 \\
1500\end{array}$ \\
\hline$\ldots \ldots \ldots \ldots \ldots \ldots$ & & $\begin{array}{ll}2 & 00 \\
1 & 50\end{array}$ & $\begin{array}{l}1500 \\
1000\end{array}$ & “ Japar-Seibold & & 400 & \\
\hline . & 10 & 80 & 00 & 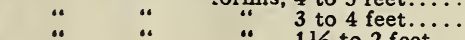 & & & \\
\hline PLUMS. & & & & .. $8 t$ & $\begin{array}{l}20 \\
12\end{array}$ & $\begin{array}{ll}1 & 80 \\
1 & 00\end{array}$ & $\begin{array}{rl}15 & 00 \\
5 & \mathrm{cc}\end{array}$ \\
\hline European and Japan, 5 & 40 & 350 & & English, $11 / 2$ to 2 fee & 35 & 200 & \\
\hline Native, 5 to 7 feet.... & 50 & $\begin{array}{l}250 \\
400\end{array}$ & & & & & \\
\hline $\begin{array}{l}\text { "“ } 4 \text { to } 5 \text { feet...... } \\
\text { Grand Duke. Monarch, } \\
\text { Reine Claude. Shrops } \\
\text { America, Climax, Santa F }\end{array}$ & 40 & 350 & $\cdots$ & 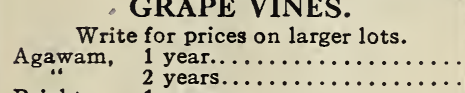 & $\begin{array}{l}10 \\
15\end{array}$ & & \\
\hline & $\begin{array}{l}50 \\
40\end{array}$ & & $\begin{array}{ll}35 & 00 \\
30 & 00\end{array}$ & Brighton, $\quad 1 \mathrm{y}$ & 10 & $\begin{array}{l}60 \\
80\end{array}$ & \\
\hline d Sugar Prune. & & 60 & $\cdots \cdot$ & Campbells' Early, i ye & 15 & 100 & \\
\hline$\cdots$ & & $\begin{array}{lll}5 & 00 \\
3 & 50\end{array}$ & & Catawba, 1 year... 2 ye & $\begin{array}{l}20 \\
10\end{array}$ & & \\
\hline & & & & “1 2 & 15 & 60 & \\
\hline 4 to 5 & 60 & 500 & $\cdots$ & Champion, 1 y & 10 & & \\
\hline ERRIES. & & & & Concord, $1 \mathrm{y}$ & & & \\
\hline$\ldots \ldots \ldots$ & 40 & & & & & 60 & \\
\hline $.5 \mathrm{t}$ & $\begin{array}{l}3 \\
5\end{array}$ & $\begin{array}{l}2 \\
4 \\
c\end{array}$ & & Delaware, ${ }_{2}^{1} \mathrm{y}$ & $\begin{array}{l}10 \\
15\end{array}$ & $\begin{array}{l}60 \\
80\end{array}$ & \\
\hline & & & & Diamond, 1 y & 10 & 60 & \\
\hline 3 to $4 \mathrm{fe}$ & $\begin{array}{l}40 \\
30\end{array}$ & $\begin{array}{ll}3 & 00 \\
2 & 50\end{array}$ & & & 15 & $\begin{array}{l}80 \\
60\end{array}$ & \\
\hline QUINCES. & & & & Emp & $\begin{array}{l}10 \\
10\end{array}$ & $\begin{array}{l}80 \\
60\end{array}$ & 60 \\
\hline 4 to $5 \mathrm{fe}$ & 30 & & & & & & \\
\hline & $\begin{array}{l}25 \\
40\end{array}$ & $\begin{array}{ll}2 & 0 \\
3 & 5\end{array}$ & $\begin{array}{ll}15 & 0 \\
30 & 0\end{array}$ & $\begin{array}{c}\text { Green Mountain, } 1 \text { year... } \\
2 \text { years. }\end{array}$ & $\begin{array}{l}20 \\
25\end{array}$ & $\begin{array}{ll}1 & 50 \\
2 & 00\end{array}$ & $\cdots$ \\
\hline & & 30 & 2500 & Ives, 1 yea & 10 & 60 & \\
\hline Orange, Meech and Rea`s, 4 & 60 & & & & 15 & 80 & \\
\hline $\cos _{2}$ & & & & Lindley, 1 & $\begin{array}{l}50 \\
50 \\
10\end{array}$ & & \\
\hline New American and I & 75 & & & & 15 & 80 & \\
\hline Russian and White, & $\begin{array}{l}60 \\
30\end{array}$ & $\begin{array}{l}500 \\
250\end{array}$ & & & 15 & $\begin{array}{l}60 \\
80\end{array}$ & 50 \\
\hline
\end{tabular}


GRAPE VINES - Continued.

Moore's Early, 1 year.

Niagara, 1 year........ 2 years.

Pocklington, 1 year.

Regal, 1 year.

Salem, 1 year.

". 2 years.

Vergennes, 1 year

Woodruff, 1 year.

Woodruff, 1 year.

Worden, 1 year.

Wyoming, 1 year.

\section{CURRANTS.}

Black Victoria and Champion, 1 year.

Cherry and La Versailles, 1 year. 2 years.

Comet, 1 year.

Fay's Prolific, 1 year

London Market and Pomona, 1 year.

London ." ." Pomona, 2 years.

Perfection, 2 years

Red Dutch, 1 year.

virtoria, 1 year.

$$
2 \text { year }
$$

White Grape, 1 year.

White Imperial, 1 year.

Wilder, 1 year..

\section{GOOSEBERRIES.}

Carman and Portage, 1 year..

Downing, 1 year.

Houghton, 1 year

Whitesmith, Industry and Keepsake.

\section{2 years}

Josselyn, 1 year.

". 2 years

Smith's Improved, 1 year.

\section{RASPBERRIES.}

Cuthbert, Marlboro, Gregg and Kansas

\section{Columbian.}

Cumberland

Eaton

Golden Queen

Haymaker.

King.

Plum Farmer.

\section{BLACKBERRIES}

Snyder, Taylor's Prolific, Kittatinny Early Harvest and Wilson's ........ Ancient Briton.

Blowers.

Eldorado and $\mathbf{W}$ ard

Mersereau

Lucretia Dewberries.

ASPARAGUS.

Conover's Colossal and Palmetto, 1 year. Columbian Mammoth White, 1 year...

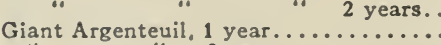
2 years.

RHUBARB.

\section{ORNAMENTAL DEPARTMENT}

\begin{tabular}{|c|c|c|c|}
\hline & Each & Per 10 & Per 100 \\
\hline Ailanthus -6 & $\begin{array}{r}\$ 060 \\
\quad 75\end{array}$ & $\begin{array}{rl}\$ 5 & 00 \\
6 & 50\end{array}$ & \\
\hline Alder-Imperial cut-lea & $\begin{array}{ll}1 & 00 \\
1 & 25\end{array}$ & $\ldots \ldots$ & \\
\hline $\begin{array}{l}\text { European, } 6 \text { to } 8 \text { feet.. } \\
8 \text { to } 10 \text { feet. }\end{array}$ & & & \\
\hline
\end{tabular}

$\begin{array}{ll}5 & 00 \\ 6 & 00\end{array}$

800

$\begin{array}{ll}5 & 00 \\ 6 & 00\end{array}$

600

400

500
1500

400

500

$\begin{array}{ll}4 & 00 \\ 5 & 00\end{array}$

$\begin{array}{lll}5 & 00 \\ 5 & 00\end{array}$

$100 \quad 600$

120

50

$\begin{array}{ll}5 & 00 \\ 6 & 00\end{array}$

1200

800

1000

$\begin{array}{ll}7 & 00 \\ 8 & 00\end{array}$

125
150

150
150

400

200

$\begin{array}{lll}1 & 75 \\ 1 & 75\end{array}$

$\begin{array}{ll}1 & 75 \\ 2 & 00\end{array}$ \begin{tabular}{l|l|l|l|l|} 
DECIDUOUS TREES-Con. & Each & Per 10 & Per 100 \\
\cline { 2 - 4 }
\end{tabular} Amelanchier Botryapium-2 to 3 feet....\$ $25 \$ 200$ Aralia Japonica and Spinosa-4 to 6 feet. $50 \quad 400$

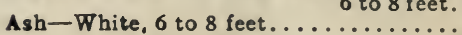
European, 6 to 8 feet.

Flowering, 6 to 8 feet.

" 8 to 10 feet.

Green. 6 to 8 feet.

Globe-headed, 10 feet

Buckeye-4 to 5 feet.

Balm of Gilead -8 to 10 feet

Beech-Purple-leaved, River's Grafted,

.. $\quad 3$ to 4 feet..
4 to 6 feet.

$$
3 \text { to } 4 \text { feet........ }
$$

European, 3 to 4 feet.

Tricolor, 3 to 4 feet.

Fern-leaved, 3 to 4 feet.

Birch-Purple-leaved 4 to 6 feet.......... 190 Scotch, 4 to 6 feet........ 6 to 8 feet.

Canoe, 6 to 8 feet.

$$
8 \text { to } 8 \text { feet. }
$$

Pyramidal, 4 to 6 feet.

Red. 8 to 10 feet.

Bird Cherry 4 to 6 feet.

$$
\text { Catalpa-Speciosa and T }
$$

Catalpa-Speciosa and Tea's Japan.

“ $\quad$ 8 to 10 feet. 6 to 8 feet Bungei-Grafted, 8 to 10 feet. Dwarf, 3 to 4 feet.

Silver-leaved, 4 to 6 feet.

Golden-leaved, 4 to 6 feet........

Cercidiphyllum Japonicum-

4 to 6 feet.

Cherry-Japan Plowering, 4 to 6 feet

Double white, 3 to 4 feet.....

4 to 6 feet...

Rhexi f. pl. 3 to 4 feet.

Cornus Florida-Red Flowered, 2 to $3 \mathrm{ft}$. 3 to $4 \mathrm{ft}$. 1125

.. White flowered, 3 to 4 feet....

" $"$. 4 to 5 feet...

Crab Applo-Bechtel's Double, 3 to $4 \mathrm{ft}$ Parkmani, 3 to 4 feet. 5 ft. Atrosanguinea and Floribunda, 4 to 5 feet.....

Medwietskyana, 3 to 4 feet

Deciduous Cyppress -3 to 4 feet ........ Elm-American, 6 to 8 feet....

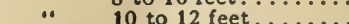

Doveii, 6 to 8 feet.

English 8 to 10 feet.

8 to 10 feet...

8 to 10 feet.

Purple-leaf, 6 to 8 feet.

Scotch, 6 to 8 feet.

$$
8 \text { to } 10 \text { feet. }
$$

- Sel ct'd Specimens, $\$ 3.00$ to $\$ 5.00$ each

Enonymous-European (Strawberry tree)

$$
4 \text { to } 6 \text { feet. }
$$

Hackberry-4 to 6 feet.

Honey Locust-Thornless, 4 to 6 feet.

Horse Chestnut-White-flowering. 4 to $6 \mathrm{ft}$ to 6 feet..... 35 6 to $8 \mathrm{ft} 100$

Double, white-flowering 5 to 6 feet.......... 100

Red-flowered, 4 to $5 \mathrm{ft}$. Dwarf, $11 / 2$ to 2 feet

Judas Troe -5 to 6 feet.

Kentucky Coffee Tree- 6 to 8 feet.

Kolreuteria Paniculata -3 to 4 feet.

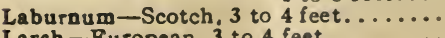

Larch-European, 3 to 4 feet.

Linden-American, 6 to 8 feet.

Buropean, 6 to 8 feet.

$$
8 \text { to } 8 \text { feet... }
$$

$\dddot{\$ 3} \dot{0} 00$

4000

$6 \%$

750

$\begin{array}{ll}4 & 00 \\ 5 & 00\end{array}$

$3 \dot{3} 00$

4000

$\begin{array}{ll}3 & 50 \\ 4 & 00\end{array}$

400

$\begin{array}{lll}4 & 00 \\ 5 & 00\end{array}$

$\because 30$

900

600

$\begin{array}{ll}8 & 00 \\ 5 & 00\end{array}$

600

$\begin{array}{ll}7 & 50\end{array}$

$\begin{array}{ll}6 & 00 \\ 7 & 50\end{array}$

$750 \ldots \ldots$

$\ldots \ldots \ldots$

$350 \cdots \cdots$

400

$350 \quad 3000$

$\begin{array}{lllll}5 & 00 & 40 & 00\end{array}$

10
8 25

$7 \quad 50$

..............

...........

600

400

$\begin{array}{ll}5 & 00 \\ 5 & 00\end{array}$

850

1000

450

250

600

750

600

600

750

600

750

$\begin{array}{ll}8 & 50 \\ 7 & 50\end{array}$

$\begin{array}{ll}7 & 50 \\ 8 & 50\end{array}$

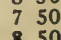

850

$\begin{array}{ll}7 & 50 \\ 8 & 50\end{array}$

750

85

$\begin{array}{ll}5 & 00 \\ 6 & 00\end{array}$

$\begin{array}{ll}6 & 00 \\ 7 & 50\end{array}$

4500

5000

300

350

400

$\begin{array}{ll}3 & 00 \\ 6 & 50\end{array}$

850

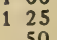


PRICE LISTS OF TREES, ETC.

DECIDUOUS TREES-Con.

Linden-Gold-twig, 6 to 8 feet. .......\$0 85 Liquidamber -6 to 8 feet. Magnclia-Acuminata, 4 to 6 feet. Soulangeana, 2 to 3 feet. 3 to 4 feet.

Halliana, 2 to 3 feet... Speciosa, 2 to 3 feet.

Glauca, 2 to ? feet..

Purpurea, 2 to 3 feet.

Heavy transplanted with bail of earth, assorted, 4 to $5 \mathrm{ft}$.

M. plo-Ash-leaved, 6 to 8 feet. 8 to 10 feet.

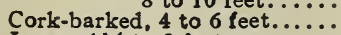

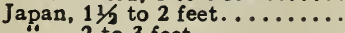

Norway. 6 to 3 feet.

$$
8 \text { to } 10 \text { feet. }
$$

Reitenb 10 to 12 feet...

.. 6 to 8 feet..........

Scarlet, 6 to 8 feet

Schwedleri, 6 to 8 feet.

Silver-leaved, 6 to 8 feet. 8 to 10 feet.

Sugar or Rock, 6 to 8 feet.

Sycamore, 6 to 10 feet... 8 to 8 feet. 10 feet.

Purple-leaved, 6 to $8 \mathrm{ft}$.

Tartarian, 4 to 6 feet.

Ginnala, 3 to 4 teet

Wier's Cut-leaved, 6 to 8 feet.

Mountain Ash-European, 6 to 8 feet. $\therefore$ Oak-leaved, 4 to 6 feet.

Oaks-Bur or Mossy Cup, and European or Royal, 6 to 8 feet.

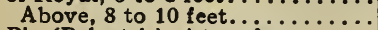

$\because \quad$ Pin (Palustris), 4 to o feet.

.. $\quad$. 8 to 8 feet.......

Red, 8 to 10 feet.............. Scarlet, 4 to 6 feet.

Turkey, 4 to 6 feet.

White, 4 to 6 feet.

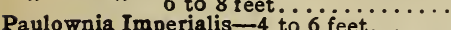

Peach - Flowering Red \& White, 3 to $4 \mathrm{ft}$

Persimmon-American, 4 to 6 feet.

Poplar-Carolina and Lombardy, 6 to $8 \mathrm{ft}$ 8 to $10 \mathrm{ft}$

Aurea (Golden), 6 to 8 feet. 10 to $12 \mathrm{ft}$.

Bolleana (Silver Leaf), 6 to $8 \mathrm{ft}$

Ptelia Trifoliata -4 to 6 feet. 8 to $10 \mathrm{ft}$

Ptelia Trifoliata-4 to 6 feet.. 3 Gold-leaved, 3 to 4 feet Russian Olive -3 to 4 feet...................

Salisburia-Maiden Hair, 6 to 8 feet...

Sophora Japonica-2 to 3 feet.

Sycamore-European, 6 to 8 feet. 8 to 10 feet.

American, 6 to 8 feet.

Thorn's-Double White, Pink and Paul's Scarlet, 3 to 4 feet.

Same, 4 to 6 feet...
Crus-Galli, 4 to 6 feet.

Tulip Treo-6 to 8 feet.

Virgilia Lutea -4 to 6 feet.

" 8 to 10 feet.

Gold-bark, 6 to 8 feet.

Laurel-leaved, 6 to 8 feet.

Royal, Silver-leaf, 6 to 8 feet.

Scarlet, 6 to 8 feet.

Weritworth, 6 to 8 feet

8 to 8 feet.

WEEPING TREES.

Ash-Gold Bark

Beech-Pendula, 4 to 6 feet.

6 to 8 feet...

Birch-Cut-leaved, 4 to 5 feet.

5 to 6 feet.

6 to 8 feet.
Per 10 Per 100

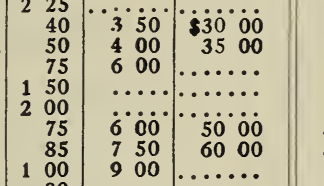

$850 \cdots \cdots$

1000

$\begin{array}{llll}3 & 00 & 25 & 00\end{array}$

$\begin{array}{llll}4 & 00 & 3500\end{array}$

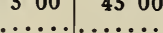

$\because \frac{00}{0}$

$\begin{array}{ll}6 & 00 \\ 6 & 00\end{array}$

4000

$\begin{array}{llllll}5 & 00 & \cdots & 40 & 00 & 0\end{array}$

\begin{tabular}{ll|lll}
6 & 00 & 50 & 00
\end{tabular}

\begin{tabular}{ll|ll}
5 & 00 & 40 & 00
\end{tabular}

$\begin{array}{llll}\mathbf{4} & 00 & \ldots \ldots \ldots \\ 5 & 00 & \ldots \ldots\end{array}$

$\begin{array}{lllll}6 & 00 & \cdots & 50 & 00 \\ 7 & 50 & 60 & 00\end{array}$

$\begin{array}{lllll}7 & 50 & 60 & 00 \\ 9 & 00 & & 75 & 00\end{array}$

$750 \ldots \ldots$

. n

2 $50 \cdots \cdots$

$\begin{array}{lllll}3 & 00 & \cdots & \cdots & 0\end{array}$

$\begin{array}{llll}2 & 50 & 15 & 00 \\ 3 & 50 & 18 & 00\end{array}$

$\begin{array}{llll}4 & 00 & 20 & 00\end{array}$

$350 \quad \ldots \ldots$.

$\begin{array}{llll}4 & 00 & \cdots & \\ 5 & 00 & \cdots & \end{array}$

$600 \quad \cdots \cdots \cdots$

300

250

$250 \quad \ldots \ldots .$.

$350, \ldots \ldots$

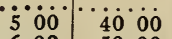

\begin{tabular}{ll|ll}
6 & 00 & 50 & 00
\end{tabular}

\begin{tabular}{ll|lll}
8 & 00 & 65 & 00
\end{tabular}

$\begin{array}{llll}6 & 00 & 6 & \\ 7 & 00 & \ldots \ldots\end{array}$.

$\begin{array}{llll}5 & 00 & \ldots . . .\end{array}$

$\begin{array}{llll}6 & 00 & \ldots \ldots \ldots \\ 3 & 50 & \ldots \ldots\end{array}$

$\begin{array}{ll}3 & 50 \\ 5 & 00\end{array}$

$600 \quad \cdots \cdots \cdots$

400
$40 . \ldots$.

$\begin{aligned} & 5 \\ & 5\end{aligned} 000 . \cdots \cdots$

$\begin{array}{llll}3 & 00 & \ldots \ldots & \\ 4 & 00 & \cdots & \ldots\end{array}$

3
50
4

$400 \quad \cdots \ldots .$.

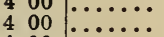

4
5 $0000 \cdots \cdots$

100

100

$\begin{array}{ll}1 & 25 \\ 1 & 50\end{array}$

70

100

$600 \cdots \cdots$

7
7 $50 \quad \cdots \cdots \cdots$ $\because 000 \ldots \ldots$

WEEPING TREES-Con.

Birch-Young's, 3 to 4 feet.

4 to 6 feet.

Cherry-Japan Weeping. 4 to 6 teet.

Cornus Florida Pendula- 4 to 5 feet

Elm-Camperdown Fulva Pendula.

Linden -White-leaf, 4 to 6 ieet.

Mountain Ash.

Mulberry Russian-Tea's New, i year

WillowCurley-leaf, 6 to 8 feet Kilmarnock.....

New American

New American 10 feet.

Thurlow, 8 to 10 feet.

" 8 to 10 leet.

DECIDUOUS SHRUBS.

Almond-Dbl. flowering, Pink and White. Althess -2 to 3 feet

Variegated leaf, 2 to 3 feet.

Azalea-Mollis, 15 to 18 inches.

Barberry-Common and Purple leaved. $11 / 2$ to 2 feet. 2 to 3 feet

Canadensis, 2 to 3 feet.

Thunbergi, $11 / 2$ to 2 feet.

Calycanthus-Floridus, 2 to 3 feet.

Caragana Arborescens -2 to 3 feet.

Cephalanthus Occidentalis-2 to 3 feet

Clethra Alnifolia -2 to 3 feet

Colutea Arborescens- 3 to 4 feet.

Cornus-Elegantissima Variegata, 2 to $3 \mathrm{ft}$

Paniculata..........

Sanguinea, 2 to 3 teet

Sibirica, 2 to 3 feet.

". 3 to 4 feet

Spaethii Aurea, $11 / 2$ to 2 feet.

Currants-Flowering, 2 to 3 feet...

Cydonia Japonica-11/5 to 2 feet.

Doutzia-Assorted, 3 to 4 feet.

Boule de Neige, 2 to 3 feet

Discolor Grandiflora, 2 to 3 feet

Gracilis, 15 to 18 inches.

" Carminea, 2 to 3 feet

Parvifiora, 2 to 3 feet.

Blder-Golden-leaved, 2 to 3 feet.

Cut-leaved, 3 to 4 feet.

Fringe-leaf, 3 to 4 feet...

Eleagnus-Longipes, 2 ito 3 feet

Euonymous Alatus - 2 to 3 feet.

Exochorda-Grandiflora, 3 to 4 feet.

Filbert-Purple-leaved, 2 to 3 feet.

Forsythia-In variety, 2 to 3 feet.

Fringe-Purple, 2 to 3 feet.

Honeysuckle-Alberti 2 to 3 fee Grandiflora, 2 to 3 feet. Morrowi, 2 to 3 feet.

Tartarian Red and White 3 to 4 feet

Virginalis Alba 2 to 3 feet.

Hydrangea-Arborescens Grandifiora$11 / 2$ to 2 feet

2 to 3 feet

Paniculata Grandifiora.

18 to 24 inches.

2 to 3 feet.

Halesia-Tetraptera, 3 to 4 feet.

Kerria-Japonica fl. pl., 2 to 3 feet.

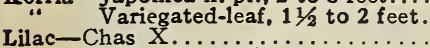

Josikæa, 2 to 3 feet.

New Double Flowered, 8 varieties.

Red, 2 to 3 feet.

“ Pü White

- Rubra de Marley, 2 to 3 feet.

Myrica Cerifera-1 $11 / 2$ to 2 feet....

Philadelphus-(Syringus) 4 varieties, 3 to 4 feet.

Aurea, 15 to 18 inches

Double flowering, 2 to $3 \mathrm{ft}$.

Privet-Amurense, 2 to 3 feet.

California, 2 to 3 feet.

European, 2 to 3 feet.

Ibota, 2 to 3 feet.

Rota, 2 to 3 feet. 3 ............

Prunus-Triloba, 3 to 4 feet.

Pissardi, Purple-leaved, 3 to $4 \mathrm{ft}$.

Rhodotypus Kerrioides -2 to 3 feet ......

Rhus Aromatica-2 to 3 feet

Rhus Glabra -3 to 4 feet...

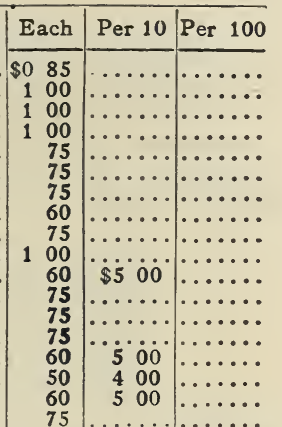

353300

$35 \quad 250$

$\begin{array}{lll}35 & 3 & 00 \\ 25 & 2 & 00 \\ & 5 & 00\end{array}$

$\begin{array}{lll}50 & 5 & 00\end{array}$

\begin{tabular}{r|rr|rr}
15 & 1 & 00 & $\$ 8$ & 00 \\
20 & 1 & 50 & 10 & 00
\end{tabular}

$\begin{array}{llllll}25 & 2 & 00 & 12 & 00\end{array}$

$\begin{array}{llllll}25 & 2 & 00 & 15 & 00 \\ 30 & 2 & 50 & 18 & 00\end{array}$

$25 \quad 200$

$25 \quad 200$

$25 \quad 200$

2552500

$\begin{array}{llll}250 & 2 & 0 & 0 \\ 30 & 4 & 00\end{array}$

$\begin{array}{lll}30 & 2 & 50 \\ 25 & 2 & 00\end{array}$

25

$\begin{array}{lll}2 & 00 \\ 2 & 50\end{array}$

$\ddot{2} 00$

$\begin{array}{ll}2 & 50 \\ 1 & 50\end{array}$

150

200

250

i $50^{\circ}$

200

250

200

$\begin{array}{lll}4 & 00 \\ & 5 & \\ 2 & 50\end{array}$

i 00

$\begin{array}{ll}2 & 00 \\ 2 & 50\end{array}$

250

200

200

200

300

400

$\begin{array}{lll}2 & 00 \\ 3 & 00\end{array}$

$\begin{array}{lll}3 & 00 \\ 5 & 00 & 0\end{array}$

$\begin{array}{ll}5 & 00 \\ 4 & 00\end{array}$

200

200

500

$\begin{array}{lll}3 & 00 \\ 3 & 00 & -1\end{array}$

$\begin{array}{lll}3 & 00 \\ 2 & 50\end{array}$

$\begin{array}{ll}2 & 50 \\ 2 & 00\end{array}$

200

$\begin{array}{ll}3 & 00 \\ 3 & 00\end{array}$

300

120

100

$\begin{array}{ll}1 & 00 \\ 1 & 20\end{array}$

120
180

300

200

200

350

io 00

1500

io 00

$\begin{array}{ll}6 & 00 \\ 8 & 00\end{array}$

800
1000

1600 
DECIDUOUS SHRUBS - Con.

Rhus-Glabra Laciniata, 2 to 3 feet.

$\because$ Typhena-2 to 3 feet...........

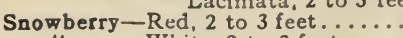
White, 2 to 3 feet

Spireas-In variety, 2 to 3 feet. Anthony Waterer, 15 to $18 \mathrm{in}$.

A:guta, 2 to 3 feet. 18 to 24 in.

Aurea (Golden) 3 to 4 feet

Bumalda, $11 / 2$ to 2 feet.

Callosa Alba, 15 to 18 incli.

Prunifolia, 2 to 3 f eet

Rosea Superba, 2 to $3 \mathrm{fcet}$.

Thunberg's, 15 to 18 inch

Van Houtte. 2 to 3 feet.

Tamarix-In assortment, 3 to 4 fect.

Viburnum-Dentatum, 3 to 4 fect.

Lantana, 2 to 3 feet.

Lentago, 2 to 3 feet.

Opulus, 2 to 3 feet

Plicatum (Japan Snowbail) 2 to 3 feet Sterilis (Snowbail), 2 to $3 \mathrm{ft}$

Weigela-In variety, 2 to 3 feet.

Fol. Variegata, 2 to 3 feet.

Eva Rathke, 2 to 3 feet.

\section{CLIMBING VINES.}

Akebia Quinata.

Ampelopsis-American I $\mathrm{ivy}, 2$ years Engelmanni...............
Veitchii, strong plants

Bignoaia Grandiflora-2 ycar.....

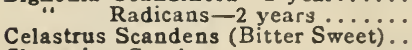
Clematis-Coccinea

Jackmani and other large flowering sorts....

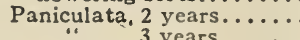

Honeysuckle - In variety ...............

Kudzu Vine. Monthly Fragran
Scarlet Trumpet.

Matrimony Vine.

Wilk Vine - Chinese White

Multijuga

HEDGE PLANTS.

Barberry-Common and Purple-leaved, 15 to 20 inches 15 inches.

“ 15 to 18 inches.

Honey Locust, 15 to 18 in. per $1,000 \$ 6.00$

Osage Orange. 1 year, per $1.000, \$ 2.50$.

Privet-California, 15 to 18 inches.

$$
\begin{aligned}
& \text { European, } 15 \text { to } 18 \text { inches. } \\
& \text { Ibota, } 18 \text { to } 24 \text { inches...... } \\
& \text { ". } 15 \text { to } 18 \text { inches..... }
\end{aligned}
$$

gal's, 15 to 18 inches.

Pyrus Japonica-15 to 18 inches.
Rhammus Catharticus -15 to 18 inches 12 to 15 inches.

\section{ROSES.}

Strong two year field-grown, except noted

Hybrid Perpetual, in fine assortment.

American Beauty.

Soliel de Or.

Moss, fine assortment

Persian and Harrison's Yellow.

Sweet Brier.

Climbing, in variety

Climbing, in var

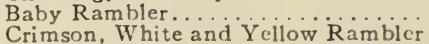

Blue Rambler.

Tea and other tender Everblooming, 4 in pot plants.

Marechal Neil, 4 and 5 inch pot plants..

Tree or Standard.

\section{EVERGREENS.}

All nursery grown, bushy transplanted stock.

If evergreens are balled and burlapped, add 10 cents ach for $11 / 2$ to 2 feet, 12 add 10 cents 2 ach for $13 / 2$ to 2 feet, 12 cents for 2 to 3 feet, 15 cents for
feet, 25 cents for 4 to 5 feet.

Arbor Vitæ-American, 12 to 15 inches. 15 to 18 inches.

Eac

Per 10 'Per 100

$35 \$ \$ 350 \ldots$

35 2 200 \$i

$\begin{array}{rrrrr}25 & 2 & 00 & \$ 15 & 00 \\ 25 & 2 & 00 & 15 & 00\end{array}$

$\begin{array}{lllll}25 & 2 & 00 & 15 \\ 25 & 2 & 00 & \ldots\end{array}$

$\begin{array}{lllll}25 & 2 & 00 & \cdots \cdots \\ 30 & 2 & 50 & \cdots & \cdots\end{array}$

$30 \quad 2 \quad 50$

$\begin{array}{llll}30 & 2 & 50 \\ 25 & 2 & 0 & -1\end{array}$

25 25 03

$30 \quad 250$

$30 \quad 250$

$25 \quad 200$

$\begin{array}{lllll}20 & 1 & 50 & 12 & 00 \\ 25 & 2 & 00 & 15 & 00\end{array}$

$25 \quad 200$

$\begin{array}{llll}25 & 2 & 00 \\ 30 & 2 & 5\end{array}$

$30 \quad 250$

25200

$\begin{array}{lll}35 & 3 & 00\end{array}$

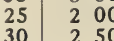

$\begin{array}{lll}35 & 2 & 50 \\ 25 & 00\end{array}$

$\begin{array}{lll}30 & 2 & 50 \\ 35 & 3 & 00\end{array}$

$\begin{array}{ll}2 & 50 \\ 3 & 00\end{array}$

25
20
25
25
35
30
35
25
50
25
35
25
35
35
25
25
30
50
40
25

200

$\begin{array}{lll}1 & 50 \\ 2 & 00 & -10\end{array}$

200

$\begin{array}{lll}3 & 00 \\ & & \end{array}$

$\begin{array}{ll}2 & 50 \\ 3 & 00\end{array}$

200

400

200

$\begin{array}{lll}3 & 00 \\ 2 & 00 & -1\end{array}$

200

\begin{tabular}{|c|c|c|}
\hline 10 & 80 & 600 \\
\hline 15 & 80 & 500 \\
\hline & 100 & $\begin{array}{l}700 \\
1100\end{array}$ \\
\hline 10 & 50 & 300 \\
\hline & 70 & 400 \\
\hline & 60 & -500 \\
\hline 10 & 80 & 600 \\
\hline & 80 & 700 \\
\hline & 60 & 500 \\
\hline & 120 & 1000 \\
\hline & 80 & 600 \\
\hline & 100 & 700 \\
\hline & 80 & 50 \\
\hline
\end{tabular}

200

$\begin{array}{ll}2 & 00 \\ 2 & 50\end{array}$

200

$\ldots \ldots$

$\ldots \ldots$

$\ldots \ldots$
$\ldots \ldots$
$\ldots$
$\ldots \ldots$
$\cdots \cdots$
$\cdots \cdots$
$\cdots$
$\cdots$

$\ldots \ldots$

$\ldots \ldots$

$\ldots \ldots$

- n

....

$\ldots \ldots$$$
\text { Juniper- }
$$

EVERGREENS - Continued.

Arbor Vitæ-American, 18 to 24 inches, $\$ 030$ - 00

2 to 3 feet.....

Compacta, 15 to 18 inches.

" 2 to 3 feet.

Arbor Vitæ-Ellwangerialden, $11 / 2$ to $2 \mathrm{ft}$. Ericoides, 15 t 18 to 2 feet.

Globosa, $11 / 2$ to 2 feet.

Hovey's Golden, $11 / 2$ to $2 \mathrm{ft}$.

Lutea (Geo. Peabody). $11 / 2$ to 2 feet. 2 to 3 feet.

Pumila, $11 / 2$ to 2 feet.

Pyramidalis, $11 / 2$ to 2 feet. 2 to 3 feet

Semper Aurea, $11 / 2$ to 2 feet Siberian, $11 / 2$ to 2 feet

2 to 3 feet.

Tom Thumb, 12 to 15 in.

Vervæneana, 2 to 3 feet.

Cypress-Lawsoniana, 2 to 3 feet.......

Nutkrensis, $11 / 2$ to 2 feet.

Fir Silver-Amer. Balsam, 18 to $24 \mathrm{in}$.

Cephalonica 2 to 3 feet .

Cephalonica, 2 to 3 feet.

18 to 24 inches.

Violaces, 18 to 24 in

European, $11 / 2$ to 2 feet. 2 to 3 feet.

Fraseri, $11 / 2$ to 2 feet.

Nordmans to 3 feet.................... $11 / 2$ to 2 feet.

Elegantissima, $11 / 2$ to 2 feet...

English, 11/2 to 2 feet.............

Excelsa, 2 to 3 fcet.

Irigh. $1 \frac{1}{2}$ to 2 feet.

Japan, 18 to 24 inches.

Neaboriensis, $11 / 2$ to 2 fcet

Savin, 15 to 2 feet.

Savin, 15 to 18 incines.

Swedish. 2 to 3 feet.

24 inches

Virginiana(RedCedar), 11/2to2ft. “" $0 \quad$ Glauca, $11 / 2$ to $2 \mathrm{ft}$. $13 / 2$ to 2 feet

Dwarf, 12 to 15 inches.

Scotch, 18 to 24 inches.

2 to 3 feet.

White, $11 / 2$ to 2 feet.

"“ " 2 to 3 feet. $\ldots$. 24 inches.

Filifera Pendula, 15 to 18 in.

Gracilis Aurea, 18 to 24 in..

Obtusa Nana, 15 to 18 in.

"Gracilis, 15 to 18 in

Plumosa, $11 / 2$ to 2 feet. 2 to 3 feet.

$\because \quad$ Aurea, 15 to 18 in.

18 to 24 in

Spruce-Alcocguiana, $11 / 2$ to 2 feet..... Am. White, 2 to 3 feet.

Colorado, 2 to 3 feet

Blue, 2 to 3 feet.

Blue, 2 to 3 feet.

"Grafted, $11 / 2$ to $2 f$ t.

Douglas, 2 to 3 feet............

Engelmanni, $11 / 2$ to 2 fee

Hemlock, $11 / 2$ to 2 feet.

Norway, 12 to 15 inches.

1.5 to 18 inches.

$11 / 2$ to 2 feet

2 to 3 feet.

Weeping, 2 to 3 fce

Golden 2 to 3 feet.

Polita, 18 to 24 inches.

Yew-Elegantissima، 12 to 15 inches.

\section{EVERGREEN SHRUBS.}

Box-Dwarf, 4 to 6 inches

Tree 10 to 12 inches

Daphne Cneorum- 12 to $15 \mathrm{in}$. bushey.

Euonymous Radicans -8 to 12 inches

Kalmia Latifolia-15 to 18 in.

Mahoaia A quifolia -12 to 15 inches.

$\begin{array}{lll}7 & 00 \\ 9 & 00 & 0\end{array}$

\begin{tabular}{lll|ll}
40 & 3 & 00 & 25 & 00
\end{tabular}

$\begin{array}{llllll}50 & 4 & 00 & \ldots & 4 & 0\end{array}$

90

50

50

40
60

100

150

50
50
75

75
75

50

$60 \quad 500$

\begin{tabular}{l|lll}
40 & 3 & 00 \\
-1
\end{tabular}

75

$\begin{array}{ll}1 & 00 \\ 1 & 00\end{array}$

$\begin{array}{ll}1 & 00 \\ 1 & 25\end{array}$

40

\begin{tabular}{l}
60 \\
125 \\
\hline
\end{tabular}

125

100

$\begin{array}{ll}1 & 25 \\ 50 & 50\end{array}$

60

60
75
75

100

100

$7 \dot{50}$

1000

850

500

600

75
75
100

50

75

75

60
40

350

400

400

500

$\begin{array}{ll}5 & 00 \\ 4 & 00\end{array}$

500

350

400

$\begin{array}{ll}4 & 00 \\ 5 & 00\end{array}$

75
100

60

75
60

$\begin{array}{llllll}3 & 50 & 25 & 00 \\ 5 & 00 & & 35 & 00\end{array}$

...............

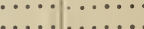

$\ldots \ldots$

$\ldots \ldots \ldots \ldots$ 


\section{Our Special Low-Priced Collections}

, For $\$ 1$

Set No. 56.-Apple trees: 1 each of Yellow Transparent, Maxsons Early, Banana, Baxter, Boiken, Opalescent and Sutton's Beauty.

Set No. 57. -4 Pear trees and 5 Apple trees, all different.

Set No. 58.-2 Cherry trees and 3 Pear trees, all different.

Set No. 59.-2 each: Pear. Plum, Apple, Peach, all different.

Set No. 60.-1 each: Baxter and Opalescent Applies, Monarch Plum, Rossney Pear, Campbell's Early and Diamond Grapes.

Set No. 61.-Japan Plums, 1 each: Santa Rosa, Maynard, Shiro and Chabot.

Set No. 62.-1 each: Admiral Dewey Peach, Worden Seckel Pear, Fellenburg Prune, Red Astrachan Apple and Woodruff Graje.

Set No. 63.-2 each of Wyoming, Concord, Diamond, Niagara, Worcien and Pocklington Grape-vines.

Set No. 64.-15 Concord Grape-vines; or 13, our choice, in 4 rarieties.

Set No. 65.-1 each: Campbell's Early, Pocklington, Woodruff, Regal, Green Mountain and Moore's Early Grape-rines.

Set No. 66. -42 Raspberries, 7 each: Kansas, Gregg, Cumberland, Marlboro, Cuthbert and Columbian.

Set No. 67.-25 Raspberries, 5 each: King, Haymaker, Columbian, Cumberland, Ruby; and 5 Lucretia Dewberries.

Set No. 68.-60 Raspberries, 4 sorts, our choice.

Set No. 69.-20 Currants, 5 each: Victoria, Cherry, Fay's Prolific and White Grape.

Set No. 72.-2 Grape-vines, 2 Currants, 5 Raspberries, 5 Blackberries and 2 Gooseberries.

Set No. 73.-. Japan Walnuts, 1 Hickory, 1 Filbert.

Set No. 74.-30 Sweet, 1 Japan and 1 Spanish Chestnuts.

Set No. 75.-11 Gooseberries: 5 Downing, 5 Houghton and 1 Industry.

Set No. 76. - 10 Lucretia Dewberries; and 20 Blackberries, 5) each: Ward, Taylor, Mersereau and Eldorado.

Set No. 77.-24 Hyacinths in separate colors for indoor or winter-blooming.

Set No. 78.-24 Hyacinths in separate colors, for outdoor blooming.
Set No. 79.-75 mixed early single Tulips.

Set No. 80.-75 mixed early double Tulips.

Set No. 81.-12 Hyacinths, different colors; 20 Tulips, good assortment?; 10 Enowdrops and 10 Crocus.

Set No. 82.-8 Hyacinths, 10 Tulips, 4 Narcissus, 10 Crocus, 6 Scilla Sibirica, 6 Oxalis.

Set No. 83.-2 Lilium Harrisii, 2 Lilium Candidum, 2 Roman Hyacinths, 2 Paper-IVhite Narcissus, 6 Freesia Refracta Alba, 6 Early-flowering Tulips, 10 Crocus, 6 Glory-of-the-Snow.

Set No. 84.-2 Calla Ethiopica, 4 Lilium Harrisii, 6 Freesia, 2 Chinese Narcissus, 2 Paper-White Narcissus, 4 Glory-of-the-Snow.

Set No. 85.-16 Beautiful Ever-blooming Roses, 16 different sorts, all named.

Set No. 86.-6 Palms, strong plants, 8 to 10 inches high.

Set No. 87.-12 Hardy Herbaceous Plants, 12 sorts.

Set No. 88.-4 Begonias, 4 Ferns, 6 Roses.

Set No. 89.-8 Roses and 6 Begonias, winter flowering, different sorts.

Set No. 90.-2 Palms (2 sorts), 4 Begonias, 4 Roses, 2 Dracenas.

Set No. 91.-2 Primroses, 2 Chrysanthemums, 2 Ferns, 2 Roses, 2 Begonias, 2 Asparagus Plumosus.

\section{One-half of any of the above Collections- Nos. 77 to 91 -for 50 cents.}

\section{2.}

Set No. 92.-Choice Foliage Plants: 1 Croton, 1 Fern, 1 Palm, 1 Ficus, 1 Dracena, 1 Asparagus Plumosus, 1 Begonia, 1 Sansevera, 1 Carex Variegata.

Set No. 93.-6 Roses, 2 Asparagus Plumosus Nanus, 6 Begonias.

Set No. 94.-4 Roses, 3 Begonias, 2 Primroses, 1 Calla, 1 Asparagus Sprengeri, 1 Boston Fern, 1 Dracena.

Set No. 95.-1 Rose, 1 Carnation, 1 Calla, 1 Begonia, 1 Asparagus Sprengeri, 1 Abutilon, 1 Primrose, 1 Asparagus Plumosus, 1 Palm, 1 Fern, 1 Bougainvillea.

Set No. 96.-1 Palm, 1 Rose, 1 Maiden Hair Fern, 1 Carnaticn, 1 Bougainvillea, 1 Pteris Tremula Fern, 1 Begonia, 1 Primrose, 1 Calla, 1 Asparagus Sprengeri, 1 Boston Fern.

Set No. 97.-1 Fern, 1 Primrose, 1 Carnation, 1 Calla, 1 Grevillea Robusta, 1 Begonia, 1 PaIm, 1 Baby Rambler Rose.

Set No. 98. -6 Peonies, 6 varieties.

Set No. 99.-12 Hardy Shrubs, 12 varieties. 

THE STORRS \& HARRISON CO., Painesville,

Nurserymen, Florists and Seedsmen. Lake County, OHIO. 


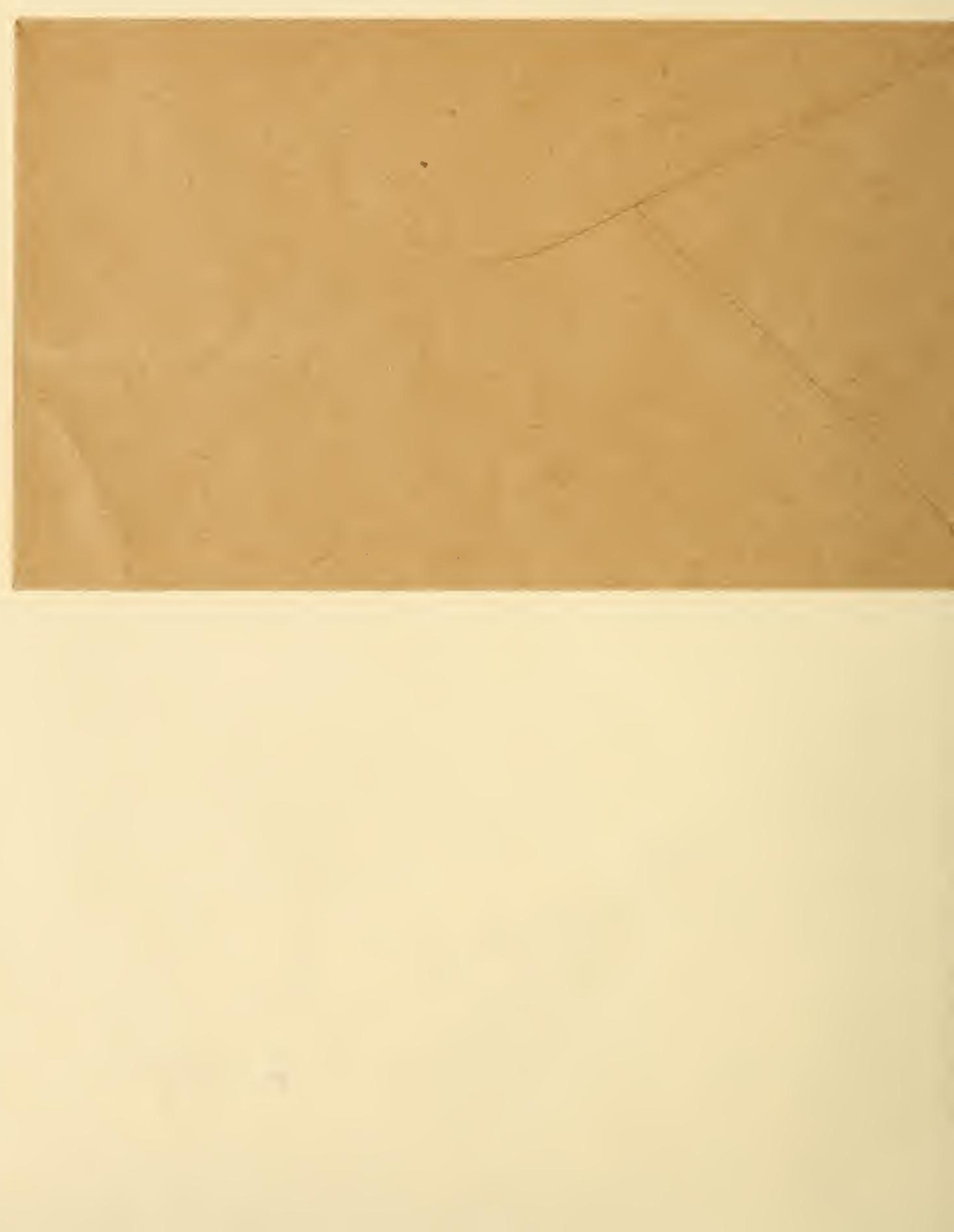





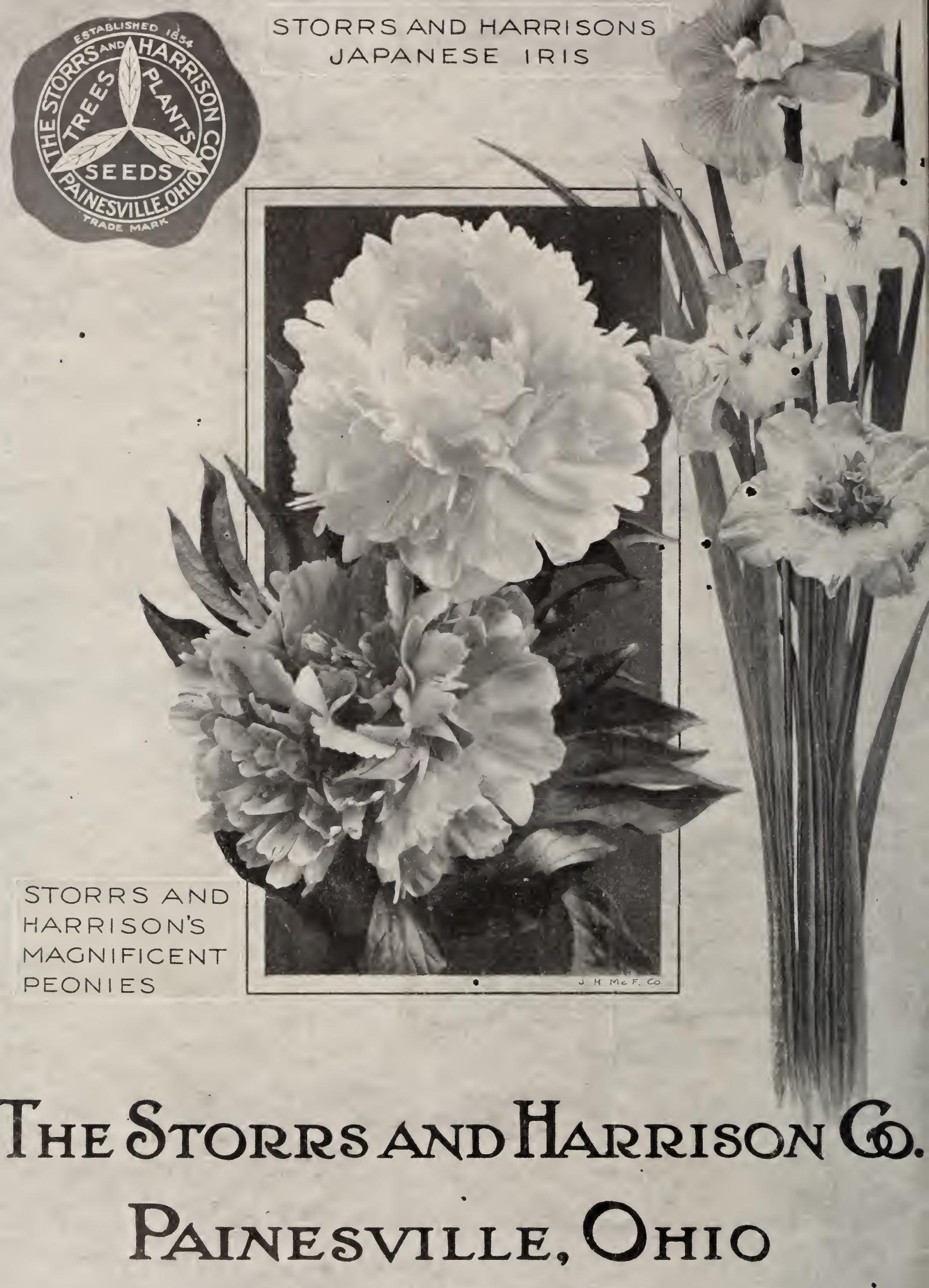

